\title{
The Alamo Restoration and Conservation Project: Excavations at the South Transept
}

Barbara A. Meissner

Center for Archaeological Research

Follow this and additional works at: https://scholarworks.sfasu.edu/ita

Part of the American Material Culture Commons, Archaeological Anthropology Commons, Environmental Studies Commons, Other American Studies Commons, Other Arts and Humanities Commons, Other History of Art, Architecture, and Archaeology Commons, and the United States History Commons

Tell us how this article helped you.

This Article is brought to you for free and open access by the Center for Regional Heritage Research at SFA ScholarWorks. It has been accepted for inclusion in Index of Texas Archaeology: Open Access Gray Literature from the Lone Star State by an authorized editor of SFA ScholarWorks. For more information, please contact cdsscholarworks@sfasu.edu. 
The Alamo Restoration and Conservation Project: Excavations at the South

Transept

Creative Commons License

(c) (i) (8)

This work is licensed under a Creative Commons Attribution-NonCommercial 4.0 International License 


\section{The Alamo Restoration}

and Conservation Project:

Excavations at the South $V_{\text {ransept }}$

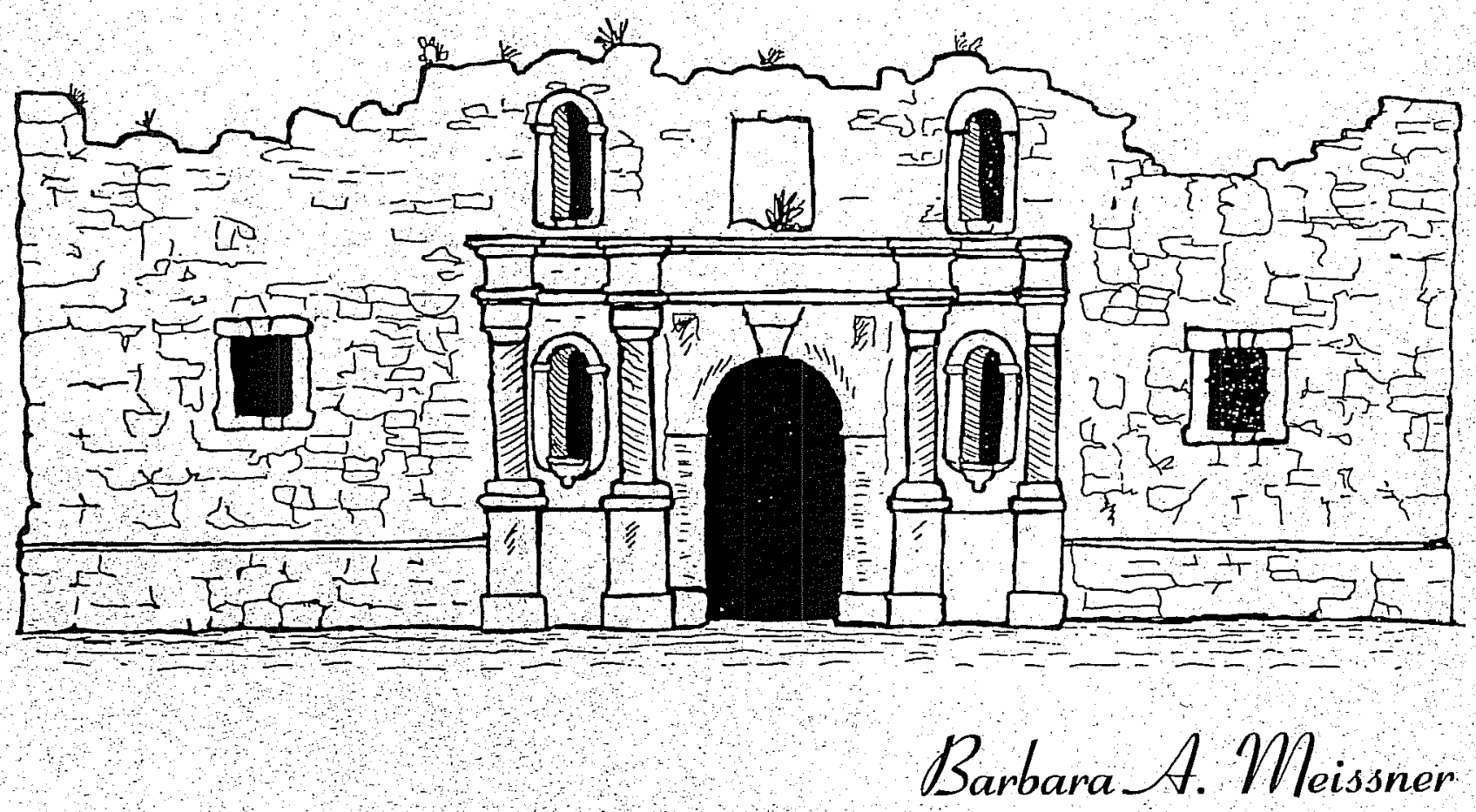

with a Contribution by Paul Goldberg

Center for Archaeological Research The University of Jexas at San Antonio Archaeological Survey Report, $\eta_{o}, 245$ 



\title{
The Alamo Restoration and Conservation Project: Excavations at the South Transept
}

\author{
Barbara A. Meissner \\ with a Contribution by Paul Goldberg
}

Robert J. Hard and C. Britt Bousman

Principal Investigators

Texas Antiquities Committee Permit No. 1503

Center for Archaeological Research The University of Texas at San Antonio Archaeological Survey Report, No. 245 
The following information is provided in accordance with the General Rules of Practice and Procedure, Chapter 41.11 (Investigative Reports), Texas Antiquities Committee:

1. Type of investigation: Excavation

2. Project name: Alamo South Transept

3. County: Bexar

4. Principal investigators: Robert J. Hard and C. Britt Bousman

5. Name and location of sponsoring agency: Daughters of the Republic of Texas, The Alamo, San Antonio, Texas

6. Texas Antiquities Committee Permit No.: 1503

7. Published by the Center for Archaeological Research, The University of Texas at San Antonio, San Antonio, Texas 78249-0658, 1996.

A list of publications offered by the Center for Archaeological Research is available. Call (210) $458-4378$ or write to the Center for Archaeological Research, The University of Texas at San Antonio, 6900 N. Loop 1604 West, San Antonio, Texas 78249-0658. 


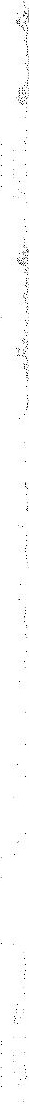




\section{Abstract}

Tn January 1995, the Daughters of the Republic of Texas, as custodians of the Alamo Shrine for the state of Texas, contracted with the Center for Archaeological Research of The University of Texas at San Antonio to - 1 excavate and/or monitor excavation of approximately 29 square meters outside and 11 square meters inside the south wall of the south transept of the Alamo church. The excavations were made necessary by a plan to insert metal plates into the walls of the Alamo near the foundation, to prevent further damage being caused by groundwater in the lower part of the walls of the 250 -year-old building.

Excavations in January and February 1995 determined that artifacts inside the church were largely of nineteenth century origin; however, in one area numerous Colonial-period artifacts were found. The sediment inside the church, under the flagstone floor, was found to be broken stone rubble mixed with loose sandy clay. Exterior sediments from the ground surface to the top of the foundation, approximately $60 \mathrm{~cm}$ below ground surface, were severely disturbed. One $10-\mathrm{cm}$ level east of the south transept appears to be an intact nineteenth-century level. Most dateable artifacts from the exterior can be assigned to the late-nineteenth and early twentieth centuries.

On the final day of excavations, the sediments at the bottom of the excavations inside the church collapsed in three places. What appeared to be human remains were seen in two of these openings, approximately $20 \mathrm{~cm}$ below the lowest excavated level. These holes were backfilled and no further investigation of the remains was attempted. 


\section{Contents}

Abstract $\ldots \ldots \ldots \ldots \ldots \ldots \ldots \ldots \ldots \ldots \ldots \ldots \ldots \ldots \ldots \ldots \ldots \ldots \ldots \ldots \ldots$

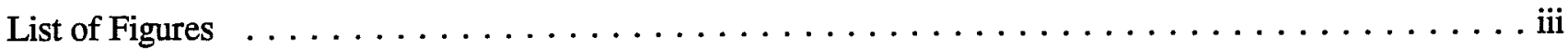

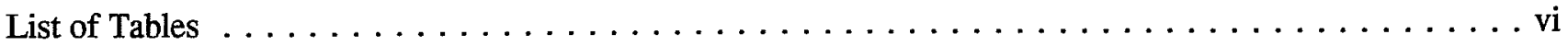

Acknowledgments $\ldots \ldots \ldots \ldots \ldots \ldots \ldots \ldots \ldots \ldots \ldots \ldots \ldots \ldots \ldots \ldots$ vii

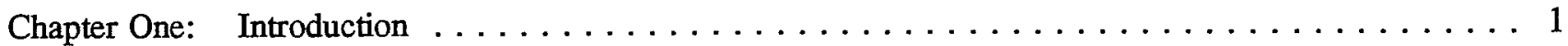

Chapter Two: History of the Alamo $\ldots \ldots \ldots \ldots \ldots \ldots \ldots \ldots \ldots \ldots \ldots \ldots \ldots \ldots \ldots \ldots$

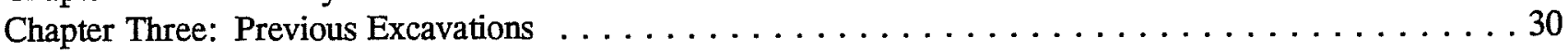

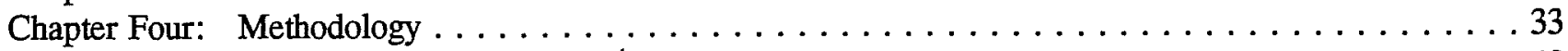

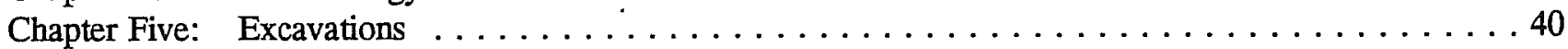

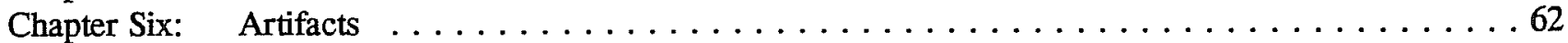

Chapter Seven: Faunal Analysis . . . . . . . . . . . . . . . . . . . . . . . 95

Chapter Eight: Summary and Recommendations . . . . . . . . . . . . . . . . . . . 101

References Cited . . . . . . . . . . . . . . . . . . . . . . . . . . . . . . . . . 104

Appendix A. Micromorphological Analysis of Selected Samples from the Alamo

Paul Goldberg, Micromorphology Unlimited . . . . . . . . . . . . . . . . . . . 115

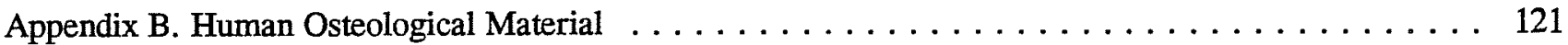

Appendix C. Complete Provenienced Artifact Tables . . . . . . . . . . . . . . . . . 123 


\section{Figures}

1. Close-up of damage to walls of the south transept due to "rising damp." $\ldots \ldots \ldots \ldots \ldots \ldots$

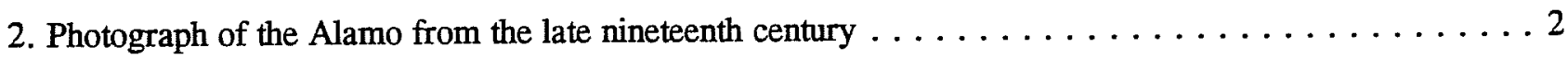

3. The Alamo Shrine, after the 1995 restoration of the facade, May $1995 \ldots \ldots \ldots \ldots \ldots$

4. Portion of a map of the five missions on the San Antonio River. . . . . . . . . . . . 7

5. Native American population changes at Valero . . . . . . . . . . . . . . . . 9

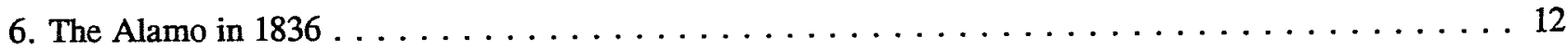

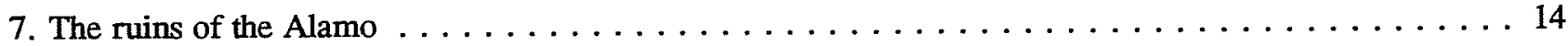

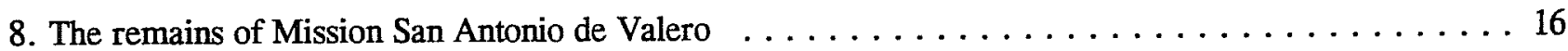

9. The front of the Alamo after repairs by the U.S. Army, 1870 s . . . . . . . . . . . . 17

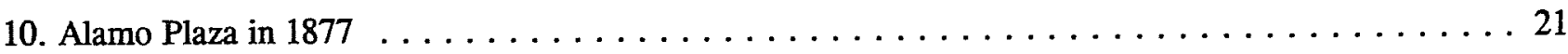

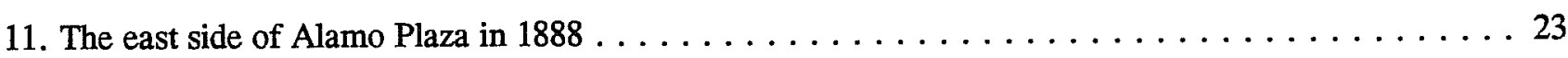

12. Photograph of Alamo Plaza in the 1880 s, showing police station . . . . . . . . . . . . 24

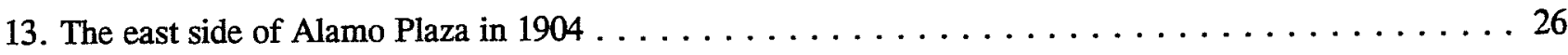

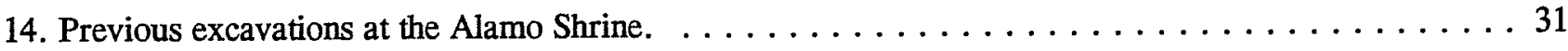

15. Plan view of the Alamo, showing areas to be excavated. $\ldots \ldots \ldots \ldots \ldots \ldots \ldots \ldots \ldots \ldots \ldots \ldots$

16. Area of exterior excavations before project, looking west $\ldots \ldots \ldots \ldots \ldots \ldots \ldots \ldots \ldots \ldots \ldots \ldots$

17. Location of test units in exterior excavations. . . . . . . . . . . . . . . . 34

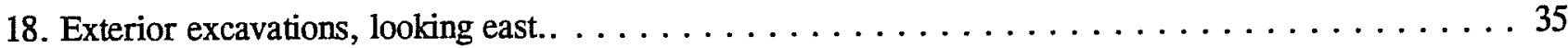

19. Photo of exterior excavations taken from the roof of the Alamo, looking southeast . . . . . . . 35

20. Diagram of Area B, north of the concrete foundation, and monitored excavation extensions. . . . . 36

21. Workers removing the floor on the interior of the south transept. . . . . . . . . . . 37

22. Interior excavation area, showing ground surface after removal of concrete slab. . . . . . . . 38

23. Diagram of interior excavation units. . . . . . . . . . . . . . . . . . . . . 39

24. Schematic section through wall of Unit $101 \mathrm{~N} / 95 \mathrm{E}$, looking west $\ldots \ldots \ldots \ldots \ldots$

25. Profile of east wall of Unit $99 \mathrm{~N} / 100 \mathrm{E}$ extended to the south wall of the Alamo. . . . . . . . . . 41

26. The bottom of Unit $100 \mathrm{~N} / 93 \mathrm{E}$, showing the foundation of the Alamo . . . . . . . . . . . 42

27. Area A, looking east, with rubble foundation shown on the right side. . . . . . . . . . 43

28. Cedar post set into foundation of southeast corner of the south transept, looking north $\ldots \ldots \ldots 5$ 
29. Profile of north wall of Area A. . . . . . . . . . . . . . . . . . . 44

30. Concrete foundation at the eastern corner of the south transept, Area B, during excavation. . . . . 45

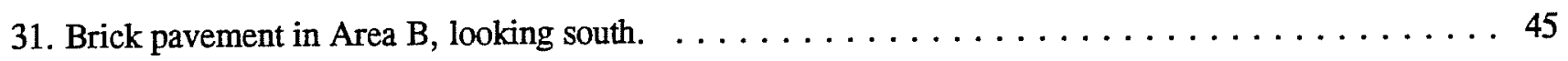

32. Area $B$, looking north, showing concrete foundation and brick pavement. . . . . . . . . 46

33. Schematic diagram of exterior excavations showing all encountered pipes. . . . . . . . . . 46

34. CAR personnel clearing bottom of exterior excavation, looking west $\ldots \ldots \ldots \ldots \ldots$

35. Caliche surface at west end of Area $C$, looking east. $\ldots \ldots \ldots \ldots \ldots \ldots \ldots \ldots \ldots$

36. Drawing of the exterior lower walls of the south transept, above the foundation stones. . . . . . . 48

37. Caliche surface and Alamo foundation stones at the west corner of the south transept. . . . . . . . . 49

38. Alamo foundation stones at the center of the south transept. . . . . . . . . . . . . . . 49

39. Alamo foundation near eastern edge of south transept. . . . . . . . . . . . . . . 50

40. Diagram of uneven foundation stone elevations, taken 21 locations along south wall $\ldots \ldots \ldots 50$

41. Plan view drawing of complete exterior excavations. $\ldots \ldots \ldots \ldots \ldots \ldots \ldots \ldots \ldots \ldots \ldots \ldots \ldots$

42. Portion of concrete foundation in a wheelbarrow, during removal, showing cut face.. . . . . . 52

43. Photograph of southeast corner of Alamo church $\ldots \ldots \ldots \ldots \ldots \ldots \ldots \ldots$

44. Profile of the east and west walls of the completed exterior excavation . . . . . . . . . . . 54

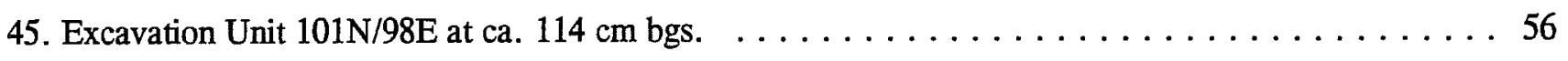

46. Plan drawing of Units $101 \mathrm{~N} / 97-98 E$, at ca. $124 \mathrm{~cm}$ bgs $\ldots \ldots \ldots \ldots \ldots \ldots \ldots \ldots$

47. Unit $100 \mathrm{~N} / 100 \mathrm{E}$ in the western corner of the interior excavations at $114 \mathrm{~cm} \mathrm{bd} \ldots \ldots \ldots$

48. Asphalt-like material in the alcove, with a layer of white mineral salt crystals on its lower surface ... 58

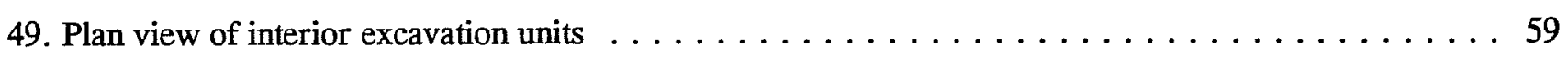

50. Interior wall profile with plan view of threshold of filled-in door $\ldots \ldots \ldots \ldots$. . . . . . 60

51. Profile of north wall of interior excavations. . . . . . . . . . . . . . . . 60

52. Mended chocolateras from exterior excavations. . . . . . . . . . . . . . . 66

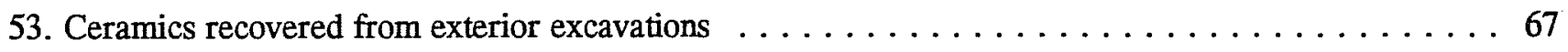

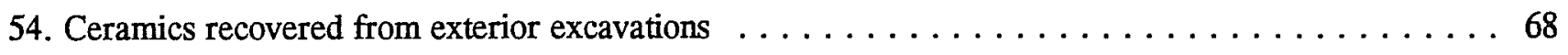

55. Ceramics from exterior excavations. . . . . . . . . . . . . . . . . . . . . . . . . 69

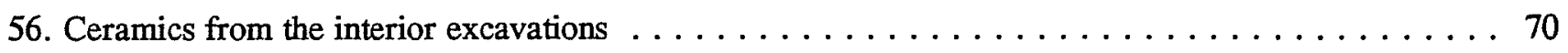

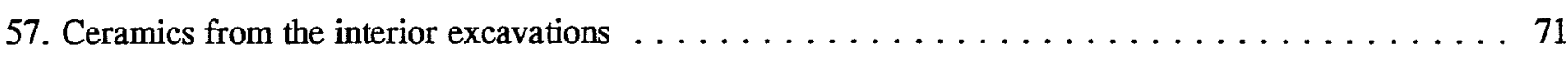

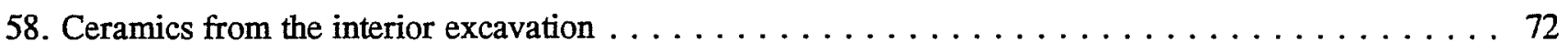

59. Davenport maker's mark. . . . . . . . . . . . . . . . . . . . . . . . . 72

60. Glass from Area B. . . . . . . . . . . . . . . . . . . . 76

61. A bottle fragment with mortar-and-pestle design. . . . . . . . . . . . . . . . . . 77

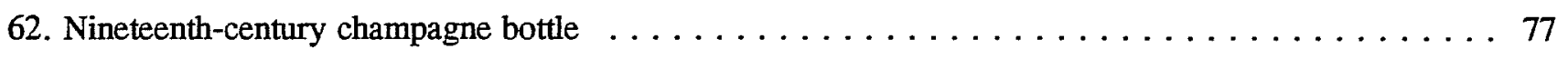

63. Clear "Santal de Midy" bottle. . . . . . . . . . . . . . . . . . . . . . 78

64. Diagnostic glass from the exterior excavation $\ldots \ldots \ldots \ldots \ldots \ldots \ldots \ldots \ldots \ldots$

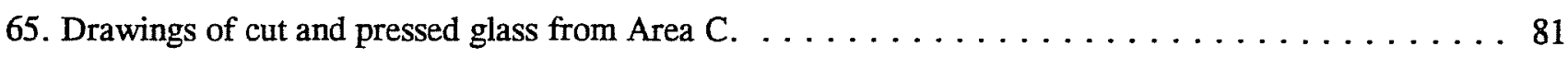


66. Sanford ink bottle fragment.

67. Early nineteenth-century bottles from monitored

68. Brown glass bottle top with copper wire still atached

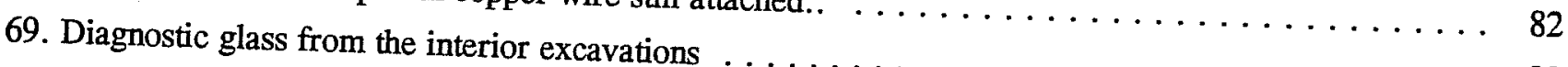

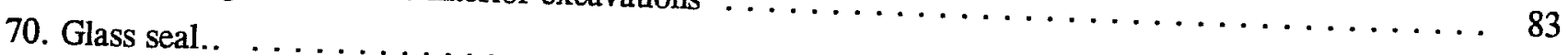

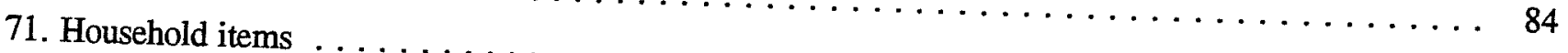

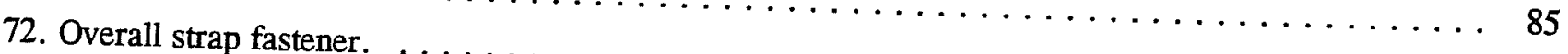

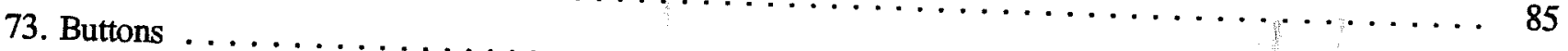

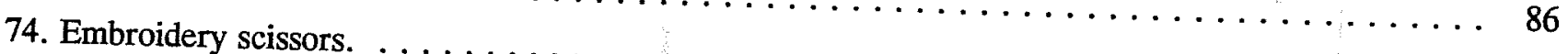

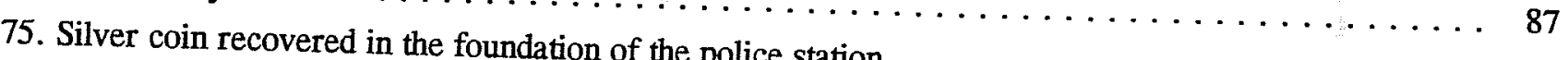

76. Ceramic pipe fragments $\ldots \ldots \ldots \ldots \ldots \ldots$

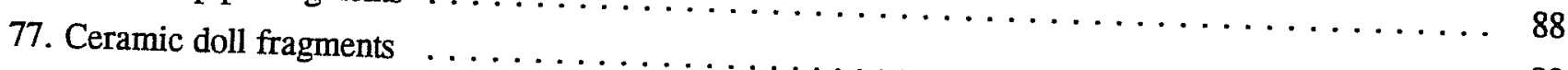

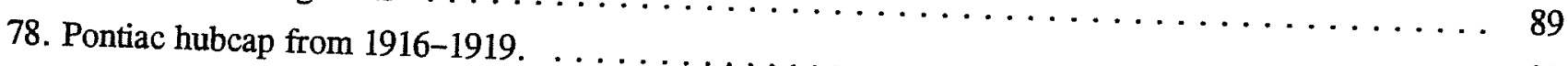

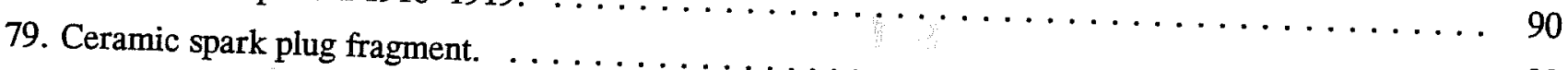

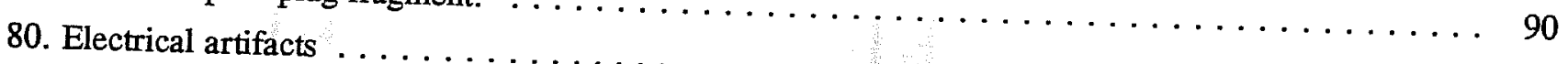

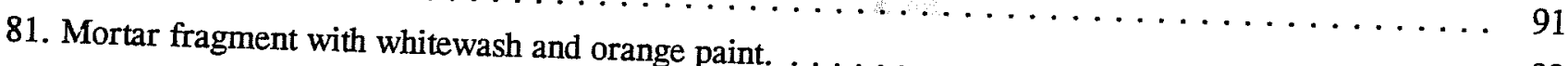

82. Comparison of depth of caliche layer in Eaton $(1980.52)$ and $\ldots \ldots \ldots \ldots \ldots \ldots$

and current project $\ldots \ldots \ldots \ldots 10 \ldots$

A2. Same as Figure A1, photographed in CPL flamo . . . . . . 116

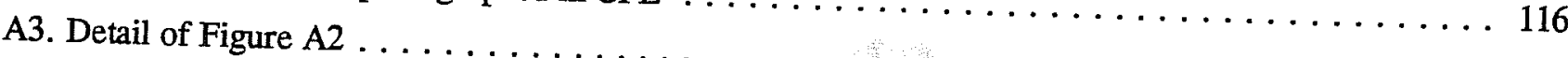

A4. Micro-photo of thin section of sediment sample from the facade of $\ldots \ldots \ldots \ldots \ldots \ldots \ldots$

A5. Same as Figure A4, photographed in CPL $\ldots \ldots 118$

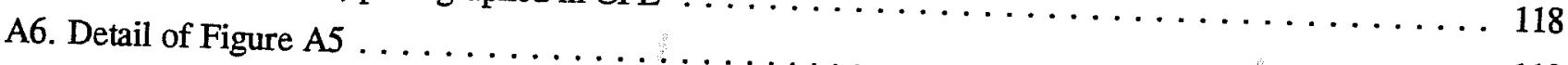




\section{Tables}

28

1. Chronology of Major Events Which Directly Impacted the Alamo . . . . . . . . . 73

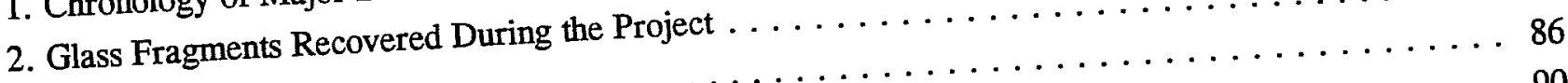

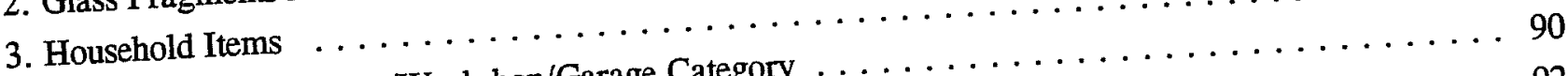

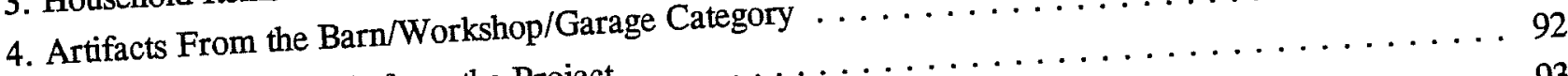

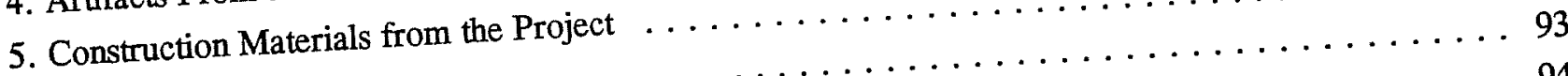

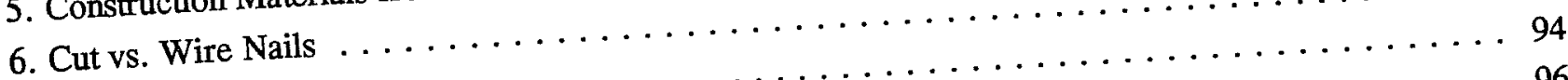

7. Lithic Materials . . . . . . . . . . . . . . . . . . . . . 96

8. Taxa Identified During Analysis . . . . . . . . . . . . . . . 97

9. Summary of Bone Recovered in Exterior Excavations $\ldots \ldots \ldots \ldots \ldots \ldots \ldots \ldots$

10. Summary of Bone Recovered in Interior Units $\ldots \ldots \ldots \ldots \ldots$. 100

11. Comparison of Selected Faunal Material from Mission San Jose and the Alano $\ldots \ldots \ldots \ldots \ldots . \ldots 122$

B1. Human Osteological Material Recovered from Interior Excavations 


\title{
Acknowledgments
}

\begin{abstract}
A ny archaeological project is the work of many individuals. This project was sponsored by the Daughters $\triangle$ of the Republic of Texas (DRT), who were extremely cooperative in allowing access to the Shrine, and in many other ways, including the loaning of lighting equipment and the use of phones. All Alamo Shrine personnel were friendly, cooperative, and helpful. Special thanks are extended to Gail Loving Barnes, then president-general of the DRT; Virginia Nicholas, chair of the Alamo Committee of the DRT; Wallace Saage, then curator of the Alamo; James Pandzik, then business manager of the Alamo; Cathy Herpich, director of the DRT Library, and her staff; Dorothy Black, Alamo Chapel hostess; and Bill Miller, horticulturalist of the Alamo. Carolyn Peterson, architect with Ford, Powell, and Carson, supervised the restoration project, and worked closely with the CAR crew. Curtis Hunt, masonry contractor, and his crew were also very helpful to the project.
\end{abstract}

The co-principle investigators on this project were Robert J. Hard and C. Britt Bousman. Crew members for the project were Barbara A. Meissner (Project Archaeologist), Sandra Billingsley, Kathy Brown, I. Waynne Cox, Jeff Durst, Kevin Gross, H. Curt Harrell, Edgar Johnson, Lynden Kosub, Robert Rector, Andrew Scease, and Cynthia Tennis. Students from UTSA working on independent study courses at the dig were Connie Gibson, Joyce Lomas, and Stephanie Snyder. Lab crew included Connie Gibson, Johanna Hunziker, and student volunteer Stephanie Snyder. Interns Laura Burgess and Aric Kertis helped with monitoring of the later excavations. The author is very grateful to Marcie Renner, CAR editor, for her excellent work and her patience.

A special thanks is given to Dr. Karin Wiltshke, of the National Museum of Austria, Vienna, for her important assistance in identifying human osteological material. Roger Huckabee of Medlar's cleaned and identified the silver coin. Marcie Branson, director of advertising/marketing, Tom Parker, and Bob Hoffstad of Red McComb's Superior Pontiac helped identify a hubcap.

Maps were drafted by Bruce R. Moses and Barbara A. Meissner. Robert R. Rector made the field drawings. Bruce R. Moses drew the artifact illustrations. Maureen J. Brown assisted with artifact photography. René Muñoz assisted in identification of the glass, and Laura Burgess helped identify some other artifacts. Dora Guerra, librarian for the Special Collections at John Peace Library, UTSA, was very helpful during archival research.

The author is especially grateful to Anne A. Fox and I. Waynne Cox. During lab work and write-up, Anne Fox's expertise on Colonial sites in general and Colonial ceramics in particular was invaluable, as was her constant support and friendship. Waynne Cox provided essential assistance in the discovery of archival material, especially information about the police station and the story of Antonio de Tello, as well as other information concerning the history of the Alamo. This report would be far poorer without their efforts and support. 


\section{.}

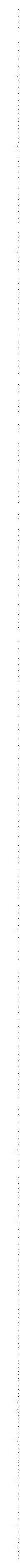

.

t 


\section{Chapter One}

\section{Introduction}

$\mathrm{T}$

The Alamo church, unique in Texas and world history, has withstood 250 years of use, neglect, fire, scorching South Texas summers, turbulent storms, and violent battles. Today, however, the church is slowly disintegrating. The problem is one common to old stone buildings: ground water is absorbed into the soft limestone walls, a situation called "rising damp" (Dabney Group 1985:1). The water carries with it dissolved mineral salts of various kinds which percolate through the walls. When the water reaches the surface of the limestone above ground level, it evaporates, leaving the minerals behind to crystallize on and just beneath the surface of the limestone. The growing crystals eventually push a thin layer of stone off the exposed surface, and the whole process begins again (Dabney Group 1985:16-19). The walls of the Alamo are exfoliating, one flake at a time (Figure 1).

How long this process has been active is unknown, but photographs of the building taken before the turn of the century show a dark stain along the lower quarter of the building (Figure 2; see also Fox et al. 1976:Figures 8a and 9a). This is very similar to modern pictures which record the excess moisture in the walls.

Damage is reaching serious proportions, and the Daughters of the Republic of Texas (DRT) have been trying to find a solution to the problem for many years. A 1979 DRT Master Plan (on file at the DRT Library, the Alamo, San Antonio, Texas) recommended study by a stone preservation specialist. Consequently, chemical and petrographic studies of the walls, including the limestone itself and the mortar, were undertaken in 1984. The recommendations made at that time included removal of the sprinkler system; repair of door, window, and roof seals; and continued monitoring of the problem (Dabney Group 1985:24). It is not surprising that, since the problem is likely to be a pre-twentieth-

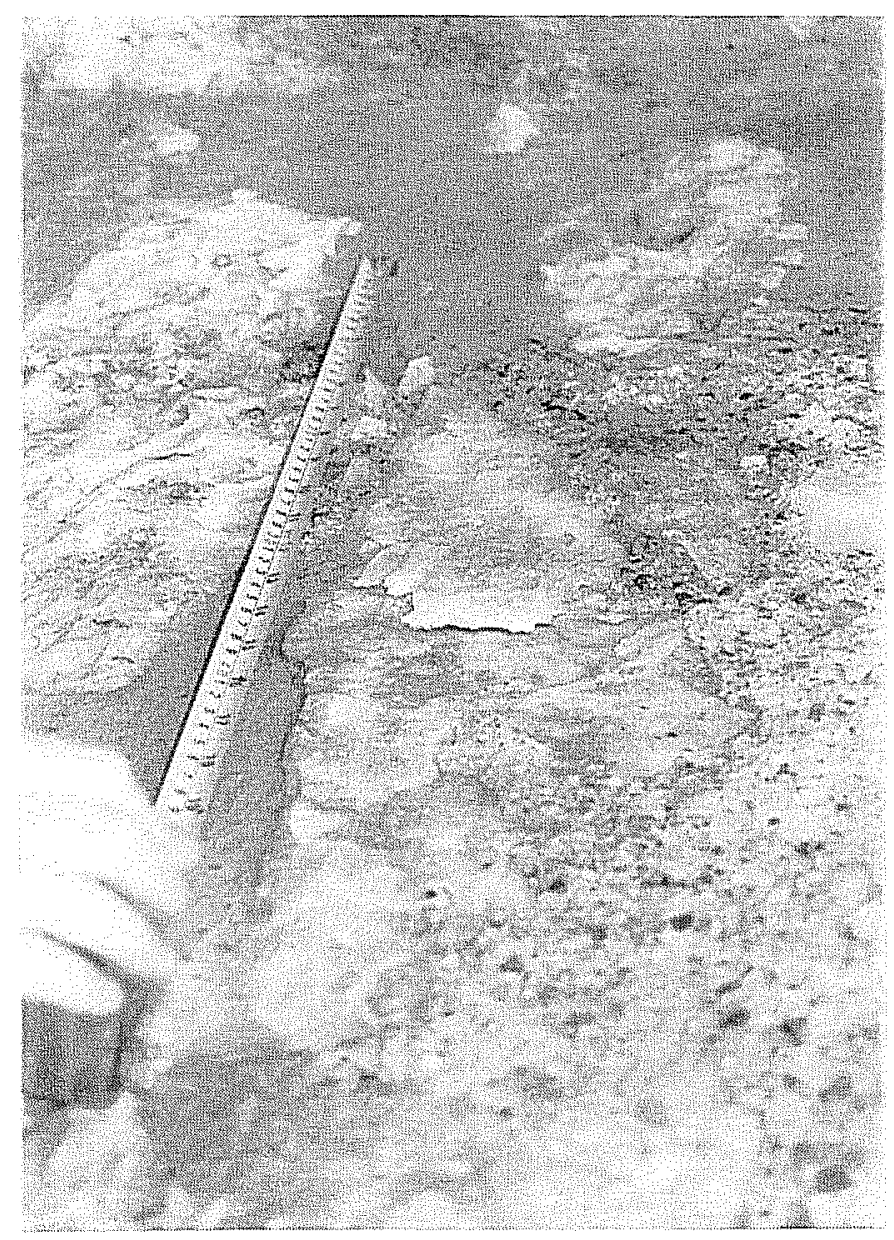

Figure 1. Close-up of damage to walls of the south transept due to "ising damp." 


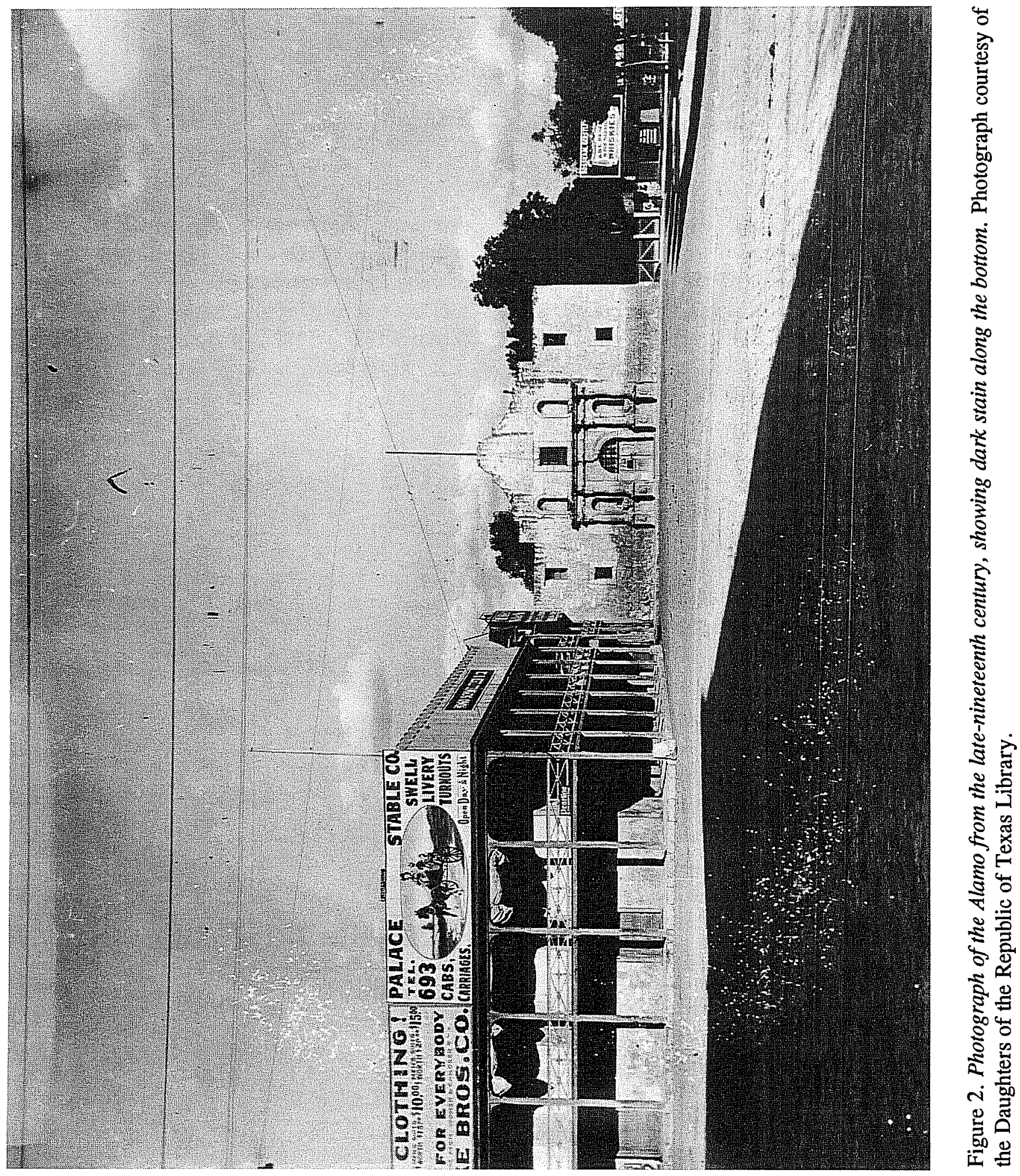


century phenomenon, merely ceasing to spray water around the building did not stop the deterioration.

In December 1994, the DRT accepted a plan by Carolyn Peterson of Ford, Powell and Carson for arresting the deterioration. This plan involved placing a physical barrier of metal through the stone foundation at a point below the ground surface. This would prevent the rise of water into the upper walls of the building. In order to insert the stainless steel sheet, a wire saw would be used to cut through the stone just beneath the upper edge of the foundation. The metal plates could then be inserted into the base of the wall to prevent water moving into the upper walls of the building. Moisture barriers above the metal plate would inhibit water seeping into the wall from the sides. The south transept of the Alamo was chosen as a test of this technique (Carolyn Peterson, personal communication 1995). The ground had to be removed from the walls down to the top of the foundation, leaving enough room for workers to make their saw cuts and to insert the four-foot-wide metal sheets. If this test shows that the technique is successful, the entire building will be treated in a similar fashion.

Previous excavations at the front of the Alamo (Eaton 1980) suggested that the top of the foundation was 60-65 $\mathrm{cm}$ below the current ground surface on the exterior and about the same depth below the floor surface on the interior. The Alamo is owned by the state, so before any activities which may disturb intact cultural deposits are contemplated, steps must be taken to insure that all impacts are limited and information not lost. Since the conservation project proposed digging below ground level to reach the foundations, the Texas Historical Commission (THC) decided that archaeologists would have to either excavate or monitor shovel digging of the necessary trenches.

In January 1995, after completion of plans for the conservation and restoration, the DRT contracted with the Center for Archaeological Research of The University of Texas at San Antonio to excavate and/or monitor excavation of approximately 29 square meters outside and 11 square meters inside the south wall of the south transept of the Alamo Chapel, to a depth 2-3 cm below the upper edge of the foundation. These excavations, which included the first archaeological excavations undertaken inside the structure, were carried out in January and February 1995. 


\section{Chapter Two}

\section{History of The Alamo}

$\mathrm{T}$ The Alamo Shrine (Figure 3), the church of the Mission San Antonio de Valero, has a long and rich history. It was intended to function as the mission chapel, but did so only in a limited fashion for a few years. However, the building has been used in many other ways: military garrison, hospital, fortress, children's playground, military quartermaster's warehouse, grocery store warehouse, police station, and finally as a shrine to those who died there during the Texas Revolution.

Although best known for the famous battle which took place there in February and March 1836, the Alamo represents virtually all the history of Texas: Spanish missions, Mexican independence, Texas revolution,

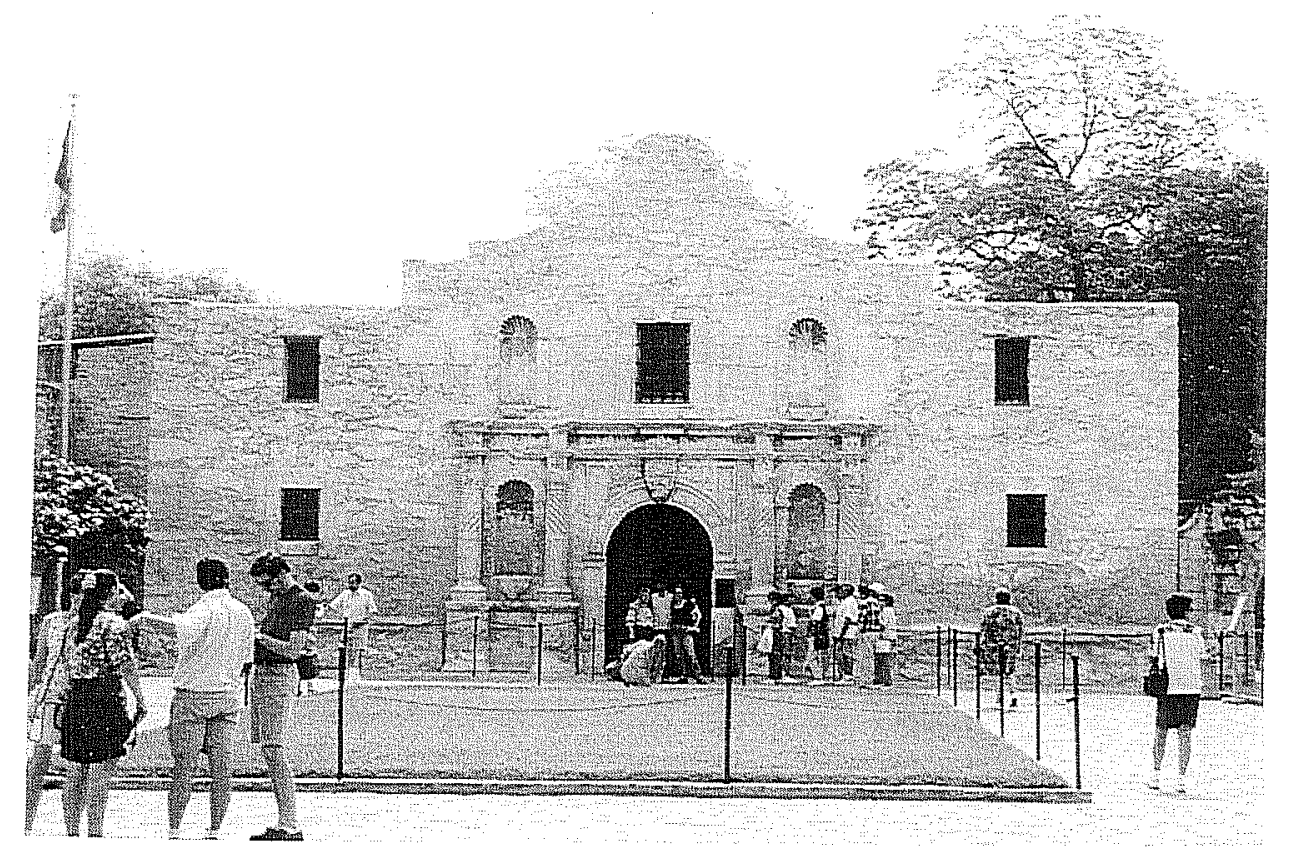

Figure 3. The Alamo Shrine, after the 1995 restoration of the facade, May 1995.
Texas statehood, the Confederacy, Reconstruction, the urbanization of San Antonio, and finally the recognition of the importance of remembering our past. The Alamo church has had a part to playsometimes central, sometimes peripheral-in many major events in the history of the state.

\section{Prehistoric Period (ca. 9200 B.C.-ca. A.D. 1700)}

A detailed discussion of the prehistory of the region immediately around San Antonio is beyond the scope of this report. The interested reader can find an excellent overview of Texas archaeology in Volume 66 of the Bulletin of the Texas Archaeological Society (Pertulla and Reese 1995). More regional material can be found in Black and McGraw (1985), Hester et al. (1989), and Johnson and Goode (1994). A brief outline is presented here.

The vicinity of San Antonio is an area that was, and is, extremely rich in biological and mineralogical resources. The Edwards Plateau, just north of the city, and especially the Balcones Escarpment which cuts across northern Bexar 
County, is an extremely rich source of high-quality chert. Due to the meeting of three major biotic provinces in the county, the area has an unusually high diversity of plants and animals. The three major biotic provinces are the Balconian, encompassing the Edwards Plateau to the Balcones Escarpment, in the northern third of the county; the Tamaulipan, or South Texas Plains, beginning at the base of the Balcones Escarpment and extending south and west of San Antonio all the way to the coast; and the Texan, a mixture of prairie and forest, the southwestern edge of which forms the eastern part of Bexar County (Blair 1950). These different ecological zones mean a wide variety of food resources were easily available in a small area. This fact, and the abundant waters of the springs and creeks in the area, made what is now San Antonio a popular location throughout prehistory (Black 1985a:28).

The prehistoric period of south-central Texas began at least 11,000 years ago. During the entire period, until the European incursion, the Native Americans of south Texas were small nomadic bands of huntergatherers. Both archaeological and ethnohistoric sources indicate that people were highly mobile and ate a wide variety of plants and animals, moving from one area to another, exploiting the seasonal abundance of different resources (Black 1985b:12).

Agriculture was never practiced by the Native American groups in South Texas until the Spanish arrived. The adoption of a plain ceramic technology and a fairly abrupt change in projectile points and other tool types about A.D. 800 may indicate an adaptation to the presence of large numbers of bison which moved into the area at about that time (Black 1985a:32; Collins 1995; Huebner 1991).

It is important to realize that the Native Americans who lived in south Texas at the beginning of the eighteenth century were not the same cultures that had lived in the area for 11,000 years. Campbell and Campbell (1985) and John (1975) have pointed out that the effects of European invasions far to the west, southwest, and east had been spreading like ripples on a pond, disrupting the cultures around San Antonio for at least 150 years before the Spanish chose it as a mission site. As Campbell (1975:1) notes:

In the closing years of the 17th century the Indians of southern Texas already knew much about the Spaniards of northeastern Mexico, who had been established there for at least a full century. Many Indian groups of northeastern Mexico had been broken up by Europeanintroduced diseases and wars with colonizing Spaniards, and some of the remnants of such groups had moved across the Rio Grande into present-day Texas. Furthermore, the Spanish frontier of northeastern Mexico was not the only frontier that affected the Indians of southern Texas. There was also a southward- and southeastward-moving Athapaskan or Apache frontier.

Thus, by the time the Spanish began their colonization of the San Antonio River Valley, the local inhabitants of the region were the often fragmented remnants of cultures that had suffered the results of this disruption (Campbell and Campbell 1985:1). The largest group in the area was the Payaya, apparently a Coahuilatecan-speaking group, seen by the early Spanish visitors from the area near Austin all the way to the Rio Grande (Campbell 1975:4-10, 24). There were many other groups who eventually joined the first of San Antonio's missions. The mission records list at least one person from almost 40 different named groups. (Bolton 1970 [1915]:16). Many of these groups were represented by only one or two individuals in the records. Many of the groups for whom it is possible to identify their origin came from the Texas coast and northeastern Mexico (Campbell and Campbell 1985).

\section{Spanish Colonial Period (1718-1793)}

In 1718 Fray Antonio de San Buenaventura y Olivares finally achieved a decade-long dream: to move the rapidly failing Mission San Francisco Solano from its location on the Rio Grande to a site near San Pedro Springs which he had visited in 1709 
(de la Teja 1995:8; John 1975:206-207). Here, Olivares believed, the land could easily support a large mission. Governor Alarcón's motives in agreeing to the move had more to do with supporting the missions in East Texas and dealing with French encroachments into Spanish territory than in saving the souls of Native Americans (de la Teja 1995:7; John 1975:207). The location, at the border between what is now southwest Texas and northern Mexico, was highly strategic. A mission, presidio, and civilian community established at the head of the San Antonio River would provide a secure way-station between the Rio Grande and the East Texas missions (Habig 1968:38). Accordingly, with three other missionaries and a few mission Native Americans, Fray Olivares and Governor Alarcón established the Mission San Antonio de Valero on May 1, 1718. The mission was located on high ground west of San Pedro Creek, about a mile south of the springs (Habig 1968:38). Four days later, the Presidio San Antonio de Béxar and the civilian community of Villa San Fernando de Béxar were established, not far from the mission. Together these three communities formed the nucleus that would become San Antonio.

Sometime during 1719 , the mission site was moved to the east side of the San Antonio River, to what was seen as a better location (Habig 1968:42). This site was south of the present location, near where Commerce Street crosses the river today (Cox. 1994:1). With refugees from the East Texas missions to support the efforts of Fray Olivares, the mission was showing promise. By 1721, 240 Native Americans, mostly Payaya and Paymaya, were living at the mission (Habig 1968:40). However, in 1724 a hurricane devastated the mission compound, so it was moved to its present location (Habig 1968:44).

In 1727 Fray Paredes reported on the status of the mission to the College of Queretaro, the founding college of the mission. Although raids by Native American groups from the north-which became common at the mission and the nearby village until after the Civil War (de la Teja 1995:9-11; Jenkins 1973; John 1975:285)-were already a source of considerable inconvenience and danger, a small convento, a granary, and a temporary church had been built. Work on an acequia had continued, and material for a stone church had been collected, although they awaited the arrival of competent stone masons (Paredes 1727). By 1730 a small stone church, placed immediately south of the convento, had been constructed to serve as an interim chapel (Cox 1994:2).

The need for a master stone mason had become acute, if not desperate. Mission San José y San Miguel de Aguayo had been established five kilometers south of Valero in 1720 (Figure 4). In 1731 three East Texas missions were forced by French and Native American hostility to move to the valley of the San Antonio, becoming Nuestra Señora de la Purísima Concepción de Acuña, San Juan Capistrano, and San Francisco de la Espada. None of the five missions along the San Antonio River, however, had a permanent stone church.

In about 1738, master stone mason Antonio de Tello arrived. He was to design and begin building churches at all the missions except San Jose (Ivey et al. 1990:35). Tello began at Concepción, and when that church was well under way, started the new church at Valero. The cornerstone was laid on May 8,1744 . Work continued through the summer and by August the walls were apparently about half finished (Ivey et al. 1990:39). However, events in August 1744 conspired against the missionaries' plans for a completed church.

During the evening of August 21, 1744, a citizen of San Fernando named Matías Treviño was shot through the abdomen and died early the next morning ("Criminal Cause against Antonio de Tello" 1748, Bexar Archive Translations [BAT]. Reel 3, 15:71-102. Bexar County Courthouse, San Antonio, Texas). Treviño's dying declaration and further investigation made it clear that the assailant had been Antonio de Tello, the master mason, whose motive had apparently been to furnish the only kind of divorce possible to Treviño's wife, Rosa. Tello had taken refuge in the temporary stone church near the new one he was building at the Valero mission. 


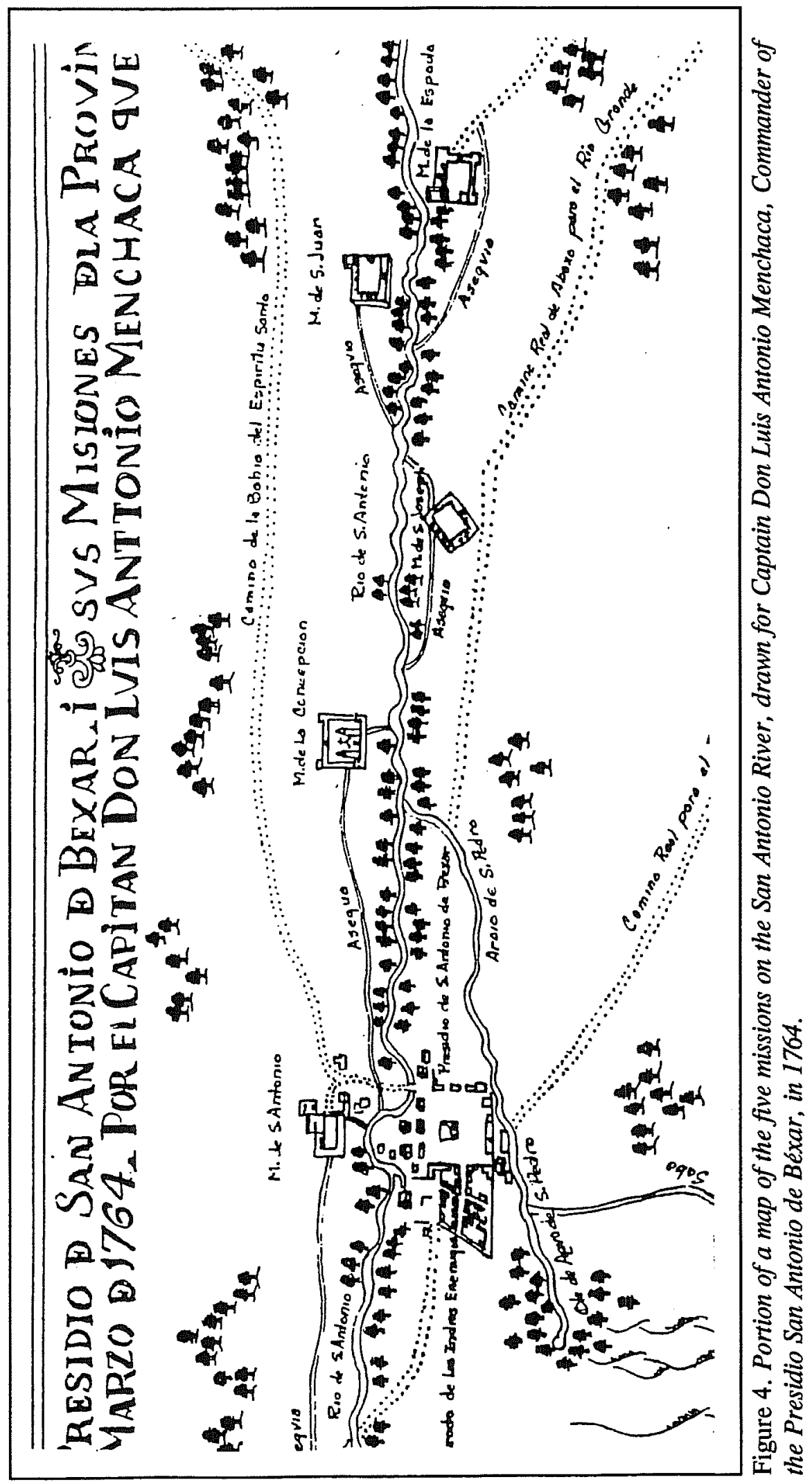


Questioned there, he claimed the incident was an accident. The alcalde (mayor) of San Fernando ordered guards to prevent Tello's escape from the church while he completed his investigation. On the morning of August 24, he ordered Tello arrested for murder, but soldiers sent to take him from the church found him gone (BAT, Reel 3 15:71-102). He was never seen or heard of again (Cox 1995).

Tello's departure left the missionaries in a quandary. They apparently decided that with the master's plans, and the experience gained by workmen at the nearly completed church at Concepcion, they could finish the church at Valero. They were mistaken. In his report 1762, Fray Mariano Francisco de Los Dolores y Biana, stated that "the church of this mission, although finished perfectly with its tower and sacristy, tumbled to the ground because of the bad intelligence of the maker" (Schuetz 1966:21). The collapse probably happened sometime during 1750 , because burial records of November 16 and November 26,1749 , record the only three burials which explicitly state the location of the graves: inside the new (and presumably finished) church (Leal 1978).

The disastrous collapse appears to have prompted the arrival of Hieronymo Ybarra, another master mason, in 1751 (Ivey et al. 1990:41). Ybarra cleared the rubble of the fallen roof, took the walls down to where Tello had stopped work (Ivey et al. 1990:41), and began to rebuild. Progress was slow, probably due to lack of manpower, because it was not until 1758 that the keystone of the arch over the front entrance was laid (Ivey et al. 1990:41). In 1762 Dolores reported that the church "is being built again of harmonious architecture with hewn stone, half finished with the solidity and perfection that is required for its beauty and to sustain the vaults" (Schuetz 1966:21). The sacristy did receive a roof, and after about 1760 , when the old temporary stone church was demolished, mass was held in this room (Schuetz 1966:30). Ybarra seems to have had at least one apprentice, because the record of the burial of Estevan Losoya, a Native American, in 1767, declared that he was a maestro de alvanil, a master stone mason (Leal 1978). But problems continued to plague the construction and the church was never finished.

In 1789 Fray Jose López reported that only 52 Native Americans lived at the mission (Habig 1968:65), hardly enough to work the fields, much less to continue work on the church. He described the church as having

a very large nave and a transept; the walls of the nave are built as high as the cornices, but the latter have been built only in the dome of the sanctuary. In front, its beautiful facade of sculptured stone has been completed to the same height as the walls. At this point the construction stopped many years ago for lack of qualified workmen. For this and other reasons . . . it cannot now be carried to completion [Habig 1968:64-65].

Fray López also noted that, although the mission was now some 70 years old, the majority of the Native Americans in residence there had converted as adults (Habig 1968:65). The mission did not yet have a stable, established community with converted Native Americans living out their lives and baptizing their children, but was still relying heavily on new converts. Most of the Native Americans who came to the missions (or were born there) either left again or died very young. Hinojosa (1991:75) has pointed out that over two-thirds of the 319 Native Americans who were found in both baptism and death records from Valero died before the age of three. Only eight from this group lived to the age of 30 .

Between 1727 and 1762, the Native American population of the mission, averaging a little more than 270 (Figure 5), had remained more or less stable except for the year 1739 when a plague of small pox and measles devastated all the missions (Casteñeda 1938:71). But after 1762, the population was much lower than in previous years, averaging only about 80 , and fluctuating wildly. 


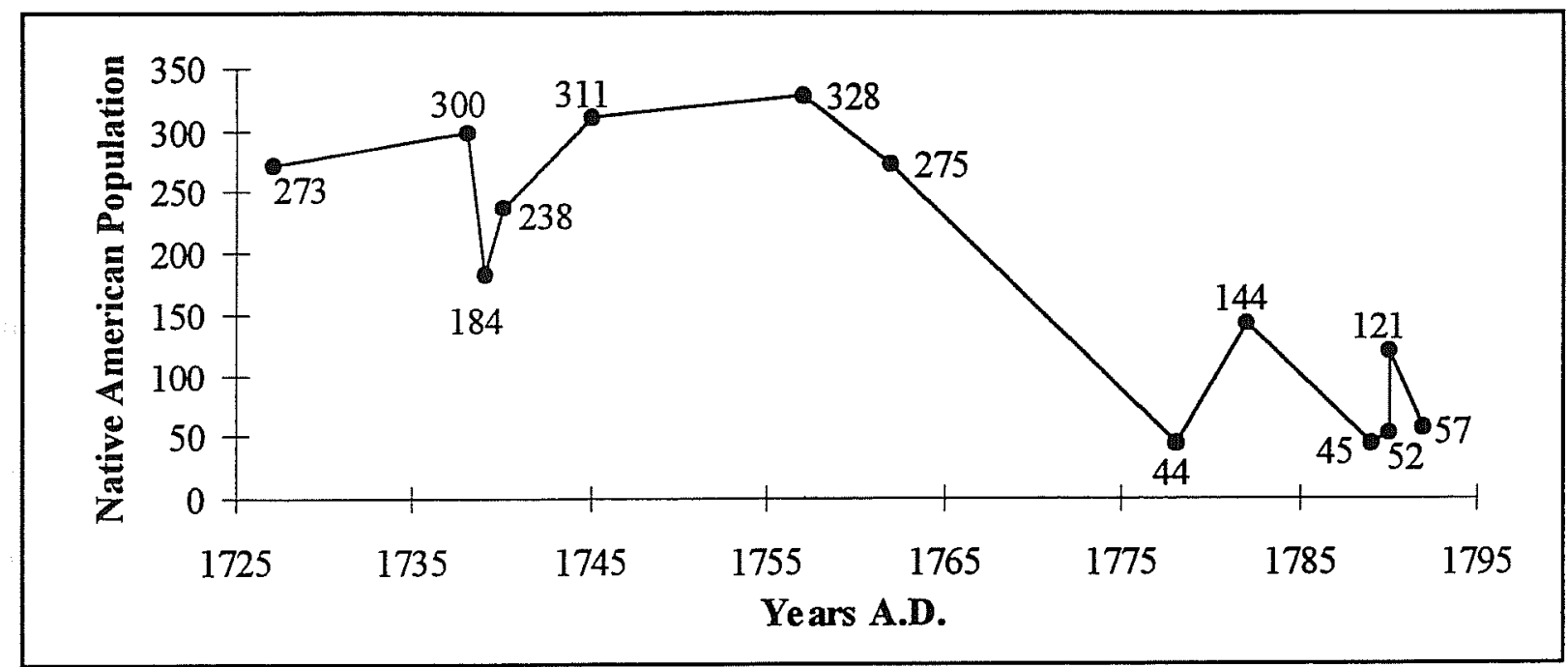

Figure 5. Native American population changes at Valero. Data are from Habig 1968 and Schuetz 1966.

However successful the mission effort had been at the beginning (Casteñeda 1938), it was clearly in decline by the late-eighteenth century. In 1793, a royal decree secularized Mission San Antonio de Valero, and the mission lands were divided among the 15 remaining mission Native Americans and 54 local Spanish citizens (de la Teja 1995:86). The mission records were turned over to the San Fernando parish (Habig 1968:70).

\section{Spanish Army Period (1801-1810)}

The unfinished church lay deserted for only a few years. Spain was concerned by the upcoming sale of the Louisiana Territory to the United States, and wanted to strengthen the province of Texas. In 1801 the Segunda Companta Volante de San Carlos de Parras del Alamo (the Second Flying Company of San Carlos of Parras of the Alamo) was assigned to enhance the Presidio de Bexar. They established themselves in the old mission buildings at San Antonio de Valero and erected barracks, some inside old buildings (Fox et al. 1976:6-7). It was the name "del Alamo," celebrating the little town near Parras, Mexico, where the company had been recruited, that became the name of the garrison and the little pueblo in and around the old mission compound (Habig 1968:71). A small parish, San José y Santiago del Alamo, was established for the soldiers and other residents in the immediate area. The parish met in the sacristy of the uncompleted mission church, the only part of the building with a roof (Habig 1968:70).

In 1806 the Spanish army established a hospital, the first in what is now San Antonio, in the old convento building, and eventually a doctor and a dentist were available (Schuetz 1966:34-35). In 1808 a two-room pharmacy was built inside the unfinished church (Almaráz 1971:85). These medical facilities were later opened to the civilian population.

Spain's fears concerning the aggressiveness of New Spain's young neighbor to the northeast were being justified, almost daily. The United States ambassador in Madrid insisted that the Louisiana Purchase included all lands north and east of the Rio Grande (this being the original claim of France which it had never been able to enforce). Also the United States assembled its armed forces in Louisiana (Garrett 1968[1939]:12), taking full advantage of the chaos in Spain caused by the claim of Napoleon to the Spanish throne. French agents encouraged rebellion against the viceroy, who was loyal to King Ferdinan VII (Garrett 1968[1939]:15). The combined threat to Spanish sovereignty in the New World made the security of Texas vital, but the officials in Mexico City had other, more local and, in their minds, more pressing problems. Rising Mexican nationalism threatened royal control. Neither money nor troops 
were available for the frontier outposts, however threatened. Manuel Salcedo, the nephew of the viceroy and governor of Texas, insisted that Texas deserved the full attention of the government, but as of 1810, little had been done (Garrett 1968[1939]:27).

\section{The Revolutionary Period (1810-1836)}

On September 16, 1810, Father Hidalgo, claiming the Spanish government was about to turn Mexico over to the French, declared revolution. During the next months, rebellion was fomented all over the northern part of Mexico. Governor Salcedo arrested agents in Villa San Fernando (San Antonio), his own capital, who were delivering propaganda (Garrett 1968[1939]:35). While trying to fight the emerging revolution in Texas, Salcedo was ordered by the viceroy to send troops to the Rio Grande. For the soldiers, this meant that the relative comforts of the Alamo and nearby San Fernando, where they had been stationed for nine years, were to be abandoned and they were to fight fellow Mexicans instead of the Nortenos (literally "northerners," i.e. Apaches, Comanches, and other Native American groups from north of the settlement) who had been their foes. The displeasure of the troops was encouraged by rebel agents (Garrett 1968[1939]:40). On the evening of January 21,1811 , in the barracks along the south wall of the former Mission San Antonio de Valero, final plans for a mutiny were completed (Garrett 1968[1939]:44). The next morning, rebels captured Salcedo and several other officials and loyal officers. They were later sent to be imprisoned by fellow rebels holding the Presidio San Fernando on the other side of the Rio Grande (Almaráz 1971:119).

The town was retaken by men at least nominally loyal to the Spanish government on March 2, 1811 (Almaráz 1971:121). Meanwhile, at Presidio San Fernando, Salcedo had talked his jailer, Ignacio Elizondo, into returning to the loyalist fold. The news from Bexar encouraged them. In the midst of all the chaos, on March 11, 1811, the viceroy ordered that the two pueblos of San Fernando de Béxar and San
Antonio de Valero be incorporated under the name San Antonio de Béxar (the original name of the presidio established there in 1718), apparently in a move to encourage the loyalists there (Menchaca 1937:14).

Salcedo and Elizondo set out to destroy the rebellion. Making use of Elizondo's change in loyalties, they succeeded in capturing and executing Father Hidalgo and virtually all the major leaders of the rebellion (Garrett 1968[1939]:72). The immediate danger from the rebellion in Texas was over, but Salcedo insisted that trouble was still brewing. He did not want to return as governor unless he was promised more support from the viceroy, including a public exoneration from the events of January (Almaráz 1971:127).

Salcedo was correct: the revolution, although seriously hindered, was not quelled. José Bernardo Gutiérrez de Lara became its next great leader (Garrett 1968[1939]:83). In August 1812, with American adventurer Augustus Magee, Gutiêrrez invaded Texas with the self-styled Republican Army of the North, composed largely of American volunteers (Garrett 1968[1939]:151). Desperate, Salcedo begged for help from the viceroy, but received little (Almaráz 1971:160-161). Instead, he attempted to defend Texas with the troops he had. In March 1813, after losing a battle to the invading army not far from San Antonio, Salcedo surrendered the city. Gutierrez spent the night at the Alamo garrison before following his vanguard into the city (Menchaca 1937:14). Salcedo and about 13 other officers were imprisoned at the Alamo (Filisola 1985 [1848]:20). Later they were taken out of San Antonio, under pretext of sending them to Matamoros, and murdered (Almaráz 1971:171). This action disgusted many of the Anglos and some 100, including one of their most important leaders, Samuel Kemper, returned immediately to the United States (Filisola 1985[1848]:21). On April 6, 1813, a declaration of independence from Spain was signed. Texas was the first state of the future Republic of Mexico to be free (Garrett 1968[1939]:182). 
The "freedom" of Texas did not last long. In August 1813, José Joaquin Arredondo, sent to end the rebellion, destroyed the republican army outside San Antonio. During the next few weeks some 375 people-the remains of the rebel army and numerous citizens of San Antonio-were executed. Some of the bodies were left in the plazas until March of the next year, when the parish priest at San Fernando church requested permission to bury them (Cox 1990:9). The wives and older daughters of these men were rounded up, imprisoned, and put to hard labor (Fehrenbach 1968:126; Filisola 1985[1848]:32).

Arredondo's zeal to punish the rebellious province resulted in serious depopulation of San Antonio and the surrounding areas, partially due to the large numbers of refugees who fled the Spanish wrath (Garrett 1968[1939]:228). In his old age, Antonio Menchaca, who was 14 years old in 1813, had bitter memories of the months after the destruction of the rebellion. Describing one regiment, he wrote "they did not seem to be other than devils" (Menchaca 1937:19). The inhabitants of the city were brutally treated by Spanish soldiers, surrounded by hostile Native Americans, and nearly starved during the winter of 1814 (Menchaca 1937:19).

The desire for autonomy from Spain could not be destroyed. Another revolution, in which Texas was only peripherally involved, finally ended Spanish sovereignty in Mexico in 1821. Within a few years, conditions in San Antonio improved considerably (Menchaca 1937:20). The improvements did not, however, end all rebellious plots. Despite attempts by the Mexican government to control it, the influx of Anglo-Americans into Texas increased dramatically in the years after 1820. The Anglo-Americans came to Texas in hope of a better life, and for the most part, found it. However, they were accustomed to the relative freedom of the United States and found the strictures of Mexican citizenship onerous (Fehrenbach 1968:167). Mexico lacked trial by jury, freedom of the press, and freedom of assembly; yet, ironically, it was the slavery issue that caused the most trouble. The newcomers wanted to continue the practice of slavery in Texas, even though it had been illegal in Mexico since 1824 (Tijerina 1994:110). The Mexican government wanted to enforce the antislavery laws as part of the overall effort to remind Anglo colonists that Texas was a part of Mexico and subject to Mexican law (Filisola 1985 [1848]):62).

The Tejanos, Hispanic Texans, were not happy with the central government either, although for somewhat different reasons. The long fight for freedom from Spain had been fought by the citizens of Texas at enormous cost. The survivors and their sons welcomed the Republic of Mexico. But conflict between federalists, who wanted relative freedom for each region, and centralists, who wanted the same kind of strong, centralized government which had always ruled Mexico, had its counterpart in Texas. The Tejanos, perhaps because of closer contact with the Anglo-Americans notions of states' rights, were much more federalist than the average Mexican citizen. The final betrayal, in 1835 , by supposed federalist Antonio Lopéz de Santa Anna and destruction of the Constitution of 1824 infuriated them. After each of a series of small, unsuccessful rebellions against Santa Anna the Tejano ranks were swelled by federalist refugees (Fehrenbach 1968:185). But the haughty treatment of Tejanos by many Anglo Texans guaranteed that most would remain loyal to the Mexican government, no matter how despicable its current leadership. Otherwise they feared they would become second class citizens in either a United States possession or a new country dominated by Anglo-Americans. There were exceptions-some famous, such as Lorenzo de Zavala, Juan Seguín, Juan Antonio Navarro, and Placido Benavides-who openly joined the Texas rebellion (Fehrenbach 1968:200).

The incidents leading to the battle which is the most famous event at the Alamo are well known, although some details are still somewhat controversial. A detailed discussion of these events is not included in this report. Instead, a very brief outline of the separation of Texas from Mexico is presented. The reader is referred to Barr (1990), de la Peña (1975), Fehrenbach (1968), and Lord (1961) for a more complete examination of the Texan Revolution. 
In 1835 General Martín Perfecto de Cós, Santa Anna's brother-in-law, had just put down a rebellion in Coahuila and was ordered to regain complete control of Texas as well. He first sent troops to collect a six-pound cannon from Gonzales, where it had been used in the defense of the town against Native Americans. Open revolt against Mexico began in Gonzales on October 2, 1835, when local Texans refused to turn over the cannon, and fired shots at the Mexican troops sent to retrieve it (Fehrenbach 1968:192-193).
At the same time, General Cós was busy fortifying the old garrison at the Alamo (Figure 6). He knocked down the arches of the unfinished church ceiling and used them as part of the fill needed to build a ramp sloping from the front door to the top of the back wall (Letter from S. A. Maverick to S. M. Howe, July 3, 1847, in Young 1991:32). At the back wall, scaffolding was built to hold cannon and men behind the relative safety of the stone walls (Cox 1994:6). The walls of the old mission compound, now largely in ruin, were rebuilt to the extent possible, and a

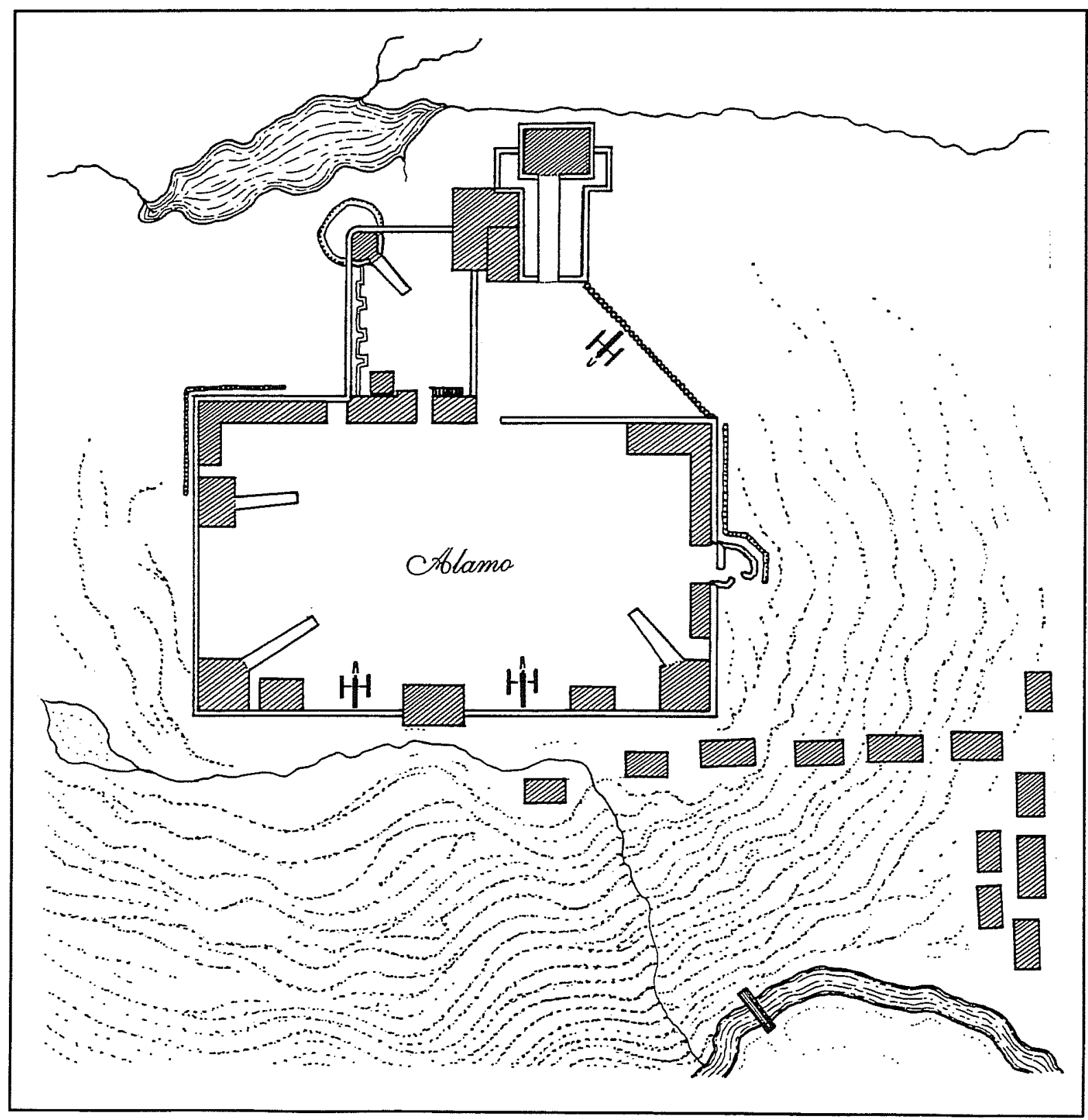

Figure 6. The Alamo in 1836. Redrawn from the map made for Santa Anna by Colonel Ygnacio de Labastida, commander of engineers. 
wooden palisade and ditch were built from remaining buildings on the south wall to the southwest corner of the church, completing the enclosure (Cox 1994:6).

After their success at Gonzales, the Texans decided their next step was to take San Antonio. As the "Army of the People" approached, Cos pulled his troops into town and the Alamo, and resolved to wait them out. After a month of waiting, with only small skirmishes to break the monotony, the Texans were losing enthusiasm rapidly. They were packing to return to Gonzales when a Mexican deserter from San Antonio told them that the Mexican army was in even worse shape than they. They hesitated, and might have continued their retreat if Colonel Ben Milam, who we now know was seriously crippled with arthritis (Tennis 1995), demanded "who will follow Old Ben Milam into San Antonio?" (Fehrenbach 1968:197). This highly dramatic scene restored the Texans' enthusiasm, and some 300 men followed Milam into the town early on the morning of December 5. After a three-day, house-to-house battle, the Texans captured the town. Ben Milam was killed on the third day by a bullet through the head (Fehrenbach 1968:197-198; Tennis 1995). On December 10, Cós surrendered his garrison at the Alamo and, after signing a parole promising never again to fight against the colonists or to defy the Constitution of 1824 , was allowed to leave with his troops.

By January 1836, the political chaos in Texas had reached an untenable level, with two governors, four supreme commanders of the Texas army, and the nearest thing to a governing body, the "Permanent Council" unable to raise a quorum (Fehrenbach 1968:202-203). In the midst of all of this, J. C. Neill, James Bowie, William Travis, and, somewhat later, David Crockett, managed to keep their attention on the fundamental problem that Texas faced: Santa Anna would be coming, and he would come first to San Antonio. The Alamo was the obvious place to form a defense, but the Texans needed many more men than were available. The engineer, G. B. Jameson, had grandiose but, given the situation, impossible plans for rebuilding the fortress along more defensible lines (Jenkins 1973:352). Sam Houston later claimed that he sent Jim Bowie there with explicit orders to blow up and abandon the Alamo (Hardin 1994:110). If so, then Bowie either disobeyed him or interpreted his order as a suggestion-which he did not take. Bowie insisted that they could not afford to let the Mexican army have San Antonio, as it was the last stronghold between Santa Anna and the Sabine River (Fehrenbach 1968:205).

When the decision to hold the Alamo was made, no one had any idea how quickly Santa Anna was coming. The humiliation of Cós, his brother-in-law, seems to have motivated Santa Anna into moving much faster than the Texans anticipated (Cox 1994:7). On February 10, 1836, during a ball attended by military and city leaders, a courier arrived with a letter stating that Santa Anna had left the Rio Grande with a huge force of men and cannon (Menchaca 1937:22). Apparently many Texans refused to believe the report, not trusting the "Mexican" source (Williams 1933:287), but on February 23, the Mexican army arrived. Thirteen days later, on the morning of March 6, 1836, the Alamo fell and all defenders were killed. Some reports claim the Texans died fighting, while others state that some surrendered and were later shot (Kilgore 1978). Santa Ana's brutal methods, which seemed so inhumane to Anglo-Americans, had a long tradition in Mexico, and were infamous in San Antonio. Santa Anna had learned to subject rebels to immediate execution while he was one of Arredondo's lieutenants during the royalist occupation of the city some 23 years before.

In the past, destruction of the rebel forces in San Antonio rapidly led to an ending of open rebellion in Texas, and Santa Anna probably thought the same would happen again, especially after the capture and subsequent execution of Fannin's men at Goliad. He failed to realize that the center of this rebellion was not in San Antonio, and that the men he fought were not the peasants he was accustomed to fighting. Instead he faced men with a tradition of successfully fighting for freedom and with expectations of help 
from the United States. Houston's strategy of falling away before the Mexican army must have convinced Santa Anna that he was succeeding in sweeping the foreigners out of Texas.

Actually, Sam Houston, now the undisputed commander of the Texan army, was attempting something else entirely. He understood that a "Texas" independent of Mexico existed only so long as his army existed. He followed a course much like George Washington's plan, to "avoid a general Action or put anything to the Risque" (quoted in Weigley 1986:412). This was very much against the prevailing military theory of the time which held that wars are won by aggressively seeking and winning battles (Weigley 1986:416). Although most of his men believed that the Anglo-Americans could outmatch the much larger and better-trained Mexican army, Houston refused to face Santa Anna in formal battle. He was vying for time, waiting for more volunteers and supplies from the United States, training his army, and looking for an opportunity (Fehrenbach 1968:229).

The opportunity came the third week in April, at San Jacinto. Houston recognized that he had no more time, and allowed himself to be "caught." Then, inexplicably, Santa Anna, apparently confident that he could destroy the smaller army before him and chase the remaining Anglos out of Texas, was caught completely by surprise by the Texan army. The battle on April 21 was short and bloody. Still angry about the Mexican army's treatment of prisoners at the Alamo and Goliad, the Texans captured Santa Anna and slaughtered large numbers of Mexican soldiers as they tried to surrender. To earn his release, Santa Anna signed a treaty agreeing to pull all Mexican soldiers south of the Rio Grande, and never again to fight against Texas (Fehrenbach 1968:241). Although Mexico repudiated the treaty immediately upon Santa Anna's release and border skirmishes continued for a decade, Texas was now an independent nation (Fehrenbach 1968:246).

When Santa Anna left San Antonio, Colonel José Andrade and about 1,000 Mexican soldiers were left behind to control the city. After the battle at San Jacinto, Andrade was ordered to depart, after rendering the Alamo useless as a fortress. Andrade spiked cannon he could not take with him, tore down single walls, including the palisade wall, and set fire to the scaffolding inside the church (Cox 1994:7). When he and his soldiers marched out of San Antonio, the Alamo was in ruins (Figure 7).

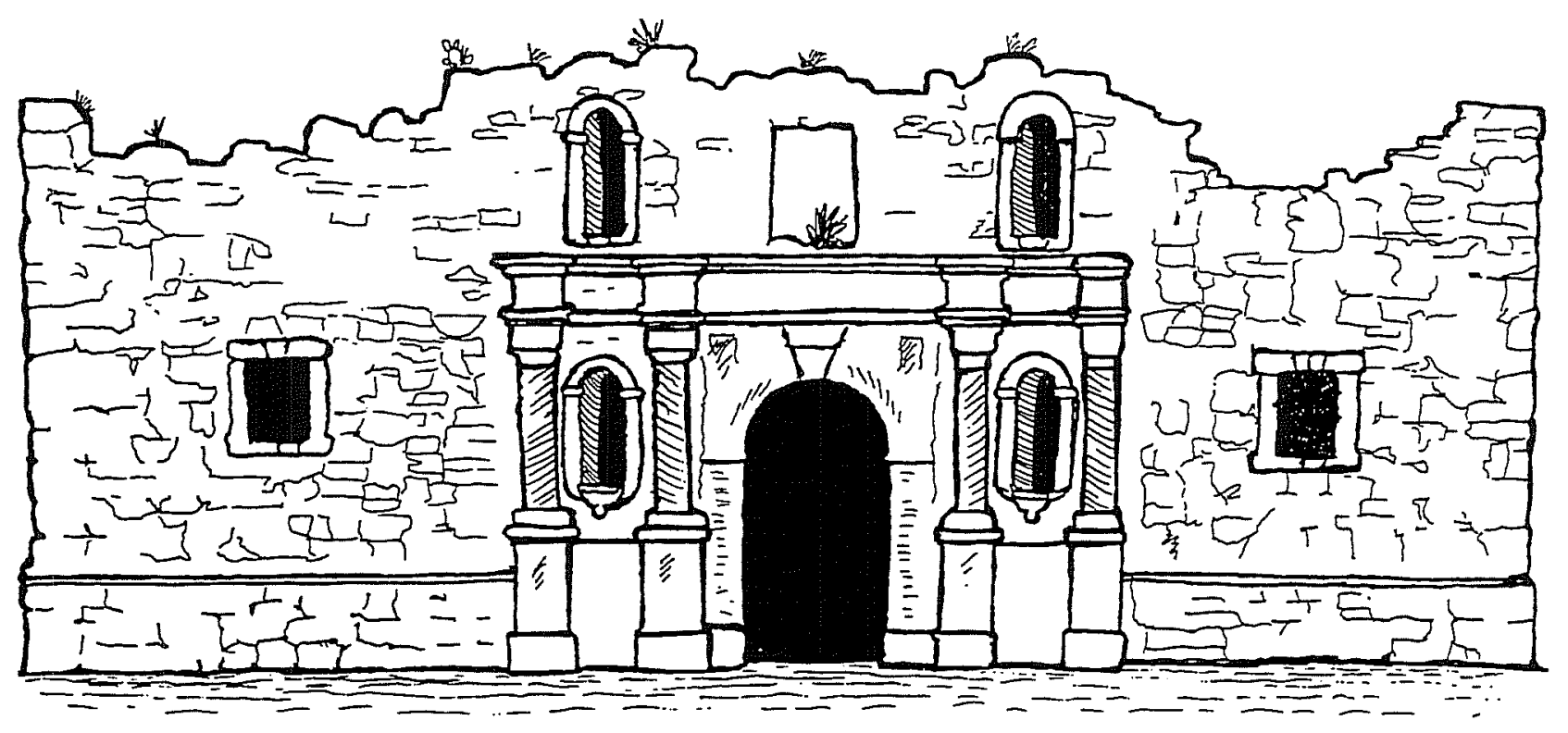

Figure 7. The ruins of the Alamo. Drawing based on engraving made in 1848 (adapted from Schoelwer 1985:46). 


\section{The Republic of Texas Period (1836-1845)}

The people of San Antonio had endured 25 years of rebellion and retaliation. Three times the town and its garrison at the old mission had been taken and punished by rebels, and three times it had been retaken and punished by government soldiers. Having survived this turmoil, the citizens of San Antonio now found themselves citizens of the Republic of Texas. Between 1836 and 1845, Texas was an independent nation. For San Antonio, these were not quiet years. The Native American groups living nearby had become even more aggressive than before (Jenkins 1973:56-94), and Mexico, after a few years of ignoring Texas, began to regularly raid across the Rio Grande. In the spring of 1842, San Antonio was briefly captured and sacked by the Mexican Army (Jenkins 1973:95), and a number of Anglo Texans were captured and taken back to Mexico (Paulus 1939:62). Later the same year another Mexican force attempted to take San Antonio, but was repulsed in a bloody battle (Jenkins 1973:95-96). In October 1845, the U.S. Army set up camp in San Antonio, responding to President Polk's order to secure the Texas border until the annexation question could be settled (Cox 1994:12).

\section{U.S. Army Period I (1845-1861)}

The intention of many, if not most, Anglo Texans had always been to join the United States, and after nine years this became a reality. Mexico was furious with the United States for ignoring their continuing claim to Texas (Faulk and Stout 1973:2), and on April 23, 1846, Mexico declared war on the United States. The next day Mexican troops crossed the Rio Grande with the intention of eventually retaking all of Texas (Faulk and Stout 1973:1). During the two years of war which followed, San Antonio served as the staging area for all U.S. Army operations in Mexico and the Southwest (Cox 1994:12).

Although the Catholic church had been granted ownership of the Alamo church and convento by the Texas legislature in 1841 (Schuetz 1966:38), the church did not use the old mission during this period. Instead the grounds of the Alamo garrison were primarily used as a playground. In 1905 one man described his activities as a child in 1845: "we boys could run up the embankment [the remains of the ramp inside the old church] to the outer wall and onto the roof of the convent building-it was a famous playground" (Everett 1975:18). He also mentioned that the old building was inhabited by a large colony of bats and "in the twilight the bats would pour forth in myriads" (Everett 1975:18).

Other visitors to the town noted the depressing neglect of the famous battle site. One newcomer to San Antonio wrote, "the historic square lay muddy, covered with weeds, unkempt and neglected, its shrine standing gaunt and desolate" (Barber 1973:27). Another observer wrote that the old church was "choked with debris of stones, mortar and dirt, causing an embankment from the base to the top" (Chabot 1935:41) (Figure 8).

By the end of the war with Mexico, the need for a permanent military presence in San Antonio had become clear. In 1848 the U.S. Army, after considerable argument concerning the ownership (Young 1991), leased the Alamo church and convento from the Catholic church, and began restoring some of the buildings for use as a Quartermaster's Corps depot (Cox 1994:12, Figure 8). Some questioned whether the old church should be torn down or repaired; the latter course was taken, not out of respect for its antecedents but as an economic measure (Young 1991:5). By 1850 the army had repaired the old convento building, built a number of small outbuildings in the convento patio, and put a roof on the church, its first after more than 100 years of existence. To accomplish this, the army cleaned out the interior, removing the remains of General Cós's ramp; raised the walls to a level; built a wooden roof; and put a cap over the original facade of the building. It is this cap which forms the most famous architectural outline in Texas (compare Figures 7 and 9). The windows in the south transept and other parts of the building were probably also installed at this time. In January 1850, the city 


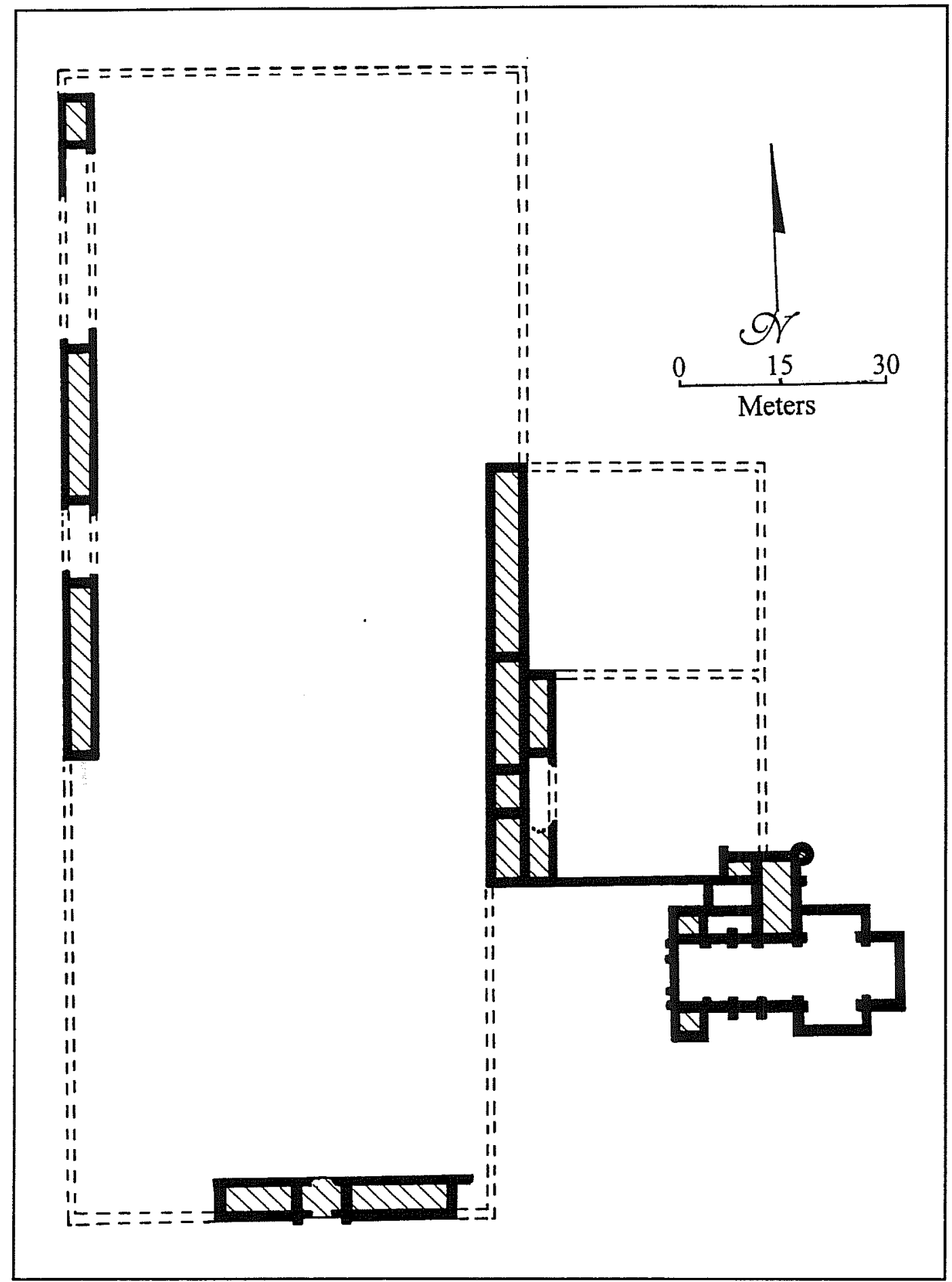

Figure 8. The remains of Mission San Antonio de Valero, from a plan drawn in 1846 by Edward Everett.

council of San Antonio decided the city was the legal owner of the buildings, sued the Catholic church to gain title, and demanded that "all rents and dues for the use of said building and property will be required to be paid by the acting Quartermaster into the treasury of the city" (City Council Minutes [CCM], Office of the City Clerk, City Hall, San Antonio, Texas, Book B, p. 71). The issue went all the way to the Supreme Court of Texas, which ruled in favor of the church in 1853 (Story 1938:39). 


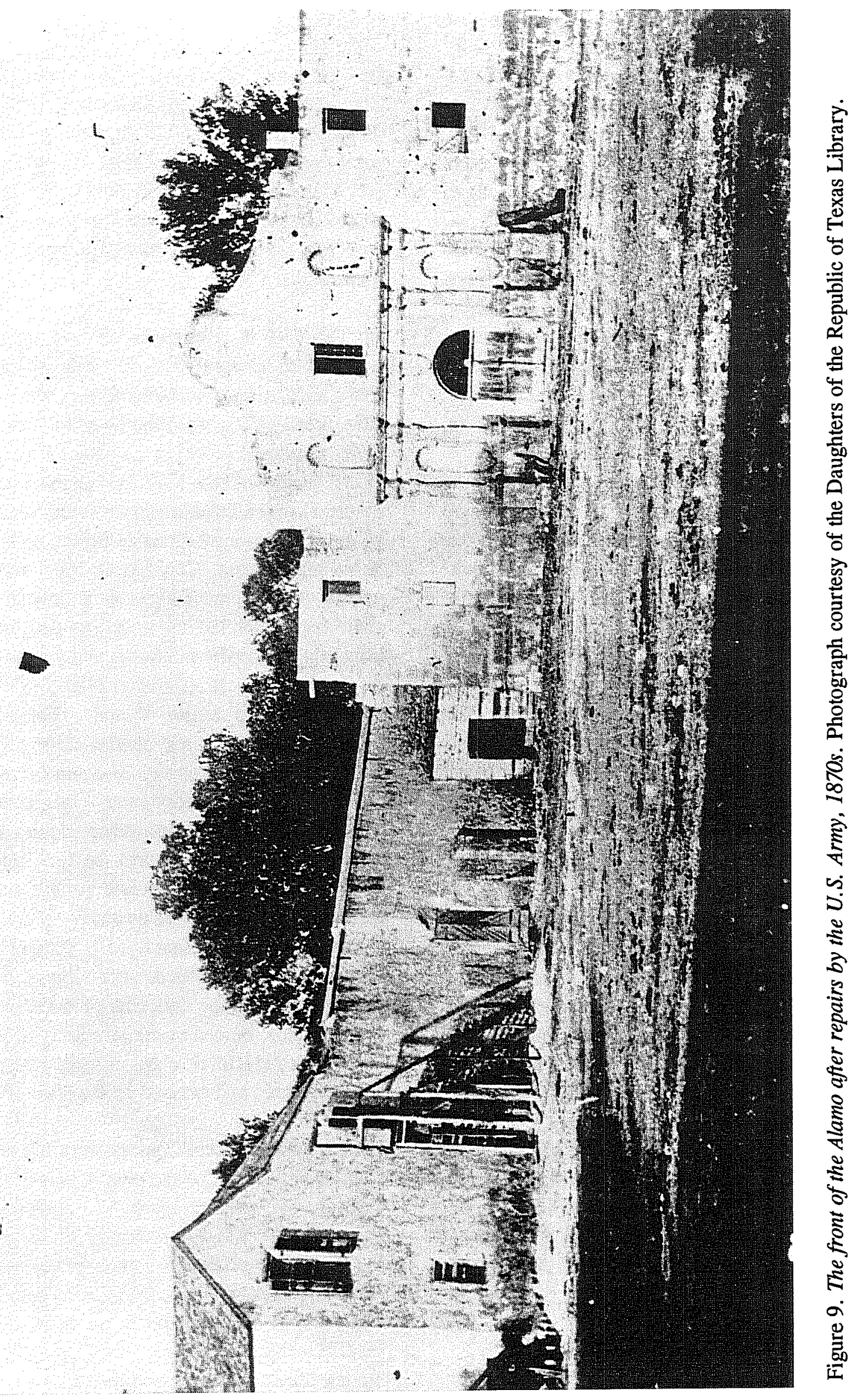


The matter of ownership having been settled, the Quartermaster's Corps finished construction of the depot. During his inspection of the premises in 1854, Lt. Colonel W. G. Freeman approved the establishment, noting that most of the grounds were leased from the Catholic church, the rest from Samuel Maverick (Cox 1994:14). The presence of the army depot increased traffic around Alamo Plaza enormously. A hundred wagons a day brought supplies from the port at Indianola or took them to various frontier forts (Cox 1994:14). The increased activity attracted other businesses. The Menger Hotel, just south of the Alamo, was completed in 1859 and several saloons opened nearby.

Samuel Maverick, who had purchased most of Alamo Plaza in 1841, and John Giddings, who bought the lands behind the church, had subdivided their properties and began selling the lots (Cox 1994:14). A brewery, meat market, and the bustling activity around the Quartermaster's depot made Alamo Plaza one of the centers of commerce in San Antonio (Cox 1994:16). However, the relative peace of San Antonio after 1846 was about to be shattered again. Tension between the North and South had become intolerable. The news of Lincoln's election late in 1860 was, for the South, a signal for rebellion.

\section{Confederate Army Period (1861-1865)}

In late January 1861, an election was held in San Antonio for delegates to a state convention which would consider secession from the United States (Darrow 1884-1887:33). Although the large German and French populations of San Antonio, as well as most of the military men stationed there, were loyal to the Union, the secessionists won the election by a slight majority. Caroline Darrow, whose husband was a confidential clerk to Major Vinton at the Quartermaster's depot and who was not neutral on the subject, claimed that this victory was the result of "superior political diplomacy," by which she meant tricking illiterates, bribing itinerant teamsters, and outright ballot fraud (Darrow 1884-1887:34).
On February 1, 1861, the Texas Secession Convention passed an Ordinance of Secession (Fehrenbach 1968:344). Though the ordinance was not supposed to be official until March 2, and then only if a popular vote confirmed it, the convention turned immediately to the question of federal property, particularly military property, in Texas (Fehrenbach 1968:346).

On February 4, a commission was appointed "to confer with General Twiggs, with regard to the public arms, stores, munitions of war, etc., under his control and belonging to the United States, with the power to demand [them] in the name of the people of Texas" (Darrow 1884-1887:34). General Twiggs, in command of the Department of Texas, was believed by many to have questionable loyalty to the United States government. Caroline Darrow overheard a remark by General Twiggs to a lady at a social gathering, which led her to believe that the general intended to surrender his forces and federal property to the state forces (Darrow 1884-1887:34). She reported this to Major Vinton. Though he was reluctant to believe his commanding officer was disloyal, later information-again from Mrs. Darrow-made him uneasy enough that he decided to remove all papers in his possession which could be of use to the state forces against the U.S. military. In the middle of the night, these papers and all the government moneys in his possession were removed from the Alamo, and sent to Mrs. Darrow, who hid them in and around her home (Darrow 1884-1887:34). The concerns of the Darrows and Major Vinton seemed even more justified when Ben McCullock and a force of ardent secessionists arrived in San Antonio and camped on the edge of town.

Concerns about General Twiggs were felt elsewhere. Colonel Carlos A. Waite was assigned to replace Twiggs, but did not reach San Antonio in time (Bowden 1986:58). On February 15, news reached San Antonio that Twiggs was to be replaced (Story 1938:43). That night, according to a Captain Potter, Twiggs told him, "there is no need of sending [McCullock] to coerce me. If an old woman with a broomstick should come with full authority from the 
State of Texas to demand the public property, I would give it up to her" (quoted by editors in footnote, Darrow 1884-1887:38). At about 4:00 A.M. the next morning, McCullock and a force of about 1,000 men infiltrated the town (Bowden 1986:51; Darrow 1884-1887:34) and took possession of the arsenal which was temporarily housed in a building about a mile and a half from the Alamo (Fox 1986:4). They also marched to the Alamo and demanded that the army surrender and deliver all federal property to them.

Twiggs briefly refused, but by noon of that day he had formally surrendered the entire U.S. Army Department of Texas-then some 15 percent of the United States land forces-to the secessionists, without a shot being fired (Bowden 1986:2-3). Two days later, Twiggs issued General Order Number 5 , which delivered all federal military property in Texas to the state. Federal troops in Texas were permitted to leave by way of the coast, carrying small arms and enough equipment and stores to get out of the Confederacy (Bowden 1986:57).

It is not known today if Twiggs was actually in conspiracy with McCullock and the other secessionists-as many believed at the time (Darrow 1884-1887:34)-or was simply sympathetic. The timing of the assault by McCullock and the subsequent surrender is suggestive, since the secession of Texas would not be official until two weeks later (assuming, as everyone did, that the popular vote concurred). The news received the day before the assault that Colonel Waite, a known Unionist, was being sent to replace Twiggs, may have forced their hand. In any case, Governor Sam Houston had no doubts. The day he was replaced by Edward Clark for refusing to take his oath of office under the Confederacy, he stated, "it is the first time in the annals of our country that a General of the United States Army has conspired with a revolutionary committee to overthrow and supplant Executive authority, which was his duty to sustain and defend" (quoted in Bowden 1986:56-57). Within a few weeks of the surrender, Twiggs had reached New Orleans, accepted a commission as major general in the Confederate Army, and been given command of the district of Louisiana (Bowden 1986:61).

During the war, San Antonio, the only town of any size between Austin and the Rio Grande, became the central clearing house for cargo going to and from Mexico. Goods from Mexico came to San Antonio and were dispersed across the South (Kerby 1972:182). In return, cotton was shipped through San Antonio to Mexico in huge quantities (Kerby 1972:180). The traffic in San Antonio was so heavy that the city had to levy a tax on incoming cargo to pay for street and bridge repairs and the disposal of dead draft animals. The large, unruly crowd of drivers in town made "murder and riot an almost nightly occurrence" (Kerby 1972:179). This traffic, however, did not prevent shortfall of supplies to the citizens. In 1863 Samuel Maverick's wife complained of having to stand for hours, waiting for a chance to buy shoes, a bolt of cloth, and a little coffee (Kerby 1972:185). In 1864, a letter to the government from several women of San Antonio complained that "we have [spinning] wheels and cards and they are dull for the want of cotton" (quoted by Kerby 1972:203).

In the midst of the bustle the Alamo suffered a serious mishap. In 1861 two young boys smoking inside the old church started a fire that gutted the building (Cox 1994:18). The second floor and the wooden roof were destroyed, and part of the front wall fell. The Confederate Army rebuilt the building (Fox et al. 1976:21).

More than a month after the surrender of Lee at Appomattox, the last pitched battle of the Civil War took place near Brownsville (Fehrenbach 1968: 389-391). There was never a formal surrender in Texas, but the Confederacy-both military and civilian-simply faded away. The bitterness over the defeat was at first aimed at the politicians of the Confederacy. There are many cases of ex-soldiers seizing state property, including military stores in San Antonio, and distributing it to indigent military families (Fehrenbach 1968:394). 


\section{U.S. Army Period II (1865-1876)}

The Reconstruction period in Texas was particularly difficult, but San Antonio fared somewhat better than much of the state for three main reasons (Cox 1994:18-19). Having done reasonably well economically during the war, the city now suffered as trade with Mexico diminished. However, the problem was partially mitigated by the return of the U.S. Army, even though the relationship between the town and the military had changed. Before the war, the military and the civilian population had considerable social as well as economic contact, but afterward "the Southerners looked askance at the army folks and would not meet or mingle with them" (Florida Tunstall Sharp, quoted by Paulus 1939:59). While no longer welcome at social functions, the army was at least a source of cash income (Cox 1994:19). San Antonio's second advantage was that cattle from South Texas, needed to satisfy the enormous demand for beef in the North, came through the city (Cox 1994:19). Finally, San Antonio had a political advantage over much of the state. The city had been home to many Unionists and, unlike most of Texas, military authorities were able to find plenty of able men to run the city who had never held office in the Confederate government (Cox 1994:18).

In post-war years Alamo Plaza became more important to the city. In 1871, after another wrangle with the Catholic church over ownership, the city bought and demolished the ruins of the "low barracks" which had been the south gate and adjacent buildings in mission times and a jail in later years (Fox et al. 1976:21-22). In 1876 the army moved out of the Alamo and into the new facilities at Fort Sam Houston (Story 1938:45). The main post office was moved to Alamo Plaza in 1877 (Cox 1994:22). In June of that year, the Catholic church decided to sell all its remaining property in Alamo Plaza, except the land on which the Alamo church itself stood, to Honoré Grenet, a businessman. In addition, they leased the church building to Grenet for 99 years (Story 1938:47-48).

\section{Commercial Period (1876-1896)}

Grenet renovated the convento-adding a wooden exterior and many decorative flourishes, including wooden cannon-to make the building look like a fortress when viewed from Alamo Plaza. In fact, it was a retail and wholesale enterprise, selling groceries and liquor (Story 1938:50). The patio behind the convento was used as a wagon yard, and the buildings constructed around the patio by the army were used as storage sheds. The Alamo church was also repaired, and became a warehouse for his store (Story 1938:49).

The 1877 Sanborn Insurance map shows a small building attached to the southeastern corner of the chapel, between the south transept and the back wall (Figure 10). This map also shows a door leading from the south transept into this room; no other entrance to this room is evident. The symbols on the map indicate that the building was a single story with an iron roof. The map also indicates walls and a door separating the south transept from the rest of the chapel. These walls are not shown in any subsequent Sanborn map. They may be the "two large modern stone piers in the intersection of the transepts and nave which do not belong there" described in City Council Minutes (L:710) from March 1896. It is possible, however, that the map is incorrect in one or several features. For instance, there are no obvious traces in the east wall of the south transept where a door might once have been. Assuming that the 1877 map is correct, the building attached to the outside could have been built either by the army or by Grenet. No other record of this addition is known to exist, nor is anything known about its function.

Grenet's store advertised "Wholesale Grocer and General Commission Merchant, Importer of Wines, Liquors, and Cigar, China, Crockery, Glassware, and Fancy Goods" (Paulus 1939:45). The place was something of a tourist attraction, at least for country folk, and so impressed a young girl from the nearby town of Boerne, that she never forgot it (Paulus 1939:45). 


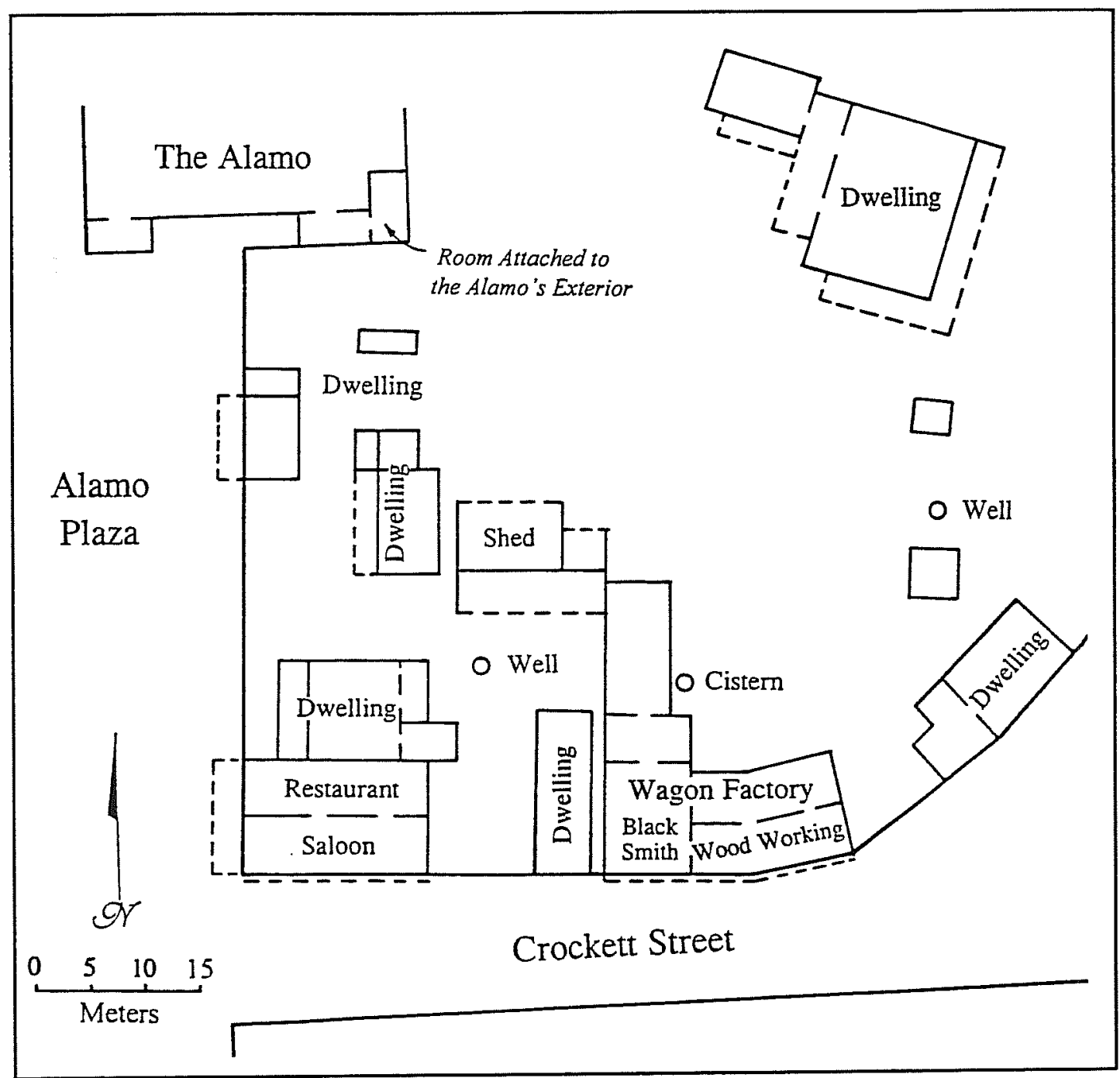

Figure 10. Alamo Plaza in 1877, from an early Sanborn Insurance map. The portion of the map with the northern section of the Alamo church is not available. Note the room attached to the exterior of the south transept and nave.

Not everyone was pleased with "Grenet's Castle." For some, it was a source of amusement (Cox 1994:22), to others the use of the Alamo as a warehouse seemed completely inappropriate. A. J. Sweet, writing, in the style of The Innocents Abroad, of his adventures in Texas around 1880 , pointed out the incongruity of using the Alamo as a grocery warehouse:

While we were inspecting the various portions of the building, the gloom was somewhat increased by the running comments of my guide. "Do you see that angle of the wall, where those old cabbages and those boxes of Limburger cheese are piled? Right there at least forty Mexicans were killed. . . . In this room, where so much soap and axle-grease is stored, seventeen wounded Texans were shot. We have got a soapfactory right here in town: we don't have to send to the North for soap. 'Thermopylae had her messenger of defeat: the Alamo had none.' And it's a darned sight better article than the Yankees make, anyhow. Right here is the most sacred spot in Texas,-and it would bring sixty dollars a month if it was rented out for a saloon,-around which the sacred memories of the past cluster [Sweet and Knox 1905:291]. 
The idea that the site of the ultimate sacrifice of Travis, Bowie, and Crockett was now a commercial enterprise did not sit well with many others. Eventually, in 1883, the Texas legislature decided that the Alamo chapel should be purchased by the state; on May 12, 1883, the Catholic church transferred title to the state for the price of $\$ 20,000$ (Bexar County Deed Records [BCDR], Bexar County Courthouse, San Antonio, Texas, 31:265-267). The city of San Antonio agreed to assume upkeep of the building (Story 1938:54).

\section{The Shrine Period (1883-Present)}

Honoré Grenet died in 1882 and, in 1885, his heirs sold the property to Charles Hugo, Gustav Schmeltzer, and William Heuerman, also retail and wholesale grocers. The Alamo church, now state property in the custody of the city, was a tourist attraction, but was also used for storage (see Figure 2 for a photograph from this period; note the saloon next door). The building was crowded by commercial enterprises (Figures 11 and 12). By 1885, the little building on the southeastern corner was gone, but in 1878 a police substation was constructed on the south side of the chapel in the recess formed between the baptistry and the transept (CCM L:733, April 13, 1896). The walls of the old church formed three walls, with a stone south wall and roof completing the structure (Figure 12). The jail which had been in the buildings associated with the south wall of the old mission had been torn down the year before (Cox 1994:19). The new police station provided improved police presence in an increasingly busy part of San Antonio.

For several years after the city of San Antonio took possession of the Alamo chapel, it was used for storage. A custodian was hired and a few minor repairs made, but in general the city resisted the request of many public-spirited citizens to do more (San Antonio Daily Express [SADE], 3 February 1896). The location of the Alamo chapel in such close proximity to saloons and other commercial properties was seen as both distasteful and a fire hazard.
At last, prompted by both the governor and the superintendent of public buildings, the Committee on Markets, Parks, and Public Buildings was asked to look into the situation. Their report stated, "the Alamo, which is visited daily by strangers passing through this city, is, in its neglected condition, a reproach to us who are its custodians for the State of Texas" (CCM, L:708). They recommended nine steps be taken to remedy the situation:

1st- That the election paraphernalia, such as voting booths, trestles, tables, etc. now stored in the Alamo be immediately removed therefrom to the basement of City Hall.

2nd- That the canvass signs, mottoes, etc. which disfigure the interior and all other similar rubbish be removed from the building under instruction from your committee.

3rd- That hereafter nothing be placed on exhibition in the building without the consent of approval of a committee consisting of the Chairman of the Committee on Markets, Parks and Public Buildings, and a member each of the Alamo Monument Association and the Historical Society.

4th- That from, and after this date, no person or persons whatever shall be permitted to sell souvenirs, pamphlets, photographs or anything else in the Alamo, or on the sidewalk in front or on land in connection with the Alamo and belonging to the State of Texas.

5th- The custodian, who receives a month salary from the city to take care of the property, shall hereafter neither ask nor receive fees from visitors to the Alamo.

6th- If considered advisable to do so, a neat but modest contribution box with suitable inscription may be placed in an unobtrusive location and the key given to some reputable citizen, so that any visitor who might desire to do so, can conveniently donate to a fund to be used only for Alamo purposes. 


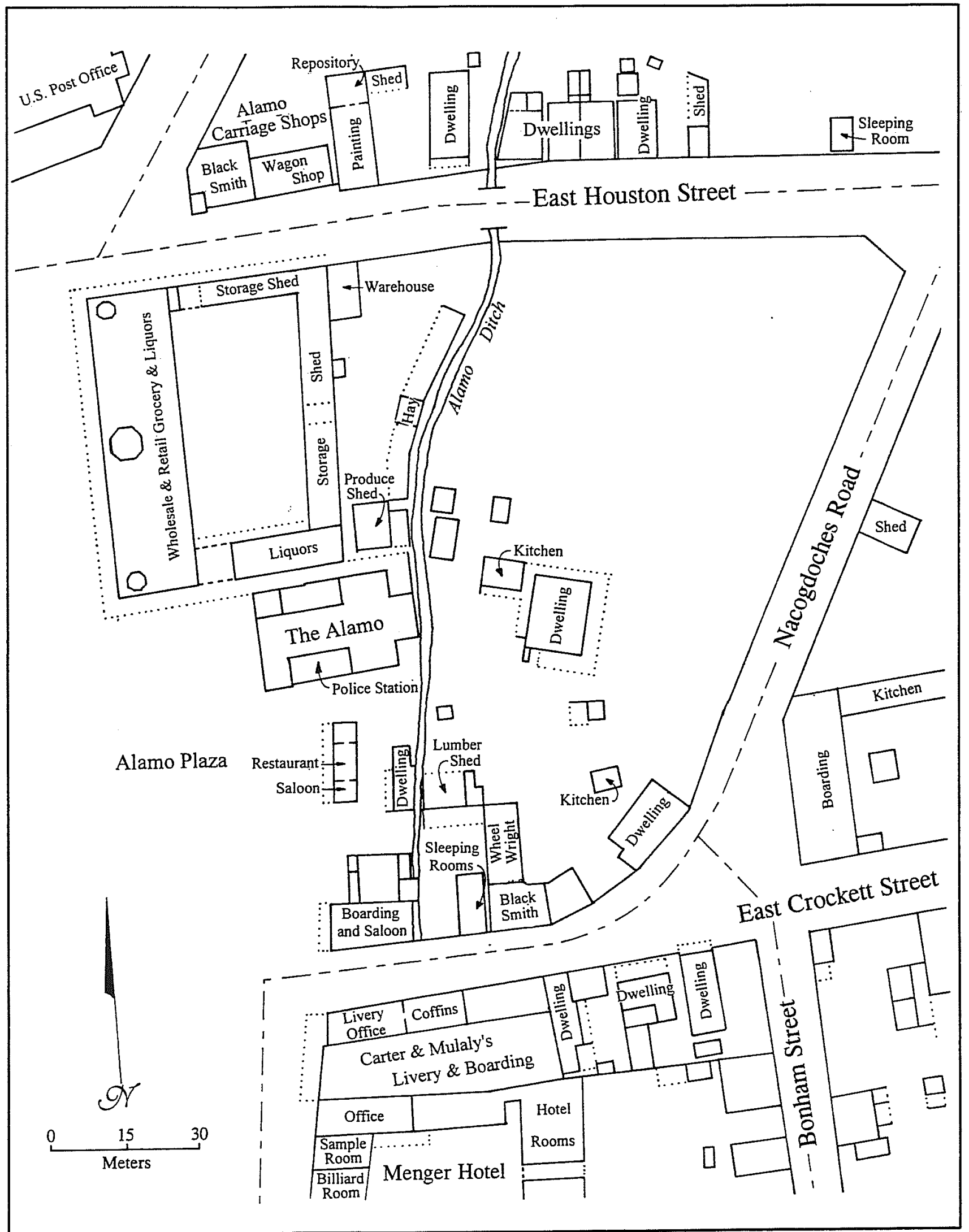

Figure 11. The east side of Alamo Plaza in 1888. Adapted from Sanborn Insurance Maps. 


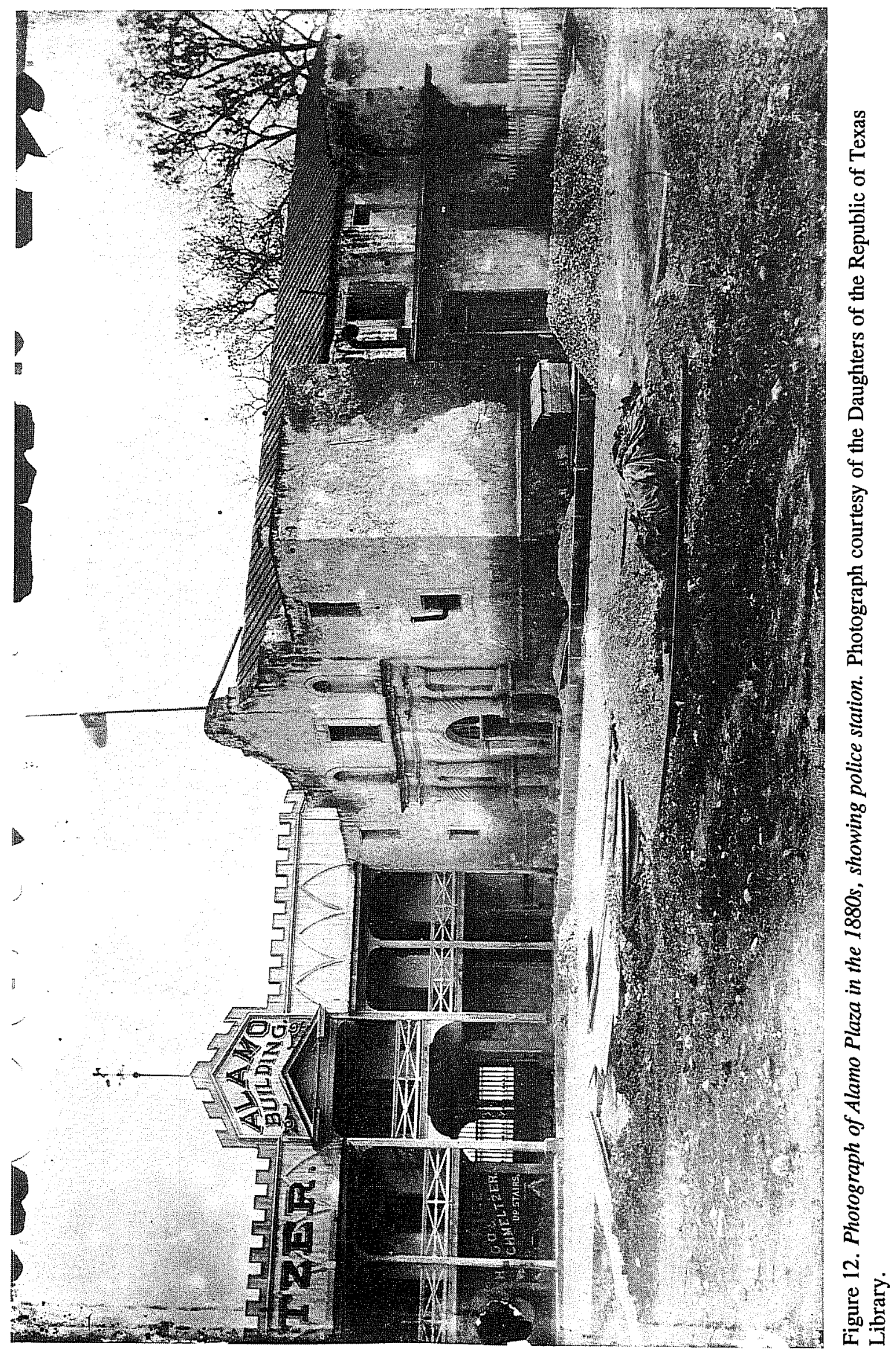


7th- That a committee, such as referred to under section 3 , be authorized to formulate and submit to the council for approval, a set of rules governing the use and custody of the building and that these be presented, framed and hung, in a conspicuous place in the Alamo.

8th- We recommend the His Honor the Mayor take immediate steps looking into the absolute and immediate removal of the present police station from the south side of the Alamo, and razing the addition made for that purpose some years since.

9th- That he, also, communicate with the Government of the State to ascertain how much land the State owns outside the actual grounds occupied by the building, with a view of eventually getting the Alamo disconnected from all adjoining buildings and thus diminishing the danger of destruction by fire, and in the event the State does not own any land surrounding the Alamo, the Governor be requested to take such action as will lead to the earliest purchase by the State sufficient around the Alamo to practically isolate it [CCM, L:708-710].

When asked where the money needed to implement these recommendations was to be found, the chairman of the committee acknowledged the difficulty, but added, "it is a very costly patriotic thing, but I guess any other town in the State would be glad to have it" ( $S A D E, 3$ February 1896).

Money for part of the project was supplied by such public-spirited citizens as the Reverend Doctor G. Q. A. Rose, pastor of the Protestant Episcopal Trinity Mission on Laurel Avenue (San Antonio City Directories 1895-1896, 1896-1897). In early April, the Committee on Markets, Parks, and Public Buildings recommended that the street commissioner be instructed to "immediately tear down the annex [police station] . . . and cart away the debris" (CCM, L:733).
No sooner had the work begun than orders arrived for it to stop. Several coats of whitewash were being removed from the walls with steel brushes and the seams pointed with cement. Several prominent citizens, including a former mayor, objected that the work would "destroy rather than restore" the structure. The governor sent a letter of instruction to the state superintendent of public buildings, telling him to begin investigations of allegations that portions of the original surface were being "so changed as to amount to desecration" (SADE, 5 April 1896, 6 April 1896). In the mean time, the chairman of the Committee on Markets, Parks, and Public Buildings had changed his mind on one point and advised that the police station be retained as "a stand for vendors of souvenirs of the Alamo" (CCM, L:759).

Eventually the differences were resolved and the contract was completed by the latter part of May (CCM, L:774-775). For the first time, the city of San Antonio began to take its obligation to the historic building seriously.

\section{The DRT Takes Over}

The Daughters of the Republic of Texas had been officially organized on November 6, 1891. Membership in the DRT was limited to the female descendants of persons living in Texas before and/or during the revolution that freed the state from Mexico (Story 1938:61). Their stated purpose was to preserve the heritage of the state, and to arouse in all Texans a sense of duty toward the preservation of historic landmarks and documents (Story 1938:61). One of the major goals of this quickly growing organization was to care for the Alamo (Story 1938:62).

By 1904 this goal was in serious jeopardy. Continuing commercial development of Alamo Plaza made the property on which the convento sat very valuable (Figure 13). It was, in fact, about to be sold to an out-of-state syndicate wishing to build a hotel, taking advantage of the historic significance of the site. Many in San Antonio believed that such development on Alamo Plaza was for the good of the 


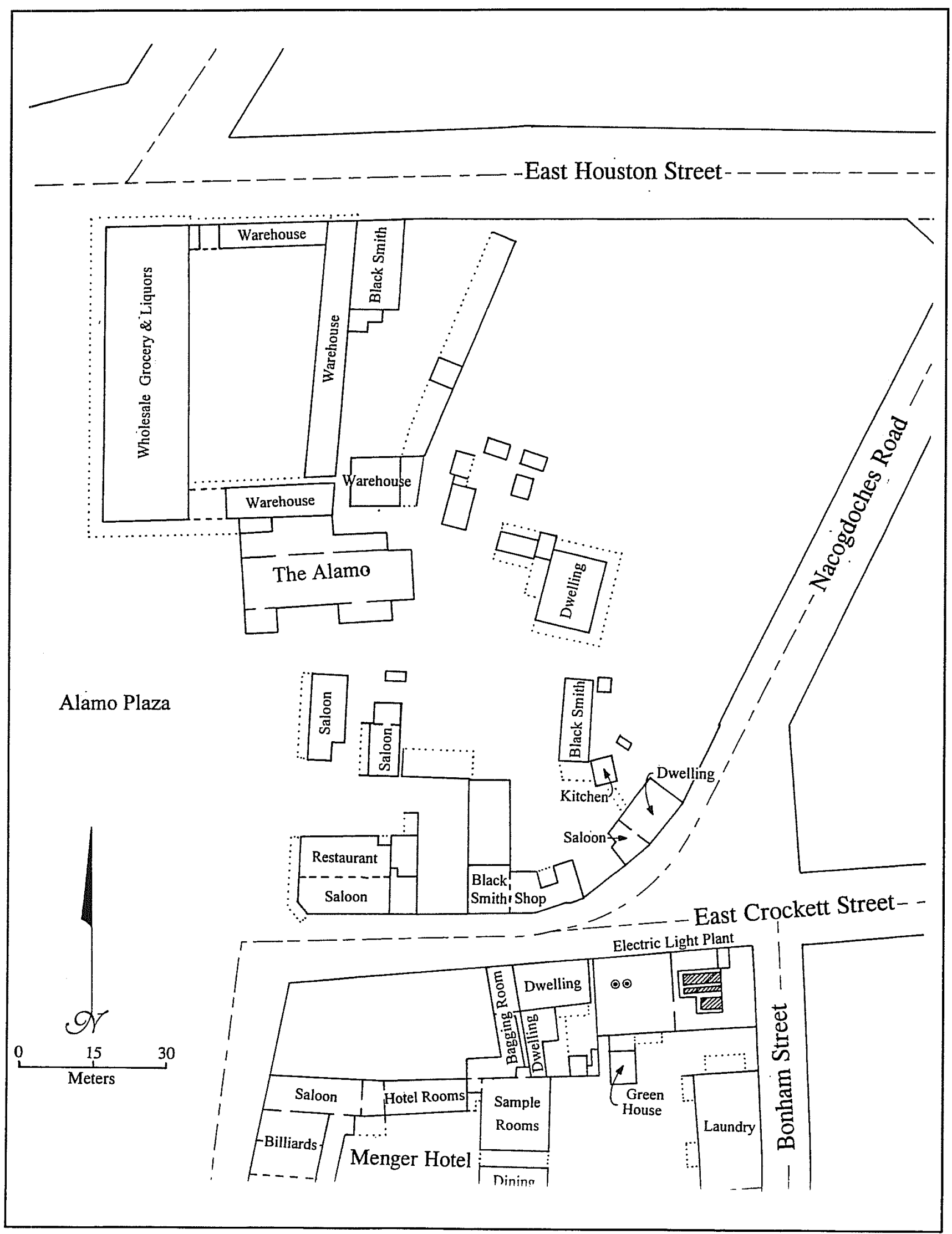

Figure 13. The east side of Alamo Plaza in 1904. Note the absence of the police station and the electric plant on East Crockett Street. 
city (Story 1938:63). However, in February 1904, the convento property was sold to Clara Driscoll, with the following condition:

It is distinctly understood and agreed that this property is purchased by Clara Driscoll for the use and benefit of the Daughters of the Republic of Texas, and is to be used by them for the purpose of making a park about the Alamo, and for no other purpose whatever [BCDR 223:261].

Within the DRT were two factions. One wanted to clear the old convento grounds and make a park, with appropriate monuments. The other wanted to restore the convento grounds to a condition similar to that of 1836 (Story 1938:83). The division became serious, leading to a schism in the DRT. In 1908 the lease with Hugo and Schmeltzer expired, and attorneys for both sides in the DRT agreed to turn over the property to the state, temporarily, until the matter could be settled (Story 1938:88). By 1910 the schism had healed, and it had been agreed that the grounds were to be restored (Story 1938:92). It was a reunited DRT that now faced governor $\mathrm{O}$. B. Colquitt, who had developed his own plan for restoring the Alamo and the convento (Story 1938:95-96). This plan included removing not only the wooden superstructure built by Grenet, but also the upper floor of the convento. He got $\$ 5,000$ dollars appropriated, and had workmen begin tearing down the wooden superstructure.

The DRT did not approve and, in February 1912, passed a resolution to resume trust of the Alamo (Story 1938:105). The governor refused to back down, the DRT filed an injunction, and during the next year, while control of the Alamo was decided in court, all work stopped (Story 1938:109-111). The Texas Supreme Court handed down a decision in June 1913 instructing the governor to spend the $\$ 5,000$ dollars on restoration of the Alamo buildings, but that once the money was spent, the DRT retained control (Story 1938:118).

The DRT resumed the restoration and, by Fiesta week in April 1914, a great deal of work had been done to make a park, incorporating the governor's work (Story 1938:120). They retained a custodian, and in 1920 replaced the roof of the church (Story 1938:122). During 1931 and 1932 the state bought property around the Alamo, and in 1936 the United States government granted money for restorations and purchase of the remaining private property on the east side of Alamo Plaza between Houston and Crockett streets. In addition to the building of a museum north of the church (completed in 1938), a lead roof was laid over the church, and the interior of the church was paved with flagstone (Story 1938:129). During the paving project, four burials were disturbed in the center of the nave (Proceeding of the 46th Annual Meeting of the Daughters of the Republic of Texas, pp. 51-52). At first, many were convinced they were the remains of men killed during the siege and battle in 1836 (SADE, 5 January 1937). The custodian of the Alamo had the dirt from the burial area screened, looking for buttons or other items which would identify the age of the burials (SADE, 6 January 1937). Four months later, after examination by various doctors and anthropologist J. E. Pearce, the remains were declared to be "Caucasian," representing two adults and a child, but how long they had been there was not determined. The remains were reinterred and a bronze plaque placed over the burial site (SADE, 12 May 1937).

During the 1937 renovations, a concrete replica of the old acequia which ran behind the church was constructed above the stone work of the original (Daughters of the Republic of Texas 1995:2). The monument known as the Cenotaph, situated in Alamo Plaza in front of the convento, was finished in 1940, amid considerable controversy (Cox 1994:30). A few relatively minor improvements and conservation efforts in and near the chapel were made between 1938 and 1984. In 1955 a lawn sprinkler system was installed, in 1960 the chapel was air conditioned, in 1970 the sprinkler system was upgraded, and the building was re-pointed several times (DRT Library 1994:3-5). The restoration and conservation efforts which sparked the current project are a continuation of the efforts to preserve the Alamo buildings. 


\section{Conclusion}

The original mission and civilian town were strategically placed between northern Mexico and east Texas. That strategic value continues to this day. It has always been a mixed blessing for San Antonio, which served as way station for trade, but also became an important target in various wars which were fought in the eighteenth and nineteenth centuries (Table 1). The Alamo church has served many functions during the 250 years of its existence, though most of its fame is related to the siege and battle of 1836 . Its history is, in some part, the history of Texas and the history of the varied peoples who have made Texas their home.

Table 1. Chronology of Major Events Which Directly Impacted the Alamo

\begin{tabular}{|c|c|}
\hline Date & Event(s) \\
\hline May 1,1718 & Founding of Mission San Antonio de Valero at original site near San Pedro Springs \\
\hline May 4, 1718 & Founding of the Villa San Fernando de Béxar and Presidio San Antonio de Béxar \\
\hline $1719-1724$ & $\begin{array}{l}\text { Mission moved to location south of current location, small church and other buildings } \\
\text { constructed, acequia construction began }\end{array}$ \\
\hline$\overline{1724}$ & Hurricane destroys mission buildings, new site on current location chosen \\
\hline 1720 & Mission San José y San Miguel de Aguayo established south of Mission Valero \\
\hline 1731 & $\begin{array}{l}\text { Three east Texas missions moved to San Antonio River south of Mission Valero, renamed } \\
\text { Mission Nuestra Señora de la Purísima Concepción de Acuña, Mission San Juan Capistrano, } \\
\text { and Mission San Franciso de la Espada }\end{array}$ \\
\hline May 8, 1744 & Cornerstone of new church at Valero laid \\
\hline August 1744 & $\begin{array}{l}\text { Master stone mason Antonio de Tello ordered arrested for murder, takes refuge in temporary } \\
\text { church near half-completed walls of Valero church, disappears a few days later }\end{array}$ \\
\hline 1750 & Estimated year in which church was completed and then collapsed \\
\hline 1751 & Arrival of new master stone mason and continued construction of church \\
\hline 1758 & Date on keystone over main door of the new church \\
\hline 1789 & $\begin{array}{l}\text { Fray López reports construction of church stopped after some of the arches for the domed } \\
\text { ceiling had been completed, but it was no longer possible to finish the church due to lack of } \\
\text { manpower }\end{array}$ \\
\hline 1793 & Mission San Antonio de Valero is secularized \\
\hline 1801 & $\begin{array}{l}\text { Arrival of Segunda Compania Volante de San Carlos de Parras del Alamo, which uses the old } \\
\text { mission grounds as a garrison. The uncompleted church serves as part of the pharmacy for the } \\
\text { hospital, the first in San Antonio }\end{array}$ \\
\hline September 16,1810 & The beginning of the Mexican Revolution led by Father Hidalgo \\
\hline January 21,1811 & $\begin{array}{l}\text { Garrison at the Alamo rebels, captures royal governor and other royalists (Garrett } \\
\text { 1968[1939]:40) }\end{array}$ \\
\hline March 2, 1811 & Town retaken by royalists \\
\hline March 11, 1811 & $\begin{array}{l}\text { Viceroy declares that the Villa San Fernando, the Presidio San Antonio, and the grounds of } \\
\text { the old Mission Valero are all to be incorporated together under the name San Antonio de } \\
\text { Béxar }\end{array}$ \\
\hline March 1813 & $\begin{array}{l}\text { Army of Mexican rebels and American adventurers takes San Antonio, Governor Salcedo } \\
\text { murdered }\end{array}$ \\
\hline August 1813 & Royalists retake San Antonio, retribution on town causes severe depopulation \\
\hline 1821 & Mexico gains freedom from Spain \\
\hline October 1835 & Open revolt against Mexico begins in Texas at Gonzales \\
\hline
\end{tabular}


Table 1. continued

\begin{tabular}{|c|c|}
\hline Date & Event(s) \\
\hline December 1835 & Battle of Béxar, in which Texan rebels take town and garrison at the Alamo \\
\hline $\begin{array}{c}\text { February- } \\
\text { March } 1836\end{array}$ & Siege of the Alamo; on March 6, Alamo taken, all defenders killed. \\
\hline April 1836 & Battle of San Jacinto, Santa Anna captured, signs treaty, nation of Texas established \\
\hline April 1842 & San Antonio, including Alamo, taken and sacked by Mexican Army \\
\hline December 29,1846 & Texas becomes part of the United States \\
\hline April 1846 & Mexican War begins \\
\hline 1850 & $\begin{array}{l}\text { U.S. Army leases Alamo church and convento to use as Quartermaster's Corps depot, } \\
\text { renovates both buildings, cleans out church, builds famous cap on the facade, and places the } \\
\text { first roof on the church }\end{array}$ \\
\hline February 1861 & Texas State Convention votes to secede from the Union \\
\hline February 16, 1861 & $\begin{array}{l}\text { General Twiggs surrenders all U.S. Army property, including the Alamo and its contents, to } \\
\text { representatives of the state }\end{array}$ \\
\hline 1861 & $\begin{array}{l}\text { Interior of church gutted by fire. Confederate Army rebuilds and continues using the building } \\
\text { as a Quartermaster's warehouse. }\end{array}$ \\
\hline $1865-1876$ & U.S. Army again uses Alamo as a Quartermaster's Corps depot. \\
\hline 1877 & $\begin{array}{l}\text { Convento sold to Grenet and Alamo church leased to him. Alamo church is used as a } \\
\text { warehouse for Grenet's grocery store. }\end{array}$ \\
\hline 1878 & Police Station built on south side of chapel. \\
\hline 1883 & Alamo church becomes property of the state of Texas \\
\hline November 1891 & DRT formed \\
\hline 1896 & Police station removed from south side of chapel. \\
\hline 1904 & Convento and surrounding grounds purchased for the DRT by Clara Driscoll \\
\hline 1905 & Alamo and grounds are entrusted to the DRT by the state \\
\hline 1913-1914 & Restoration of Alamo grounds by governor of Texas and DRT \\
\hline $1936-1938$ & $\begin{array}{l}\text { Extensive renovation of buildings, purchase of more land, reconstruction of a part of the } \\
\text { acequia, and construction of the museum building to the north of the church are undertaken, } \\
\text { partially funded by a federal grant }\end{array}$ \\
\hline 1940 & Cenotaph monument completed in Alamo Plaza \\
\hline
\end{tabular}




\section{Chapter Three}

\section{Previous Excavations}

$\mathrm{T}$ This chapter presents a brief description, in chronological order, of the seven previous archaeological excavations conducted on the grounds of the Alamo Shrine. Figure 14 shows the locations of these projects.

In 1966, during installation of buried electrical lines, numerous artifacts were discovered and a project was begun in seven areas within the courtyards (Figure 14). Excavations took place in June and July 1966 (Greer 1967). Large numbers of artifacts from the eighteenth to twentieth centuries were recovered. Several features were identified as the remains of Colonial-period architecture, including the foundation of a single-room structure made of adobe in the well courtyard. A flagstone floor apparently related to mission-period workrooms was also uncovered, as was an adobe pavement in the convento courtyard, the footings of the walls separating courtyards, and the remains of the additions to the convento made by Grenet. Profiles consistently indicate a layer of packed caliche associated with mission-period artifacts overlaid by a layer of light-grey matrix with artifacts from the later Spanish period (Greer 1967).

During August and September 1970, in anticipation of the construction of a new wing on the north side of the DRT's Texas History Research Library (Sorrow 1972), excavations were carried out north of the building (Figure 14). Although most of the excavation profiles show multiple and repeated disturbances of the subsurface sediments, portions of the Alamo acequia and part of the foundation of a brick building were uncovered. Remnants of a packed caliche "veneer" were noted in several units. The acequia was lined with limestone on the sides and red brick on the bottom, the latter indicating that the construction of this new lining in the old acequia took place after 1877 when the railroad began bringing brick into San Antonio. The west side of the acequia was apparently destroyed when the above-mentioned brick building was built (Sorrow 1972).

In March and April 1973, before landscaping the north patio in 1973, excavations were carried out (Figure 14), revealing the remains of four rooms against the east wall of the courtyard (Schuetz 1973). Schuetz attributes a packed caliche level found to some extent throughout the excavation to the Quartermaster's Corps period. Artifacts beneath this layer date to the Colonial period (Schuetz 1973).

In 1977 a plan to replace part of the flagstone paving at the front of the Alamo church made excavations necessary (Figure 14). The excavations extended to the base of the foundation, some $1.4 \mathrm{~m}$ below the paving. Eaton (1980) discovered the remains of a trench associated with the palisade fortification built by General Cós in 1835 (see Figure 6). The trench extended from the south end of the facade toward the southwest to the "Low Barracks," i.e., the buildings at the original south gate of the mission (Figure 6). This trench contained numerous battle-period artifacts. Two layers of packed caliche were excavated, both of which had been cut by the palisade trench, revealing the caliche had been in place before 1835 . One of these levels began approximately $20 \mathrm{~cm}$ above the top of the foundation, while the other was found about $3 \mathrm{~cm}$ below the first (Eaton 1980:56). 


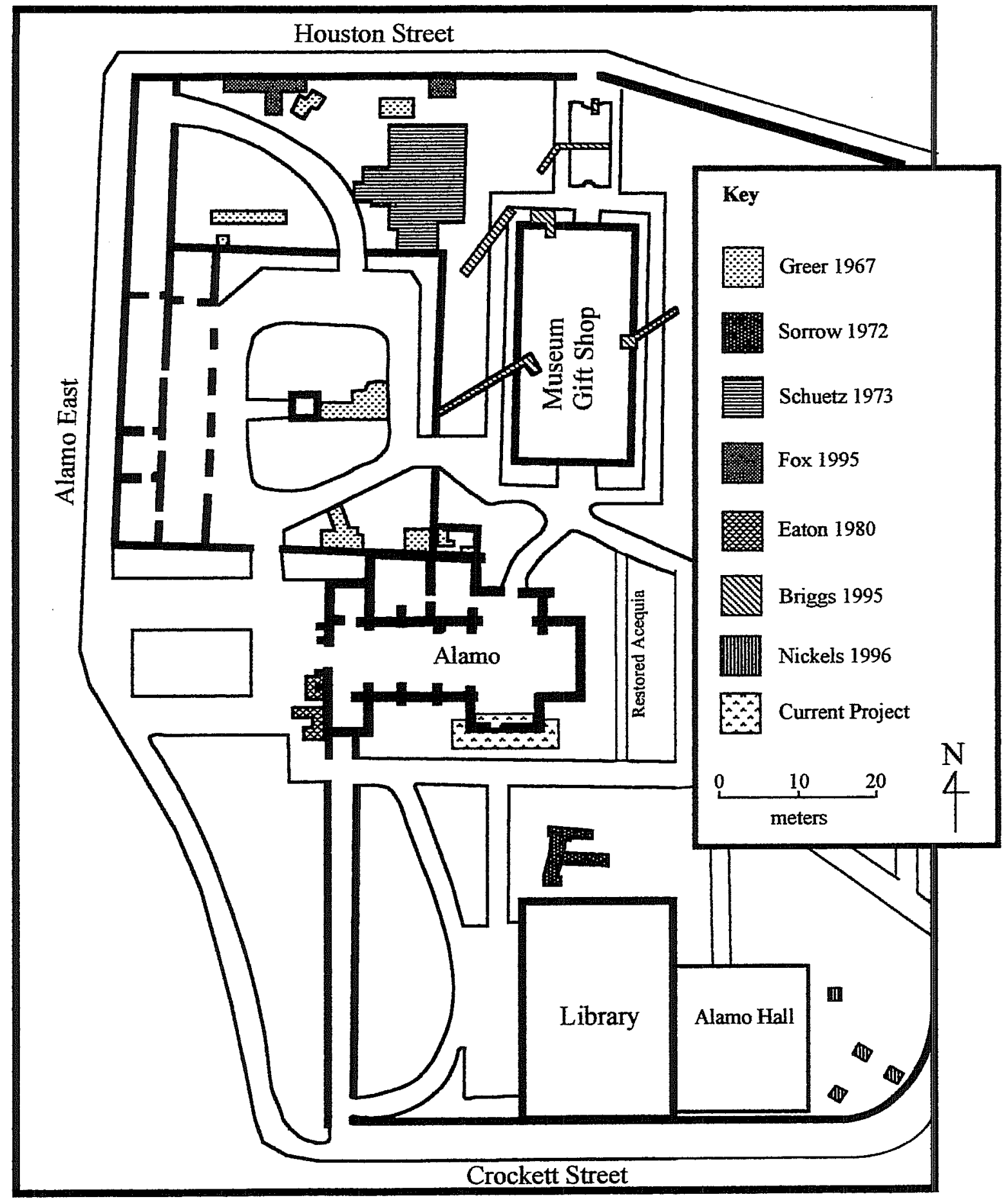

Figure 14. Previous excavations at the Alamo Shrine. Adapted from Fox 1994:53. 
In March 1979 (Ivey and Fox 1996), a project was initiated at the request of the DRT, who were planning to rebuild the wall along the north side of Alamo park, adjacent to Houston Street (Figure 14). Test excavations carried out at that time and again in February 1980, revealed a sequence of wall construction in the area, and a trench, probably part of General Cos's defensive works (see Figure 6), running east-west. Within the fill of this trench a human skull was recovered. Remains of an adobe foundation were also documented (Ivey and Fox 1997).

Late in 1979, the DRT began a project to fix drainage problems around Alamo Hall (Nickels 1997). The latter houses the DRT Library, meeting rooms, and administrative offices. The project entailed building an underground drainage system and re-grading the ground surface. These activities would necessitate disturbance of sediments to the east of the hall. In January 1980, four test units were placed by a CAR field crew to locate the remains of the home of a former mayor of San Antonio, Wilhelm Carl August Thielepape (1814-1904). The house was believed to have been demolished in 1936-1937, at the time of the extensive building and landscaping projects carried out by the DRT. The test units were placed to confirm the location of the foundation of the Thielepape house, including its detached kitchen (note the location of the dwelling in Figure 13). The test units found stone foundations supporting the remains of adobe walls at a level about 18 inches below the ground surface. The sediments around and within these walls were highly disturbed by the construction and later demolition of the house. Artifacts dating to the prehistoric period, the Spanish colonial occupation, and the nineteenth and twentieth centuries were recovered in highly mixed contexts (Nickels 1997).

In 1991 a series of test trenches and excavations was made necessary by plans for asbestos abatement and renovation of the Alamo Museum and Gift Shop, constructed in 1936, north of the church (Briggs 1993). Tests under the floor of the building revealed disturbed strata. Further test units associated with the asbestos abatement and three backhoe trenches were also dug (Figure 14). Numerous artifacts from the eighteenth to twentieth century were recovered, and several adobe foundations probably associated with Colonial-period workrooms and Army-period storage sheds were discovered (Briggs 1993). 


\section{Chapter Four \\ Methodology}

7 he primary purpose of these archaeological investigations was to insure that no undisturbed 1 cultural deposits were damaged by restoration work until the information they contained was accurately recorded. The scope-of-work originally stated that the cutting of the stone wall and insertion of the metal plates would require exterior excavations to extend approximately $1.8 \mathrm{~m}(6 \mathrm{ft})$ out from the wall, to an approximate depth of $60 \mathrm{~cm}(2 \mathrm{ft})$. The interior excavations would also extend about $1.8 \mathrm{~m}(6 \mathrm{ft})$ out from the back wall but only about 5-10 $\mathrm{cm}$ (2-4 inches) below the existing floor (Figure 15).

\section{Exterior}

Prior to the beginning of exterior investigations, the section to be excavated was outlined with rebar and string under Peterson's direction (Figure 16). The section was then divided into three areas: A, B, and C (Figure 17). The landscaping gravel was removed with shovels by the construction crew under CAR supervision. The southwestern corner of the south transept was designated the horizontal datum for the exterior excavations. A vertical datum set at ground surface was used during the excavations, and later compared to the datum on the exterior of the front of the Alamo (see discussion of the interior).

Two 50-x-50-cm test units were laid out in Area $C$ to determine the extent of disturbance present along the outer wall. These units were dug by hand in $10-\mathrm{cm}$ arbitrary levels to a depth of $55-60 \mathrm{~cm}$ below the ground surface (bgs) and all sediment was screened through $1 / 4$-inch mesh. Both units were later expanded

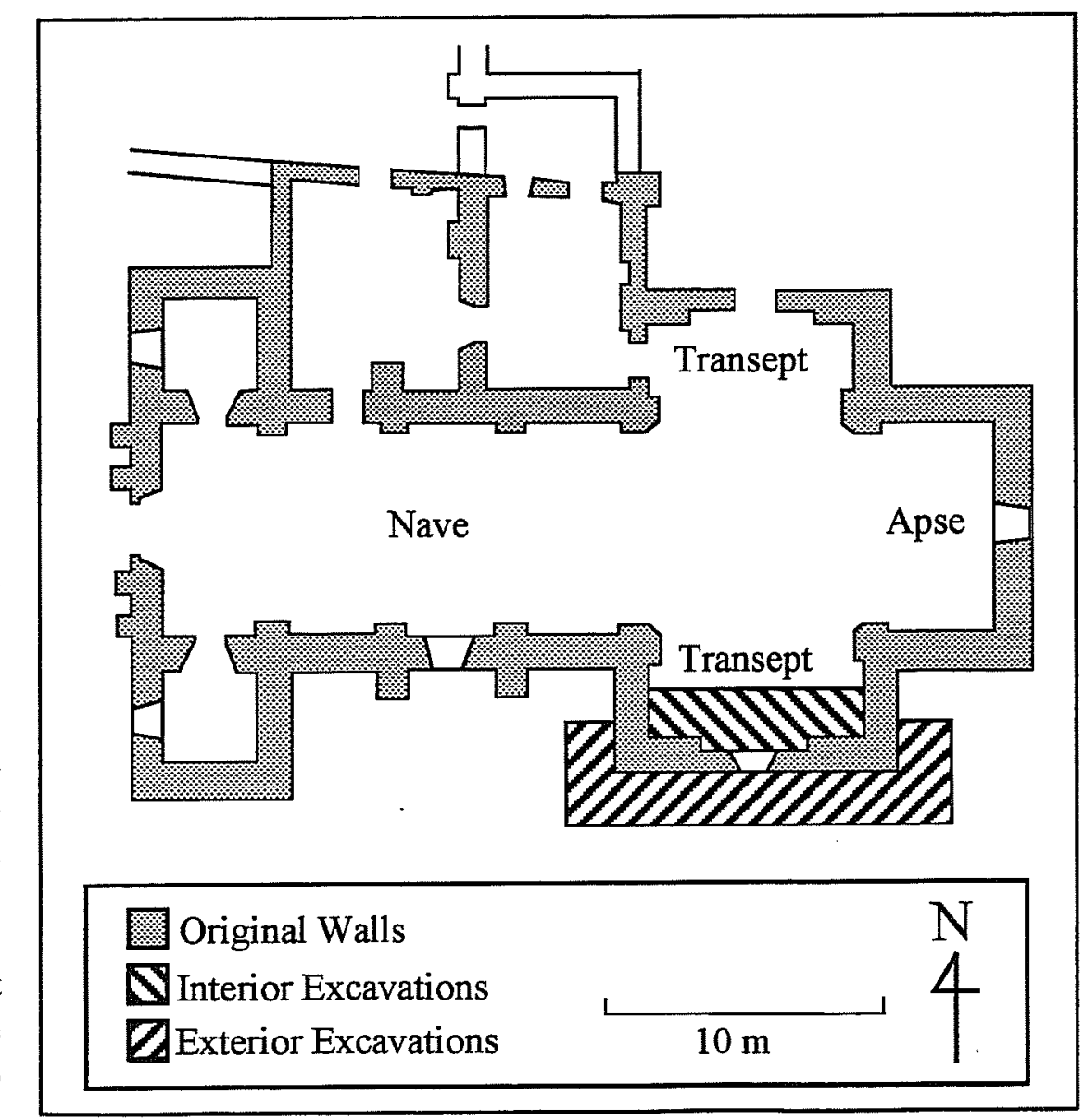

Figure 15. Plan view of the Alamo, showing areas to be excavated. 


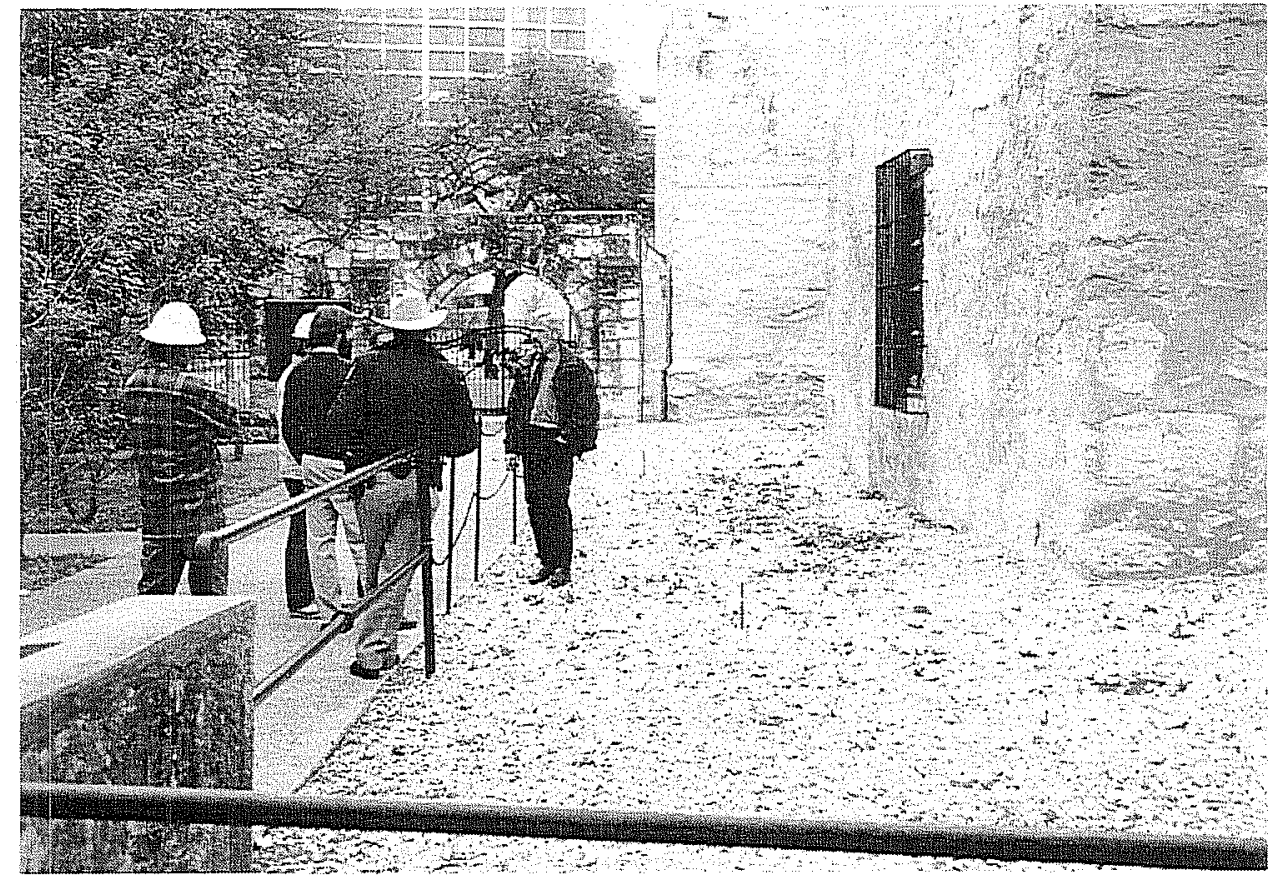

Figure 16. Area of exterior excavation, before project, looking west.

closely monitored by CAR personnel (Figures 18 and 19). Any artifacts noticed during the sediment removal were collected, however the sediment was not screened.

As archival research indicated that at different times in the past two small buildings had been attached to the exterior of the southern wall of the Alamo, sediment removal in Areas $A$ and $B$ proceeded cautiously. When a foundation was discovered in Area A, the shovel excavation was stopped at the level of the

to $1 \times 1 \mathrm{~m}$. After careful consideration of the information gained in the two test units, we decided, in consultation with the DRT and THC archaeologists, to dig the remaining Area $\mathrm{C}$ sediments with shovels. This work was done by the construction crew and top of the foundation. The rest of the deposits, down to the level of the Alamo foundations, were removed by hand excavation. When a concrete foundation was discovered in Area B, a 1-x-1-m test unit was placed inside the foundation (Figure 17). When this unit

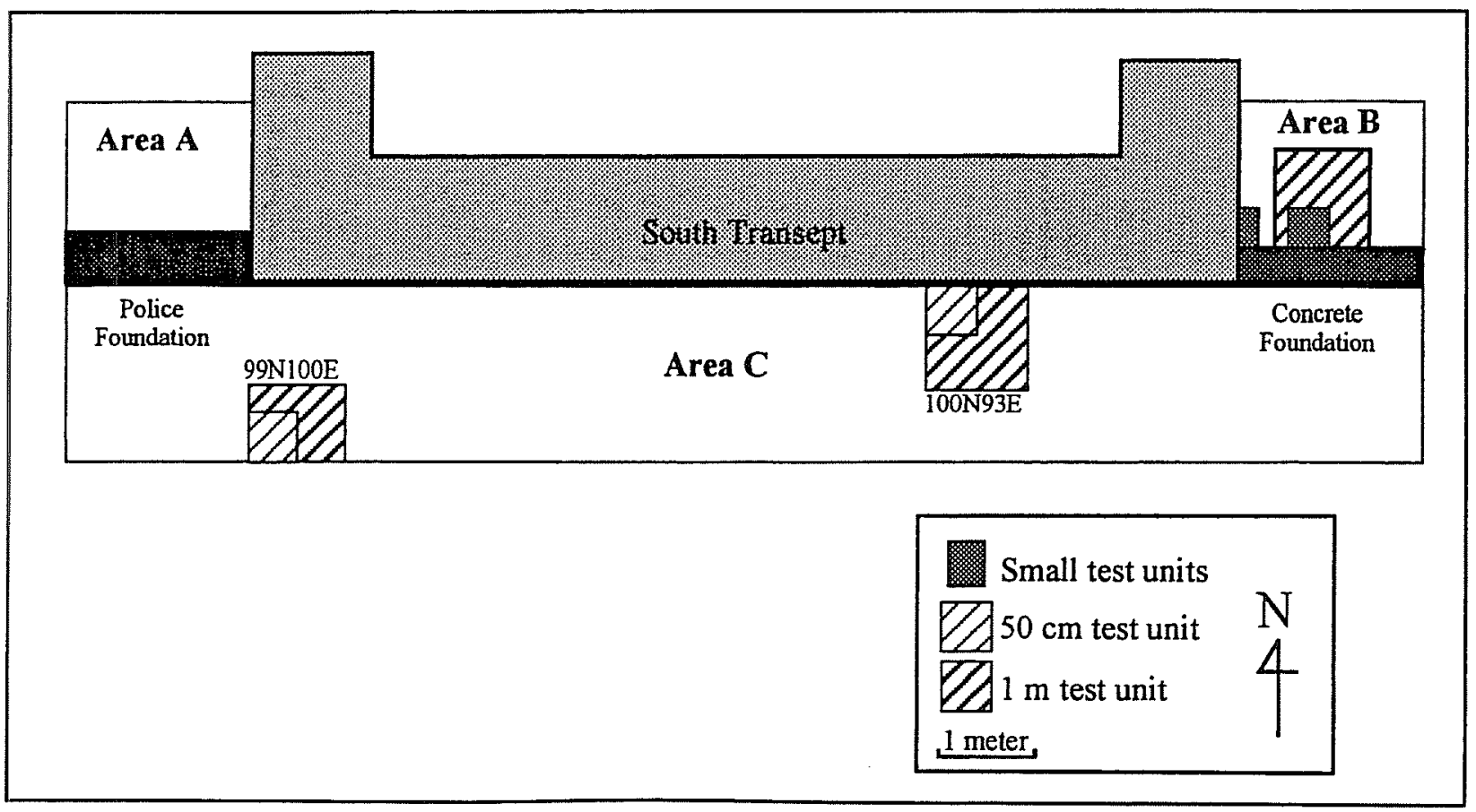

Figure 17. Location of test units in exterior excavations. 


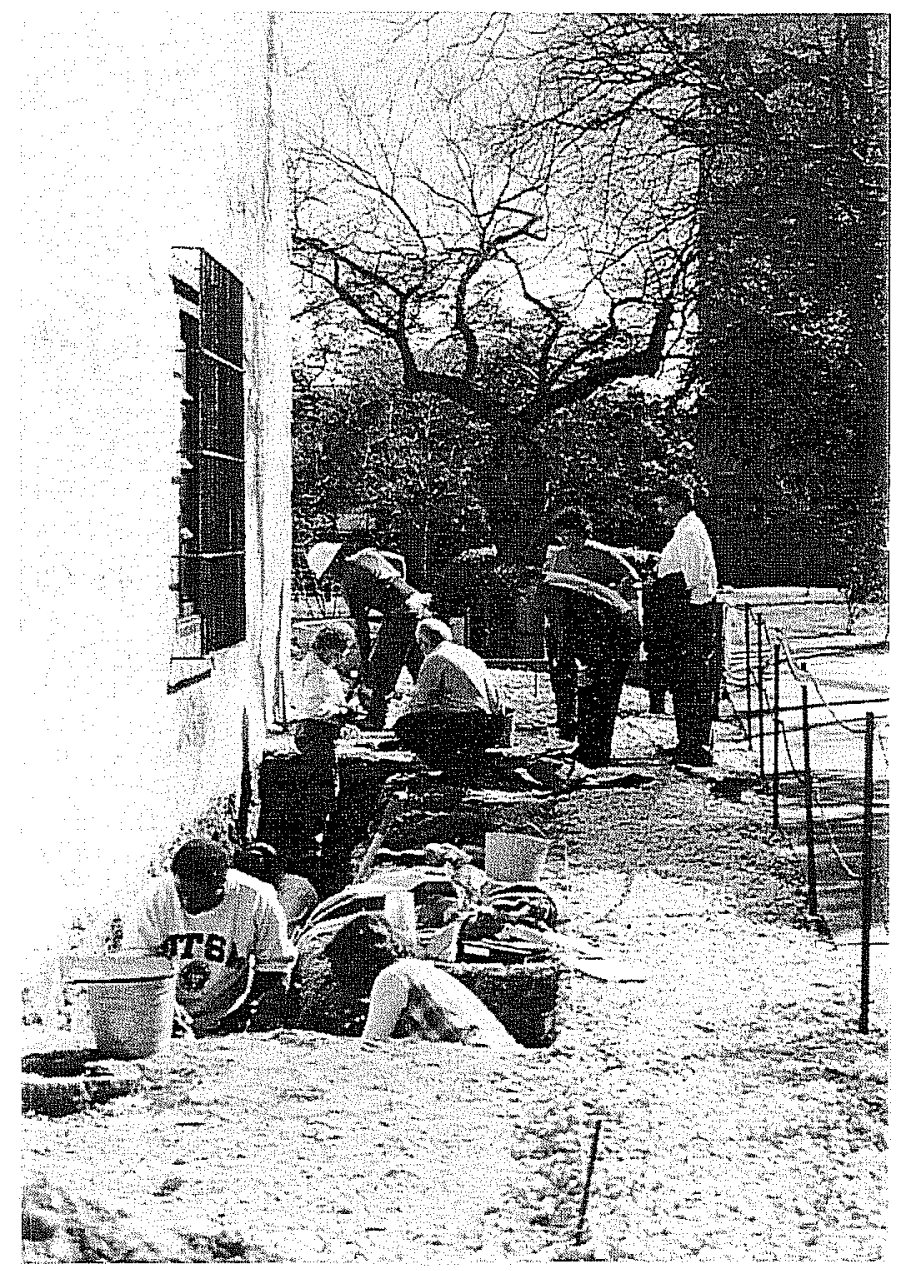

Figure 18. Exterior excavations, looking east.

CAR personnel in the foreground are clearing caliche surface by hand while worker shovels near Area B in the background.

showed that the sediments in Area B were also disturbed, at least to the level of a brick pavement found at the same level as the top of the concrete foundation, the remainder of the sediments were removed by shovel. A soil change was noted about 55 $\mathrm{cm}$ bgs. From this point, excavation down to the required depth was continued by hand.

Due to the disturbed nature of the sediments in the test units, the construction crew removed most of the remaining sediments in Area C. CAR personnel monitored this procedure and stopped the shoveling at a level just above the top of the Alamo foundation. Artifacts noticed during shoveled excavations were collected and bagged by area, but the sediments were not screened.

\section{Monitored Excavations}

When the original target excavations were completed, no decisions had yet been made concerning what should be done about the two foundations to the east and west of the transept. Eventually, the DRT and the THC decided to leave the foundation in Area A intact except where its removal was necessary to facilitate the wall cutting. In the case of the east (concrete) foundation in Area $B$, there was concern that the structure was impeding water flow away from the building, and thus contributing to the moisture problems in the walls of the Alamo. After consultation with the project architect and the THC, the DRT decided to uncover the concrete foundation, record it, then remove it. This was done in May 1995, by the construction crew with CAR archaeologists present

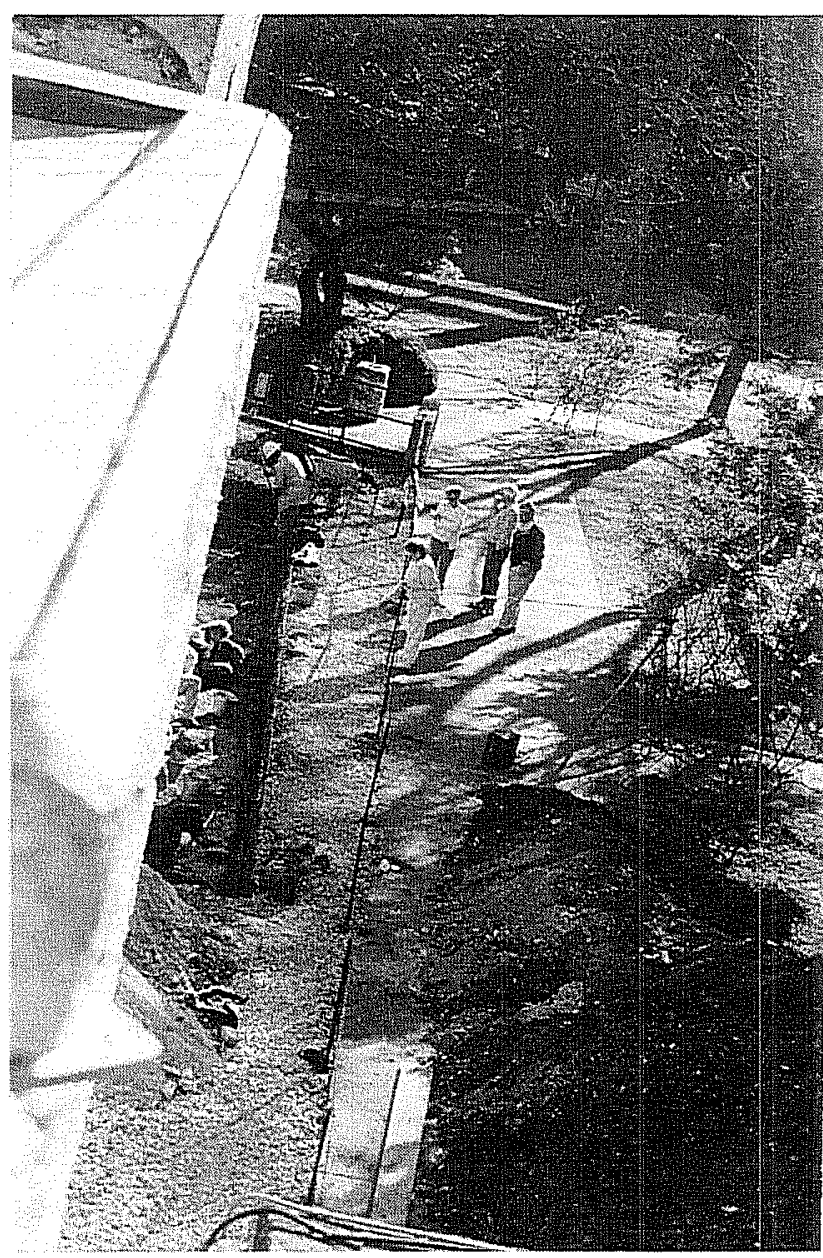

Figure 19. Photo of exterior excavations taken from the roof of the Alamo, looking southeast. 
to monitor and record any features (Figure 20). The foundation was exposed by shovel, cut into sections about $40-50 \mathrm{~cm}$ thick with a power saw, and removed.

In June 1995, additional excavations, monitored by $\mathrm{CAR}$, occurred along the east wall of the south transept. These excavations allowed the placement of a plastic water barrier against the wall. Work began at the area excavated in February and continued to the corner of the south wall of the apse, then to the back (southeast) corner of the apse (Figure 20). These excavations were approximately $60 \mathrm{~cm}$ wide and $60 \mathrm{~cm}$ deep.

\section{Interior}

The excavations in the interior were considered especially important, since this was the first time archaeologists systematically excavated inside the Alamo chapel. The cultural deposits in the interior of the Alamo had been protected under a cement slab and flagstone paving since 1937 (Story 1938:129). While it was possible that undisturbed deposits from the eighteenth and nineteenth centuries would be found, it was also possible that these deposits had been destroyed, either by the U.S. Army when they cleaned out the church prior to renovating it in 1850 , or by workmen when the floor was leveled prior to the installation of the cement floor in 1937. That a certain amount of sediment removal occurred in the latter renovation is known, as discussed in Chapter Two (Proceedings of the 46th Annual Meeting of the Daughters of the Republic of Texas, pp. 51-52; see also photograph of excavation of burials San Antonio Light, 5 January 1937). If any undisturbed cultural deposits were discovered during excavation, they could be of considerable value in increasing understanding of the history of the people who used the building.

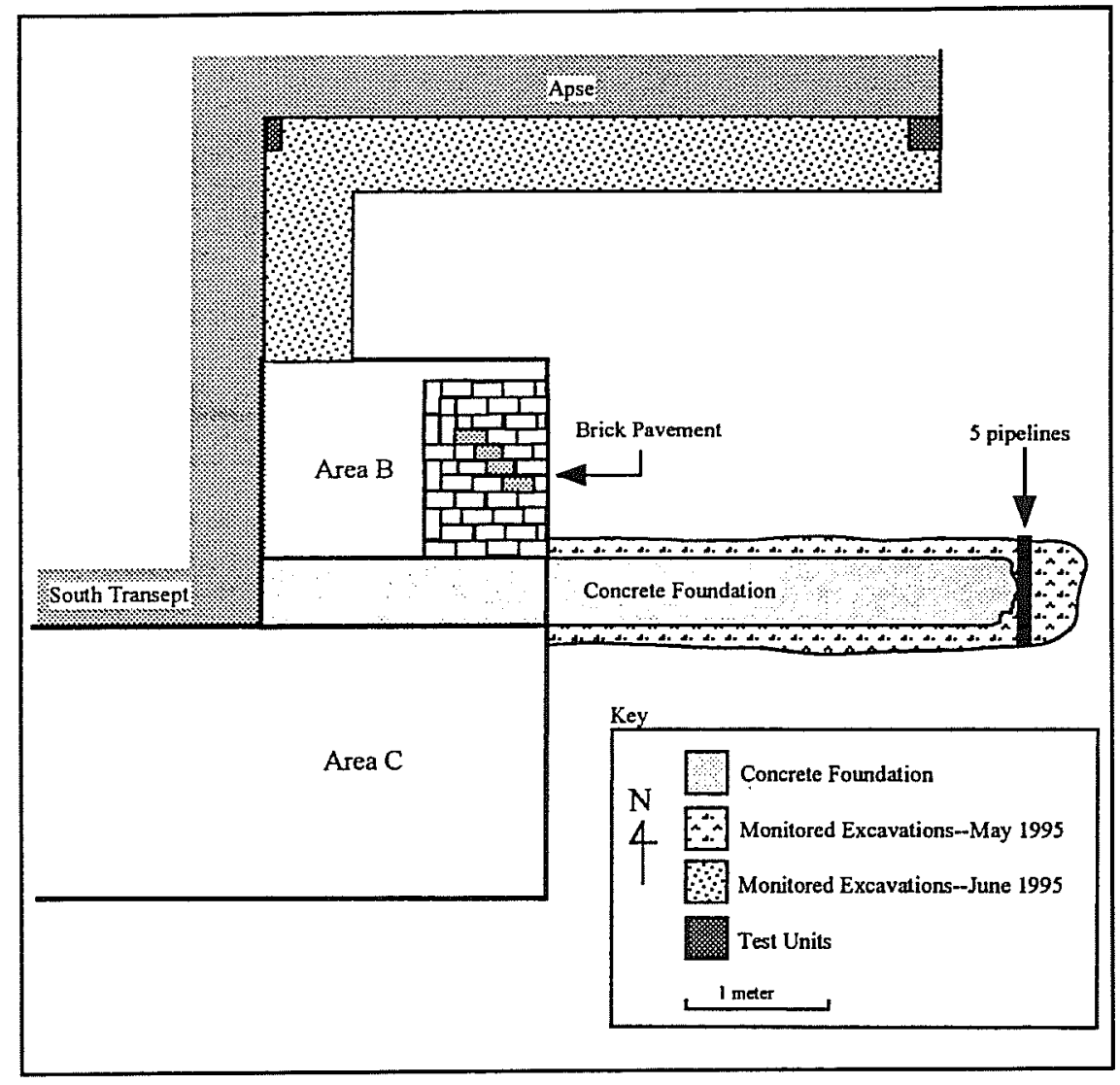

Figure 20. Diagram of Area $B$, north of the concrete foundation, and monitored excavation extensions.

There was also concern that the excavations inside the church might encounter human burials. The men who were killed during the battle in 1836 are known to have been burned in funeral pyres (Fehrenbach 1968:215); however, the practice of burying people in the floor of churches was common during the Spanish colonial period (Hard 1994; Humphreys 1971; Montgomery et al. 1949:180; Schuetz 1968:213). All such burials which took place during the tenure of the missionaries would have been those of Christians, either Spanish or Indian, as burial of a non-Catholic inside the church would have been a desecration (Montgomery et al. 1949:180).

Previous excavations at other missions in San Antonio resulted in numerous examples of both articulated human remains and individual elements. Human remains were found both in areas believed to have been used as cemeteries and those where burials were not expected (Fox 1970:49; Humphreys 1971; Meissner 1993:31; Rawn 1977:146; Schuetz 1968). 
Burials were often disturbed by subsequent interments, and bones from old graves were apparently pushed aside to make room for the new burials (see Schuetz 1968, especially Figures 25 and 26). Many disarticulated bones and bone fragments, especially appendages, were scattered in the process and finding such remains is very common in Colonial contexts.

The 1749 burial records from Mission San Antonio de Valero relate that Don José Antonio Bueno de Roxas, a prominent Spanish citizen of the nearby Villa de San Fernando (San Antonio), had been buried in the south transept of the "new church" (Leal 1978). Archival research also indicates there had been several human burials discovered by the army in the late 1840 s, when they were clearing the remains of the old ramp and other debris from the interior (Corner 1890:11). As described in Chapter Two, during the paving of the floor in January 1937, several other burials were discovered in the center of the building. Thus we knew burials could be present in the study area, but because of the shallow depth of our excavations, we did not expect to disturb any. CAR proposed that if human burials were encountered during the project,

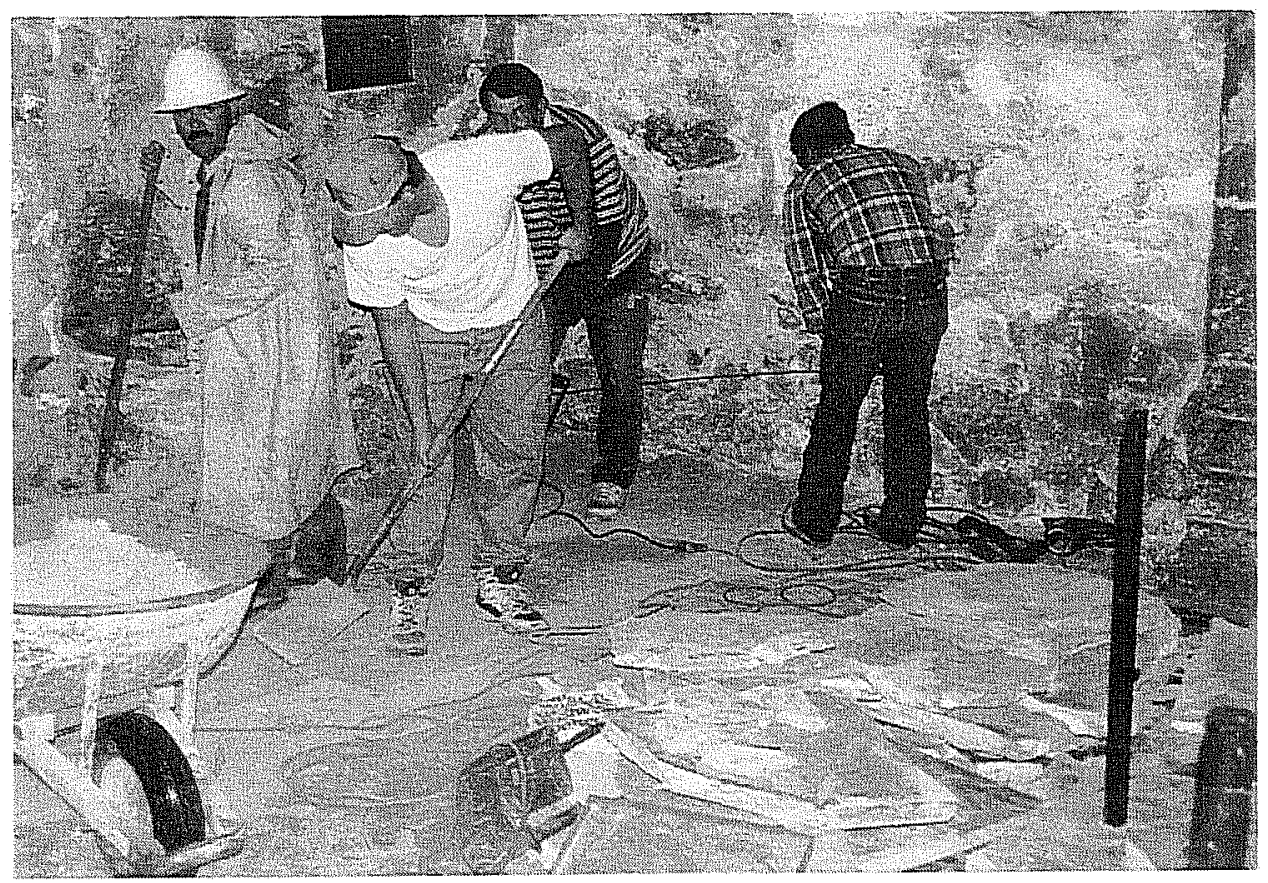

Figure 21. Workers removing the floor on the interior of the south transept. Facing southwest. work would stop until a detailed preservation plan to avoid disturbance of the burial could be designed.

All interior areas were hand excavated and screened through $1 / 4$-inch mesh. Excavations in the interior were limited to a $180-\mathrm{cm}(6-\mathrm{ft})$ band along the southern wall of the south transept. Within this area, the 3-cm-deep flagstone floor was pried up with levers by the construction crew. A layer of loose sand about $5 \mathrm{~cm}$ thick covered a 12 -cm-thick concrete sub floor which was removed with jackhammers (Figure $21)$. The concrete had been poured directly on the ground surface (Figure 22).

The excavated area originally extended approximately one meter out from the south wall and included an alcove approximately $50 \mathrm{~cm}$ deep (Figure 23). This area was later extended $30 \mathrm{~cm}$ to the north, toward the middle of the chapel. The interior southwestern corner of the south transept was used as the horizontal datum for the interior excavations, and given the arbitrary designation of $101 \mathrm{~N} / 100 \mathrm{E}$. Units were designated by the coordinates of their southwest corner in relation to this datum. The vertical datum used during the excavations was the flagstone floor surface in the center of the transept, at the edge of the excavation area. This datum was later compared to the site datum established during the 1975 excavations in Alamo Plaza (Fox et al. 1976), and subsequently used by Eaton during his excavations at the front of the church (Eaton 1980). Although the corner molding which was designated the vertical datum in 1975 had fallen off during the intervening years, the position of the original vertical datum could be reestablished with reasonable accuracy. This was measured in relation to the 


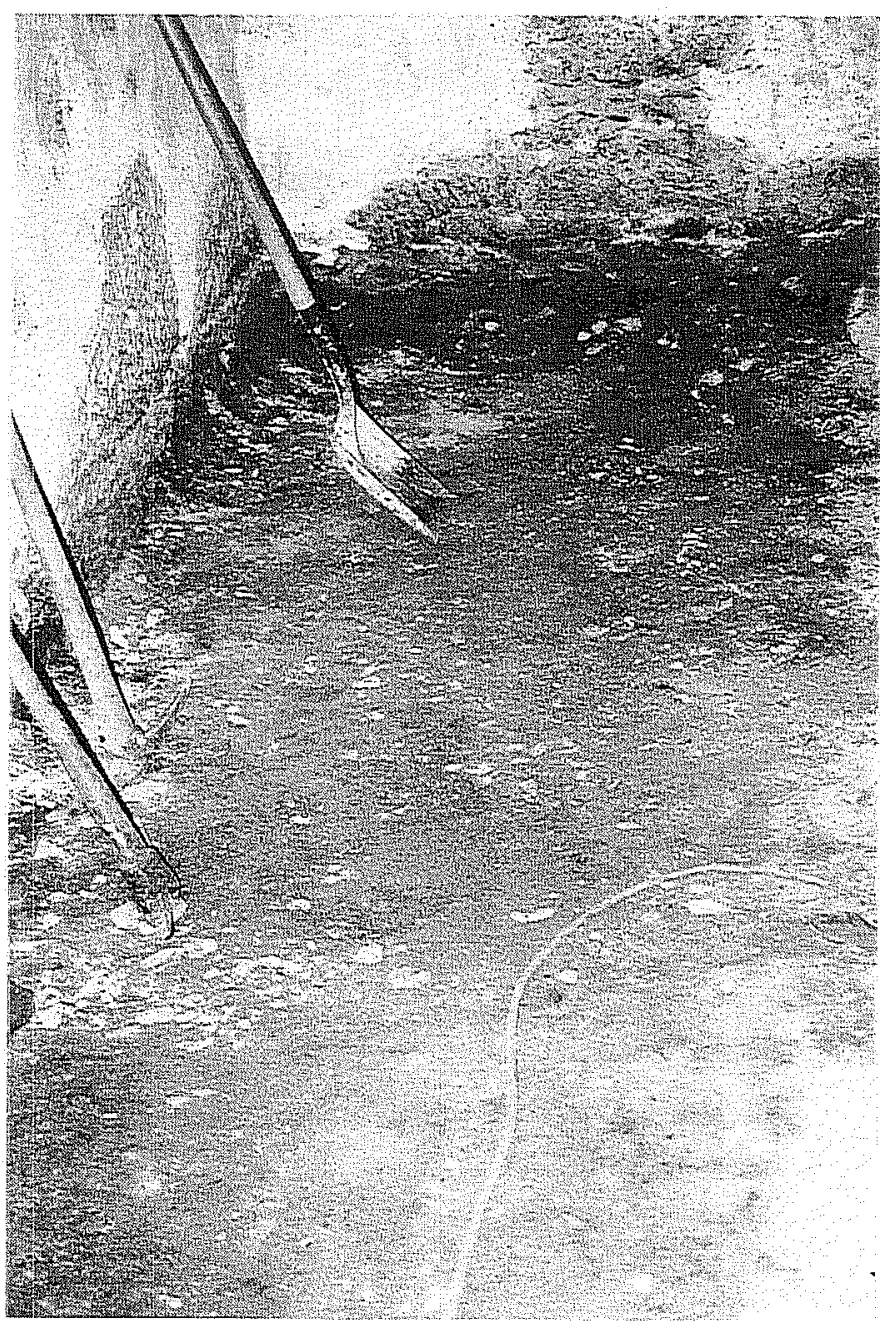

Figure 22. Interior excavation area, showing ground surface after removal of concrete slab.

excavation datum on the floor inside the building, and was found to be $84 \mathrm{~cm}$ above it.

Excavations began in the alcove, and were originally taken to a depth of $122 \mathrm{~cm}$ below datum (bd) in all but unit 101N/96E, which was left to provide an east/west profile. At the southern edge of Unit 101N/95E, at approximately $117 \mathrm{~cm} \mathrm{bd}$, a line of roughly dressed limestone blocks projected out from the wall approximately $8-10 \mathrm{~cm}$ and a similar ledge was found at a level $6 \mathrm{~cm}$ higher in Units 101N99-100E. At first we thought this was the top of the foundation. However, because the foundation directly outside measured $15 \mathrm{~cm}$ lower, a small test unit measuring $20 \times 20 \mathrm{~cm}$ was extended downward in Unit 101N/95E (Figure 23). Twenty centimeters below the top of the first ledge, a second ledge was uncovered which extended $10 \mathrm{~cm}$ further from the wall than the first. This course of stones is believed to be the top of the Alamo wall foundation. The test unit was stopped at a level about 5-6 $\mathrm{cm}$ below the edge of the lower limestone ledge when a layer of compact caliche was encountered.

After examining the ledges, Carolyn Peterson, the project architect, decided that the wall should be cut for the metal plates at $140 \mathrm{~cm}$ bd (Figure 24), at a point just below the top of the lower rock ledge and above the packed caliche. She also decided that the excavated area was too narrow to accommodate the rock-cutting equipment and metal plates. Subsequently, more of the flagstone and concrete floor was removed, and eight new 1-x-.3-m units (Figure 23) were excavated to a depth of $143 \mathrm{~cm}$ bd.

\section{Artifacts and Recording}

Artifacts recovered during the project were bagged according to provenience, and returned to the CAR laboratory for processing and analysis. Processing and analytical procedures are discussed in Chapter Six.

Exposed portions of the chapel wall, both interior and exterior, were illustrated and the excavated portion of the alcove floor was photographed and videotaped. Profiles of interior and exterior excavation units were drawn. Soil columns were taken from both the interior and exterior for micromorphological analysis, the results of which are presented in Appendix A. 

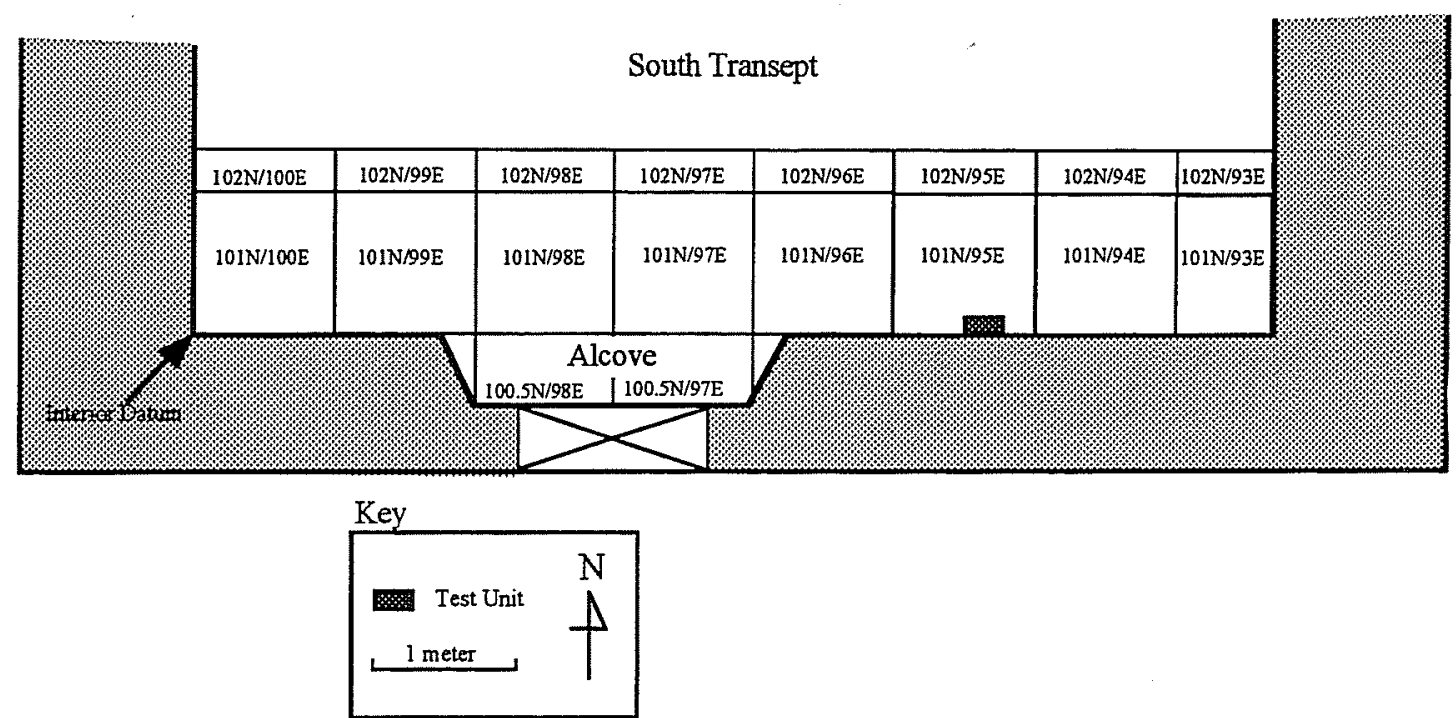

Figure 23. Diagram of interior excavation units.

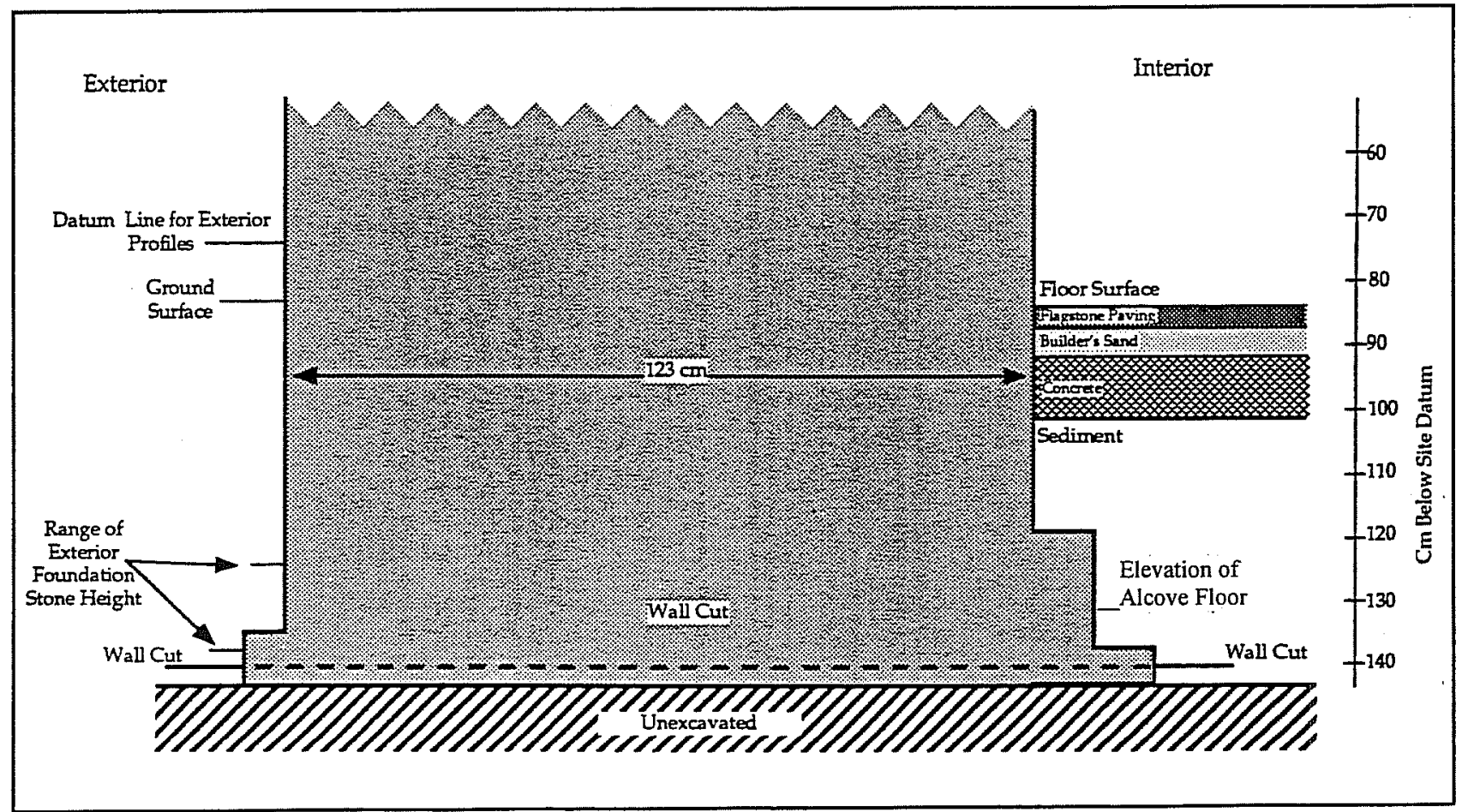

Figure 24. Schematic section through wall of Unit 101N/95E, looking west. 


\section{Chapter Five}

\section{Excavations}

$\mathrm{M}$ ost excavations and monitoring took place between January 25 and February 10 , 1995. Monitoring of the removal of additional recent fill occurred in May and June 1995.

Before excavations began, preliminary work was conducted in the interior and exterior under CAR supervision. In the exterior area a layer of landscaping gravel was removed to expose the ground surface. In the interior the flagstone floor and the cement slab beneath it were removed, revealing the sediment beneath. The results of the excavations of the interior and exterior areas are considered separately.

\section{Exterior Excavations}

Three areas were identified in the exterior excavations: Areas A, B, and C (Figure 17). Discussions with both current and previous grounds keepers suggested that the entire exterior excavation area had been seriously disturbed by various landscaping and utility work (Bill Miller, personal communication 1995; Waynne Cox, personal communication 1995). Three 1-m units were excavated in Area $\mathrm{C}$ to determine the extent of disturbance of the sediments. Three smaller test units were used when considered appropriate (Figure 17).

\section{Unit 99N/100E}

Test unit 99N/100E (see Figure 17) contained between 10 and 90 percent small (pea-sized) gravels mixed with dark gray-brown clay matrix. The few artifacts recovered appeared to be mostly twentieth century in origin, including plastic and wire nails. A few cut nails, commonly used until the end of the nineteenth century (Edgerton 1897:246), were encountered. Near the east wall a layer of black landscaping plastic was uncovered at about $12 \mathrm{~cm}$ bgs and extending down to $28 \mathrm{~cm}$ at the northern corner of the unit. Approximately $20 \mathrm{~cm}$ below the ground surface, the sediment in the southwestern corner of the unit changed to more silt and to a darker grey brown with no pebbles. Further excavations revealed that this was a posthole, which extended into the west wall of the unit and to $50 \mathrm{~cm}$ bgs. A flat piece of soft limestone was at its base. A 1-inch cast iron pipe was encountered in the northern end of the unit at $36 \mathrm{~cm}$ bgs.

A layer of caliche, uncovered $55 \mathrm{~cm}$ below the surface, extended across the entire unit except for the southern-most $10 \mathrm{~cm}$ which was composed of a very soft silty grey brown clay matrix. The southern edge of the caliche was abrupt, and ran roughly parallel to the wall of the Alamo. Although this caliche layer was similar in general characteristics to the Colonial layer described by Eaton (1980) and others (Greer 1967; Schuetz 1973; Sorrow 1972), excavations to a depth of $60 \mathrm{~cm}$ revealed no artifacts. At $60 \mathrm{~cm}$ below the surface, numerous flat pieces of very soft limestone and/or hard caliche surrounded by more caliche were encountered. We believe this to be a prepared surface. The soft silty clay matrix in the southern edge of the unit was found to contain two 3-inch cast iron pipes, lying next to each other at a depth of about $60 \mathrm{~cm}$ bgs. It was clear that the caliche deposit had 
been removed during the trenching operation when the pipes were laid. The excavation was stopped at this point, as the unit had reached the required depth.

To ensure that no undisturbed strata existed in that area, this $50-\mathrm{cm}$ test unit was expanded to a $1-\mathrm{m}$ test unit. The extension was dug by shovel, and the sediment screened. A 1-inch PVC pipe, known to be part of the exterior lighting system for the southern exterior wall of the Alamo, was uncovered about 12 $\mathrm{cm}$ bgs. This test unit demonstrated that the matrix in this area was highly disturbed, probably recently. The east profile of the unit was then extended to the wall of the Alamo by workmen, and the full profile drawn (Figure 25). The excavation showed clearly that the entire area had been repeatedly disturbed by various pipe-laying and landscaping operations.

\section{Unit 100N/93E}

Test unit $100 \mathrm{~N} / 93 \mathrm{E}$, originally $50 \times 50 \mathrm{~cm}$, was placed against the wall of the south transept (Figure 17). The unit had a layer of white landscaping sand along its northern edge, next to the wall. Below this were layers of dark brown clay sediment, with varying amounts of gravel. A lens of very dark black clay with charcoal and small amounts of gravel with tar-coated stones was encountered $30 \mathrm{~cm}$ below surface. Below this level the sediment seemed somewhat less disturbed. The excavation exposed the top of the Alamo foundation at $62 \mathrm{~cm}$ bgs. This foundation consists of irregularly cut limestone blocks with sandy mortar. The foundation protrudes 10 to 20 $\mathrm{cm}$ from the wall. At this same level was a caliche surface similar to, though less compact, than the deposits found in the bottom of Unit $99 \mathrm{~N} / 100 \mathrm{E}$. This

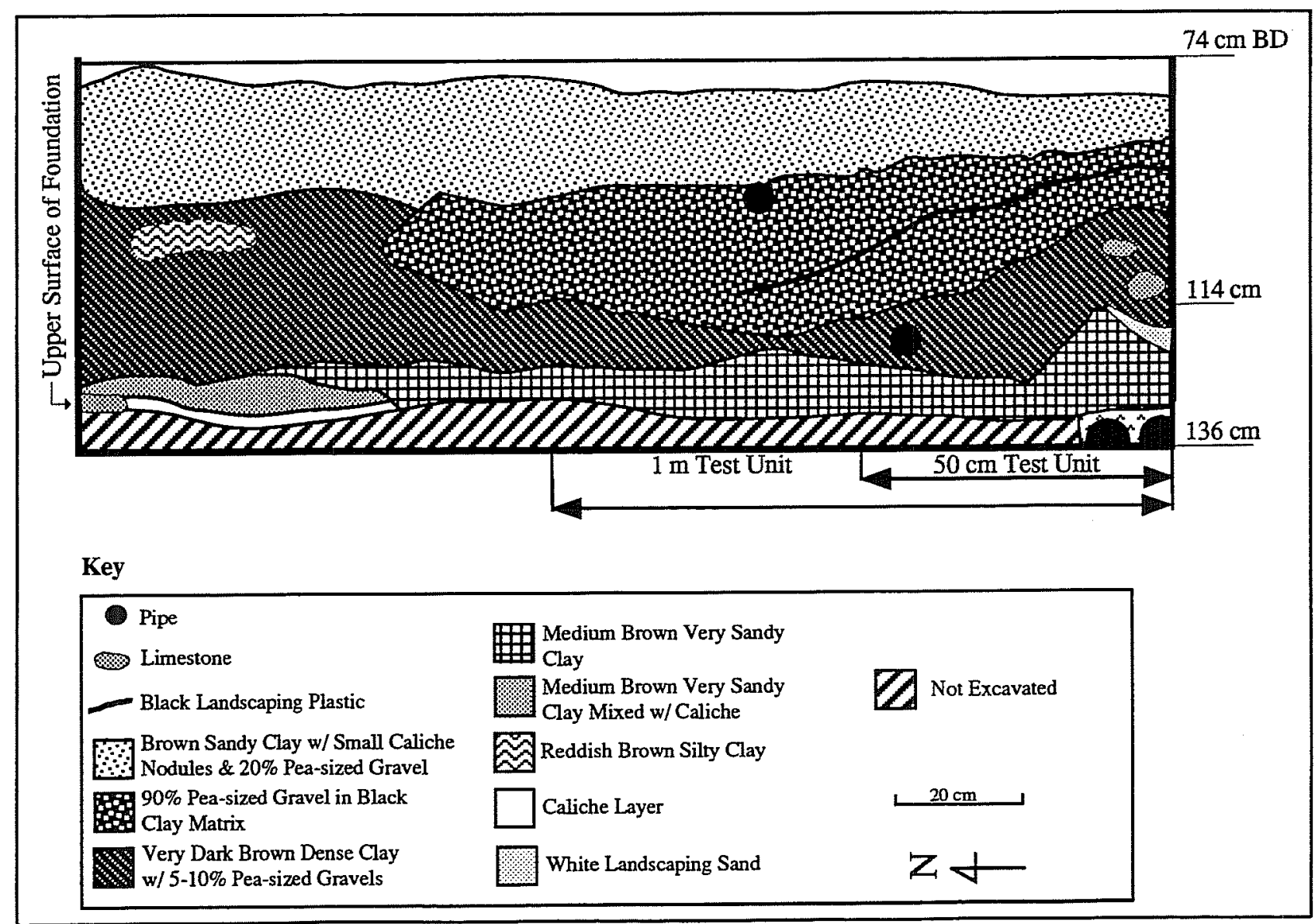

Figure 25. Profile of east wall of Unit 99/N100E extended to the south wall of the Alamo. 
layer only extended a short distance from the foundation at this level (Figure 26). In general, the sediments in this unit appear disturbed, although there does not seem to have been as many episodes of disturbance as in Unit $99 \mathrm{~N} / 100 \mathrm{E}$.

The test unit was subsequently expanded to a full 1-x-1-m unit. The extension was dug with shovels and the sediment screened. The enlarged unit

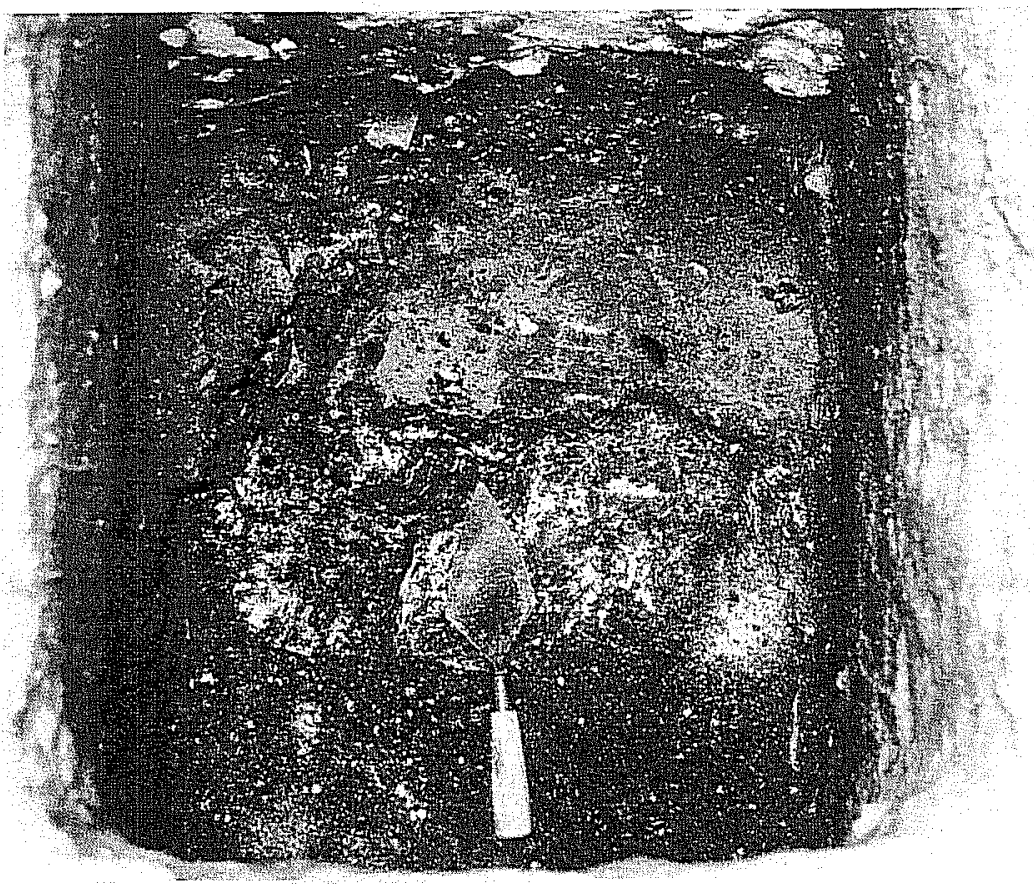

Figure 26. The bottom of Unit 100N/93E, showing the foundation of the Alamo. The trowel is pointing north, toward the wall of the Alamo. yielded nineteenthand twentieth-century artifacts to a depth of $65 \mathrm{~cm}$. Shoveled Excavations The packed caliche surface was found in a few small patches.

Area A

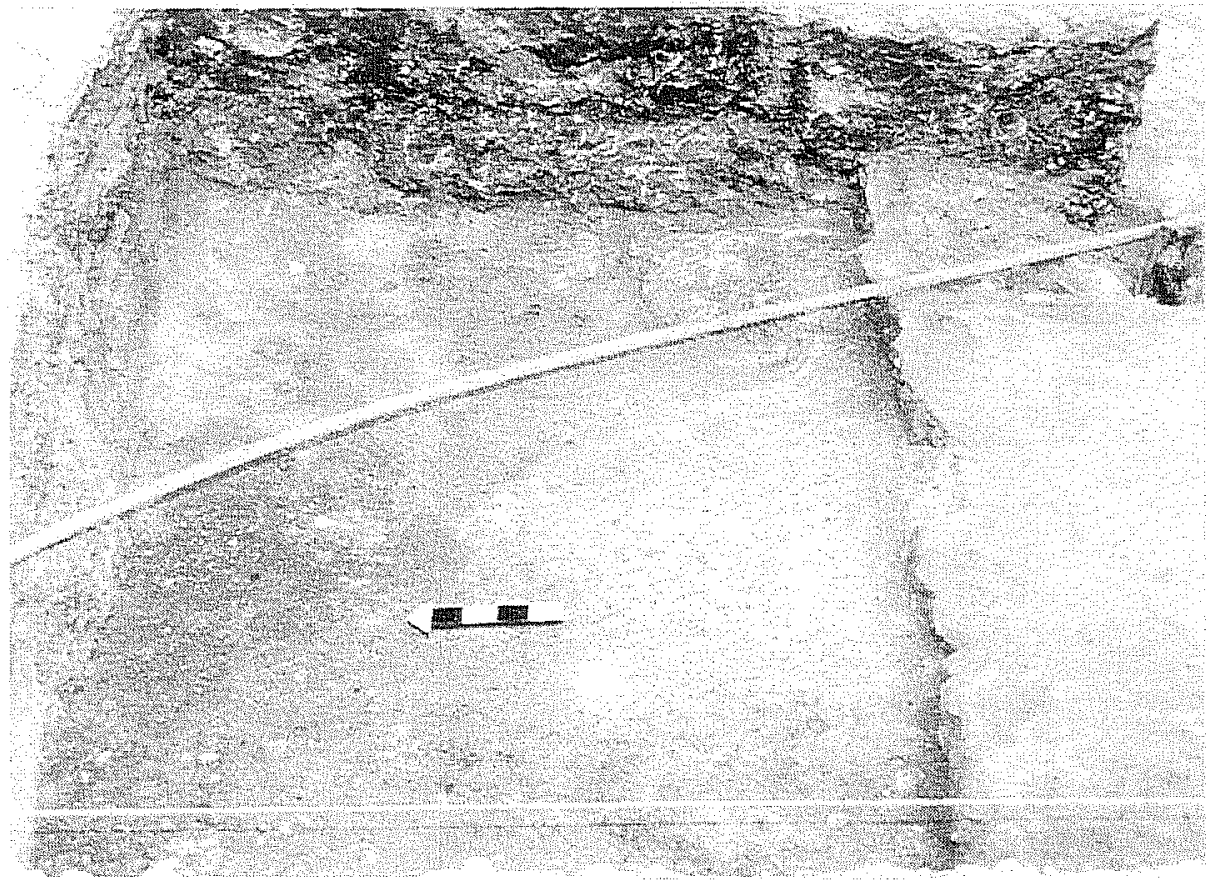

Figure 27. Area A, looking east, with rubble foundation shown on the right side. The foundation of the west wall of the south transept is at the top.

During the excavation of Area A, a foundation was uncovered at the west corner of the south transept (Figure 17). This foundation consisted of a mixture of limestone rubble, red-brown clay, and caliche formed into a rectangular shape, $87 \mathrm{~cm}$ across, extending below the level of the excavations (Figure 27). This foundation is believed to be the remnant of the police station attached to the outside of the Alamo between the south transept and the south tower (baptistery), between about 1885 and 1904 (see Figures 11 and 12). A vertical cedar post set into this foundation was found near the 
west corner of the south transept (Figure 28). In the dirt fill around the cedar post a silver coin was discovered, which was later determined to be a Civil War-period German coin (see Chapter Six).

Deposits in Area A, i.e. inside the police station, were more obviously disturbed than those in other parts of the exterior excavations. Numerous layers of sediment with varying colors and amounts of gravel were present (Figure 29). Beneath these disturbed

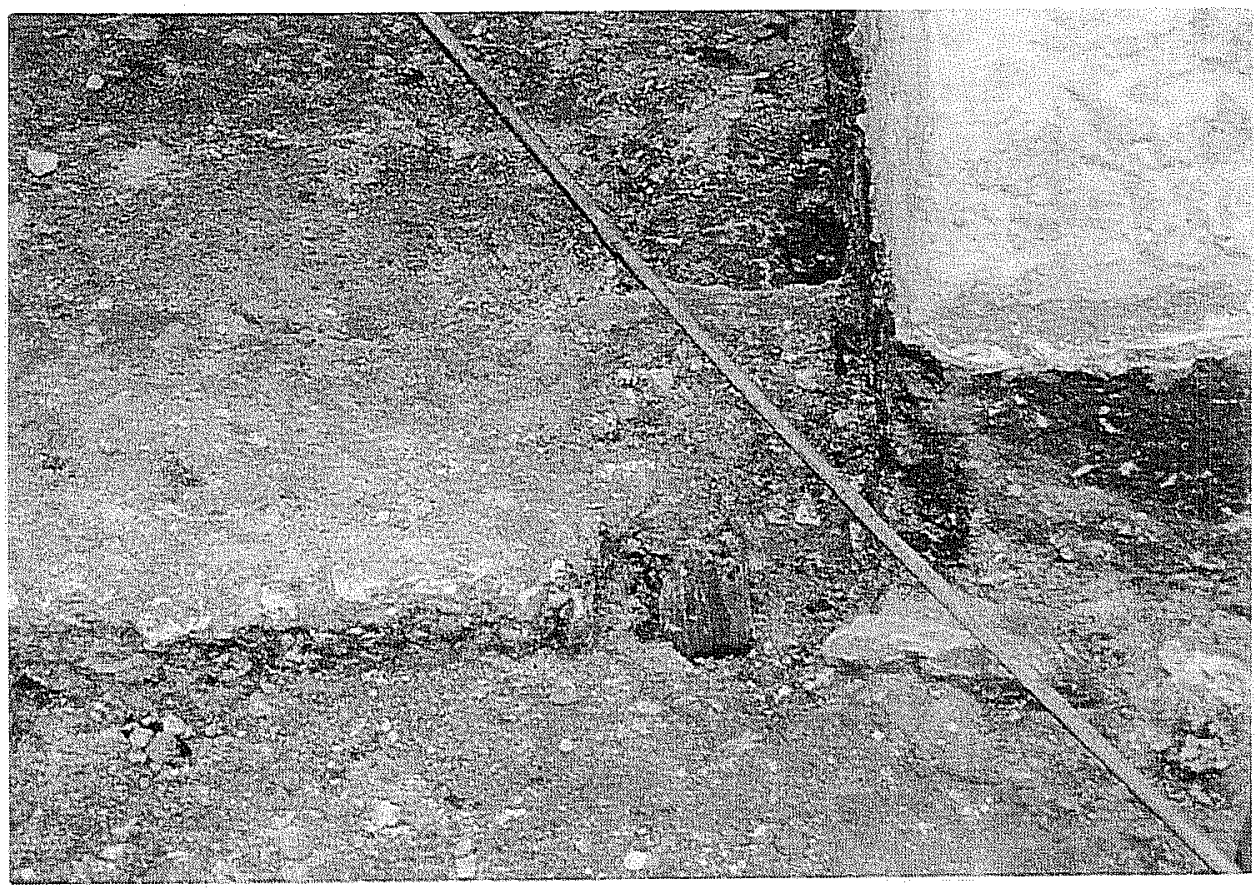

Figure 28. Cedar post set into foundation at southeast corner of the south transept, looking north. sediments, the caliche

surface was found to extend across most of Area A. Along the west wall of the excavation, near the police station foundation, was a disturbed area containing numerous decaying roots. These were identified by Bill Miller, Alamo horticulturalist, as palm tree roots. Photographs from the 1930s in the collection of the DRT Library show a palm tree in that spot.

Numerous sherds of handpainted lead-glazed ceramics were found just above the level of the Alamo foundation within Area A. Otherwise, the fill in Area A contained very few artifacts. Only one sherd from a burnished Tonala ceramic bowl, probably from the Spanish period, and two cut nails were recovered. The foundation of the west wall of the south transept was encountered $60 \mathrm{~cm}$ bgs and excavations ceased.

\section{Area B}

At the east end of the south transept, in Area B, another foundation was uncovered (Figure 30). This foundation was made of carefully finished concrete, measuring $46 \mathrm{~cm}$ wide by $46 \mathrm{~cm}$ deep, and had been fitted against the stones of the southernmost edge of the east wall of the south transept. A groove, $10 \mathrm{~cm}$ deep, was chipped in the concrete to allow for the placement of a cast-iron pipe which was part of a sprinkler system.

A 1-x-1-m test unit was placed in Area B inside of this foundation (see Figure 17). The unit was hand-dug in 10-cm levels and the sediment screened. The deposit was very similar to those south of the concrete foundation. The few artifacts recovered included both cut and wire nails. A 1-inch PVC conduit for the electric lines powering the lights outside the building was uncovered at about $12 \mathrm{~cm}$ bgs.

Between 32-35 cm bgs, the top of a brick pavement was discovered (Figure 31). The pavement was one brick thick and, with the exception of four yellow bricks in the middle, was made of red brick. Many of the latter had the logo "D'Hanis" pressed into them, but did not bear a Common Brick Manufacturers Association (CBMA) logo, suggesting a manufacture date sometime between 1908 and 1920 (see Chapter Six). 


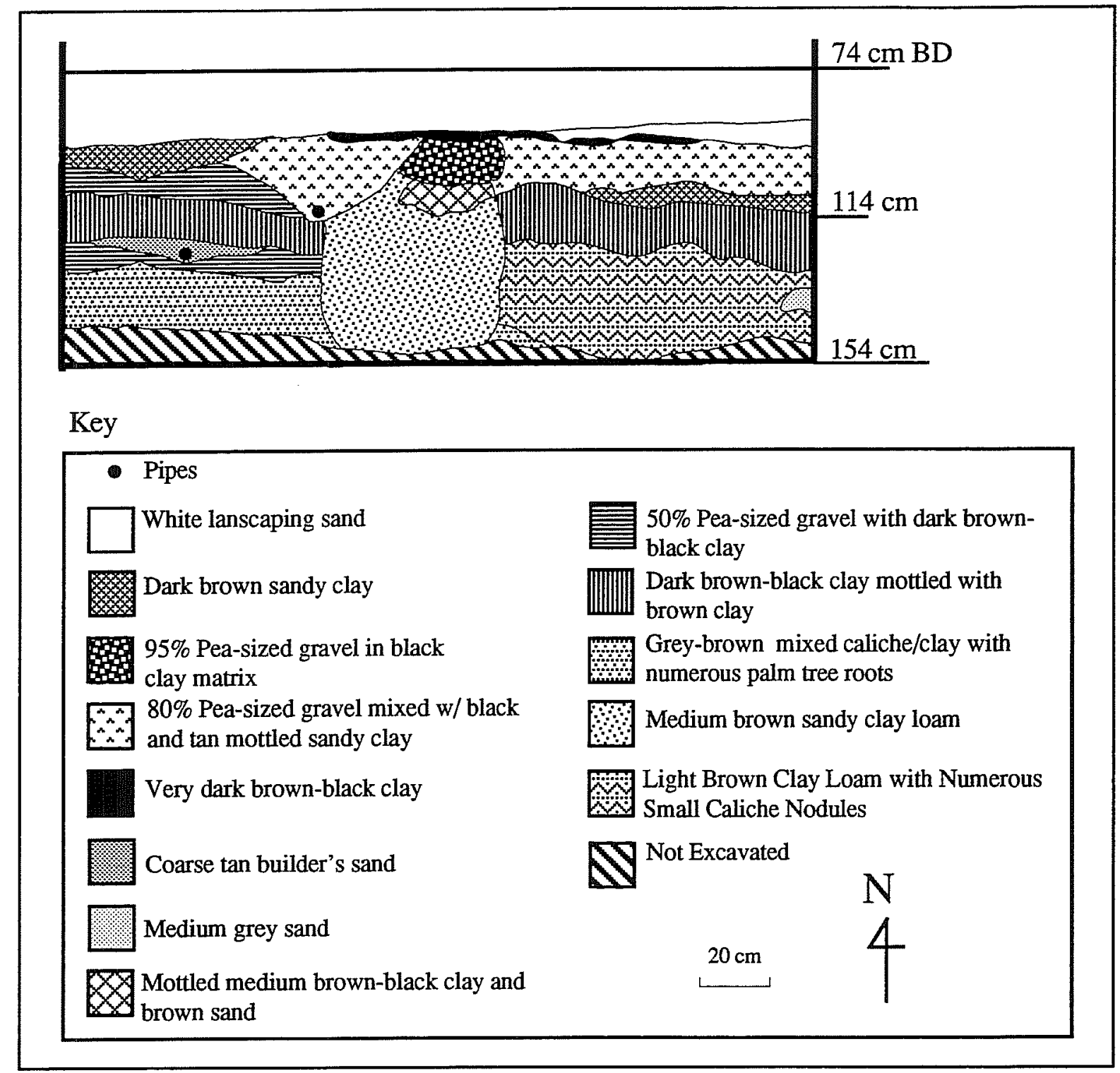

Figure 29. Profile of north wall of Area $A$.

The bricks had been laid adjacent to the north side of the concrete foundation, $5 \mathrm{~cm}$ below the top of the concrete. The brick paving measured $114 \mathrm{~cm}$ north/south and extended into the unexcavated area to the east. The western edge of the pavement began 107 $\mathrm{cm}$ east of the south transept wall.

The remaining fill in Area B above the level of the brick was removed by shovel by the construction crew. A small test unit was hand excavated to the west of the brick paving, to determine its depth and to examine the deposits below the brick. The dirt was a fairly friable, silty clay with less than 10 percent pea- sized gravels, and appeared to be fill. After handdigging and screening $20 \mathrm{~cm}$ below the brick (ca. $53-55 \mathrm{~cm} \mathrm{bgs}$ ), and finding the sediments virtually sterile, excavators switched to shovels and removed the remaining matrix west of the brick to a level of about $55 \mathrm{~cm}$ bgs keeping a watch for artifacts and screening every third bucketful. At $55 \mathrm{~cm}$ a sediment change was encountered and shoveling stopped. The new layer was a very wet, unconsolidated, mixed caliche and clay. A footing trench for the concrete foundation was cut into this layer. The rest of the area west of the brick was hand excavated to $65 \mathrm{~cm}$ bgs (Figure 32). Only a few artifacts were uncovered. 


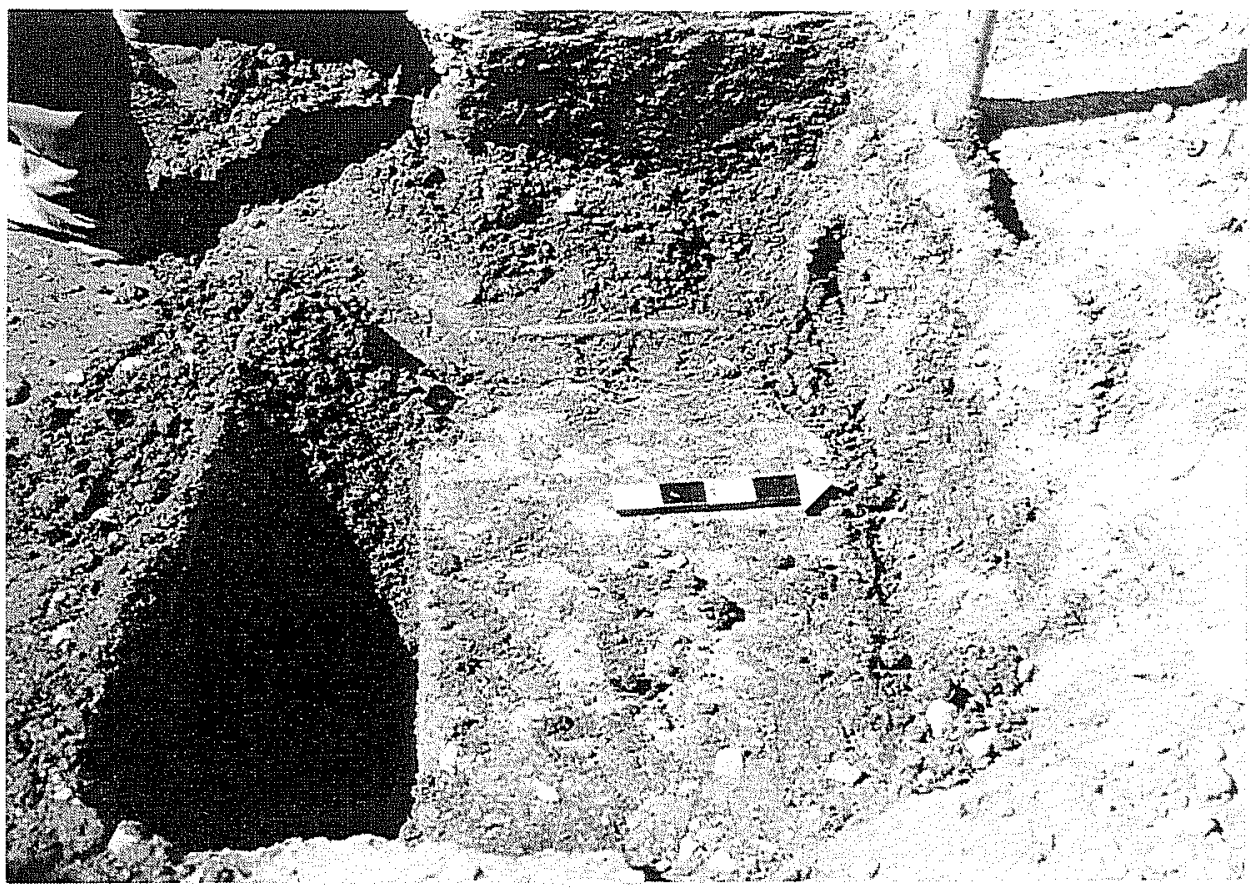

Figure 30. Concrete foundation at the easterm corner of the south transept, Area $B$, during excavation. Note the cast iron sprinkler pipe near the Alamo wall.

All datable artifacts were from the nineteenth century, mostly from the early part.

As the top of the Alamo wall foundation had not been uncovered within the upper $65 \mathrm{~cm}$ excavated thus far in Area B, a 10-x-20-cm test unit was dug adjacent to the wall to a depth of $80 \mathrm{~cm}$ below the surface. No definite foundation ledge was found, although loose limestone rubble was encountered. It appears that the east wall of the south transept was flush with the edge of the foundation.

The brick pavement was recorded and removed jiius to the beginning of the wall-cutting operation. The pavement extended only one more brick in width to the east. The purpose of this pavement is not known, though it may have been a "splash-guard" under the canales that drain the roof. The matrix beneath the pavement was removed by the construction crew with CAR personnel monitoring the work. The sediment, a friable sandy clay, was identical to that in Area B below the level of the brick pavement. No artifacts were observed.
Figure 31. Brick pavement in Area B, looking south. Note the concrete foundation at the top of the picture.

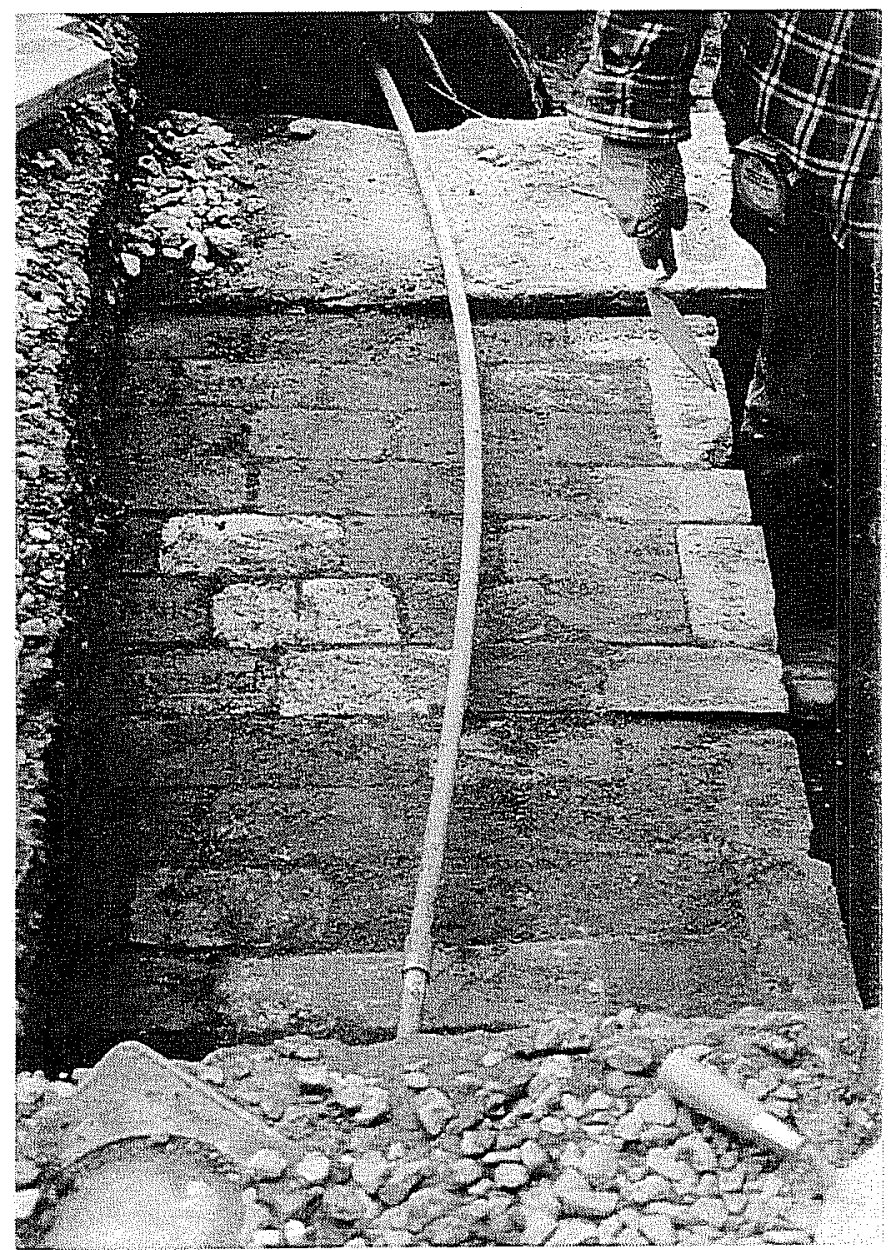




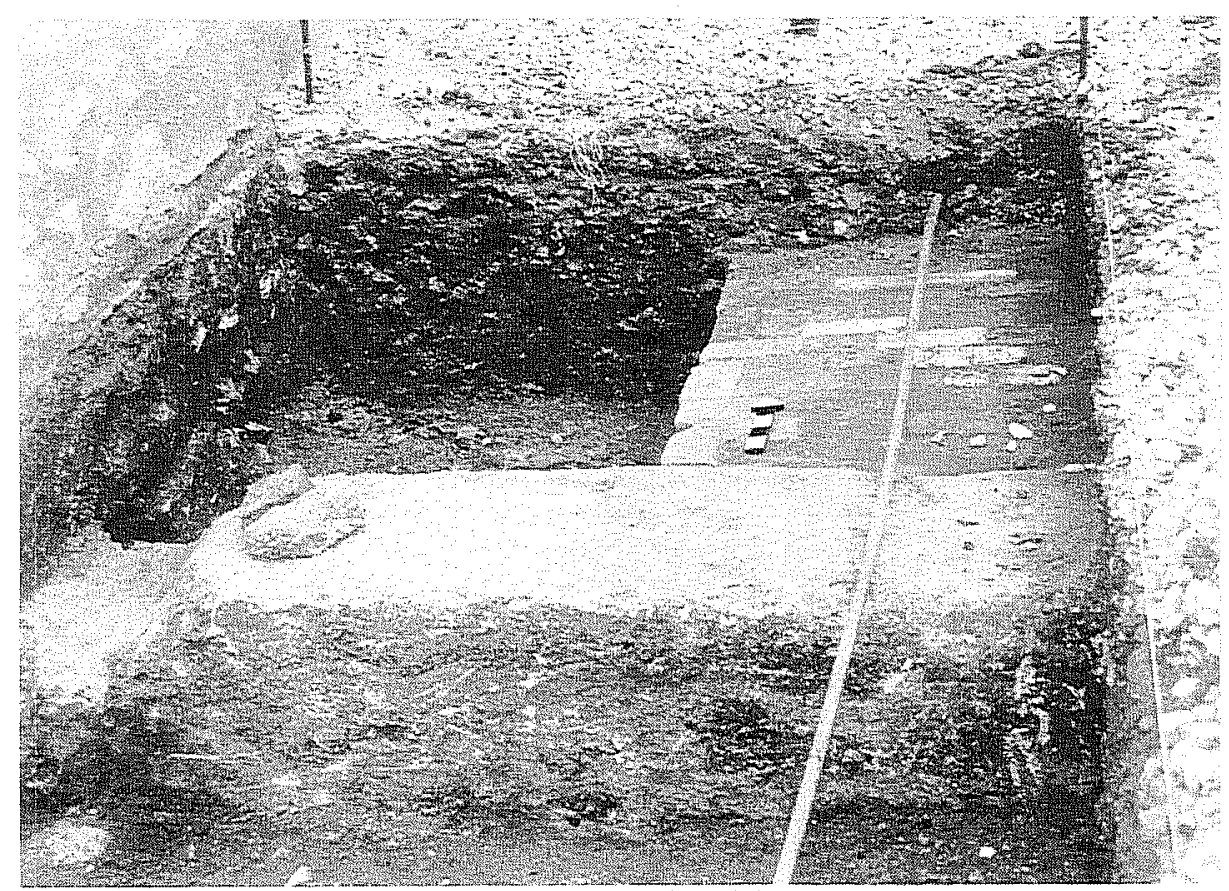

Figure 32. Area B, looking north, showing concrete foundation and brick pavement. Note the portion of concrete foundation removed for the sprinkler, next to the Alamo wall, on the left.

\section{Area C}

Area $\mathrm{C}$ contained a thin scatter of artifacts, largely of latenineteenth- and early twentiethcentury origin, which for the most part reflected domestic trash, including ceramics, glass bottle fragments, and butchered animal bone. Near the west corner of the south transept, a large number of handpainted, lead-glazed ceramic sherds were uncovered by workers. These were the same as the sherds found inside the police station foundation, in Area A.

Numerous pipes were monitored sediment removal (Figure 33). These have been identified as the cast iron pipes for a sprinkler system probably installed in 1937 and PVC pipes from a

Figure 33. Schematic diagram of exterior excavations

showing all encountered pipes.

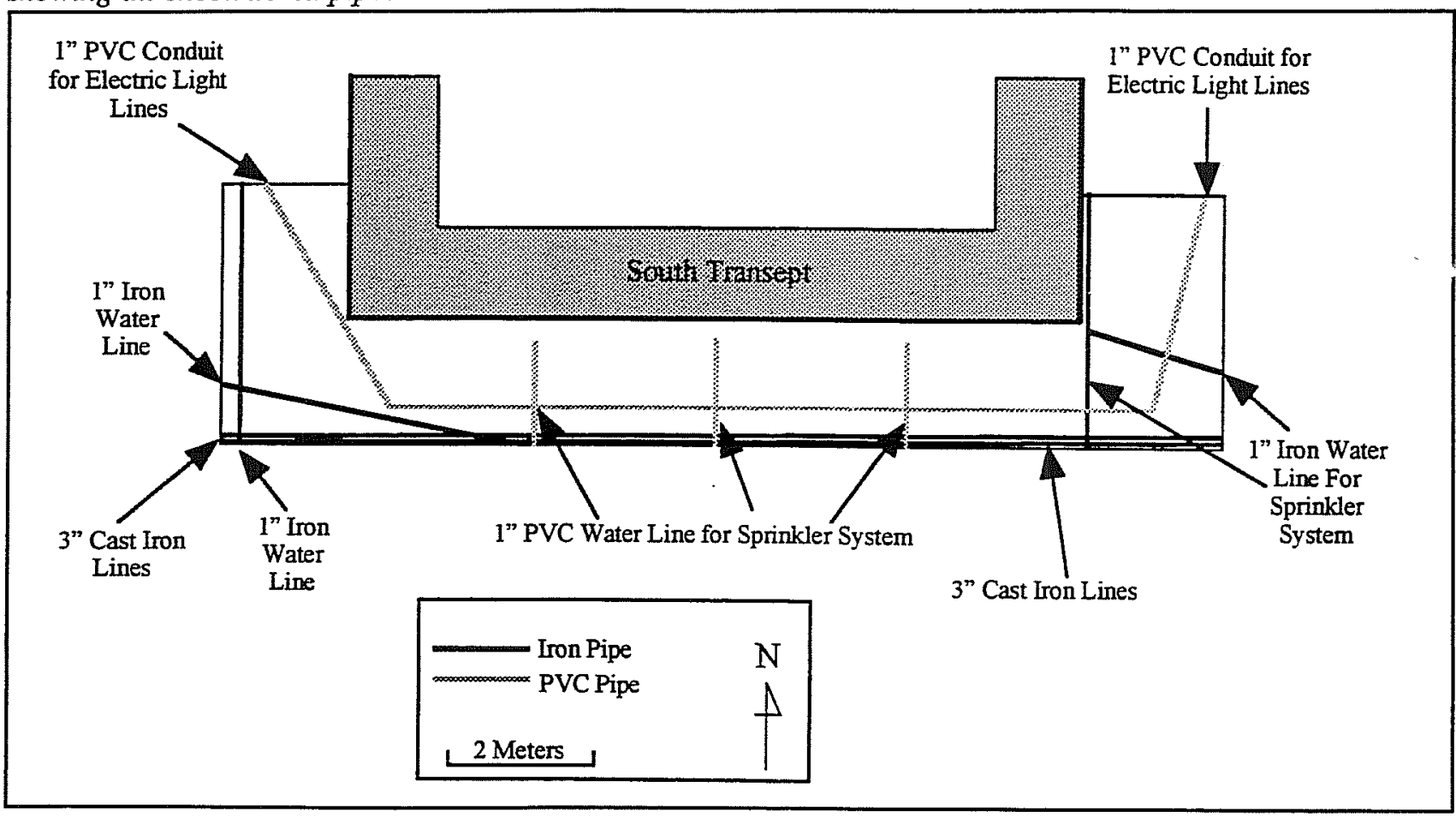


more recent sprinkler system. The lights set into the ground at intervals around the walls of the church were powered by electric lines also incased in PVC conduit.

When the workers finished removing sediment from Area C, CAR personnel cleared the remainder of the sediment down to either the top of the caliche surface (Figure 34), or to about $3 \mathrm{~cm}$ below the top of the lowest stone in the foundation, which ever came first (Figure 35). During the clearing operations, two U.S. pennies, dated 1969 and 1976, were found lying directly on the surface of the foundation, about $1.5 \mathrm{~m}$ east of the western edge of the south transept.

All Alamo foundation stones were measured, drawn (Figure 36), and photographed (Figures 37, 38, and 39). The foundation stones were found to be very roughly dressed and uneven. The elevation of the top surface of the foundation varies from $124.0 \mathrm{~cm}$ below datum to $137.5 \mathrm{~cm}$ below datum (Figure 40).

The caliche surface extended only part way into the eastern portion of Area $C$ (compare the caliche

Figure 35. Caliche surface at west end of Area $C$, looking east. Note pipe trench on right and police station foundation with cedar post on left.

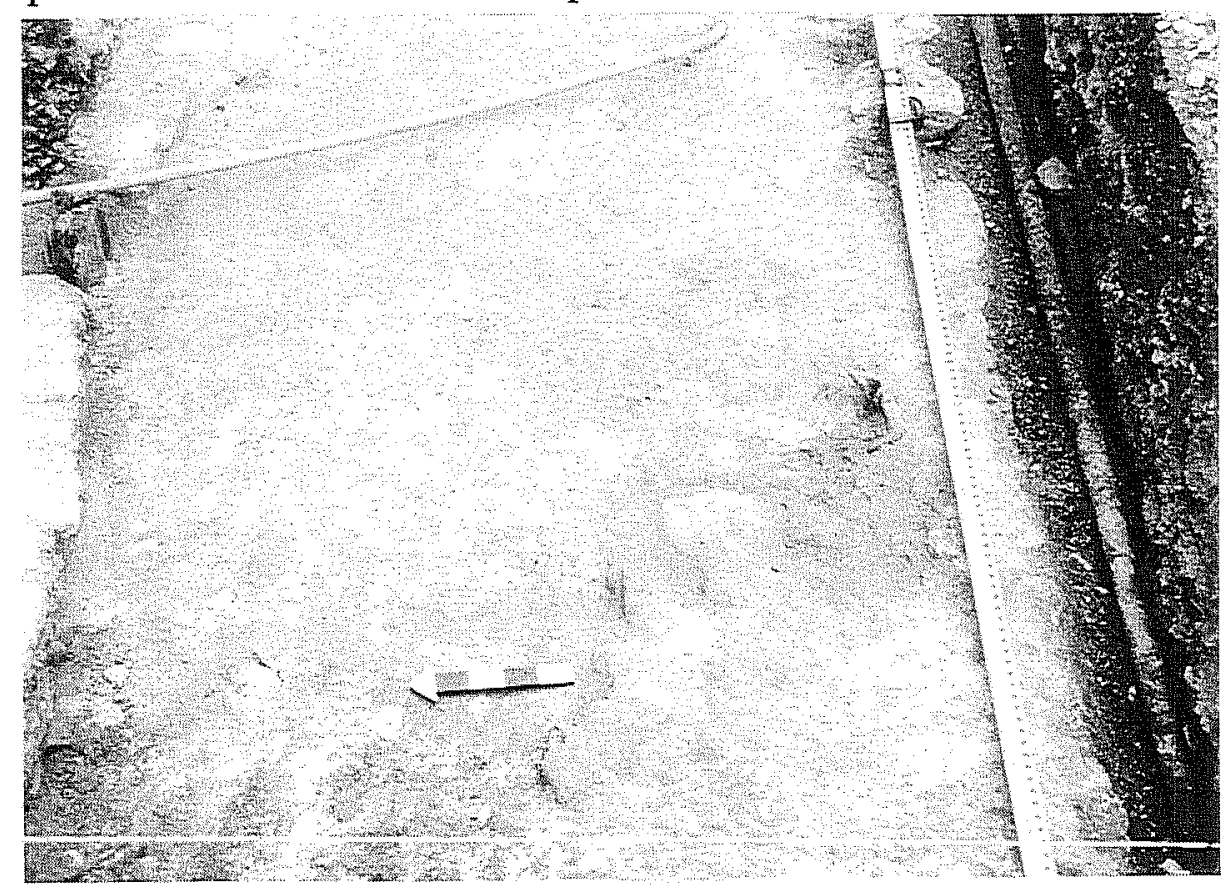

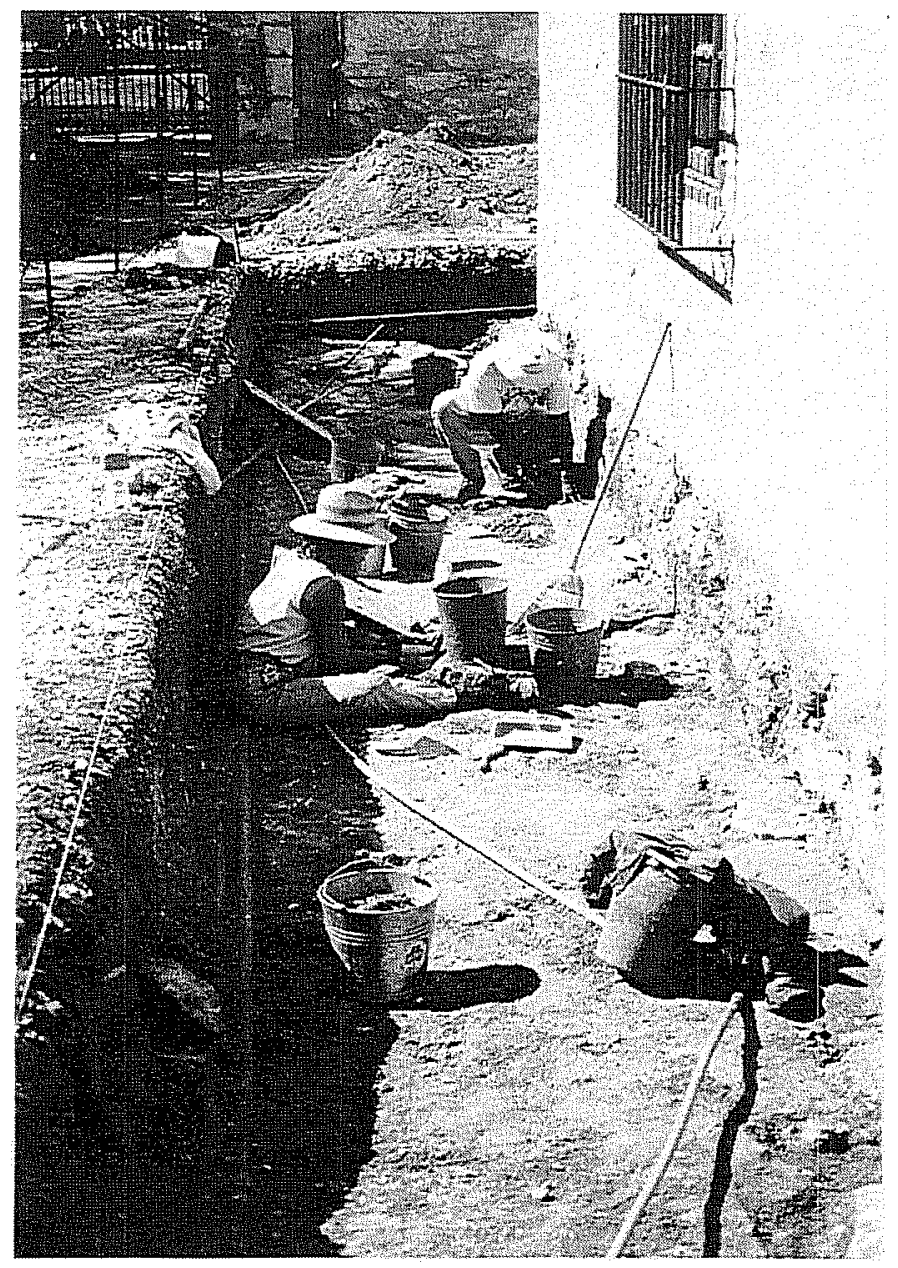

Figure 34. CAR personnel clearing bottom of exterior excavation, looking west. Note the numerous pipes.

surface in Figures 37, 38, and 39). Small portions of this surface were found in scattered places further east, especially along the foundation stones and the pipe trench which cut through the southern edge of the excavation. Other areas lacked this caliche layer and appeared disturbed at the level the excavations stopped. Figure 41 is a map of the exterior excavations, including notes of which figures detail the profiles. 

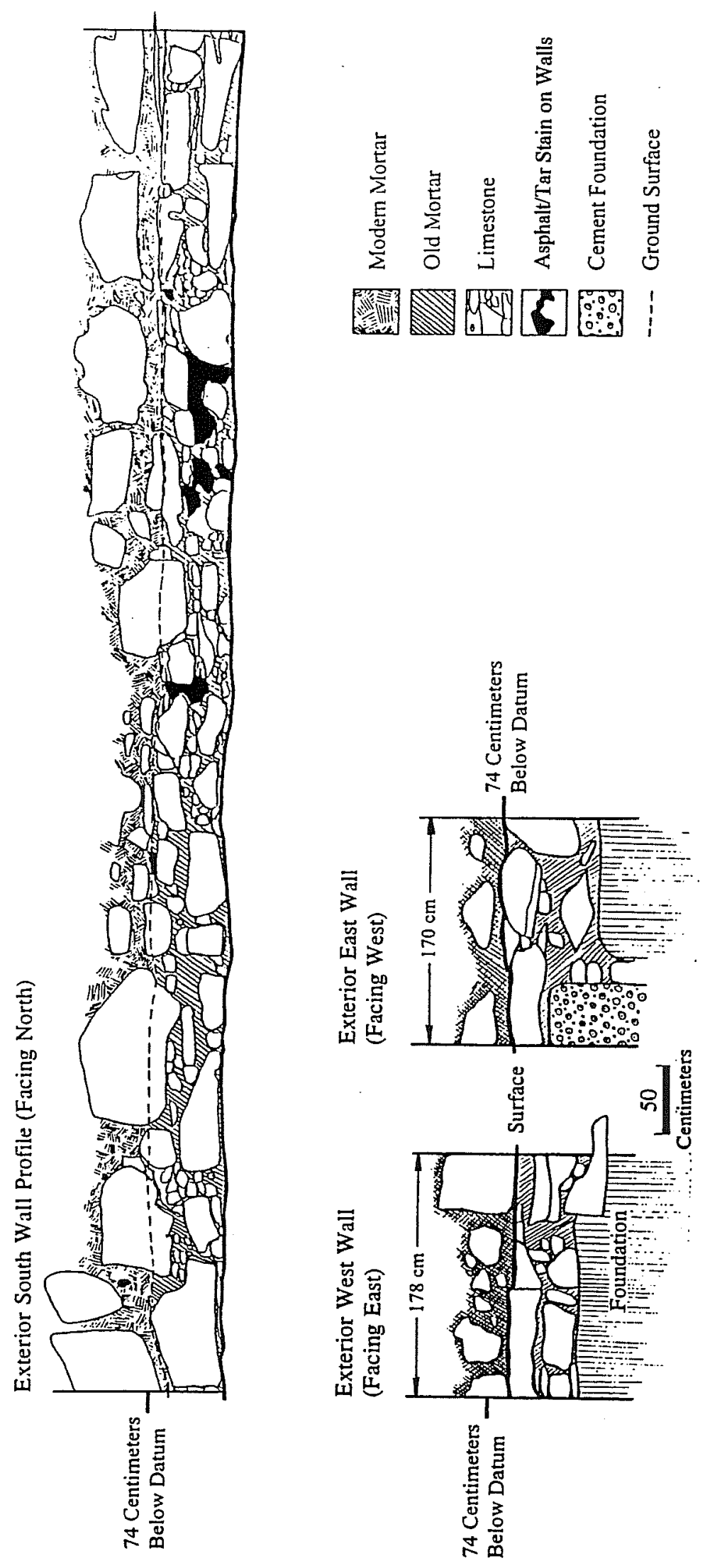

| 


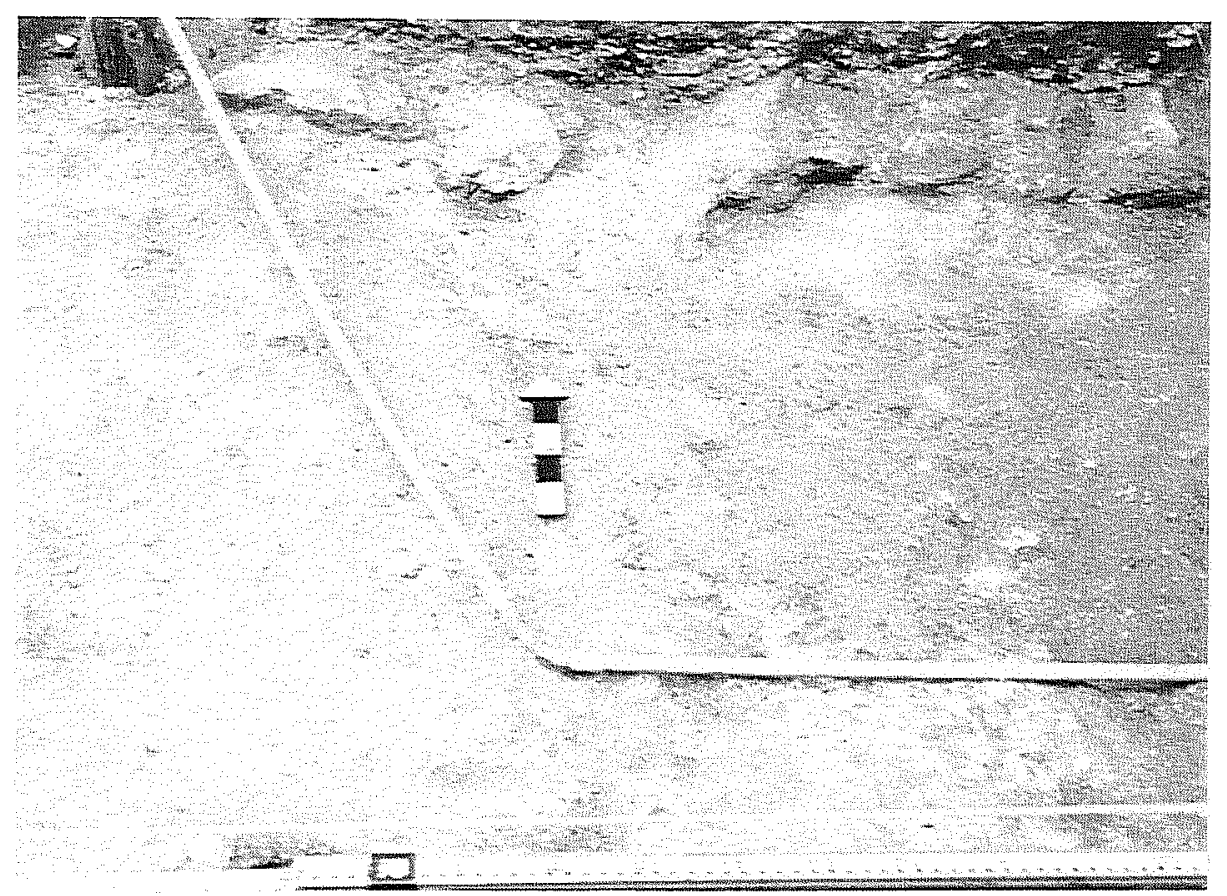

Figure 37. Caliche surface and Alamo foundation stones at the west corner of the south transept. The cedar post associated with the police foundation is visible in the upper left corner.

Figure 38. Alamo foundation stones at the center of the south transept.

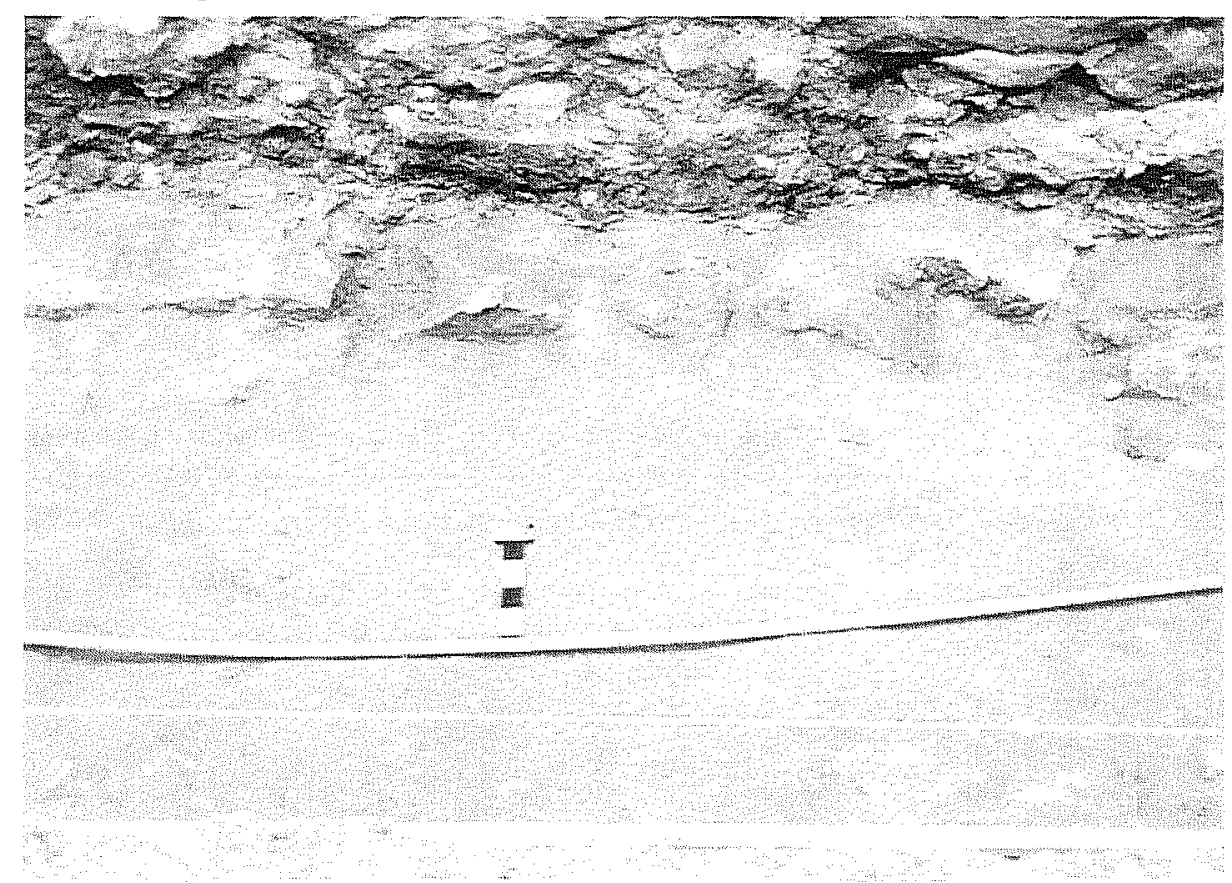




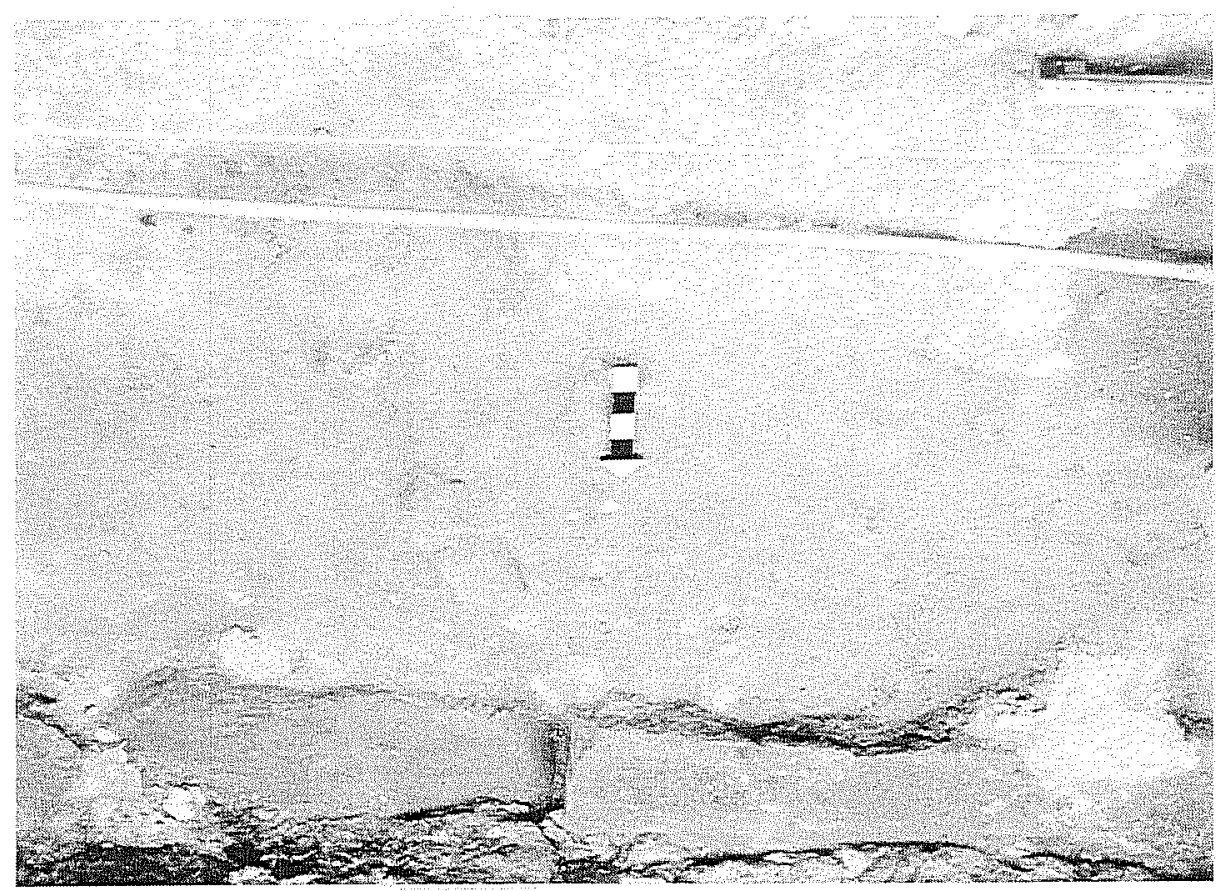

Figure 39. Alamo foundation near the eastern edge of the south transept. Note the patches of caliche surface at bottom.

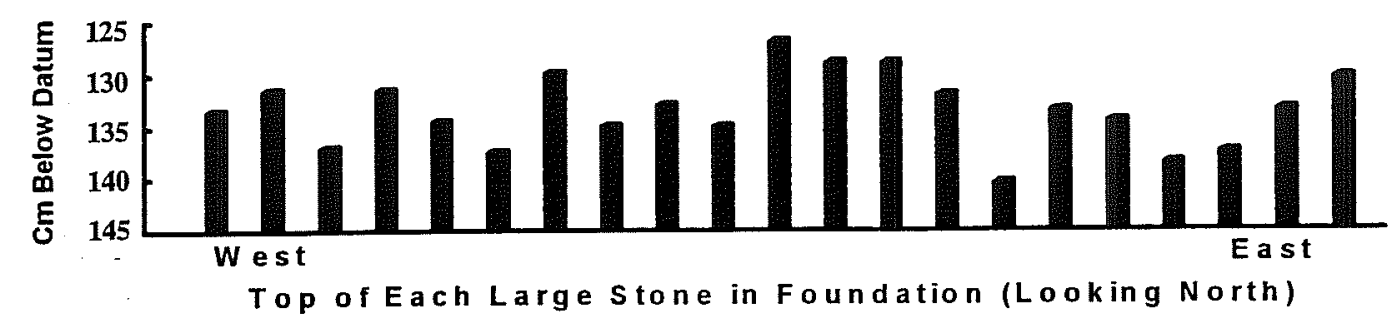

Figure 40. Diagram of uneven foundation stone elevations, taken 21 locations along south wall. 


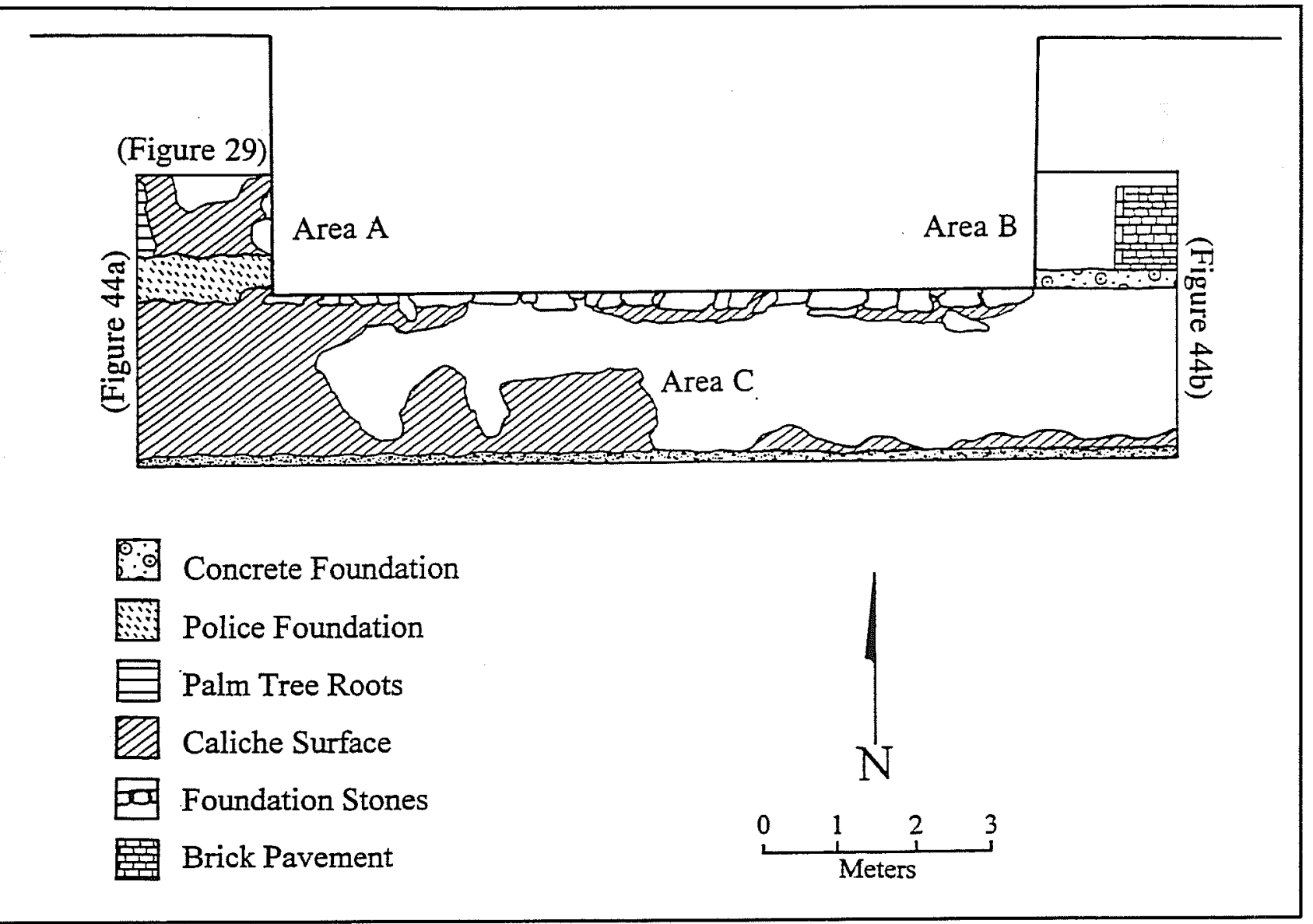

Figure 41. Plan view drawing of complete exterior excavations. Profiles included in this report are noted.

\section{Later Monitored Excavations}

In May 1995, the removal of the concrete foundation in Area B was monitored by CAR personnel. The foundation was exposed by shovel, then cut into sections about $40-50 \mathrm{~cm}$ thick with a power saw and removed (Figure 42). The cut sections revealed that there was no reenforcement bar in the foundation, and that a large percentage of the volume was taken up by chunks of limestone rubble averaging about $20 \mathrm{~cm}$ across the longest dimension, with some as large as $40 \mathrm{~cm}$ across. This foundation had cracked at some time in the past, at a point two meters from the Alamo wall. At a point $4.65 \mathrm{~m}$ from the Alamo wall, roughly parallel to the back wall of the church, someone had chopped the concrete out to accommodate placement of five pipes. Two 2-inch cast iron pipes, placed just east of and parallel to the east wall of the church, were uncovered at $20 \mathrm{~cm}$ below the surface of the concrete. The remains of the concrete foundation appeared to terminate directly beneath these pipes. The other pipes were two 1-inch PVC lines which were lying next to each other about $10 \mathrm{~cm}$ above the two iron pipes, and a 1-inch copper pipe lined with rubber insulation next to the two PVC pipes. Groundskeeper Bill Miller informed us that this was a drain line from the air conditioners in the Shrine. The concrete foundation did not continue past the pipes.

The purpose of the foundation was at first unknown. It could not have been the foundation of the building shown attached to the south transept in the 1877 Sanborn map (see Figure 10), as it extended beyond the end of the back wall of the Alamo. Fortunately, in June 1995, the DRT library purchased a set of photographs taken of the Alamo before the construction of the museum north of the church. One of these photographs (Figure 43) shows a low stone wall beginning at the southeast corner of the transept 
extending east to approximately the western edge of the restored acequia, turning north and continuing on across the back of the building. Internal evidence in the photograph suggests that it was taken between about 1931 and 1936, probably in the later part of the period. The wall and eastern part of the foundation would have been removed in 1937 when the acequia restoration took place, at which time the easternmost section of the concrete foundation was also removed. The construction date is unknown, though it cannot have been before April 1917, as the report of the custodian of the Alamo for that year notes,

now we still have the back or east wall of the building and fig tree not enclosed. We have not ventured to fence there, for it will take such a strong fence to hold our own, and will cost at least $\$ 25$, but it should be done . . . [Report of the Custodian of the Alamo, April 18,1917 , on file at the DRT Library].

It is important to note that the top of the concrete foundation in Figure 43 is above the ground surface. Although the stone piled along the south wall of the building makes it difficult to estimate, the ground surface at the time appears to have been $40-50 \mathrm{~cm}$ lower than the modern surface.

In June 1995, additional excavations, monitored by $\mathrm{CAR}$, took place along the east wall of the south transept and the south wall of the apse, extending to the back wall of the Alamo. The purpose of these excavations was to place a moisture barrier against the walls. The excavations were about $60 \mathrm{~cm}$ wide and $60 \mathrm{~cm}$ deep. The excavated sediment contained a few pieces of rusted metal, a few undecorated whiteware ceramics, and an occasional wire nail which were not collected. Only a Pontiac hubcap, a fragment of a Champion spark plug, a fragment of a ceramic pipe, and a piece of decal-decorated porcelain were collected. These are described in Chapter Six.

During these excavations, a five-inch ceramic sewer pipe was found running parallel to the south wall of

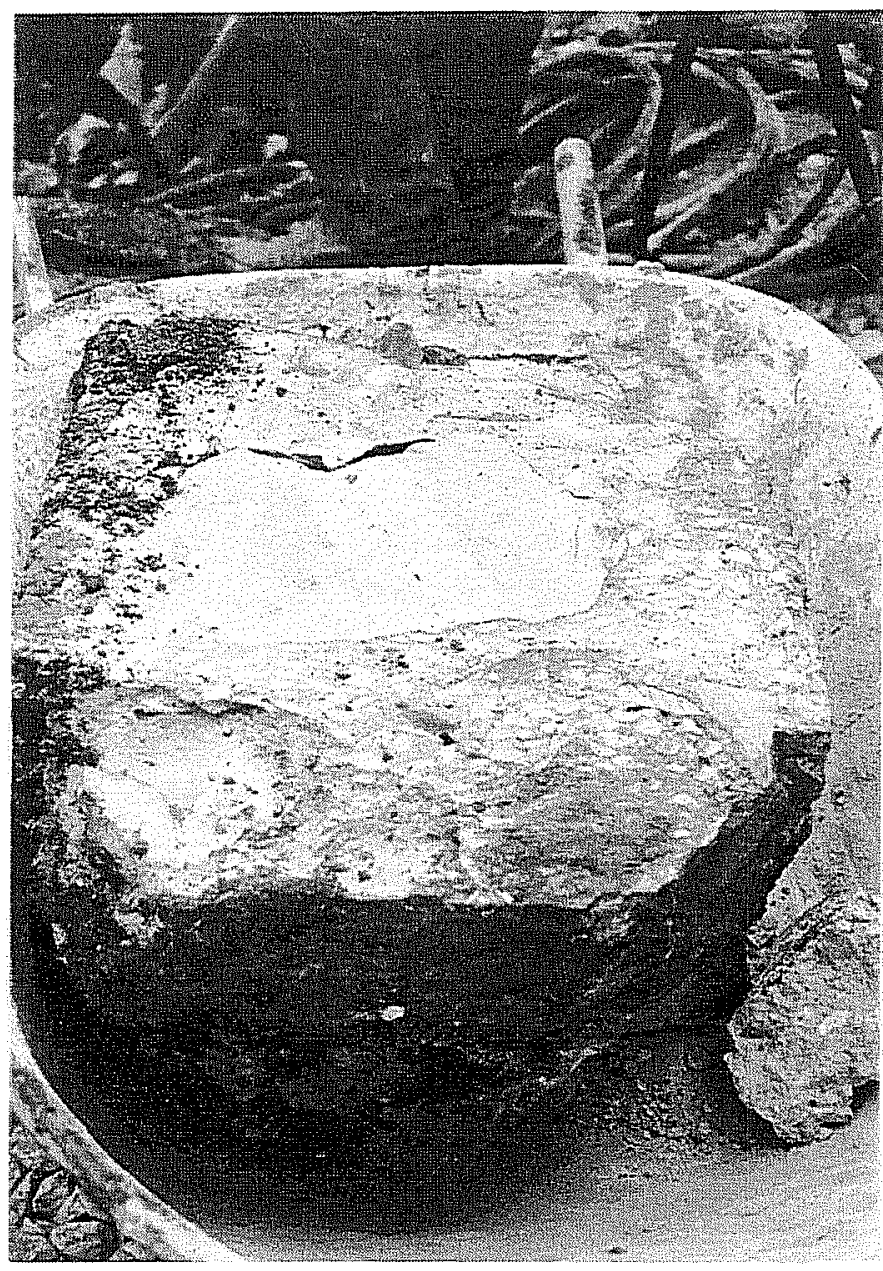

Figure 42. Portion of concrete foundation in a wheelbarrow, during removal, showing cut face. The foundation was $46 \mathrm{~cm}$ across. Note the large chunks of limestone.

the apse at a depth of $65 \mathrm{~cm}$ bgs. CAR archaeologists dug a small test pit next to the wall near the southeast corner of the Alamo (see Figure 20). At $85 \mathrm{~cm}$ below the surface, the caliche surface was encountered. For some $10 \mathrm{~cm}$ above this, the matrix was grey-brown clay, mixed with caliche, as was seen in the lowest level of Area B. In this clay-caliche mix, several glass bottle fragments were uncovered. Diagnostic glass pieces were all free-blown, indicating a date before the middle of the nineteenth century (see Chapter Six). A second hand-dug pit was placed at the corner of the transept and the apse (see Figure 20). Several pieces of broken ceramic sewer pipe were found 60 $\mathrm{cm}$ bgs. Limestone rubble, similar to that found in the test pit dug near the concrete in Area B, was found in this corner. Beneath this was the clay-caliche deposit, 


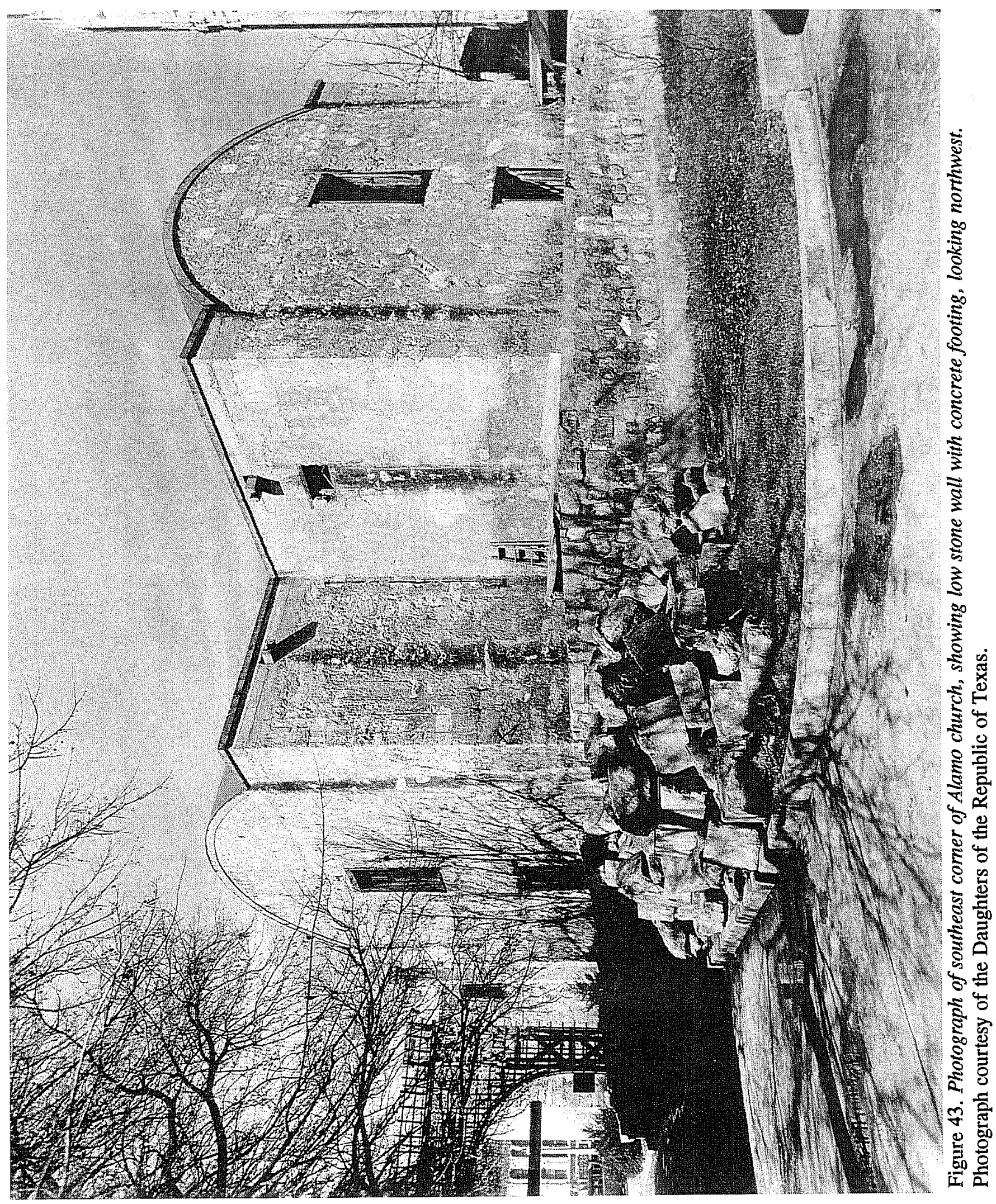


containing several bottle fragments. Again, the diagnostic pieces had all been free-blown. The packed caliche layer was found $92 \mathrm{~cm}$ bgs. Note that the ground surface of this area is not even, which accounts for most of the differences in depth of the caliche surface.

\section{Discussion}

Information obtained from the exterior excavations and photographs made it clear that, with one exception, virtually every square centimeter of the dirt removed during the project had been disturbed and, in at least one area, as recently as 1976 . The extent of this disturbance is illustrated in the profiles of the east and west walls of the excavation, as shown in Figure 44.

The datable artifacts recovered from the exterior excavation (see Chapter Six) represent every period during the existence of the building. The majority appeared to be of late-nineteenth- or early twentiethcentury origin. Only a single piece of modern plastic
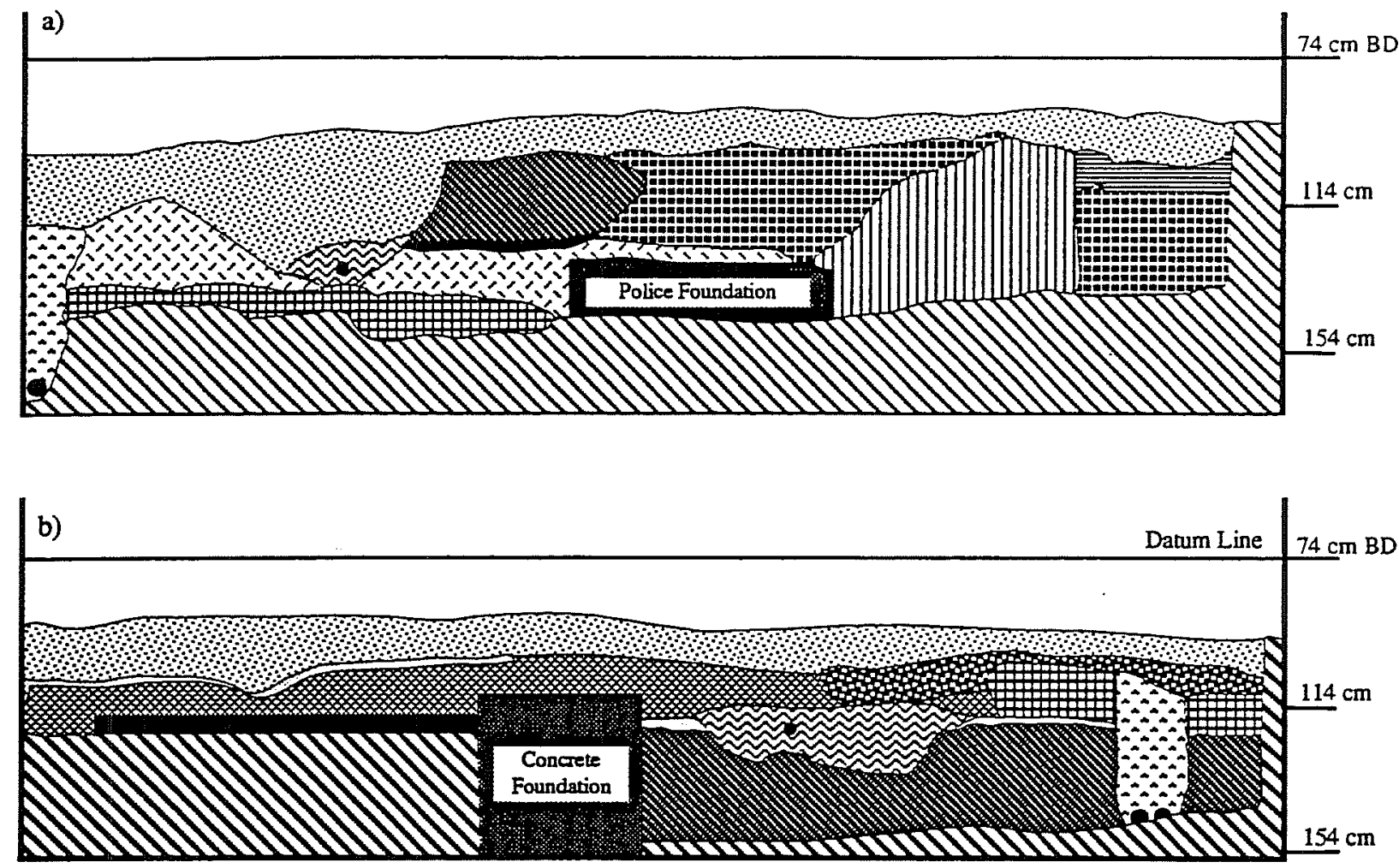

KEY

\begin{tabular}{|c|c|c|}
\hline $\begin{array}{l}\text { Brick Floor } \\
\text { - Metal Pipes }\end{array}$ & $\begin{array}{l}\text { Medium Brown Very Sandy } \\
\text { Clay }\end{array}$ & Medium Gray-Brown Silty Clay \\
\hline $\begin{array}{l}\text { Brown Sandy Clay w/ Small Caliche } \\
\text { Nodules \& 20\% Pea-sized Gravel }\end{array}$ & 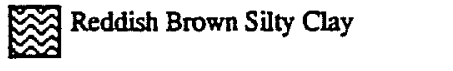 & $\begin{array}{l}\text { Med Grey Sandy Clay. w/ Numerous } \\
\text { Decomposed Palm Roots }\end{array}$ \\
\hline Caliche & $\begin{array}{l}\text { Eight Brown Silty Clay w/ 10-20\% } \\
\text { Pea-sized Gravels }\end{array}$ & Medium Grey Very Sandy Clay \\
\hline $\begin{array}{l}90 \% \text { Pea-sized Gravel in Black } \\
\text { Clay Marrix }\end{array}$ & $\begin{array}{l}\text { Very Dark Brown Dense Clay } \\
\text { w/5-10\% Pea-sized Gravels }\end{array}$ & $\begin{array}{l}\text { Reddish Brown Sandy Clay w/ } \\
\text { Caliche Nodules }\end{array}$ \\
\hline Dark Brown Sandy Clay & 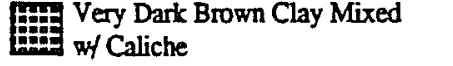 & Not Excavated \\
\hline
\end{tabular}

Figure 44. Profile of the east and west walls of the completed exterior excavation. a. west wall, b. east wall. 
and one pop-top tab, diagnostic of the second half of the twentieth century, were recovered. The DRT's careful maintenance of the property has resulted in very little trash remaining on the grounds outside the chapel since 1905 .

Information in Figure 43 suggests that the sediments above the level of the concrete foundation were probably placed there about 1937 , when the concrete acequia was constructed over the remains of the original, just east of the church building. The concrete of the acequia was set higher than the stones of the original, and the fill would have been necessary to level the ground surface between the wall of the Alamo and the reconstructed acequia. Examination of Figure $44 \mathrm{~b}$ shows evidence of this fill, though it has been disturbed several times since it's deposit.

Micromorphological examination of this sediment also indicates that it had been dumped there rather than accumulating by natural depositional processes (see Appendix A). This micromorphological report also suggests that the fill had been subjected to considerable heat. The presence of mostly household garbage in the exterior excavations may suggest that this fill was removed from some area near a dwelling, and placed as a secondary fill deposit at the Alamo, though some of or all of it may have in fact come from the police station. Later, during the multiple excavations of the area for pipe-laying and landscaping, these artifacts were thoroughly mixed with those already present. In small places (such as the area under the brick pavement), the older, pre1937 strata may not have been seriously disturbed by subsequent digging. The low frequency of Colonialperiod artifacts in all areas indicates that strata containing Colonial deposits may not have been significantly disturbed and mixed with more recent deposits. It is likely that the Colonial deposits lie within and below the level of the caliche layer. These caliche layers encountered in previous excavations usually contained Colonial period artifacts, or covered other strata that contained such artifacts (Eaton 1980; Greer 1967; Schuetz 1973; Sorrow 1972). Therefore, even though the area around the south transept has been seriously disturbed, with considerable mixing of
post-Colonial strata, it is likely that some Colonial period strata remain undisturbed below the level of the 1995 CAR excavations.

The only exception to the generally disturbed state of the exterior dirt is the $10 \mathrm{~cm}$ or so of grey caliche/ clay encountered east of the transept. This layer contained numerous examples of early nineteenthcentury artifacts, including some ceramics and several free-blown bottles. This level may represent an undisturbed nineteenth-century layer above the hardpacked caliche. How far this layer may extend around the exterior of the building is not known.

\section{Interior Excavations}

The sediments excavated in the interior units were found to consist of a dry, crumbling, dark brown, very sandy clay with large amounts of limestone rubble and smaller amounts of sandstone fragments (Figures 45 and 46). Almost all datable artifacts recovered from the interior were from the nineteenth century or earlier. The exceptions were a few wire nails and one 1933 U.S. penny recovered near the eastern wall of the alcove area. The mixture of dirt and limestone rubble had apparently been used as secondary fill. In places there were lenses of lighter brown sediments, which appear to be the same dry, sandy clay with varying amounts of caliche mixed into it (Figure 47). No other distinct changes in soil color or texture were noted. Large numbers of rodent bones were recovered, indicating that humans were not the only agents responsible for mixing sediments.

In several of the excavation units were numerous amorphous lumps of a tar and/or asphalt material, usually at or near the ground surface although some could be found throughout the excavated sediments (Figure 45), as deep as the bottom of the excavation (143 $\mathrm{cm}$ bd). Some of these chunks were as large as $40-50 \mathrm{~cm}$ in longest dimension. Tar stains from this material form a line across the interior wall of the transept at about the level of the floor of the alcove, although many chucks of this material were seen 


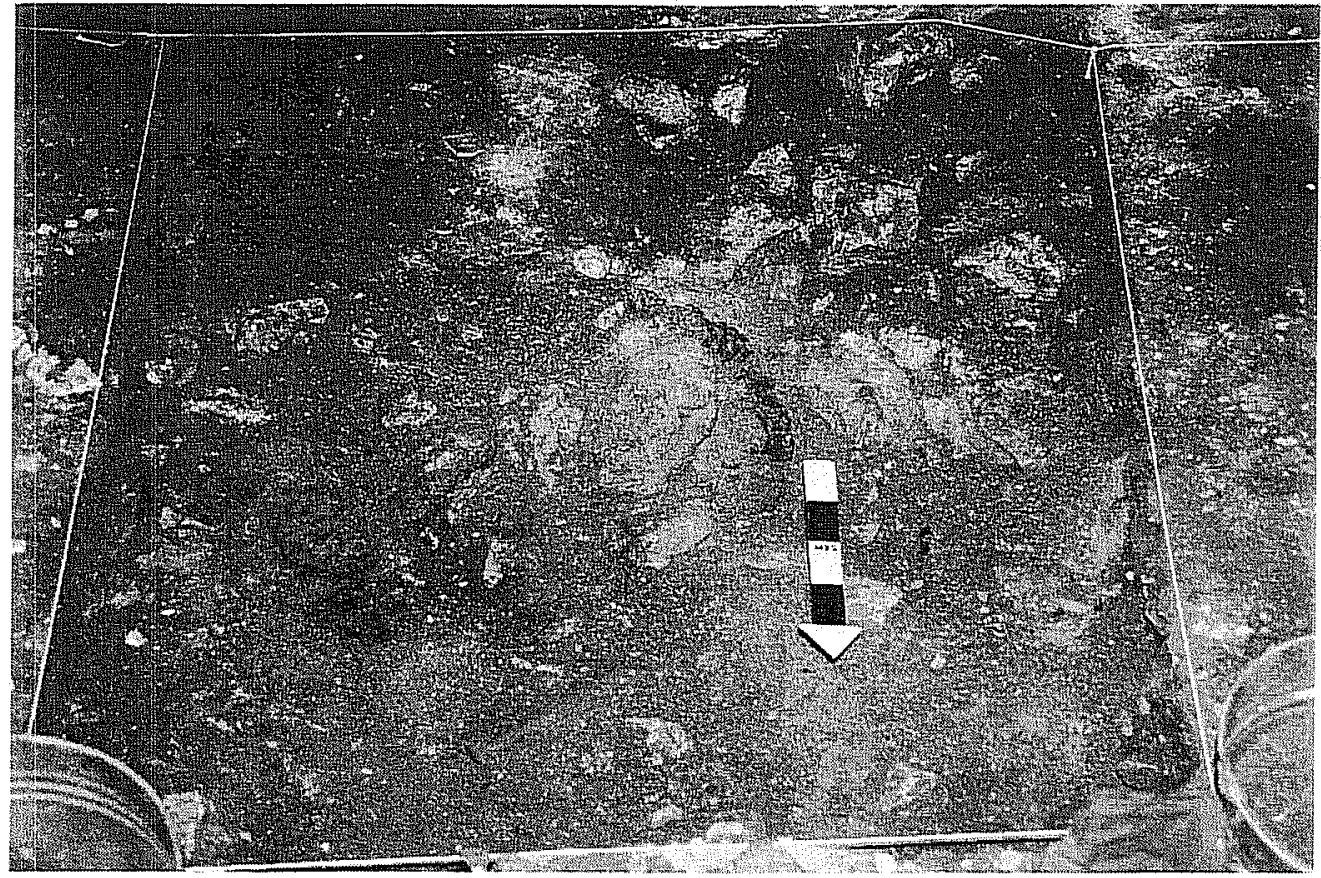

Figure 45. Excavation Unit 101N/98E at ca. $114 \mathrm{~cm}$ bgs.
The base of the alcove was uncovered at ca. $132 \mathrm{~cm}$ below datum, slightly above the elevation of the foundation. The stones in this area were much less uneven. This may be the threshold of the small door through the south wall of the south transept seen in many drawings and paintings of the Alamo church prior to the U.S. Army renovations (see Eaton 1980:50). However, one informant, writing in 1905 of his first view of the

higher and lower than this level. The material appears to have been laid directly on the ground surface and at one point may have served as the paving for a floor. In places where it covered limestone rocks, it appeared more like asphalt, but the ground surface around these rocks appeared to have been permeated with the tar/asphalt material to form a hard, rough surface, sometimes as much as $10 \mathrm{~cm}$ thick or more. This material was found in patches throughout the excavations, but was most common in the 93E units and in the 97-98E units.

Occasionally the asphalt was found as far as $40 \mathrm{~cm}$ bgs. Picks were used to remove this material from the units. In unit 100.5N/98E (in the alcove), a large piece of the asphalt material was on top of several pieces of limestone rubble. Along the edges of the asphalt, a .5- to $1-\mathrm{cm}$-thick layer of white crystals was observed. These are believed to be calcium carbonate or some other mineral salt which had accumulated under the asphalt (Figure 48). Although the asphalt/tar/dirt mixture may have once formed a floor, it has been heavily disturbed, with broken chunks of the material scattered through much the excavated sediment.
Alamo in 1845, insisted that artists' renderings like the Gentilz painting shown in Eaton (1980:50) were inaccurate: "he even arches the breach in the south wall of the church" (Everett 1975:18). While Gentilz's highly romanticized painting might be questioned, the sketches of Seth Eastman, an army captain who passed through San Antonio in 1848, are simple and accurate. Two of these sketches, in the possession of the McNay Art Institute, show the southern side of the Alamo, and both show a low door with an arch of cut stone (Burkhalter 1961:44-46).

This door was probably sealed when the two windows were added to the south wall of the transept. Local tradition states that this door was a puerta de los muertos, a "door of the dead" (Dorothy Black, personal communication 1995), that is, a door through which the body was removed after a funeral. However, no documentation discovered thus far explicitly mentions the door or its original purpose. During removal of the last level of sediments in all units, several areas, especially in front of the alcove, were found to have very soft deposits, which, when stepped on, visibly sank. These areas were avoided when identified. In these areas the lenses of sandy silt 


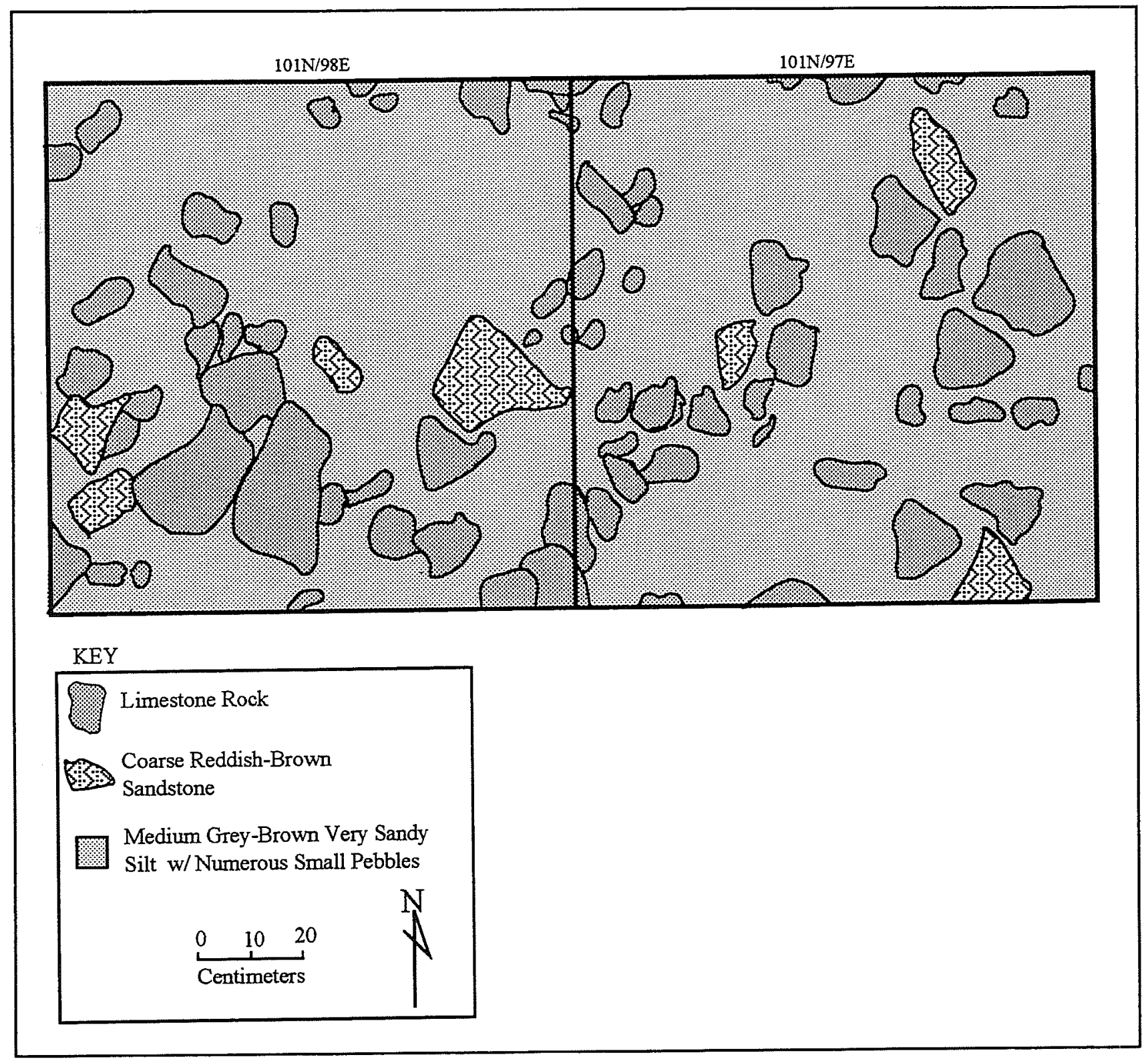

Figure 46. Plan drawing of Units 101N/97-98E, at ca. $124 \mathrm{~cm}$ bgs.

mixed with caliche had been seen in previous levels. These were the areas where most of the few Colonial period ceramics were found. During the final cleanup of the bottom of the excavation at $143 \mathrm{~cm}$ below datum, the agreed limit of the excavations, the bottom of the excavation in two small places (less than $20 \mathrm{~cm}$ wide) collapsed into cavities. These might be old rodent burrows, as a large number of rodent bones were recovered during the excavation (see Chapter Seven). When one of these collapsed places was carefully cleared out, a portion of a human maxilla was observed $20 \mathrm{~cm}$ below the level at which excavations stopped. Both cavities were backfilled. Later the same day, while CAR personnel were clearing the last of the asphalt/tar/dirt mixture from the bottom of a unit, the floor again collapsed, revealing another cavity. A long bone was observed at the bottom of the cavity, resting about $20 \mathrm{~cm}$ below the bottom excavated level. Although what little of this bone which could be seen appeared to be human, it was not touched or removed, and positive identification could not be made. As there was no need to extend the excavation further, and assuming that the bone was human, the cavity was backfilled. 


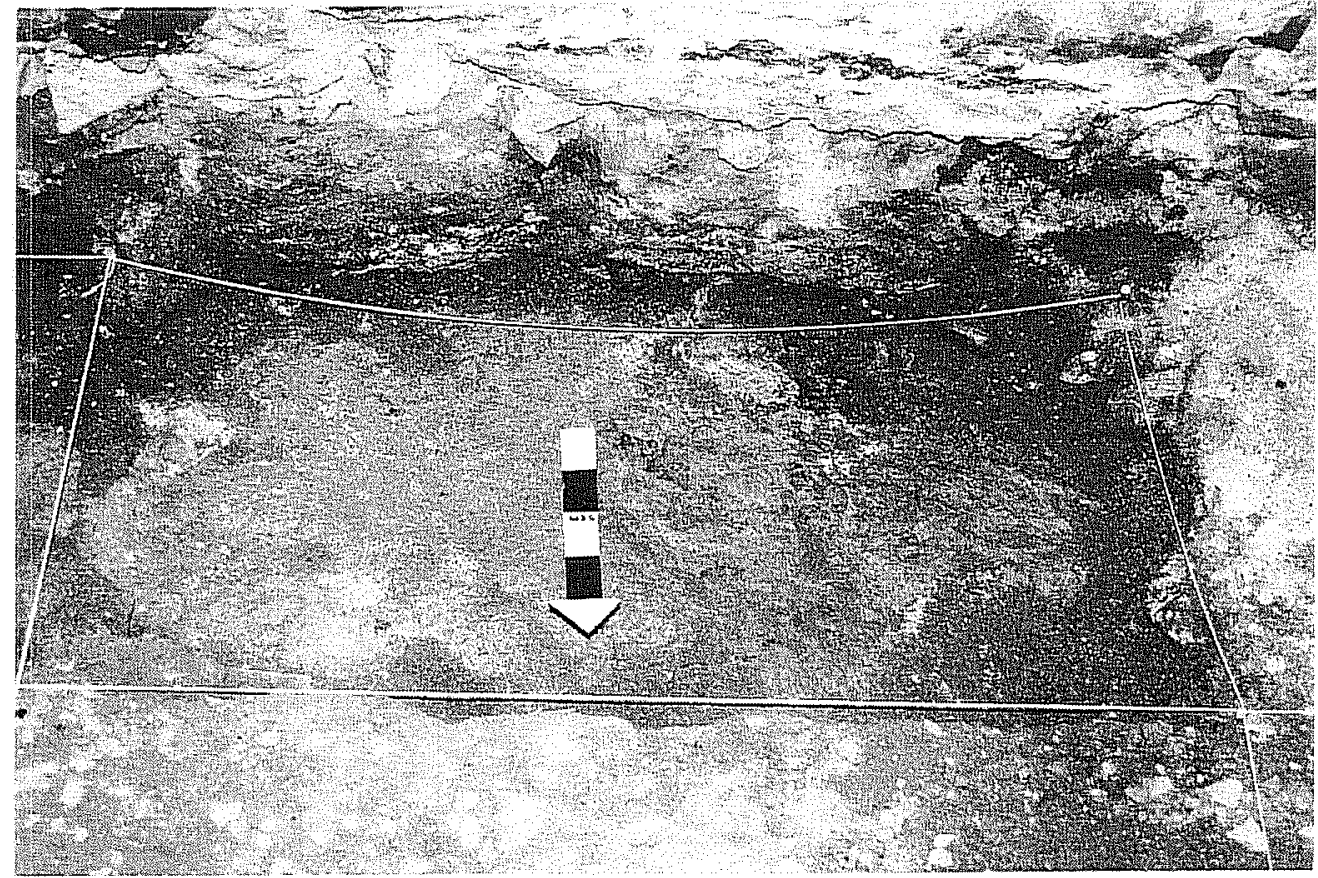

Figure 47. Unit 100N/100E in the western corner of the interior excavations at $114 \mathrm{~cm} \mathrm{bd}$. Lighter sediments in the center of the unit were found in patches throughout the interior excavations. other human remains in the Alamo have been disturbed in the past, as the bronze plaque in the center of the floor of the building testifies. In fact, as mentioned in the Methodology section, it is not unusual during excavations at the other missions to find disarticulated human bones in contexts both inside and outside church floors and/or designated cemeteries. During the current project, several small, disarticulated, individual bones were recovered during the screening of sediments from the interior, but were not positively identified as human until the entire assemblage was examined by Dr. Karin Wiltshke, a physical anthropologist from the National Museum of Austria,
The other areas of soft sediment were now a major concern, as no one wished to disturb any burials in the Alamo (Figure 49). It was decided to place plywood, cut to the specific measurements of the excavated area, over the ground surface, allowing the masons who would be cutting the wall to stand in the area without disturbing any burials or causing further collapse of sediments.

It should be noted that the extent to which the burial or burials represented by the bone seen below the excavation surface are intact could not be determined. Certainly

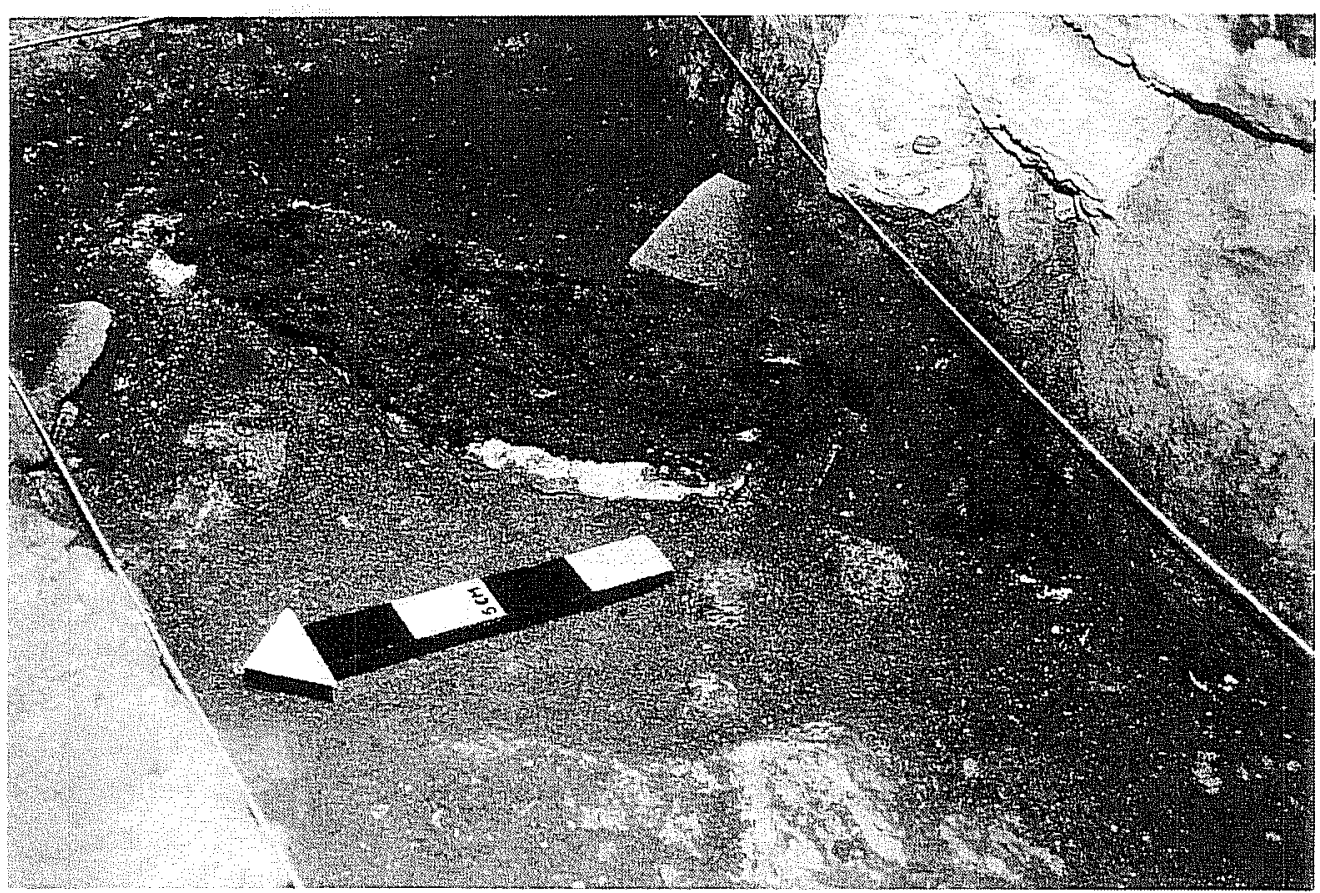

Figure 48. Asphalt-like material in the alcove, with a layer of white mineral salt crystals on its lower surface. 


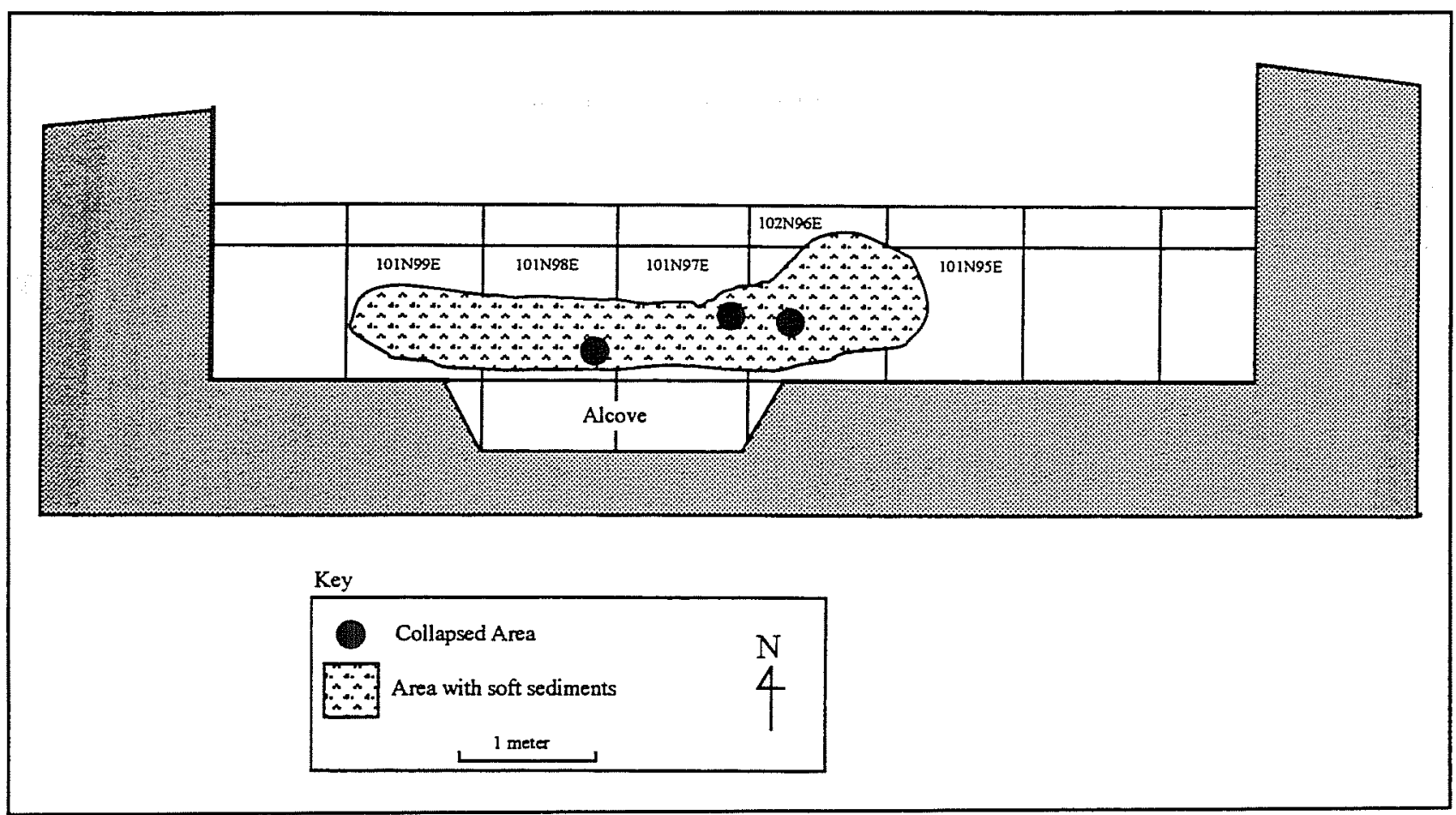

Figure 49. Plan view of interior excavation units with areas of soft sediments and location of holes in collapsed sediment.

Vienna. Appendix B contains a complete list of all elements Dr. Wiltshke identified as human. No further analysis was undertaken on these bones, and they were returned to the DRT for reburial when the interior excavation was backfilled.

Because of concerns expressed to DRT and CAR personnel by members of various Native American organizations, it is necessary to state explicitly that the only possibly intact burials encountered were those seen in collapsed areas, as described above. Even this bone cannot with certainty be shown to be part of an intact, previously undisturbed burial, because it was not excavated. In any case, the policy of the DRT and CAR was to avoid disturbance of human burials within the Alamo. The human bone recovered during the excavation was disarticulated, very small, highly scattered, and most ( 80 percent) was broken and fragmentary. Most (78 percent) was found in the units along the 96-98E line, where the deposits were very soft, and were scattered throughout the $40 \mathrm{~cm}$ of excavated sediment. Some bones were stained with tar, indicating they had been at or near the surface when the tar was laid down. After positive identification, all human remains were returned to the DRT for reburial. Upon completion of the interior excavations, all newly exposed portion of the wall were drawn (Figure 50) and photographed and the portion beneath the floor visible in the north wall of the excavation was profiled (Figure 51).

\section{Discussion}

The interior excavations indicate that the deposits above the level of the original foundation are disturbed. Some of this may be the remains of fill brought in to construct the ramp built in 1835 by General Coss. The extent to which older strata, containing earlier artifacts, were cleaned out of the building during the removal of the ramp by the U.S. Army is unknown.

It appears that the compact caliche layer was disturbed and mixed with more recent fill in some areas. Evidence for this disturbance includes the lenses of caliche, the association of Colonial period ceramics with these lenses, and the mixture of post-Colonial 

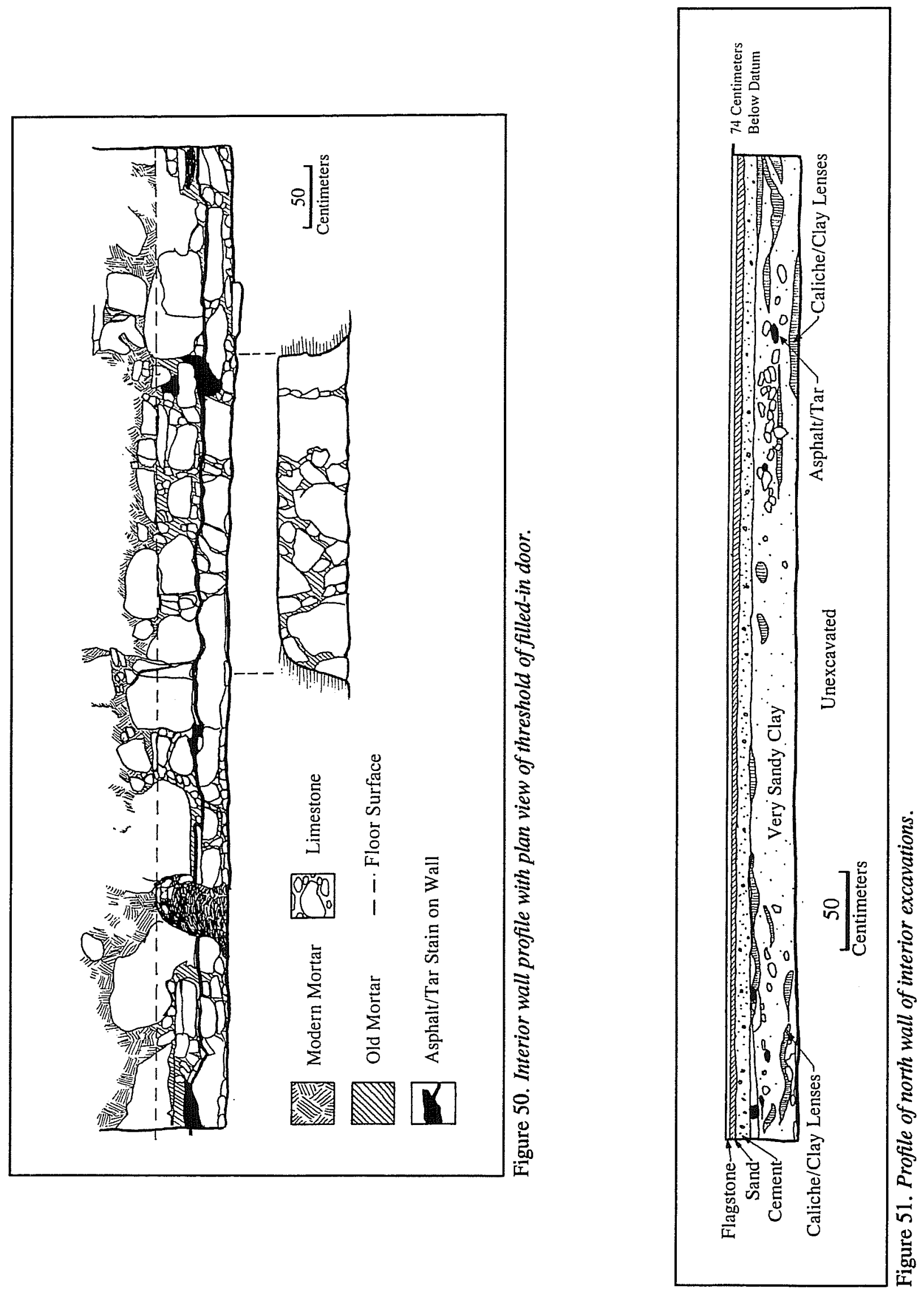
ceramics found in the same unit/levels. The extent to which rodent activity disturbed the area excavated is unknown, but is probably considerable, in light of the number of rodent bones recovered. The lack of distinctive pits in the excavated area also suggests that all or most of the disturbance is due to the burrowing of rodents attracted to the building by the materials stored there by the U.S. Army and Grenet.

The micromorphological study (see Appendix A) of matrix from the west wall of unit 101N95E revealed that the matrix was similar to the exterior deposits, however, the interior sample had been exposed to intense heat. Considering this, the absence of charcoal and fine-grained organic material in the sample was unexpected. The vertebrate remains recovered do not show evidence of this intense heat. Only two animal bones (both chicken-sized bird bones) showing evidence of burning were recovered from the interior. Even the human bone, which is believed to be of Colonial origin, shows no sign of heat damage.

The reason for the signs of intense heat in these sediments remains a puzzle. Though the building was gutted in the fire of 1861, the lack of charcoal and other signs of heat damage on the recovered human bone indicates that this is not the cause of the calcined limestone granules mentioned in the micromorphological study. This suggests that either all the bone (including the human bone) was deposited in the sediments after the fire or that the bone present at the time of the fire was protected from the heat in some manner. The former possibility is not as remote as it first seems. If much of the rodent activity evident in the soil took place after the 1861 fire, then the human bone may, at the time of the fire, have been still buried deeply enough to protect it from the heat. In that case, the disarticulated fragments of human bone in the upper layers would have only been moved there by rodent activity after the fire. A second possibility is also likely. There may have been even more fill inside the building at the time, placed there before the fire, and not extensively disturbed until after the burned remains (including, presumably, much of the original floor surface) had been removed, or there would have been more charcoal and burned bone mixed in the sediment. This extra fill would have protected the remaining bone from heat damage. There is some supporting evidence for this option. DRT records note that the paving of the floor involved "removing dirt in order to lay the foundation for the flagstone (Proceedings of the 46th Annual Meeting of the $D R T$ ). However, it is not possible to determine at this time which of the two possibilities is more likely.

Although some of the stones on the western side of the alcove floor are carefully smoothed to form a flat surface, no positively identification of a threshold could be seen on the exterior of the building at that point. The dirt which was found packed between the stones in the area where we believe the door was contained mid-nineteenth century artifacts, suggesting that the door had been sealed about the time the U.S. Army renovated the structure. 


\section{Chapter Six}

\section{Artifacts}

A rtifacts recovered during the project were bagged according to provenience, washed, cataloged, and labeled when appropriate. For the purposes of analysis, the artifacts are classified into general categories according to assumed function. These categories are: Kitchen/Household, Personal/ Clothing, Activities, Barn/Workshop/ Garage, Arms, Lithics, Utilities, Construction, and Miscellaneous. Faunal remains were also washed, bagged, and analyzed. Provenienced lists of all recovered artifacts, arranged by categories, are given in Appendix C.

Within each functional category, artifacts are grouped by provenience. As discussed in Chapter Five, both the interior and exterior excavations contained mixed sediments. Although several hand-dug test pits were excavated in the exterior area, the artifacts recovered made it clear that the area had been disturbed prior to the 1995 excavations, probably frequently and recently. Therefore, in some cases artifacts are divided only into Exterior and Interior excavation proveniences.

In other cases, artifacts from the exterior are divided into three groups: artifacts recovered north of the police station foundation, designated Area A; artifacts recovered north of the concrete foundation, designated Area B; and artifacts recovered from the entire area south of these foundations, designated Area C (see Figure 21). Although interior excavations also revealed some mixing of sediments, it was neither as serious nor as recent as the disturbance seen outside. Certainly it had not been disturbed by human activities since 1936 when the floor was paved. Therefore, when more specific provenience data is considered important, artifacts from the interior will be divided into their respective excavation units. However, since some of the interior units were dug in 10-cm levels and some were not, all artifacts from a unit are considered together. See Figure 23 for a diagram of the interior excavation units.

\section{Kitchen/Household}

Although the Alamo church was never, as far as is known, used as a habitation, several houses were known to have been built nearby during the late 1800 (see Figure 10). The saloon which occupied the building next door during part of the late-nineteenth century could also be a source of domestic ceramics and bottles. The use of the Alamo as a warehouse may also have contributed to the presence of household-like debris.

\section{Ceramics}

The ceramics considered in this section are presumed to be utensils made for use in the kitchen and similar areas of the house. Ceramics used for other purposes, such as toys, electrical insulators, toilet facilities, and building materials are considered in the appropriate sections.

Detailed information concerning production methods and terminology are not included in this report. The reader interested in more information on ceramics in general is referred to Rice (1987); for more 
information on ceramics commonly found in local Colonial period sites in San Antonio see Dial (1992), Ivey and Fox (1981), and Meskill (1992). A useful chart of ceramic dates for the area is given in Hard et al. (1995:47). A glossary of terms and ceramic types used in the description and discussion follows.

\section{Terms}

\section{Burnished}

A method of producing a very smooth, polished appearance on ceramics by rubbing the dry but unfired clay with a smooth object to compact the surface (Rice 1987:473).

\section{Earthenware}

A general term for pottery fired at temperatures (900$1200^{\circ} \mathrm{C}$ ) too low to vitrify (partially melt) the clay. Earthenwares have relatively soft, crumbling texture. If unglazed they are quite porous (Rice 1987:5).

\section{Glaze}

A method of waterproofing and decorating ceramics. A glaze is a thin coating of minerals applied to fired pottery which is then fired a second time. The glaze melts during the second firing to form a waterproof seal over the surface (Rice 1987:476). Different combinations of minerals in a glaze result in various colors and degrees of hardness. The most common glazes on earthenwares are of lead and tin (Rice 1987:12).

\section{Majolica}

A low-fired earthenware with an opaque tin glaze, common in fifteenth- to nineteenth-century European countries and their colonies. The decorative patterns on these ceramics are often temporally diagnostic. Spanish majolicas are found on Colonial period sites in San Antonio.

\section{Paste}

The fired clay which forms the body of a piece of pottery.

\section{Porcelain}

Ceramics made from relatively pure kaolin clays and fired at high temperatures $\left(1280-1450^{\circ} \mathrm{C}\right.$ or higher). Porcelains have a very fine-textured white paste, appearing almost glass-like.

\section{Refined wares}

These ceramics are made from clays from which the larger particles have been removed, resulting in a very fine texture. Refined clays are fired at high temperatures, and are at least partially vitrified. Refined wares recovered during this project were of three types: whitewares, porcelain, and stoneware. In Texas, refined wares are usually from post-Colonial periods (Hard et al. 1995:45).

\section{Salt glaze}

A glazing technique of European origin, used on stoneware. During firing of the stoneware, common rock salt is thrown into the firebox of the kiln. The sodium in the salt vaporizes and combines with the silica in the clay surface, forming a thin glaze of silicate glass (Greer and Black 1971:5).

\section{Slip}

A liquid suspension of clay and water used to coat pottery before firing (Rice 1987:482). Slips can be many different colors. One variety of slip seen on stoneware from this project is Leon slip, which is made from a particular deposit of clay in southern Bexar County and has a distinctive range of colors.

\section{Stoneware}

A pottery fired at temperatures between $1200-1350^{\circ}$ $C$, which causes partial vitrification of the clay (Rice 1987:6).

\section{Temper}

Material added to clay to make it less likely to crack or split during drying and firing. Tempers can be almost any material: organics such as bone, shell, and grass; minerals such as sand or volcanic ash; or even crushed pottery sherds (Rice 1987:407-408). The most common tempers seen in ceramics produced in South Texas are sand and crushed bone. 


\section{Unglazed}

Ceramics made by firing the clay without a glaze. The surface of unglazed earthenwares is porous.

Whiteware

A ceramic made from refined clay with a white paste, fired at a high temperature (Hard et al. 1995:45). Decorated or undecorated, these wares are very common in post-Colonial contexts.

\section{Ceramic Types Recovered During Project}

A total of 245 ceramic sherds was recovered during the project. Ceramics are discussed by provenience and type.

\section{Unglazed Earthenwares}

\section{Goliad ware}

An unglazed, bone-tempered, low-fired ceramic made during the Colonial period, presumably by Native Americans at the missions. No method is currently available to distinguish Goliad ware from the ceramics made in this area during the Late Prehistoric period (commonly referred to as Leon Plain ware), which suggests that Goliad ware is a continuation of this pottery-making tradition from prehistoric times (Dial 1992:29; Fox et al. 1976:67). Goliad ware varies in color from buff to red on the surface and paste ranges from reddish yellow to reddish brown to pinkish gray. A dark gray band in the center of the paste is common, resulting from incomplete firing (Dial 1992:29). This ware continued in use in San Antonio until after 1833 (Fox 1977; Hard et al. 1995:48).

\section{Tonala}

A fine-grained, thin-walled, slip painted, burnished ware. These ceramics are made from a particular clay from Jalisco, Mexico (Dial 1992:32).

\section{Valero}

An unglazed, soft, sandy paste earthenware, with a surface color of pink to gray. A reddish brown slip is painted on the rim of some pieces. The type is also known as Red on Pink (Dial 1992:31) and Red on
Orange (Greer 1967:19). Association of this ware with dateable artifacts suggests dates of 1730 to 1760 (Ivey and Fox 1981:33). The abundance of this fragile ware on San Antonio sites suggests local manufacture (Dial 1992:31).

\section{Glazed Earthenwares}

\section{Lead-glazed}

These ceramics are soft earthenwares with a leadbased glaze, imported to San Antonio from the interior of Mexico (Meskill 1992:23). They can be divided into two types. One is a thick-walled utility ware with a sandy orange paste, uneven yellow or green glaze, and occasionally a green or brown band around the rim or base (Hard et al. 1995:44). The other is a thin-walled variety, often called Galera, which was used for chocolate and bean pots. The paste of this variety is fine-grained, the glaze is often a shade of orange or reddish brown, and it is often decorated under or over the glaze with floral designs or bands in cream, brown, or green (Dial 1992:34; Hard et al. 1995:44). Lead-glazed wares are considered post-1750 in San Antonio (Ivey and Fox 1981). Although they became less popular after the end of the eighteenth century, they continued to be made, and similar wares are made today.

\section{Tin-glazed}

These earthenwares, usually called majolicas, have a buff to orange paste and an opaque tin glaze, which is usually decorated. Mexican majolica was imported to San Antonio throughout the Colonial period and until the early nineteenth century. The decorative patterns of Mexican majolicas have named types and can be used to date the manufacture of the ceramic (Hard et al. 1995:45).

Refined wares

\section{Whiteware}

This is a high-fired ceramic with a white paste and usually a clear glaze. Whitewares are often undecorated. It is important to remember that many areas of decorated pieces are plain, and there is no way to distinguish between sherds from plain areas and sherds from undecorated pieces. Decorations are 
divided into eight types, by the method used to apply the decoration.

1) Transfer print uses an etched copper plate to print a design on special paper which is then used to "transfer" the color to the ceramic. The piece is then glazed and fired. This kind of decoration was especially popular in the late-eighteenth and early nineteenth centuries (Hard et al. 1995:48).

2) Decal (also called decalcomania) is a type of transfer printing. A design, often multicolored, is printed on thin tissue paper, adhesive is applied, then the paper is transferred to the glazed ceramic (Durrenberger 1965:10). Because the design is applied over the glaze and may rub off, decal decorations are often in poor condition on sherds from archaeological sites.

3) Handpainted designs are applied before glazing. This decoration was popular during the early nineteenth century (Dial 1992:41).

4) Spongeware/spatterware decorations are pigments splattered on the ceramic or applied with a sponge. This method was most popular between 1820 and 1850 (Robacker and Robacker 1978:32). Cut sponge-ware was made by dipping a piece of sponge, with a simple pattern cut into it, into pigment, and stamping the pigment onto the ceramic. This method was introduced to British commercial potteries about 1845 (Robacker and Robacker 1978:98) and had passed the peak of its popularity by 1870 (Dial 1992:44).

5) Edgeware has a design molded onto the edge, and a green or blue pigment spread on the design. Edgewares date from 1780 to 1900 , but specific types can be dated more closely (Dial 1992:39).

6) Banded slip has colored slips applied in bands before glazing and firing. The slip is sometimes mixed or swirled or has other colors dripped on it. This was a relatively cheap ware, popular from the early eighteenth to the mid-nineteenth centuries (Dial 1992:39-41).
7) Repoussé has embossed designs and may or may not occur with other decorations.

8) Gilding is a thin layer of gold applied in some (usually oil) suspension and then heated enough to burn off the suspension fluid. Gilding is often seen with decal and occasionally with repoussé.

Other less popular methods of applying colors and/or glazes were also used.

\section{Porcelain}

Porcelains are made with the most highly refined clays. Kaolin clay creates a pure-white paste, and vitrifies almost completely at high temperatures. Depending on the other minerals in the clay and the firing temperature, porcelain can be translucent and glass-like. Porcelains can be decorated using any of the techniques mentioned for whitewares, however, the most common decorations are transfer printing, decal, and solid-color glazes.

\section{Yellowware}

This type of molded ceramic, used for utilitarian purposes, was an early success for American commercial potters beginning about 1828 and continuing until the 1940s (Abramovitch 1995:99). The paste is usually a pale yellow, and the alkaline (or occasionally lead) glaze intensified the color (Ramsay 1976:148). Yellowware bowls and other utility wares were common items in late-nineteenth- and early twentieth-century mail order catalogs (Raycraft and Raycraft 1975:Plate 16).

\section{Stoneware}

Stonewares are made from clays able to withstand firing at temperatures which partially vitrify them, usually between $1200^{\circ}$ and $1390^{\circ} \mathrm{C}$ (Greer 1981:15). The paste varies from nearly white to red-brown and grays, and is generally waterproof even if unglazed (Greer 1981:15). Stoneware was imported to San Antonio from both Germany and England, and North American potteries were also producing stoneware (Greer 1981:19). After the Civil War, several potteries were producing stoneware in the San Antonio area (Greer 1981). The Meyer Pottery near 
San Antonio produced large quantities of stoneware between 1887 and 1962 (Greer and Black 1971:1).

\section{Exterior Excavations}

A total of 195 ceramic sherds was recovered during the exterior excavations. This represents 79.6 percent of the total ceramics. Of these, 114 (58.5 percent) of the exterior ceramics were from at least two very similar lead-glazed pots (Figure 52). The latter were from the level at the top of the west (police) foundation, on both sides of that foundation, suggesting that the sherds were deposited after removal of the building in 1896 .

The 114 sherds represent approximately 70 percent of one pot (Figure 52a) and 40 percent of the other (Figure 52b). Forty-one sherds (36.0 percent) could not be mended. Both pots have molded bottoms and wheel-thrown tops. The rounded lower part of the pots was left unglazed on the exterior. The hand- painted design on each pot is the same color and is very similar. The second pot (Figure 52b) is thicker and appears poorer made than the first (Figure 52a).

The pots are chocolateras, straight-sided pots which bulge out at the bottom, with one handle and a spout made by bending the rim outward slightly. Chocolateras were used for making and drinking hot beverages (Barnes 1975:44). The form is thought to be a copy of copper vessels brought from Spain. The dating for this type of vessel is very broad, roughly from 1790 to 1940 (Barnes 1975:45).

\section{Area A}

The only sherd found inside the west foundation, other than 51 of the chocolateras fragments, was one rim sherd from a small Tonalá earthenware bowl (Figure 53a). The bowl has a buff-colored surface, with a light gray, fine-textured sandy paste. The rim is painted reddish brown and is scalloped on the exterior. Part of a design in reddish brown and black is visible on the exterior of the sherd.

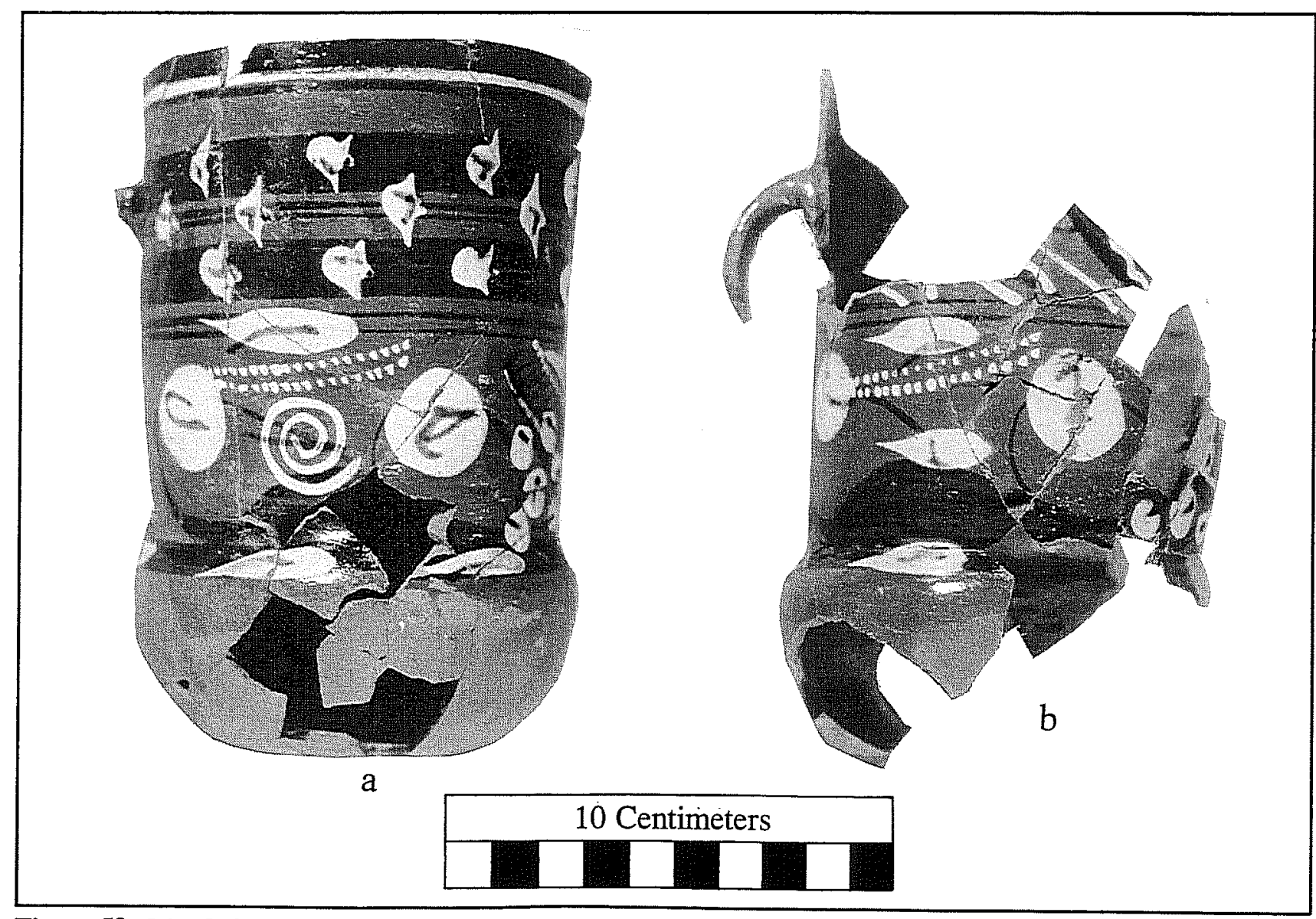

Figure 52. Mended chocolateras from exterior excavations. 
Area B

Ten ceramic sherds were recovered from inside the east foundation.

1) Two body sherds of lead-glazed earthenware. One tiny sherd is decorated with an orangered slip on the interior and painted brown on cream on the exterior. The glaze has a slight olive green tint. The piece is too small to be sure, but is probably an example of what Barnes (1975:44-45) calls Polychrome Jarros, manufactured between 1750 and 1900. The second sherd has an unglazed exterior. It appears very similar to the sherds from the chocolateras discussed above, but is thicker and has a slightly lighter paste.

2) An edgeware rim sherd (Figure 53b). The sherd is embossed with a feather design along the rim and a scalloped design below. The color is blue, below the glaze, and the edge does not appear to be scalloped. These characteristics suggest that the sherd dates between the 1840s and 1860s (Miller and Hunter 1990:117).
3) A whiteware rim sherd with the barely visible remains of two red or dark pink decaldecorated lines.

4) Four body sherds of undecorated whiteware. One is a fragment of a high, rounded foot ring from a bowl (Figure 53c), a distinctive English style popular in the 1830 s to 1840 s.

5) A body sherd of undecorated porcelain.

6) A stoneware body sherd with a Leon slip interior and salt-glazed exterior (Figure 53d). The sherd was made by the Meyer pottery, which operated from 1887 to 1962 near Atascosa, Texas, southwest of San Antonio (Greer and Black 1971:1). This potter used the distinct Leon slip, made from clays mined from the banks of Leon Creek in an area now on Kelly Air Force Base, in southeastern Bexar County. The glaze has variable color, depending on the thickness of the slip and the firing temperature (Greer and Black 1971:5-6). The glaze on this sherd is a brownish yellow to reddish yellow. Salt glaze is not believed to have been used by the Meyer pottery after about 1895 (Greer and Black 1971:5).

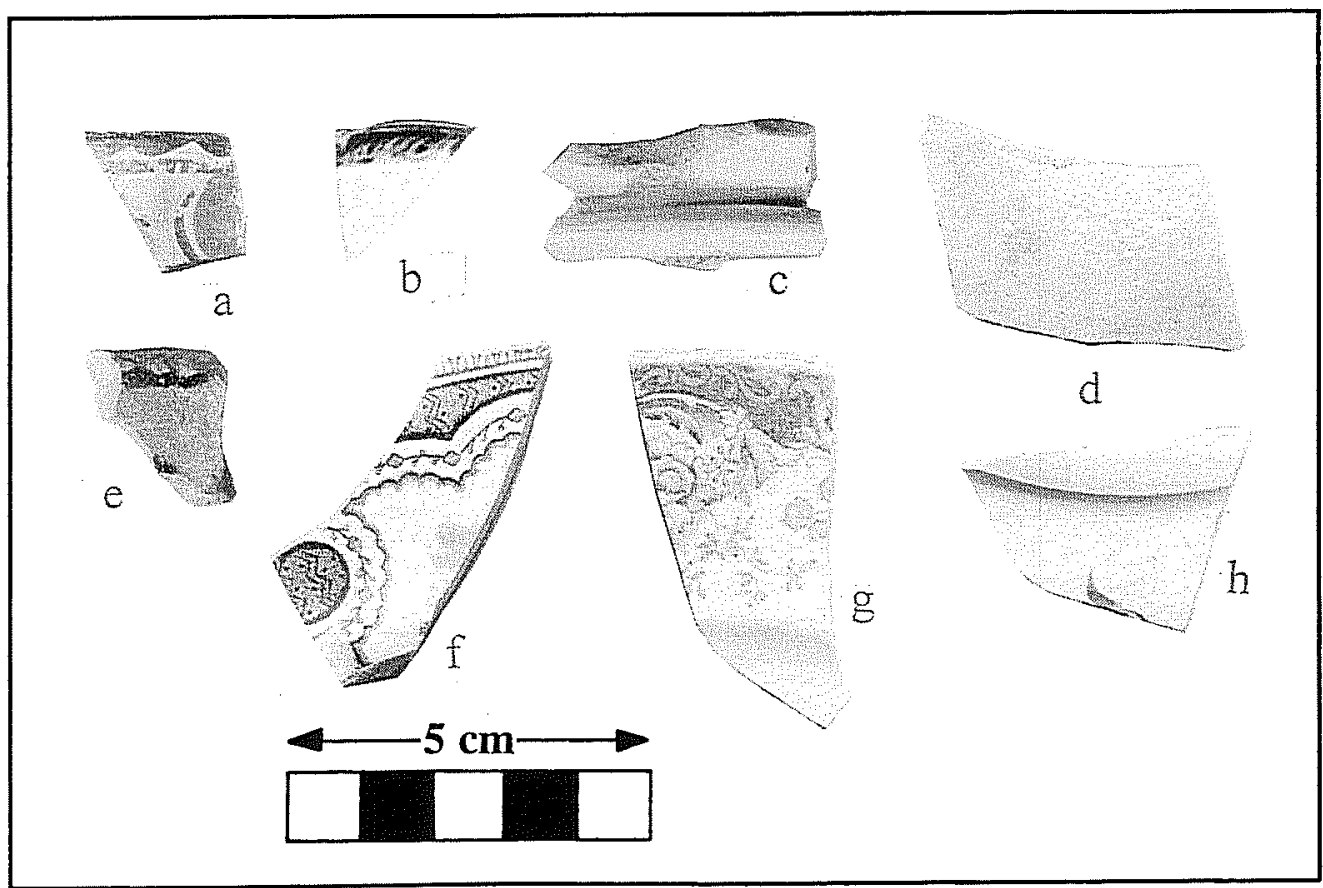

Figure 53. Ceramics recovered from exterior excavations. a. Tonala earthenware; $b$. blue edgeware; c. undecorated whiteware; d. salt-glazed stoneware; e. lead-glazed ware with green rim; f. purple transfer; g. green transfer; h. handpainted. 
Area C

Of the ceramics recovered in this area, 63 were from the two chocolateras. The other ceramics were:

1) Two body sherds of Goliad ware. One has soot on the exterior.

2) One body sherd of Valero ware. No decoration is seen on this sherd.

3) A body sherd of Tonalá ware.

4) Two lead-glazed sherds, both thick utility wares with a sandy paste. One is a body sherd with a yellow glaze on the interior only. The other is a foot ring bowl fragment with a light yellow glaze, and a bit of green glaze decoration (Figure 53e). Both sherds are almost identical to ceramics found during the excavation of a lime kiln at Rancho de Las Cabras (Ivey 1983:1). This site, located southwest of Floresville, Texas, is the remains of the ranch associated with Mission Espada, the southernmost of the five San Antonio missions. The Rancho de Las Cabras kiln is thought to have been used sometime after 1772 (Ivey 1983).

5) Two rim sherds of transfer-printed whiteware. The first is purple, a color introduced in 1826 (Davis and Corbin 1967:17), and shows a mixture of geometric and floral designs (Figure 53f). The second sherd is a light green, has a slightly scalloped edge, and shows a floral motif (Figure 53g).

6) A handpainted body sherd, possibly from a cup (Figure 53h). The sherd has only a fragment of the design, a green leaf and black stem.

7) Two spongeware sherds. One is a rim sherd with a purple-red line near the rim and part of a cut-sponge design in green below (Figure 54a). The other is a tiny body sherd with a purple cut-sponge design (Figure 54b).

8) Two banded-slip sherds, both very small. One is a body sherd with only the blue slip on the exterior. The other is a rim sherd with an undecorated edge and a pink line above the blue slip.

9) Two repoussé sherds. One is a rim sherd from a bowl, with a row of small dots embossed on the edge. The other is a body sherd embossed with a single row of scallops.

10) A whiteware rim sherd with a gilded line on the outer edge.

11) Twenty-four undecorated whiteware sherds. Of these, six are rim sherds, four have foot rings, one is a handle fragment, and one is part of a saucer. The latter has a scalloped edge, foot ring, and the outer edge of a maker's mark too fragmentary to identify.

12) A yellowware rim sherd from a large mixing bowl with a turned rim and the remains of a white band just under the rim. It is quite similar to several bowls pictured in Raycraft and Raycraft (1975:Plate 16).

13) A porcelain rim sherd, scalloped, with an unusual decoration (Figure 54c). At the edge is a scroll design which appears to be either incised and filled with a clay which becomes opaque when fired, or painted with opaque white paint. The glaze covers the
Figure 54. Ceramics recovered from exterior excavations. a. cut spongeware, red and green design; b. cut spongeware, purple design; d. porcelain; d. decal-decorated porcelain; e, f. porcelain with floral design. 
design and leaves the surface smooth. The result is a subtle white-on-white pattern.

14) Six sherds of decal-decorated porcelain. Two of these mend to form part of a cup (Figure 54d). Most of the colors in the design have rubbed off, but the floral motif is discernible. Part of the design is gilded. Two other pieces which mend are part of a plate or saucer with a gilded rim (Figure 54e). The floral motif appears to be the same as that on the cup fragments. The final two pieces also appear to have a floral motif. Little of the design remains on one, but the other shows a leaf (Figure 54f).

15) Two sherds of porcelain with a solid-colored slip under the glaze. One is a body sherd with pink exterior. The other is a bottom fragment of a small, straight-sided jar with a deep blue translucent color on the exterior.

16) Eight sherds of undecorated porcelain.

17) Six stoneware sherds, five of which appear to be from a single vessel. They have a buffcolored slip and a clear lead or alkaline glaze inside and out; however, a fragment of the base is unglazed on the exterior (bottom). One piece has an small incised zigzag design cut through the slip (Figure 55a). The sixth stoneware sherd has Leon slip on both sides.

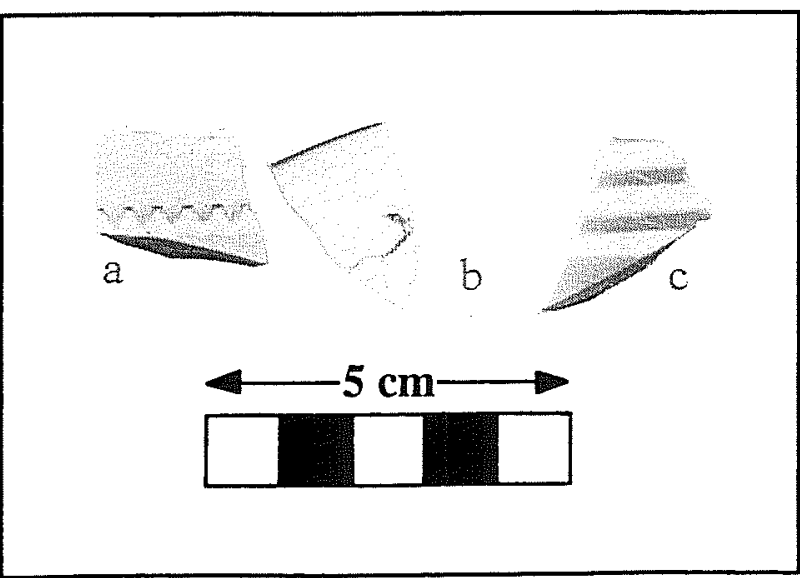

Figure 55. Ceramics from exterior excavations. a. stoneware with a zig-zag design; b. porcelain with decal design; c. blue and green banded slip.
Monitored Excavations East of the South Transept

1) A porcelain rim sherd with the remains of a decal decoration with a brown color (Figure 55b).

2) An undecorated whiteware body sherd.

Test Pits Along South Wall of Apse

1) A body sherd of banded slip, with blue and olive green bands (Figure 55c).

2) Two undecorated whiteware sherds, one of which is a large fragment of a saucer.

3) An undecorated porcelain sherd.

\section{Interior Excavations}

Fifty ceramic sherds were recovered from the interior excavations (20.7 percent of total). They are listed by excavation unit.

100.5 N/97E

1) An undecorated whiteware sherd with a partial maker's mark, ". . . INA", stamped in black ink under the glaze (Figure 56a). The word CHINA is included in many backmarks, making identification impossible.

100.5N/98E

1) Six undecorated whiteware sherds, including one handle fragment and two rim sherds. One of the rim sherds is from a small saucer.

\section{N93E}

1) A rim sherd of sandy paste, lead-glazed earthenware (Figure 56b). The glaze is dark yellowish green, a type used in the eighteenth century (Barnes 1975:28).

\section{N/94E}

1) A very small whiteware body sherd.

\section{N/95E}

1) A small Valero body sherd.

2) An undecorated whiteware rim sherd.

3) A stoneware body sherd with a lead-glazed exterior and unglazed interior (Figure 56c). Incised writing is found on the exterior, but 
the fragment is too small to identify. It is probably from a gin jug or similar bottle.

4) An undecorated porcelain body sherd.

\section{$101 \mathrm{~N} 96 \mathrm{E}$}

1) Three whiteware sherds, including two rim sherds and a handle fragment. This handle fragment is the same color, size, and shape as the one recovered from unit 100.5N98E, but they do not mend.

\section{$101 N / 97 \mathrm{E}$}

1) An undecorated whiteware body sherd.

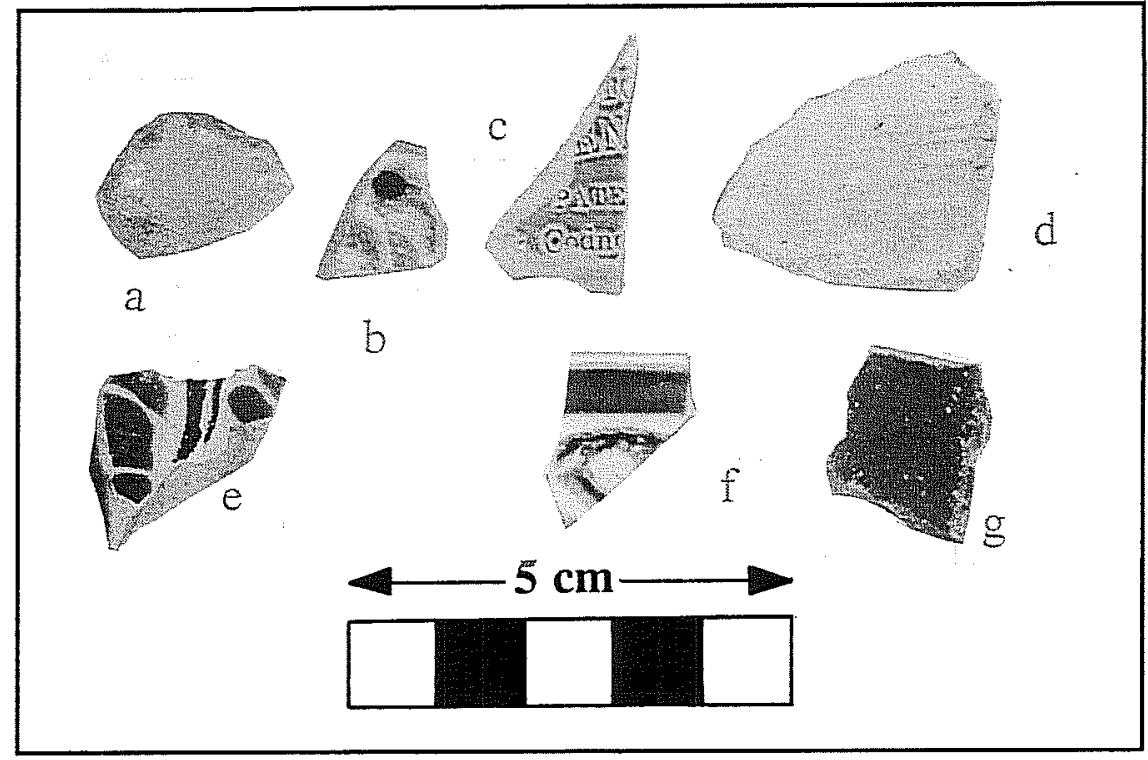

Figure 56. Ceramics from the interior excavations. a. undecorated whiteware with partial maker's mark; b. sandy paste, lead-glazed earthenware; c. lead-glazed stoneware; $d$. possible olive jar; e. Tucson Polychrome majolica; f. cut sponge whiteware; g. Goliad ware.

$101 \mathrm{~N} / 98 \mathrm{E}$

1) A thick, unglazed body sherd with a sandy paste and a thin white slip on the exterior (Figure 56d). This sherd is probably from an olive jar-a large, crudely made, unglazed storage vessel used throughout the Colonial period (Deagan 1987:30). The thickness $(11.5 \mathrm{~mm})$ and the thin slip on the exterior suggest that this sherd is from an olive jar dating from ca. 1730 to 1770 (Deagan 1987:33-34).

2) One body sherd of Tucson Polychrome majolica (Figure 56e). The colors are dark green and dark brown/black on a light buff background. This majolica is a late variety, dating about 1820 to 1850 (May 1972:36).

3) A rim sherd of cut sponge whiteware (Figure 56f). The band at the rim is a medium blue and the cut sponge design is green.

4) Seven undecorated whiteware sherds, including part of the rim and foot ring of a saucer, and five rim sherds.
$101 \mathrm{~N} / 99 \mathrm{E}$

1) A body sherd of Goliad ware, with a red slip on the interior and signs of smoke damage on the exterior (Figure 56g).

2) A body sherd of Galera ware. The interior has an orange/brown slip under a clear glaze. The exterior is decorated with cream, green, and orange/brown under the glaze and a dot of brown paint over the glaze. This type is called Clear Glazed ware by Barnes (1975:31), and Light Green-on-cream-onorange by Greer (1967:25). It dates to the first half of the nineteenth century (Barnes 1975:32).

3) Two body sherds of undecorated whiteware.

4) A stoneware body sherd. The sherd has a light reddish brown surface and is salt glazed on the exterior and slip glazed on the interior, a common practice before the end of the nineteenth century (Greer 1981:17).

\section{$101 \mathrm{~N} / 100 \mathrm{E}$}

1) Two Valero ware body sherds. One is thick, with a light orange/pink paste and a slightly darker thin slip (Figure 57a). There is small part of what may once have been an incised 

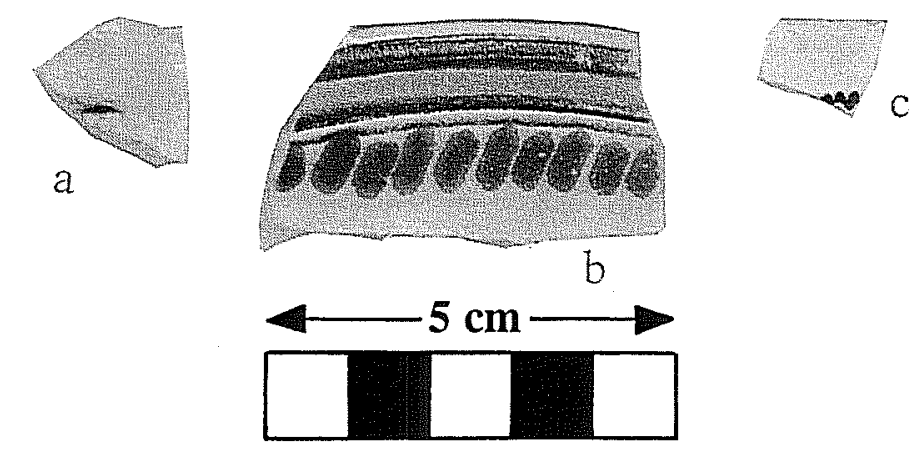

a

Figure 57. Ceramics from the interior excavations. a. Valero ware; b. majolica, orange band with green petals; c. majolica, tin-glazed rim sherd.

design, however, it may merely be a flaw in the surface of the vessel. The other sherd is thinner, with a light orange paste and finergrained temper.

2) A majolica rim sherd (Figure 57b), with a design variously called Orange Band Polychrome Type II (Barnes 1972:12), Orangeline Polychrome (May 1972:36), and Nopaltapec Polychrome (Deagan 1987:88). This is a variety of Aranama Polychrome, a style which began in the late eighteenth century and continued to the middle of the nineteenth century. May (1972:34) prefers to use the word "tradition" for Aranama because several varieties developed from the original. The variation seen on this sherd is dated 1820 to 1850 (Barnes 1972:13; May 1972:36).

\section{$102 \mathrm{~N} / 94 \mathrm{E}$}

1) A small body sherd of the thin-walled Galera type. Both exterior and interior surfaces are orange.

\section{$102 \mathrm{~N} / 95 \mathrm{E}$}

1) A tin-glazed majolica rim sherd (Figure 57c). A small amount of decoration-a brown zig zag line-is seen on the broken edge. Too little of the decoration remains to identify this sherd, but it is reminiscent of an unnamed, undated, thin-walled type of majolica with small brown and blue decorations found at Mission San Juan Capistrano (Schuetz 1969:57) and Mission Rosario (Gilmore 1974:48).

\section{$102 \mathrm{~N} / 96 \mathrm{E}$}

1) A thick Valero ware body sherd with a sandy paste and no slip.

\section{N97E}

1) A small body sherd of Goliad ware which has been badly burned on both sides

2) Two body sherds of Valero ware. The sandy paste of both is a similar light orange/pink; however, one has a slightly darker slip on both sides and the other does not.

3) A small sherd of sandy paste earthenware with a clear and very thin lead glaze.

4) A sherd of thick-walled tin-glazed majolica, with part of a heavy foot ring (Figure 58a). The sherd is undecorated, with a creamcolored surface. Lister and Lister (1974:30) state that plain undecorated majolicas like this were probably the first to be brought to the New World, but continued to be made throughout the Colonial period and well into the nineteenth century. They were usually in small bowls, cups, albarelos (deep-welled, brimmed plates) or chamber pot forms (Lister and Lister 1974:30). This sherd is probably from an albarelo.

\section{$102 \mathrm{~N} / 98 \mathrm{E}$}

Four undecorated whiteware sherds, two of which are rim sherds which mend. A third piece has part of a maker's mark, too fragmentary to identify, printed in black ink under the glaze. All four sherds show a green (possibly a copper oxide) discoloration under the glaze in places along the broken edges. Whether this was the result of an accident during manufacture or happened after burial was not determined. 


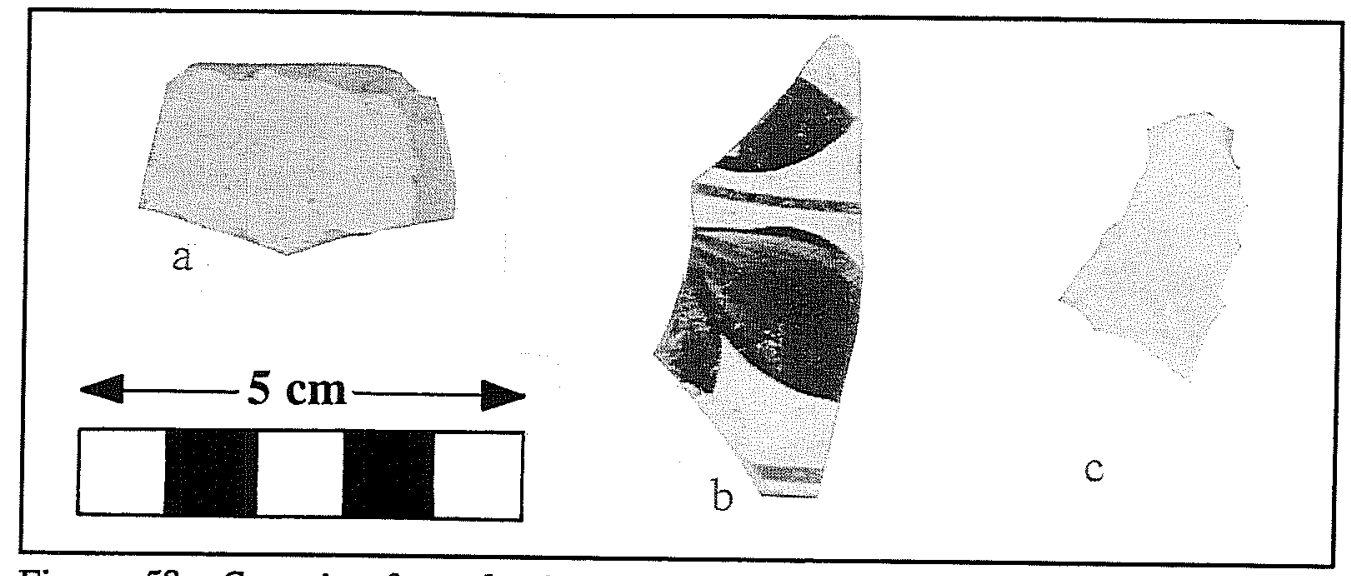

Figure 58. Ceramics from the interior excavations. a. undecorated majolica; b. handpainted ware with red, green, and dark brown design; c. undecorated whiteware with partial impressed Davenport mark.

\section{$102 \mathrm{~N} / 99 \mathrm{E}$}

1) A body sherd of undecorated whiteware.

Inside the Wall

As discussed in Chapter Five, during the cutting of the wall seven artifacts were recovered from dirt stuffed between the stones inside the south wall of the south transept.

1) A handpainted whiteware rim sherd (Figure 58b). This sherd appears to be from a cup or a steep-sided bowl. The decoration is on the exterior, except for a thin red line just under the rim in the interior. The exterior also has the red line near the rim, and parts of a pattern with green leaves and a dark brown/black stem.

2) An undecorated whiteware body sherd, with part of an impressed maker's mark (Figure 58c). The mark (Figure 59) identifies the ceramic as having been made by one of the Davenport companies, in Staffordshire, Great Britain. The Davenport pottery, operating under various firm names, was in operation from 1794 to 1887 (Lockett 1972). The maker's mark is impressed with a pattern number over the Davenport name and anchor design, a style which was in use between about 1850 and 1880 (Lockett 1972:111). The date of

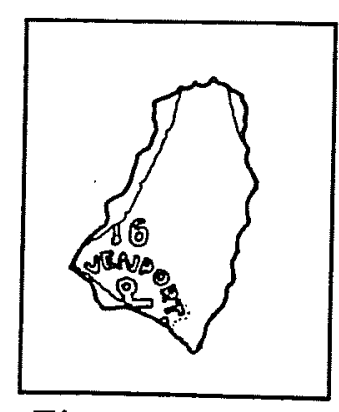

Figure 59. Davenport maker's mark. Shown actual size. manufacture is usually impressed on each side of the anchor in this mark style, but unfortunately that part of the mark is missing. After about 1860, Davenport was manufacturing mostly porcelain (Godden 1965:116). This sherd is may be an exception to that rule, but is more likely to have been made between 1850 and 1860 .

\section{Discussion}

Dates for the ceramics from the exterior excavations span a 250-year period, from Colonial Goliad ware to undecorated whitewares. The latter may have been buried there as recently as 1976. Overall, the ceramics represent kitchen trash scattered more or less randomly both horizontally and vertically. Considering the amount of fill added to the area and the degree to which it was disturbed, this is not surprising. Only seven sherds (3.6 percent) from the exterior excavations are definitely Colonial in age (excluding the lead-glazed Galera type, which cannot be dated with certainty). The small number of Colonial ceramics suggests that the Colonial levels outside the south transept have not been seriously disturbed.

Dateable ceramics in Area B show a marked concentration of ceramics from the nineteenth century, almost entirely from the 
first half of the century. In fact, the only dateable ceramic which is definitely from the second half of the nineteenth century is the stoneware with a Leon slip interior and salt glaze exterior (Figure 53d). This piece, made sometime between 1887 and about 1895 (Greer and Black 1971:5), was recovered from a hand-dug excavation unit above the brick floor, between 10 and $20 \mathrm{~cm}$ bgs. All other dateable ceramics from this area are early nineteenth century, and all come from the grey caliche/clay level between 55 and $65 \mathrm{~cm}$ bgs. Thus this caliche/clay stratum may be an intact early nineteenth-century level.

The matrix in the exterior excavations, with the possible exception of the caliche/clay level in Area B, has been disturbed often enough to contain a wide range of ceramics. The ceramics are evidence of the long use of the area around the Alamo shrine.

Ceramics from the interior excavations have much the same range of dates as those from the exterior. Of the 50 sherds from the interior excavations, 26 (52.0 percent) were undecorated whiteware and porcelain, which can be dated only very roughly as postColonial. Of the remaining sherds, 16 (32.0 percent of the total) are from the Colonial period, while the remaining 9 (18.0 percent) are nineteenth century in origin.

The majority of the Colonial period ceramics are associated with the areas which are believed to have been disturbed, probably by rodent activity. Areas which did not appear disturbed-i.e., did not have patches of caliche mixed into younger sediment-did not have Colonial period artifacts. The possibility exists that Andrade and the U.S. Army did not completely destroy the Colonial levels in the interior when they cleaned out General Cos's ramp, and that relatively intact Colonial levels lie below or in the hard-packed caliche encountered just below the level of the top of the foundation stones. Only further excavations can determine if this is true.

\section{Glass}

A total of 751 glass fragments was recovered during the excavations (Table 2). The glass listed as "Black" is actually a very dark green that appears black unless held to the light. The category "Other" includes one sherd of yellow glass and one lump of melted clear glass.

Because of the differences in excavation technique and artifact recovery between the interior and exterior excavations, direct comparison of the glass recovered from the two areas would be of limited usefulness. Briefly, there is little difference in terms of percentage of glass colors from the interior and exterior excavations.

\section{Terms}

A full discussion of various aspects of manufacture techniques of bottle and other container glass is beyond the scope of this report. However, in order to describe and discuss the diagnostic glass pieces, a few terms are defined.

\section{"Black" glass}

As the quotation marks imply, "black" glass is not really black. When held to a light, the color-achieved by adding iron slag to the glass-is a very dark green. Until the mid-nineteenth century, black glass was preferred, apparently because wine bottlers had

Table 2. Glass Fragments Recovered During the Project

\begin{tabular}{|c|c|c|c|c|c|c|c|c|c|c|c|c|c|c|c|c|c|}
\hline \multirow{2}{*}{ Area } & \multicolumn{2}{|c|}{ Clear } & \multicolumn{2}{|c|}{ Green } & \multicolumn{2}{|c|}{ Brown } & \multicolumn{2}{|c|}{ Aqua } & \multicolumn{2}{|c|}{ Blue } & \multicolumn{2}{|c|}{ White } & \multicolumn{2}{|c|}{ "Black" } & \multicolumn{2}{|c|}{ Other } & \multirow{2}{*}{$\begin{array}{c}\text { Total } \\
\mathbf{N}\end{array}$} \\
\hline & $\mathrm{N}$ & $\%$ & $\mathrm{~N}$ & $\%$ & $\mathrm{~N}$ & $\%$ & $\mathrm{~N}$ & $\%$ & $\mathrm{~N}$ & $\%$ & $\mathrm{~N}$ & $\%$ & $\mathrm{~N}$ & $\%$ & $\mathrm{~N}$ & $\%$ & \\
\hline Interior & 162 & 36.0 & 130 & 28.9 & 107 & 23.8 & 36 & 8.0 & 0 & 0.0 & 0 & 0.0 & 15 & 3.3 & 0 & 0.0 & 450 \\
\hline Exterior & 119 & 43.0 & 78 & 28.2 & 35 & 12.6 & 25 & 9.0 & 1 & 0.4 & 1 & 0.4 & 16 & 5.8 & 2 & .7 & 277 \\
\hline Total & 281 & & 208 & & 142 & & 61 & & 1 & & 1 & & 31 & & 2 & & 727 \\
\hline
\end{tabular}


discovered that wine preserved better in the dark glass (Munsey 1970:37). Black glass went out of fashion after about 1860 , and is seldom seen in historic site components dating after about 1870 (Kendrick 1967:22). Black glass is the most resistant of all glass to decomposition (see Weathering, below). It is routinely found to have little or no signs of weathering.

\section{Clear glass}

The natural color of glass is various shades of aqua or palle amber, due to the varying amounts of iron found in almost all sand used in manufacture. Several different chemicals can be added to a glass to make it clear. This was often done for decorative glassware and for mirror glass. In general, however, clear glass was not routinely used for bottles until about 1880 , when the practice of preserving food in glass containers became popular because people wanted to see the color of the foods they were buying (Munsey 1970:55). At this time the use of manganese to remove the color from glass was perfected. This technique was relatively cheap, and clear glass was used extensively thereafter (Munsey 1970:55).

\section{Cut glass}

Cut glass is decorated by cutting various shapes and patterns in the vessel wall. A small copper or stone wheel is used to cut the designs, which is then polished. The practice was well developed by the mid-eighteenth century, but was expensive (Utterback 1963:37). Because of the cost, cut glass containers were usually intended for the dining table (Utterback 1963:34).

\section{Etching}

Etching is a process in which hydrofluoric acid is applied to the glass. The glass surface is covered with non-reactive material, often wax, the area to be etched is cut out, and the acid applied. The reaction causes the glass to become translucent, or "frosted." Etching is a relatively inexpensive decorative technique.
Finish

This term refers to the last stage of bottle making, when the lip is shaped and the bottle removed from the pontil (if used). Finish used as a noun refers to the specific shape the lip is given, which, by about 1870 was becoming standardized. This was the result of improvements in finishing tools and finishing techniques, spurred by the need for more precisely made bottle tops. The precision was necessary for use of closures other than corks (Baugher-Perlin 1982:268-269).

\section{Free-blown}

Glass containers blown without a mold, using only the skill of the craftsman to shape the final product are termed free-blown (Baugher-Perlin 1982:262). Freeblown glass was time consuming and required a master craftsman to do the work. By the end of the eighteenth century, most commercial glass works were using the mold-blown technique (Munsey 1970:38).

\section{Kickup}

The name for an indentation in the bottom of a bottle. This can range from a slight depression to the deep kickups, sometimes several inches deep, commonly seen in wine bottles.

\section{Laid-on Ring}

Also called an "applied lip," this technique is used to finish a mold-blown bottle. A ring of molten glass is applied around the top of the bottle and shaped with a finishing tool (Munsey 1970:32). This technique was used on larger bottles by the eighteenth century and for smaller bottles by the beginning of the nineteenth, and was abandoned with the invention of the bottlemaking machine in 1903 (Munsey 1970:33). Laid-on rings are usually readily identified, both by the inspection of the ring itself and, more reliably, by the fading away of mold marks near the lip. These have been smoothed away when the ring was added to the bottle and the finishing tool applied (Lorraine 1968:40).

\section{Machine-blown}

In the late-nineteenth century, additional mechanized methods of blowing glass were developed (Lorraine 
1968:42), but it was not until 1903 that Michael Owen introduced the fully automatic bottle-making machine in his plant in Ohio (Munsey 1970:33). This machine revolutionized glass making, eliminating the need for skilled workers and making glass very cheap to produce (Gessner, quoted by Munsey 1970:33). The advantages for glassworks owners were obvious. Less than 15 years later, in 1917,90 percent of all bottles manufactured in the United States were machineblown. By 1926, less than two percent of bottles were still being made by hand (Miller and Pacey 1985:40). Machine-made bottles are recognized by the mold seams that go all the way to the top, seams that circle the top of the lip (except beverage bottles, which are more carefully fire polished after molding), and often, especially in older examples, by suction cut-off marks and/or valve marks on the bottom of the bottle (Munsey 1970:41). The suction cut off marks are slightly roughened areas made when the molten glass is sucked into the mold. The valve marks are small circle marks caused by contact with the plunger which pushes the completed bottle out of the mold.

\section{Mold-blown}

In this technique the glass is blown, either by a glassmaker or a machine, into a mold. Various kinds of molds can be used. The oldest, probably invented before Christ, is the dip mold, which was used to shape the lower part of a bottle only (Munsey 1970:38). Use of hinged molds, which could be used to shape bottom, shoulder, and sometimes even the lip, had became widespread by about 1810 (Lorraine 1968:38). All molds, especially hinged molds, leave characteristic seam marks which can be used to identify the type.

\section{Pontil}

A pontil is a metal rod attached to the bottom of the bottle to hold it while the lip is finished (BaugherPerlin 1982:266-267). The pontil left marks on the bottom of the bottle which were usually not polished or ground completely away. The use of the pontil was largely discontinued after about 1860 , due to the invention of the snap case.
Pressed glass

Pressing, a less expensive technique than cutting, was used primarily for decorative bowls and tableware. The machine used for pressing glass was invented in 1827 (Lorraine 1968:38). From them until 1850, patterns on this type of glass had stippled backgrounds, while later patterns did not (Lorraine 1968:36).

\section{Snap case}

The snap case was invented in 1857 to allow a bottle maker to hold the bottle by the bottom while finishing the lip (Baugher-Perlin 1982:267). The snap case was a rod with a set of curved pieces at the end which could be closed around the bottom of the bottle. Bottles made with a snap case do not have pontil marks on the bottom, but do occasionally have slight impressions near the bottom caused by the pressure of the tool on the still-plastic glass (Baugher-Perlin 1982:267).

\section{Turn-mold}

The term refers to a technique rather than a specific mold. The turn mold was smeared with a paste before the glass was blown into it, and the bottle was twisted before removal. This resulted in a highly polished surface which often had small grooves or scratches running horizontally due to tiny imperfections in the mold. This method, used between about 1880 and 1910 (Munsey 1970:40), did not allow for lettering on the surface, so was used largely for wine bottles.

\section{Weathering}

When glass is buried, it comes into long-term contact with water in the soil. Over time, the soda and lime components in the glass leach out, leaving only the silica (Munsey 1970:51). This forms sheets on the surface of the glass, which, depending on the chemical composition of the glass and the length of time it remains buried, can be a whitish dust, a thin translucent white or iridescent film, or a thick, opaque covering. This film is called patination. It may flake off easily or adhere stubbornly to the glass. A different process causes "water etching," which appears as a series of roughly parallel lines swirling across the surface of the glass. Under the microscope, many, sometime hundreds, of these ridges of various 
heights and widths. The lines are thin deposits of minerals left behind as standing water on the glass evaporated. Water etching is an indication that the glass was exposed on the ground surface. A third kind of weathering is caused by the chemical reaction to ultraviolet radiation of either manganese or selenium in the glass.

\section{Exterior Excavations}

Forty-four pieces of glass were recovered from the exterior excavations which could provide some information other than color. They are listed described below, by area.

\section{Area B}

1) A fragment of an aqua bottle lip (Figure 60a). It cannot be determined if the glass was mold-blown, but the ring has definitely been laid-on. The finish is commonly seen on medicine bottles. There is considerable patination on the surface. The greatest likelihood is that this bottle once contained a patent medicine. In 1810 , there were about 100 "patent" or "proprietary" medicines being sold in the United States (Munsey 1970:66), but by 1906 , there were more than 50,000 (Young 1961:205). These "medicines" were advertised as cures for all kinds of problems, from ill-defined "lassitude" or "anxiety" to cancer, epilepsy, heart disease, and even
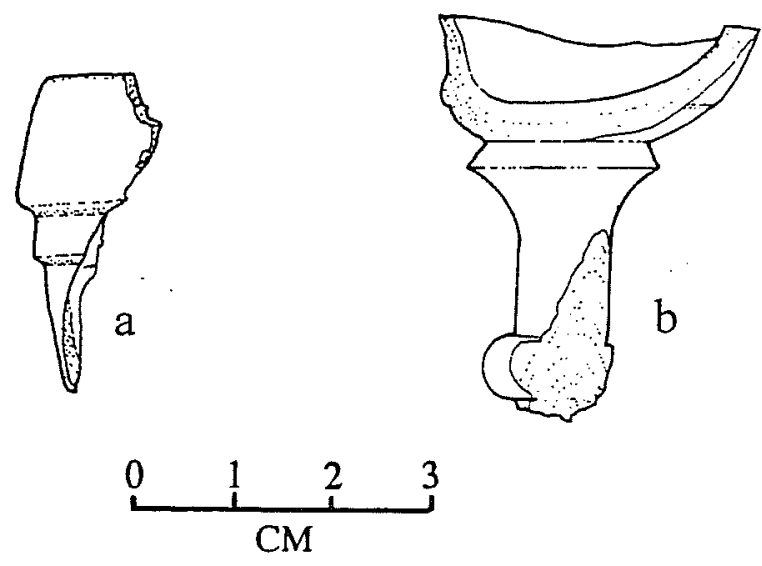

Figure 60. Glass from Area B. a. aqua bottle lip, with "medicine" finish; b. fragment of a wine glass stem. alcoholism. In 1905-1906 a free-lance writer named Samuel H. Adams, writing for Collier's magazine, wrote a series of exposés on this industry. He showed that these medicines were often nothing more than medicine-flavored alcohol, sometimes as high as 60 proof (Young 1961:220). Not all claims for these medicines were false. The dose of cocaine in some undoubtedly did cure lassitude, and anxiety probably yielded to the opium that was a common ingredient in many others (Young 1961:221). The scandal resulting from Adams' articles seriously damaged the patent medicine industry. The articles also helped in the passage of the Food and Drug act of 1907, which forced patent medicine manufacturers to change their contents and their advertising, though it did not necessarily drive them out of business altogether (Young 1961:226-244).

2) A fragment of what appears to be a moldblown flask. Only part of the shoulder and a portion of the front remain. The glass is very clear, with no sign of patination. On the front are the letters ". . . ker" and a small fragment of a design. There is no way to determine if this was blown by a machine.

3) A small fragment of a large bottle or jar. The fragment is brown and mold-blown, probably in a machine. A decorative border of vertical parallel lines enclosed in horizontal lines is embossed at the base. There is no patination on the glass.

4) A fragment of the stem, probably from a wine glass (Figure 60b). The clear vessel was blown in a mold. There is some wateretching, and slight patination.

Area C

1) A fragment of an aqua bottle shoulder. The bottle was made in a mold, but it is not possible to determine if it was machine or hand blown. The letters "LARG. . ." are embossed on the shoulder. The fragment is heavily patinated and slightly water etched.

2) Two fragments, which mend, of a probable flask. The glass is brown and the letters 
"ONE PIN ..." are embossed near the top. This is probably a pint whiskey bottle. Slight patination is present.

3) A very small fragment of a bottle. The glass is clear, and part of an embossed design is present. A bottle in the comparative collection at CAR with the identical design reads "James Clavin/Druggist/114 W. Commerce/Cor. Navarro" (Figure 61). Clavin started his business in 1871 (Woolford 1963:150).

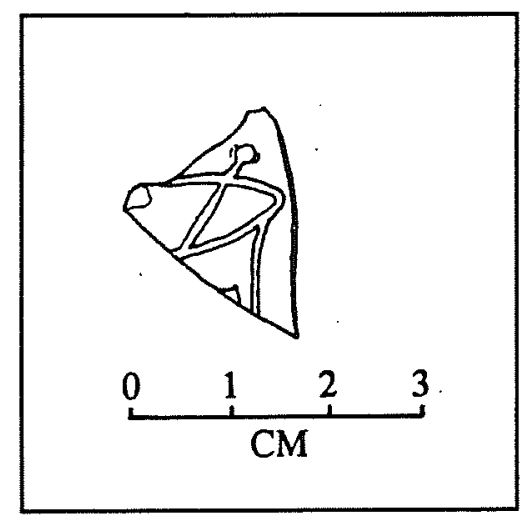

Figure 61. A bottle fragment with a mortar-and-pestle design.

4) A fragment of a bottle, consisting of the lip, neck, and part of the shoulder of a bottle with a whiskey finish. The bottle is clear glass and machine-blown with slight patination. It dates to post-1903.

5) A champagne bottle, complete except for the top of the kickup (Figure 62). The bottle is green glass, has a laid-on ring, and was made in a turn mold. It dates between 1880 and 1910 (Munsey 1970:40). Most of the adhesive which once held the metallic paper cover on the bottle top is still extant. The bottle is very heavily patinated, with an opaque gold-colored coating which adheres firmly to the bottle. In the places where the patination is gone, the bottle surface is pitted and rough.

6) An almost complete 10-sided bottle in four pieces (Figure 63). The bottle is clear glass and mold blown, with a laid-on lip in a medicine finish. It dates between 1880 and 1903. One panel is embossed with the words
"SANTAL de MIDY." Santal is another word for sandalwood. Small bottles containing slivers of sandalwood were un-corked as air fresheners. The bottle is slightly patinated.

7) Two fragments, which mend, of a clear brown bottle bottom, with a decorative pattern embossed around the edges of the front panel (Figure 64a). Not enough of the bottle remains to determine if it was machine made. There is a partial mark on the bottom: “. . . 23/65-6." which appears to have been formed in a plate mold. Barely visible patination is present.

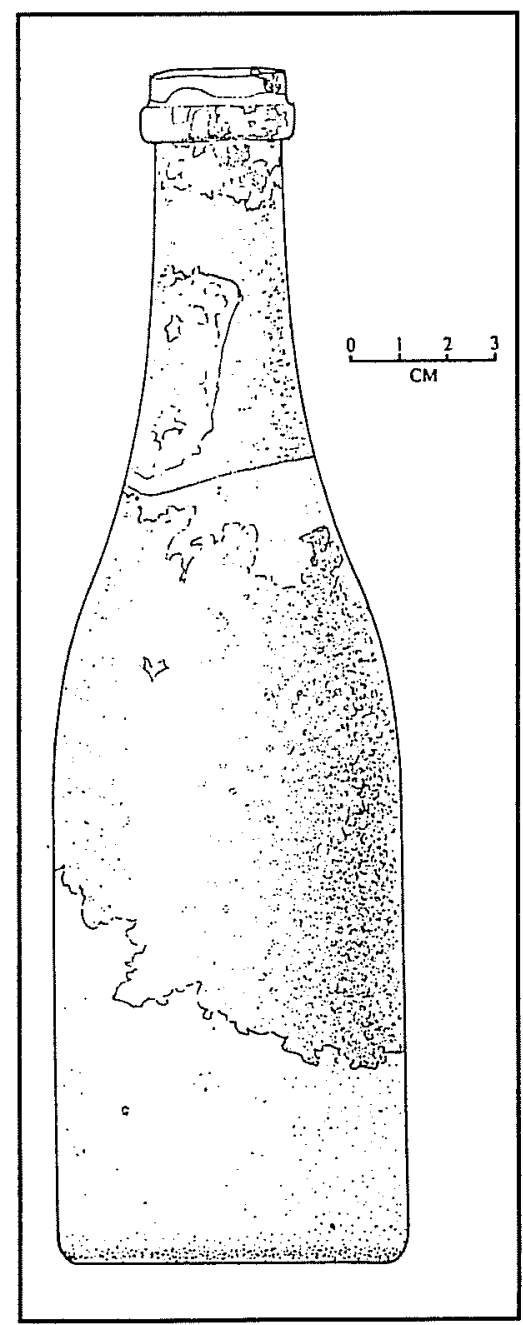

Figure 62. Nineteenth-century champagne bottle. 


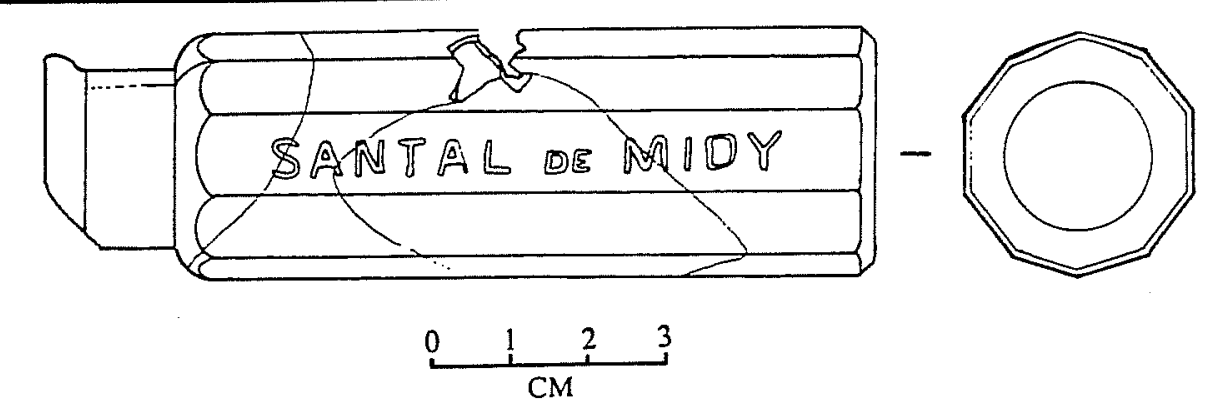

Figure 63. Clear "Santal de Midy" bottle.

8) A fragment of a small bottle, including the lip, neck, and part of the shoulder (Figure 64b). The glass is clear, with a rectangular shape, and a scalloped design just above the turn of the shoulder. The bottle was moldblown, including the lower ring of the lip, but the upper ring was applied. This is indicated by the fact that the mold seam on the lower ring of the lip is almost but not entirely smoothed away by the finishing process, and there is no mold seam on the upper ring of the lip. The lip has a medicine finish. The manufacturing technique suggests a date between 1880 and 1903. The bottle shows slight patination.

9) A small fragment etched with a star.

10) A fragment of a round bottle (Figure 64c). The glass is brown, and the bottle was made in a post-bottom plate mold. There is a slight depression near the bottom, probably from the snap case. The plate mold embossed the letters "SB\&GCo" on the bottom. This is the maker's mark of the Streator Bottle and Glass Company, in Streator, Illinois. The mark dates between 1881 and 1905 (Toulouse 1971:461). The bottle is slightly patinated.

11) A fragment of a clear bottle lip. The piece is too fragmentary to be sure, but it appears to be a laid-on lip. The finish is for a medicine bottle.

12) Two fragments, which mend, of a thick bottle base. The glass is black and contains a fairly large number of bubbles. The bottle appears to have been free-blown, though too little of it remains to be certain. It has only a small kickup with an apparent pontil mark.
This bottle was almost certainly made before 1860 , and probably before 1800 . The surface is slightly pitted, but shows no patination.

13) The bottom of a small rectangular bottle. The glass is clear, and the bottle was made in a cup mold, probably on a machine. There is a light patination and the slight grooves of water etching on the surface.

14) The bottom of a flask-shaped bottle. The glass is clear, and the bottle was probably machine-made. Considerable water etching and slight patination are seen on the surface.

15) A fragment of a rectangular bottle, including a small part of the base (Figure 64d). The glass is aqua, and the bottle was mold-blown, though whether by machine or by hand is not determined. At the bottom of the bottle the letters “. . . OSTON" are molded. This probably refers to the city of Boston, as it was common to include the name of the city of manufacture of the contents on embossed bottles, especially patent medicines (Lorraine 1968:40). The glass is heavily patinated and the surface is deeply pitted.

16) Fragment of a round bottle with a partial embossed mark "WATE . . ." (Figure 64e). The glass is clear, very thick, and was moldblown, but there is too little remaining to determine if it was hand or machine blown. This is probably part of a soda water bottle. Mineral waters were bottled in America as early as 1767 , and by 1850 about 7.2 million bottles were made to supply a single mineral water bottling plant (Munsey 1970:102). Soda water bottles required thicker glass to avoid explosions (Munsey 1970:103). 

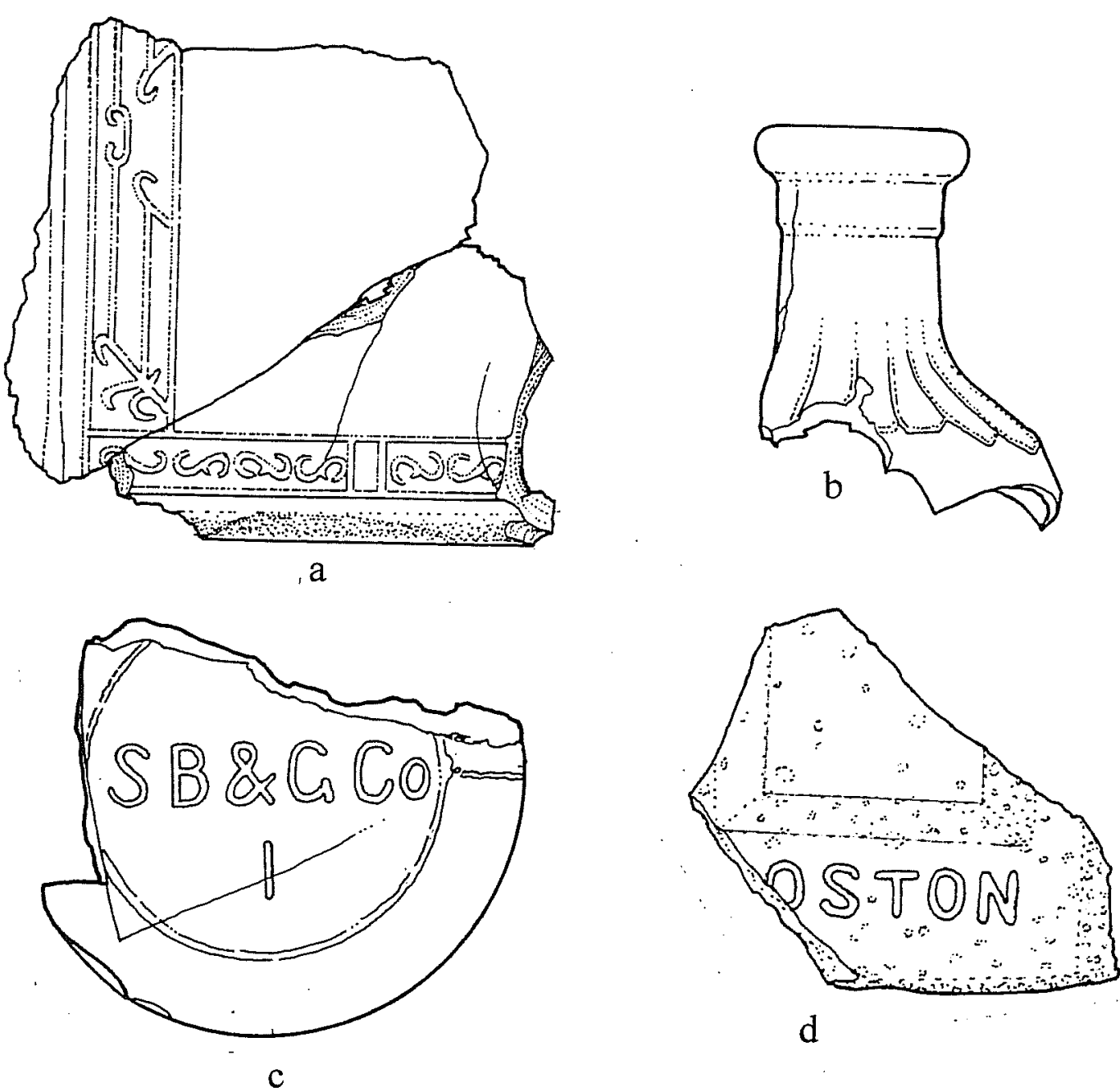

d
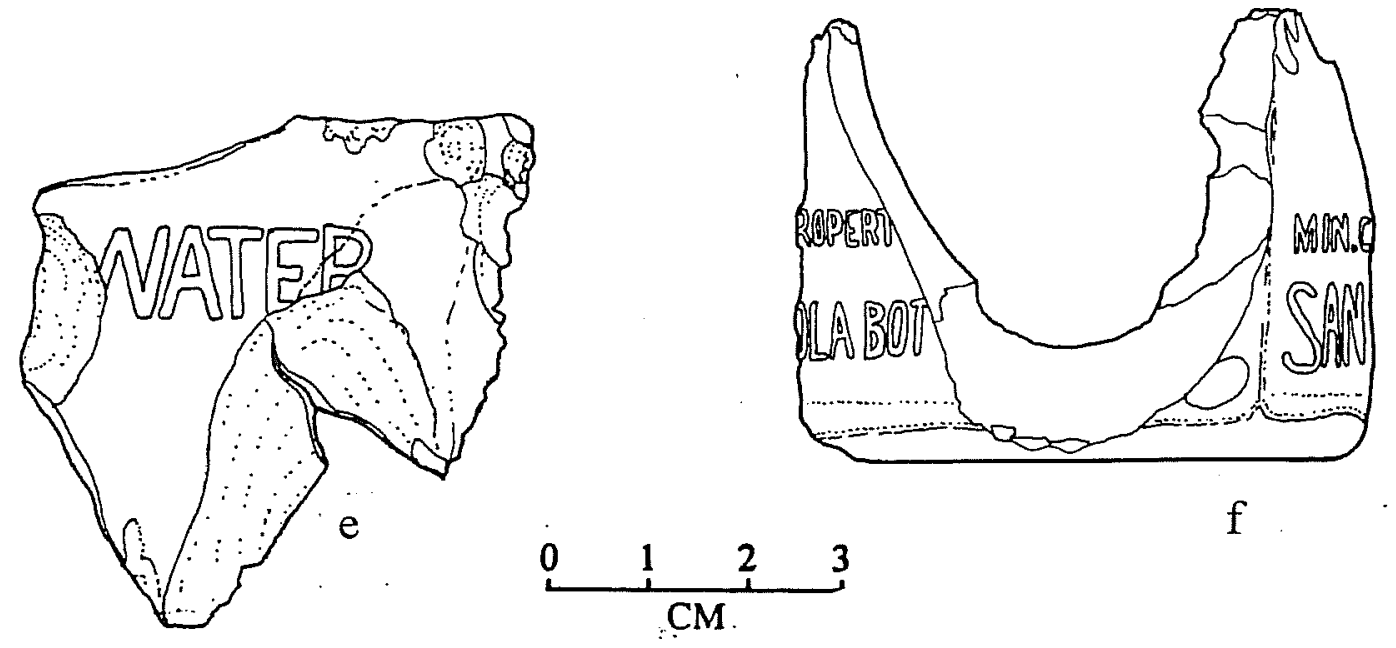

Figure 64. Diagnostic glass from the exterior excavation. a. brown glass bottle with embossed design; b. clear glass bottle fragment with molded shoulder; c. bottle bottom made by the Streator glass company; $d$. molded aqua bottle fragment; e. fragment of a soda water bottle; $f$. base of a Coca-Cola bottle manufactured in San Antonio before 1915. 
Carbonated waters, naturally occurring at first, were being bottled by 1810 , and during the 1830 s manufactured carbonated water began to be bottled in increasing amounts (Munsey 1970:103). Flavorings were first added about 1839 (Munsey 1970:103).

17) A fragment of a bottle neck. The glass is aqua and fairly thick. The bottle was blown in a mold and has a laid-on lip. The finish is a shape seen primarily on mineral water bottles (see Sellari and Sellari 1975:188). The bottle was manufactured in the nineteenth century.

18) A fragment from the body of black glass bottle. The glass is very poor quality, with numerous bubbles, not only inside the glass but also breaking out on the surface, inside and out. The letters ". . LA" are embossed on the bottle. The fragment is too small to gain any more information from it. It was probably manufactured before 1860 . The quality of the glass is unusually poor. There is no sign of patination on the surface.

19) A fragment of a rectangular bottle, with a small part of the bottom and base. The glass is very clear, and part of a molded design is visible. The bottle was made in a cup mold, but whether machine or hand-blown is not determined. The letters "FU . . ." are embossed near the bottom and the letters ". . . S A" in quotation marks are embossed on the bottom. The quality of the glass and the complete lack of weathering suggests recent manufacture.

20) A fragment of the bottom of a round Coca-Cola bottle (Figure 64f). The bottle is aqua and was blown in a cup mold, almost certainly by machine. In one area near the bottom, the letters ". . . ROPERT/. . . OLA BOT . . ." are embossed. On the other side the letters "MIN. . . .SSAN . .." are embossed. On the bottom ". . C C" is embossed. This bottle is from the San Antonio Coca-Cola Bottling Company. A 1969 article in the San Antonio Light newspaper stated that the San Antonio Coca-Cola Bottling Company was started in 1903 (San Antonio Light, 27 September
1969); however, the city directories do not list this company until 1910. In any case the shape of the bottle indicates a date before 1915, when the standard Coke bottle shape still in use today was adopted (Munsey 1970:106).

21) Two fragments of a clear pressed glass goblet. The design is simple ridges, and the thin glass indicates a fairly inexpensive item.

22) Three fragments of a cut glass goblet (the largest piece is shown in Figure 65a). The clear glass was first molded and then cut. The glass is thick and heavy, indicating a fairly expensive item.

23) A fragment of a pressed glass bowl (Figure 65b). The bowl would have been small and probably used as a relish, pickle, or candy dish.

24) Two fragments of a small, pressed glass lid, approximately $7.5 \mathrm{~cm}$ (3 inches) in diameter. This could have been from either a candy dish or a cosmetics container, though the latter is more likely.

Monitored Area East of the South Transept

1) A fragment of the base of a piece of stemmed glassware. The glass is clear, with only slight patination.

2) A wine bottle bottom. The glass is green, with a deep kickup. The bottle appears to have been free-blown, suggesting it is no more recent than the early nineteenth century.

3) A fragment from a bottle (Figure 66). The glass is dark amber, and is embossed with the letters "SANFOR . . . ONE . . ." This is probably from a Sanford ink bottle, similar to those described by Sellari and Sellari (1975:371). If so, it dates to the turn of the century.

Test Pits Along the South Wall of Apse

1) Three fragments, which mend, of the neck and shoulders of a green wine bottle (Figure 67a). The bottle was free-blown, with a pulled neck and a laid-on ring, which was finished by hand. This bottle is early nineteenth century or earlier. Patination and water etching are visible on the surface. 

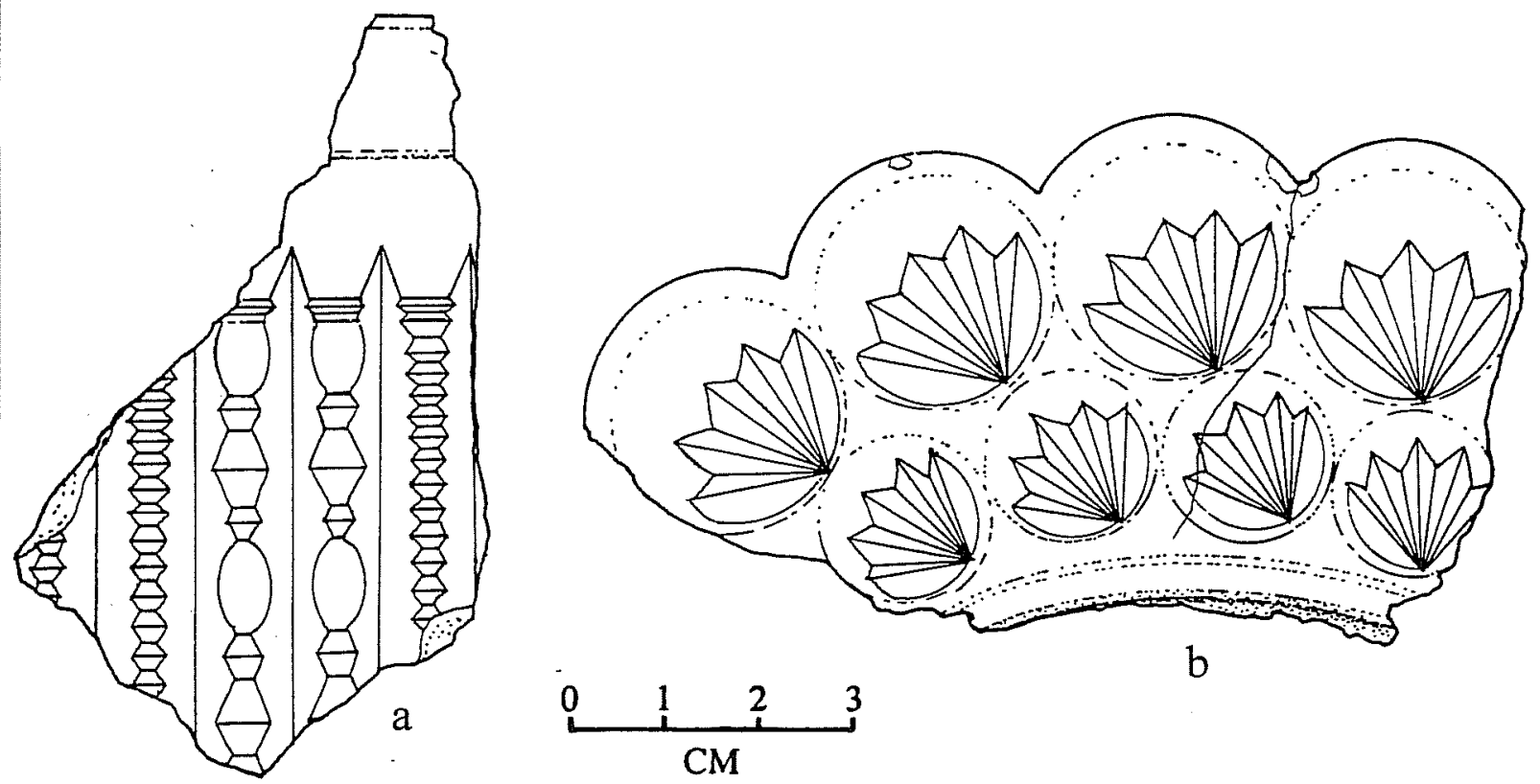

Figure 65. Drawings of cut and pressed glass from Area $C$. a. fragment of a cut glass goblet; $b$. fragment of pressed glass bowl.

2) Three fragments, which mend, of the bottom of a green wine bottle, probably the same as the one shown in Figure 67a. The bottle is freeblown, with a tall kickup and a bare iron pontil mark (Figure 67b).

3) A fragment of a bottle neck. The glass is black, with a laid-on ring finished by hand. There is some sign that the neck was pulled, but it is too fragmentary to be sure. The bottle dates before 1870 , and probably to the early nineteenth century.

4) Two pieces, which mend, of a bottle neck and part of the shoulders (Figure 67c). The glass is black and the neck is formed in a style called a "ladies leg" (Sellari and Sellari 1975:43). The neck a number of tools marks and the distinctive "stretch" marks of a pulled neck. There is an unevenly placed laid-on ring, finished with a lipping tool. The finish is a style most often seen in whiskey bottles. The date on this bottle is probably early to mid-nineteenth century.

5) A free-blown bottle bottom, with a shallow kickup (Figure 67d). The glass exactly matches the bottle top shown in Figure 67c. A solid bar pontil mark is seen on the bottom.

\section{Interior Excavations}

Fifteen diagnostic glass fragments were recovered from the interior excavations. They are listed by provenience.

$100.5 \mathrm{~N} / 97 \mathrm{E}$

1) The lip of a brown bottle, with the copper wire intended to hold the cork in place still attached

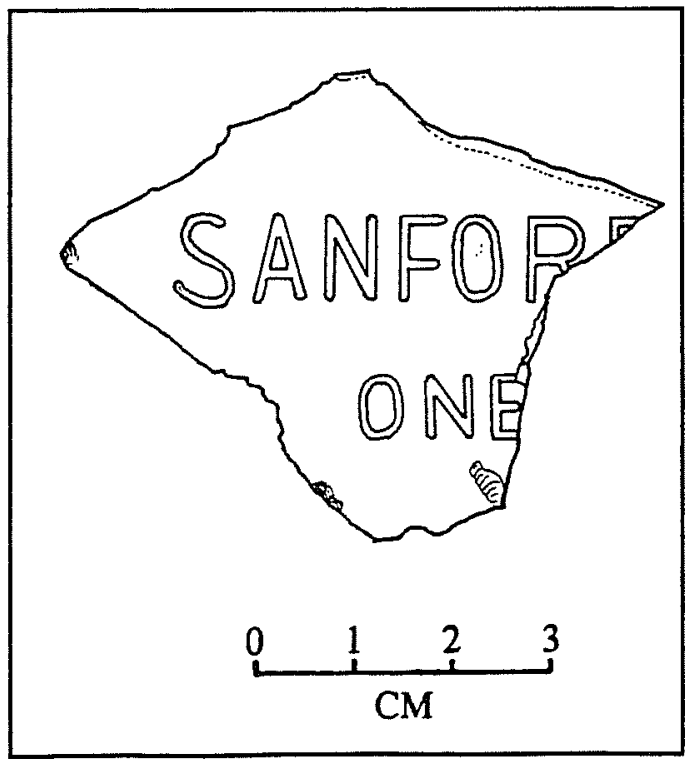

Figure 66. Sanford ink bottle fragment. 


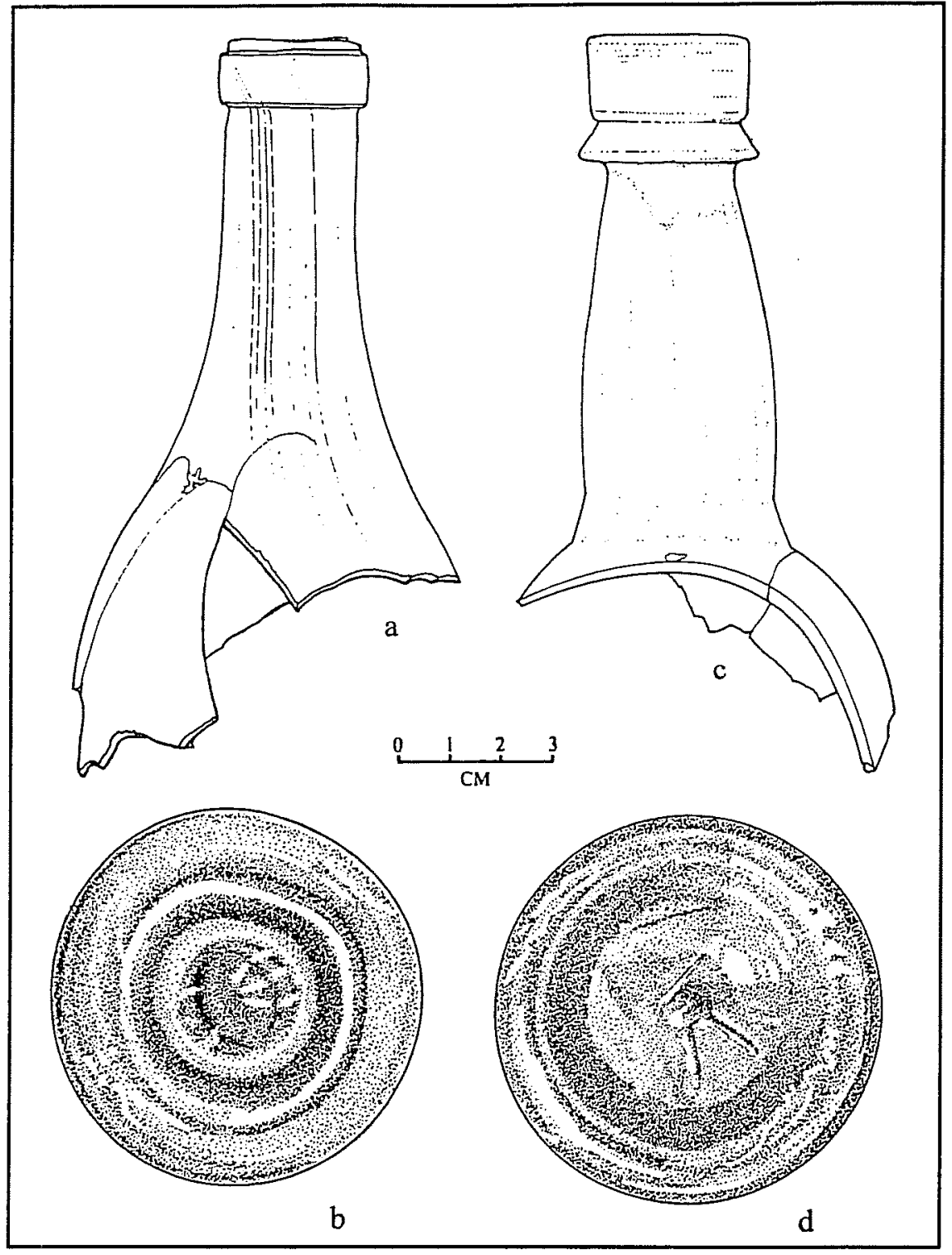

Figure 67. Early nineteenth-century bottles from monitored excavations. a. free blown green glass bottle neck, b. green glass bottle bottom, showing uneven, handmade kickup, c. black glass, "ladies leg" bottle top, d. black glass bottle bottom with pontil mark.

(Figure 68). The neck is pulled and has a laid-on ring finished with a lipping tool. It is probably free-blown. The lip shape is common on whiskey bottles. There is some cement/mortar adhering to the bottle and to the wire.

\section{$100.5 \mathrm{~N} / 98 \mathrm{E}$}

1) A fragment of the base of a black bottle, probably a wine bottle. The unevenness of part of the kickup and a very slight flaring at the base makes it likely that this bottle was free blown. It is probably early nineteenth century or earlier in date. There is no patination on the surface.

\section{N/93E}

1) A fragment of a bottle lip. The glass is brown and the lip was applied and finished by hand. The shape of the finish cannot be determined with certainty, but it appears to be a wine bottle. Slight patination is present.

\section{$101 \mathrm{~N} / 95 \mathrm{E}$}

1) A fragment of a decorative glass ribbon (Figure 69a) which would have been attached to the exterior of some container. This decoration was definitely attached by hand, suggesting that the container was either old (probably pre-1840) or handmade after the use of molds became common. The latter indicates the

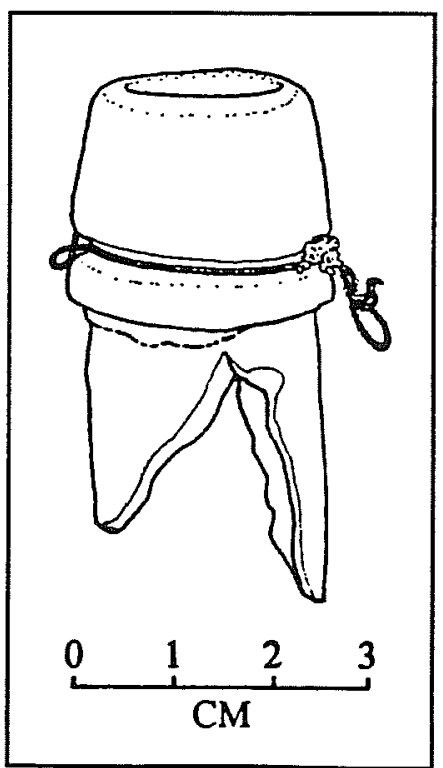

Figure 68. Brown glass bottle top with copper wire still attached. 

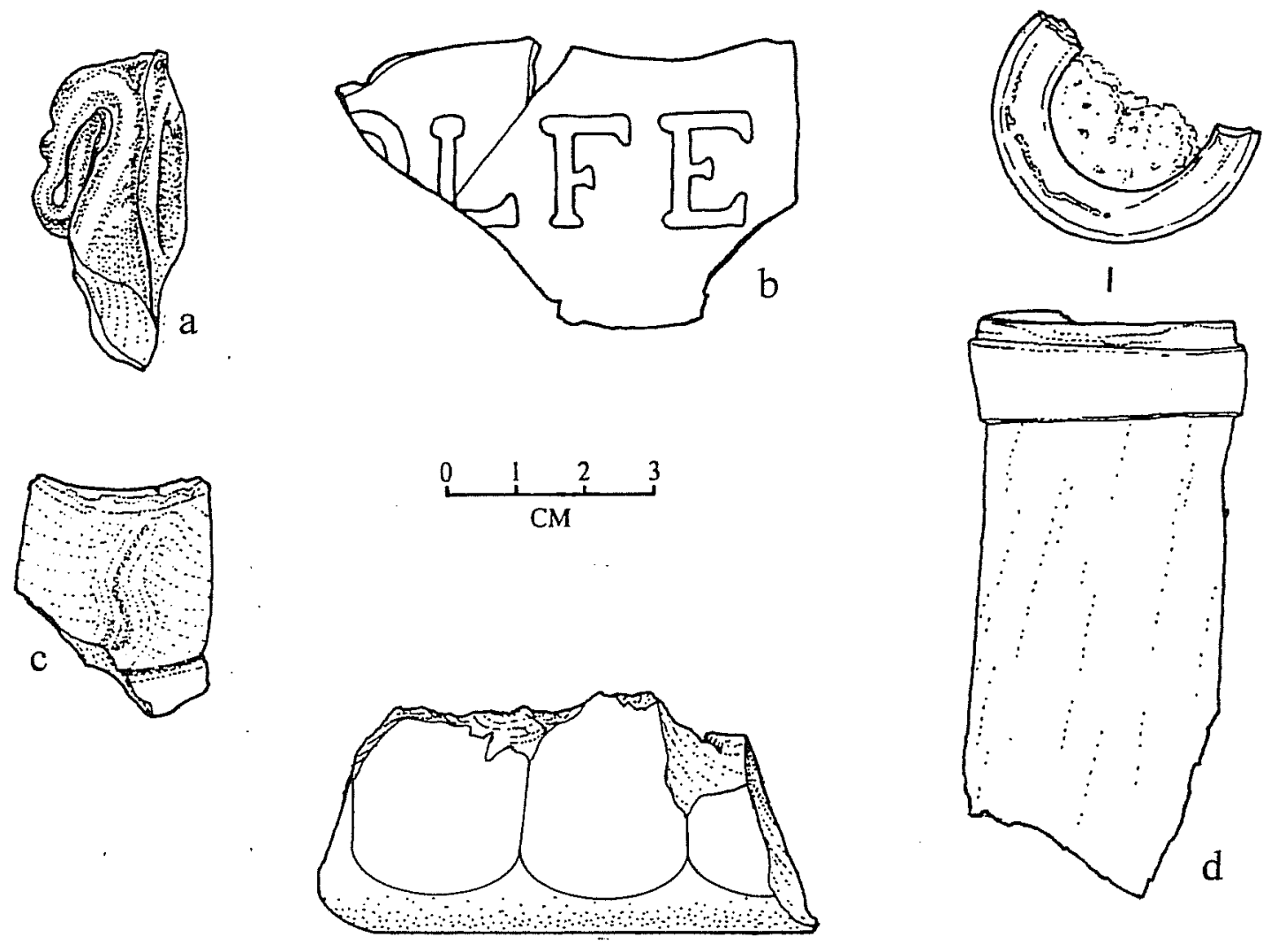

e

Figure 69. Diagnostic glass from the interior excavations. a. decorative glass ribbon; b. brown glass fragment with embossed lettering; c. black glass bottle lip; d. two views of a green glass free-blown bottle neck filled with cement/mortar, the upper view shows fire-polished lip and cement/mortar, the lower view shows "stretch marks" of a pulled bottle neck; e. thick glass container bottom.

piece was intended for either the dining or the dressing table and was quite expensive.

\section{$101 \mathrm{~N} / 97 \mathrm{E}$}

1) Most of the bottom of a square-shaped bottle made in a cup-mold. The glass is light brown and heavily patinated. There is no sign of a pontil mark, so it probably dates after 1870 . There is no way to determine if it was machine or hand blown.

2) Two fragments, which mend, of the same color and thickness as the side panels of the bottle above. The letters ". . . OLFE' ..." are embossed on the fragments (Figure 69b). These fragments and the bottle bottom above may be the remains of a bottle of Wolfe's Schnapps. Sellari and Sellari (1975:130) illustrate a similar bottle. Unfortunately, they do not include a date. The glass is heavily patinated.

\section{$101 \mathrm{~N} / 98 \mathrm{E}$}

1) A fragment of a bottle lip (Figure 69c). The glass is black. The finish appears to have had a wire ring at its base, though it is too fragmentary to be certain. The lip is handshaped and almost certainly free blown. The edge of the lip still shows signs of having been broken off the blow pipe and fire polished.

2) A fragment of a wine bottle neck (Figure 69d). The glass is green and the bottle appears to have been free blown. The slightly swirling lines which indicate a pulled neck are particularly visible. The edge of the lip has been broken off and fire polished. It has a laid-on ring which was applied and finished 
with poor craftsmanship. This bottle fragment was probably made in the early nineteenth century or earlier. A large amount of cement/mortar is found in the neck.

3) A small fragment of a bottle lip. The glass is black, and the lip was laid-on and finished with a lipping tool. The piece is too fragmentary to identify the shape of the finish.

\section{$101 \mathrm{~N} / 100 \mathrm{E}$}

1) A fragment of a bottle lip. The glass is green, and the ring was laid on and apparently finished by hand. This suggests the piece was made before 1840 (Munsey 1970:32). Cement/mortar adheres to the glass.

\section{N/93E}

1) A fragment of a very thick container bottom (Figure 69e). The thickness of the bottom and the relative thinness of the walls suggest it was not a bottle. The container was round at the bottom, but the glass was flattened into a 12-sided polygon. At the upper edges of the fragment there appears to be part of a more complicated pattern, but it is too fragmentary to identify. There is a pontil mark on the bottom and no visible mold marks, so it may have been free-blown. Though less than half of the bottom is extant, one would expect a hinge mold of any kind to leave visible mold marks. If it was mold blown, it may have been blown into a dip mold, which would leave no seams on the bottom. The container probably dates to the early nineteenth century or earlier.

\section{$102 \mathrm{~N} / 94 \mathrm{E}$}

1) A fragment of a bottle body. The glass is brown, with iridescent patination. The letters “. . . B[or D] A ..." are embossed.
$102 \mathrm{~N} / 95 \mathrm{E}$

1) A bottle seal (Figure 70). The glass is clear and has an iridescent patination. A seal is a lump of glass pressed with a design while still plastic (Toulouse 1971:9). Bottle seals allowed glass makers to produce standardized bottles and then personalize small numbers for individual buyers. Seals are usually attached above the shoulder. The design on the recovered seal is a German doubleheaded eagle, surrounded by the words "IMPT [Maltese Cross] ABASCHION ZARA". The mark was not identified, but shoulder seals were usually attached to liquor or wine bottles.

\section{$102 \mathrm{~N} / 100 \mathrm{E}$}

1) A fragment of a bottle body. The glass is brown and heavily patinated. The letters "... E \& . . ." are embossed on the fragment.

\section{Discussion}

Because of the difference in recovery techniques inside and outside, the numbers and ratios of various glass colors and bottle types cannot be reliably compared; however, a few observations can be made. Of the fragments from the exterior excavations for which manufacturing technique can be determined, three (14.3 percent) date after the invention of Owens's bottle-making machine in 1903. Of the 12 bottle fragments from the early nineteenth century, 10 (83.3 percent) were recovered from the caliche/clay level east of the south transept (in Area $\mathrm{B}$ and the monitored excavations). This is consistent with the ceramics from this area. In the interior excavations, the eight datable fragments were all pre1903 , and most were probably from the earlier part of the nineteenth century. 


\section{Other Kitchen Items}

Very few other kitchen items were recovered. One pewter screw cap was recovered in one of the test units south of the south wall in Area C (Figure 71a). It has a faint design of fine concentric circles on the top, and had a thick layer of white calcite coating, which was removed during laboratory processing. Screw caps were invented as early as the seventeenth century, and became common as closure for small food bottles (especially sauces and extracts) after about 1860 (Munsey 1970:145; Sellari and Sellari 1975:302). Examples of similar lids on Durkee sauce bottles from the late 1800s are shown in Sellari and Sellari (1975:303).
DRT took over administration of the chapel in 1905 and evidently, since the crown cap is surely the most ubiquitous of all post-1900 artifacts, they were successful at preventing litter around the Shrine. A single poptop tongue was also recovered in Area C.

\section{Household Items}

Very few furniture and other household items were recovered (Table 3). The two furniture items were both drawer handles. The handle in Figure $71 \mathrm{~b}$ is from a small drawer, while the handle shown in Figure 71c is about dresser drawer size.

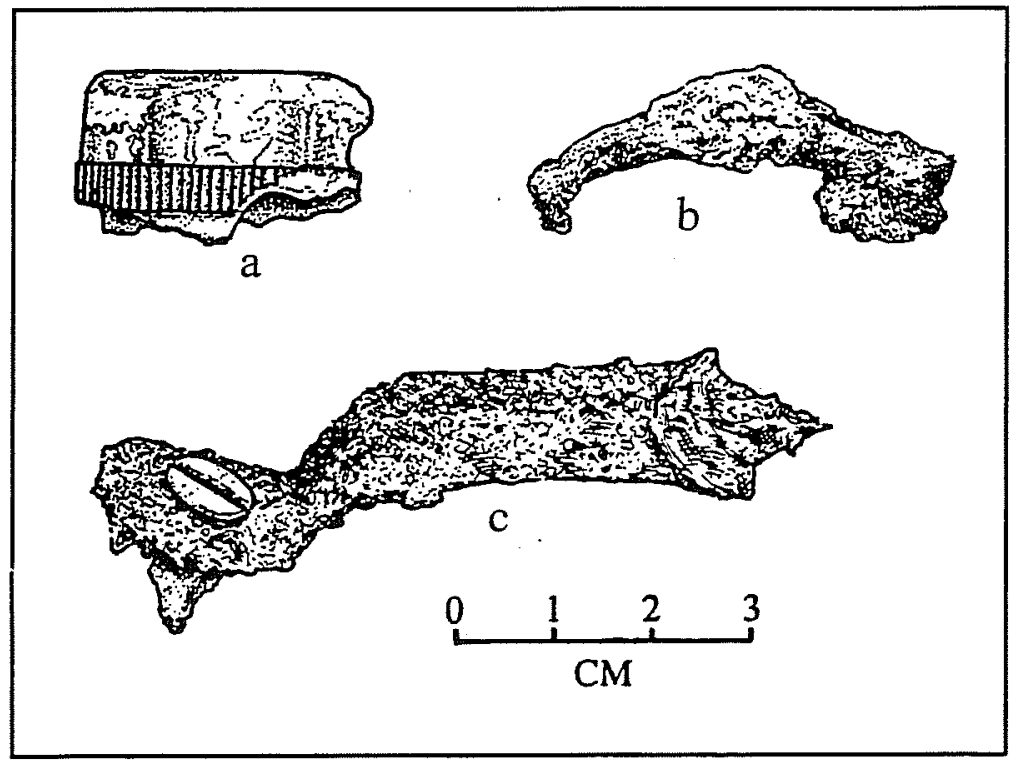

Figure 71. Household items. a. pewter screwcap. b. small drawer pull, c. large drawer pull.

A small lead piece embossed with a scroll design was recovered in Area C. It may have been part of a lead label and/or seal.

Interestingly only one crown cap was recovered. Although some may have been missed in the shoveled part of Areas B and C, none was recovered in any of the hand-dug units either. This is probably a reflection of the fact that, though crown caps were patented in 1891, they did not become really popular until after the spread of the Owen machine because they required a uniform lip shape (Munsey 1971:105). The

\section{Clothing/Personal Items}

\section{Clothing}

Clothing is usually too perishable to last long in most archaeological contexts. Buttons and other fasteners are an exception. One strap fastener about the size for overalls was found in Area B (Figure 72). Buttons have been made from almost any material both shapeable and hard enough to stand up to the wear. Five buttons of four different materials were recovered during the project. They are listed below according to provenience. 
Table 3. Household Items

\begin{tabular}{|c|c|c|c|c|}
\hline \multicolumn{2}{|r|}{ Provenience } & $\begin{array}{c}\text { Furniture } \\
\text { Parts }\end{array}$ & $\begin{array}{l}\text { Lamp Glass } \\
\text { Fragments }\end{array}$ & $\begin{array}{l}\text { Flowerpot } \\
\text { Fragments }\end{array}$ \\
\hline \multirow{3}{*}{ 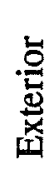 } & Area B & 0 & 0 & 2 \\
\hline & Area C & 2 & 1 & 2 \\
\hline & Test pits south of apse & & 1 & 0 \\
\hline \multirow{3}{*}{ 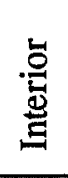 } & $101 \mathrm{~N} / 97 \mathrm{E}$ & 0 & 6 & 2 \\
\hline & $101 \mathrm{~N} / 98 \mathrm{E}$ & 0 & 2 & 0 \\
\hline & Totals & 2 & $\mathbf{1 0}$ & 6 \\
\hline
\end{tabular}

Area B

1) A highly fragmented shell button, approximately $1.0 \mathrm{~cm}$ in diameter with a shallow well and four holes. This is a common shirt or dress button, probably made from marine shell. Shell, pearl, or motherof-pearl buttons can be made from either marine or freshwater shell, though the former are generally more richly iridescent (Albert and Kent 1949:58). The fragmentation makes it difficult to be sure, but the holes appear to be unevenly spaced, which implies that the button was hand cut. Machine-cut shell buttons replaced hand-cut starting about 1850 (Albert and Kent 1949:59).

2) About half of a bone button and associated gut thread (Figure 73a). Bone has been used for buttons since before Christ, and was still in use until replaced by synthetics beginning just before World War I (Pool 1987:289). Since the eighteenth century, bone buttons were most popular for underwear (Albert and Kent 1949:25). This button is $1.5 \mathrm{~cm}$ in

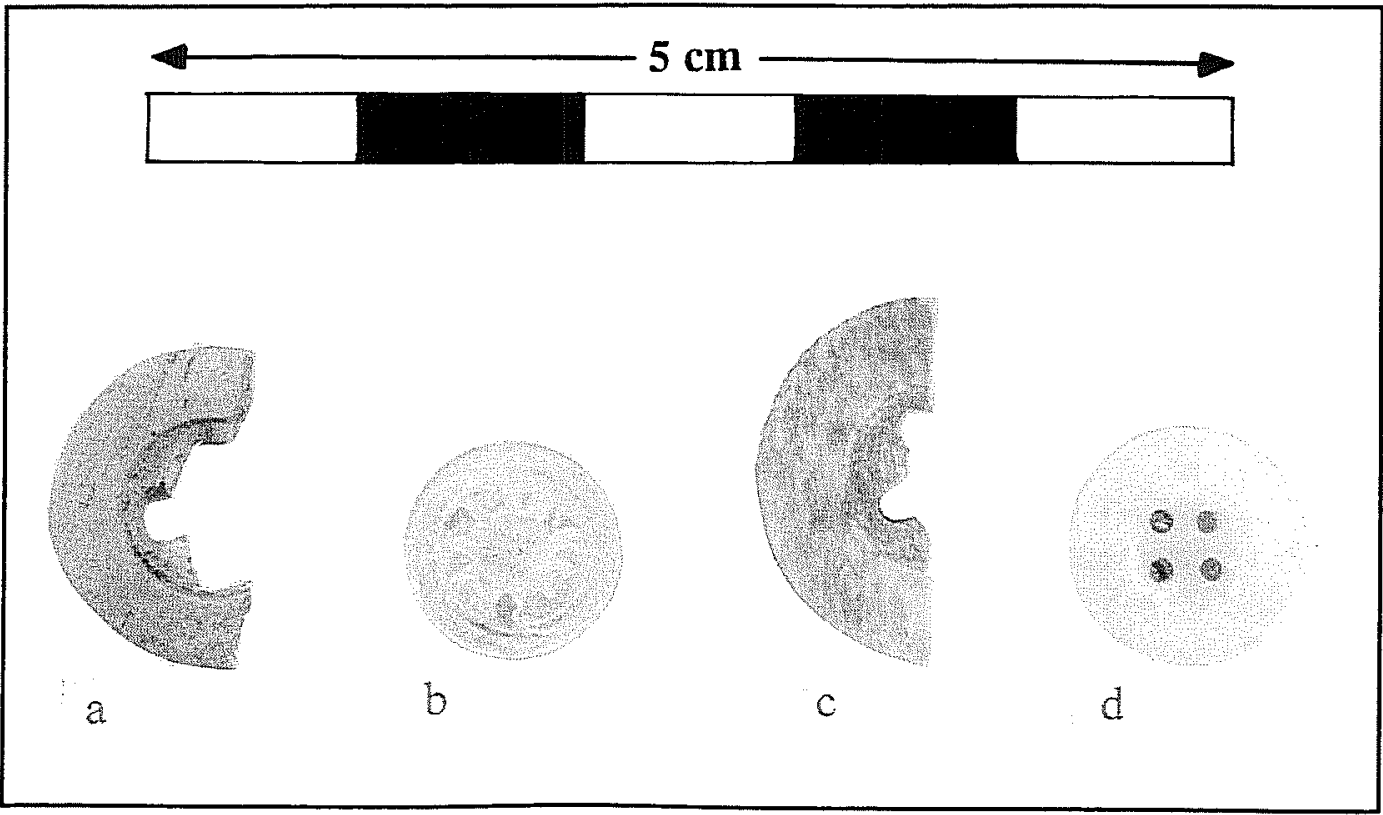

Figure 73. Buttons. a. broken bone button, with gut thread, b. decorated shell button, c. fragment of a vegetable ivory button, d. ceramic button. 
diameter and has a well and four holes. The thread, still partially attached to the button, appeared at first to be nylon or other synthetic, but examination under the microscope revealed that it is dried gut, probably rodent.

\section{$101 \mathrm{~N} / 95 \mathrm{E}$}

1) A shell button, $1.0 \mathrm{~cm}(.4 \mathrm{inch})$ in diameter, with four holes (Figure 73c). The face is decorated with a thin incised circle surrounding short incised lines which radiate out from the deep well. Under the microscope these are clearly hand-made. The unevenness of the hole spacing also suggests they were not machine drilled. This button, therefore, likely dates before 1850 .

\section{$101 \mathrm{~N} / 99 \mathrm{E}$}

1) A fragment of a vegetable ivory button (Figure 73c). Vegetable ivory is the name given to items carved from the South American corozo nut. The first vegetable ivory buttons manufactured in Europe appeared in 1862 (Albert and Kent 1949:72). Buttons of vegetable ivory were easier and cheaper to make than bone buttons, so were very popular for less expensive clothing. Although during World War I it was discovered that rats in the trenches were partial to vegetable ivory buttons-leading to a decline in their use on uniforms (Whittemore 1992:19)-they continued to be popular until after World War II and the coming of modern plastics (Albert and Kent 1949:74). This button is $1.7 \mathrm{~cm}$ in diameter and is broken approximately in half. The remains of a well and four holes, which appear machine cut, are visible.

\section{$102 \mathrm{~N} / 100 \mathrm{E}$}

1) A ceramic button (Figure 73d). Ceramic buttons were handmade, elaborate, and quite expensive until 1840 when a machine method was first used for the job and inexpensive ceramic (actually a type of porcelain) buttons became commonplace (Epstein and Safro 1991:74). By 1850 a wide variety of sizes was common, and remained so until about 1910 (Albert and Kent 1949:35). To manufacture them, a fine powder of kaolin clay, either dry or dampened, was pressed into molds and then fired (Albert and Kent 1949:35). This method usually leaves a few tiny pits or a rough area on the bottom of the button, making the differentiation between ceramic and glass buttons easier. Ceramic buttons have sometimes been mistaken, even in the archaeological literature (Roberson 1974:46), for milk glass because they are often quite translucent (Pool 1987:281). This button is $1.1 \mathrm{~cm}$ (.5 inch) in diameter, a common size. It has a well and four holes.

All the buttons recovered during the project are probably nineteenth century in origin. The shell buttons are probably from the first half of the nineteenth century, the vegetable ivory and ceramic buttons from the last. The bone button could be from any time in the nineteenth century.

\section{Sewing Items}

The only sewing item recovered was a pair of badly corroded embroidery scissors (Figure 74), found in Area $\mathrm{C}$. The finger hole of one side is broken off and the other is bent into a right angle from the rest of the implement. Overall length would have been about 10 $\mathrm{cm}$ (4 inches).

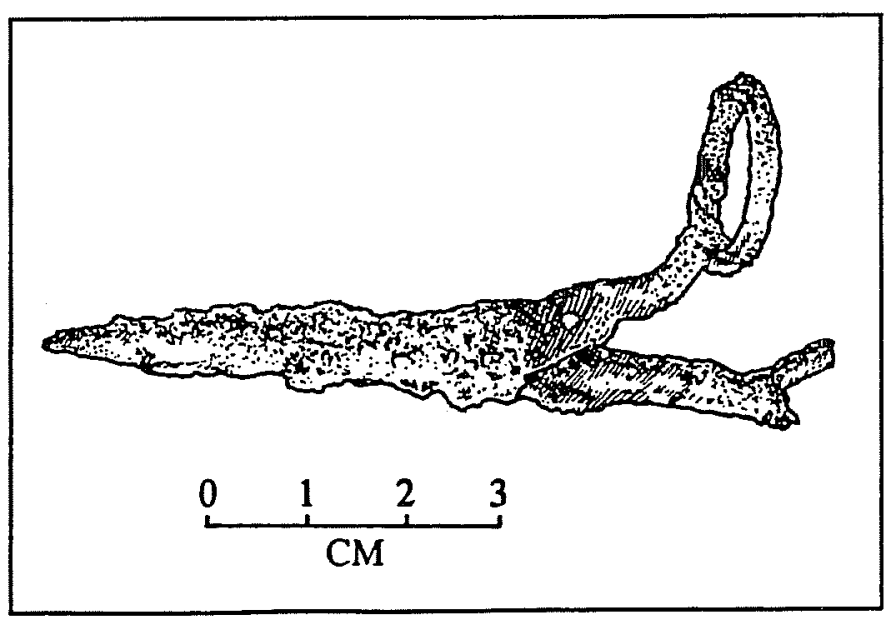

Figure 74. Embroidery scissors. 


\section{Coins}

Five coins were recovered during the project. One U.S. penny dated 1970 was found on the surface, under the gravel in the exterior excavations. Two U.S. pennies with dates of 1969 and 1976 were recovered from the top of the exterior foundation, about 1.5 $\mathrm{m}(5 \mathrm{ft})$ east of the west comer of the south transept. A 1933 U.S. penny was found against the wall of the alcove, in the interior excavations, just under the ground surface.

\section{A silver coin (Figure 75) was} recovered in the fill dirt around the cedar post in the police station foundation (see Figure 28). The
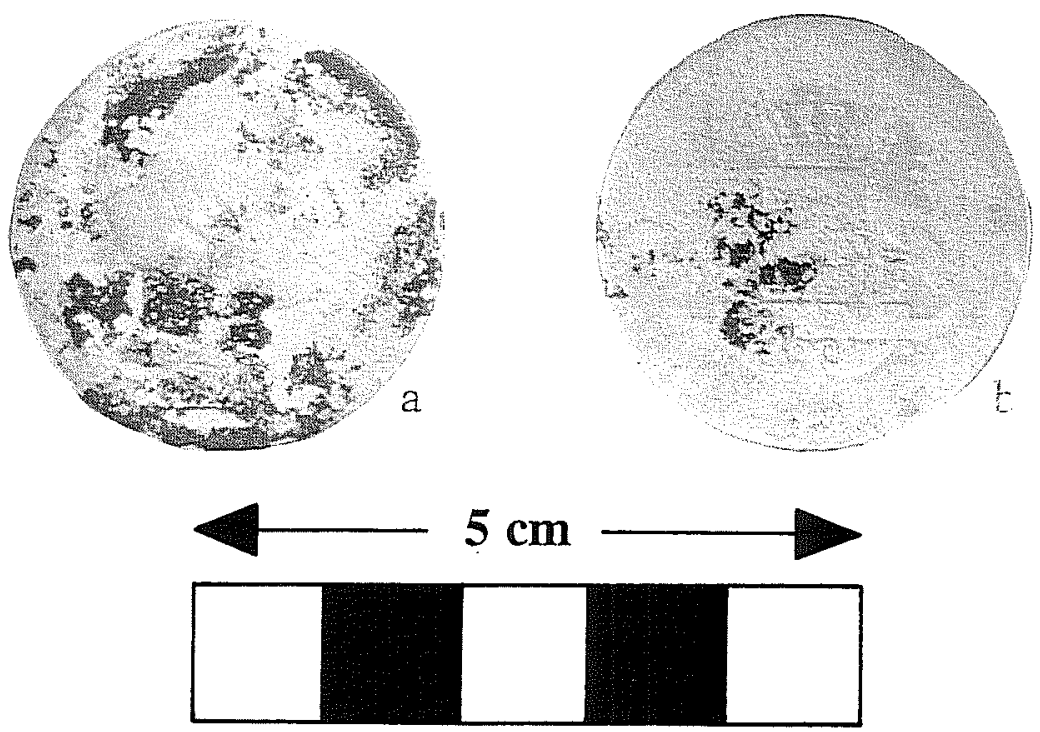

Figure 75. Silver coin recovered in the foundation of the police station. a) obverse; b) reverse.

coin was badly worn and heavily oxidized. After professional cleaning, the coin was identified as German, with a bust of Maxmillan II. The date on the coin has been completely worn away, but this coin was only minted between 1857 and 1864 (Roger Huckabee, personal communication 1995). The coin might have been dropped either during the construction of the police station or when the station was torn down. The degree of wear on the coin suggests it had been in circulation for a long time.

\section{Other Personal Items}

Three ceramic pipe fragments were recovered. Clay pipes are primarily artifacts of the nineteenth century and earlier (Herment 1957:13). After the turn of the century, most pipes were made of less fragile (and less durable) materials.

One pipe fragment was recovered during the monitoring of excavations east of the south transept (Figure 76a). It is a part of the stem just above the bowl. This particular style was made in Point Pleasant, Ohio, by one of a series of four potters who worked on the site from the 1840 s to about 1890 (Sudbury 1979:182).
Two pipe stem fragments were found in $102 \mathrm{~N} / 96 \mathrm{E}$. One fragment has a raised rectangular design (Figure 76b), the other has no design (Figure 76c). Their proximity suggests they may be from the same pipe.

In addition to the three pipe fragments, remnants of a tin can were found in Area C. The can is of an oblong shape commonly associated with tobacco containers.

A fragment of a tooth from a plastic comb was found in Area C. It is an older type of plastic, and may predate World War II. One small piece of mirror glass was also recovered from 101N/94E.

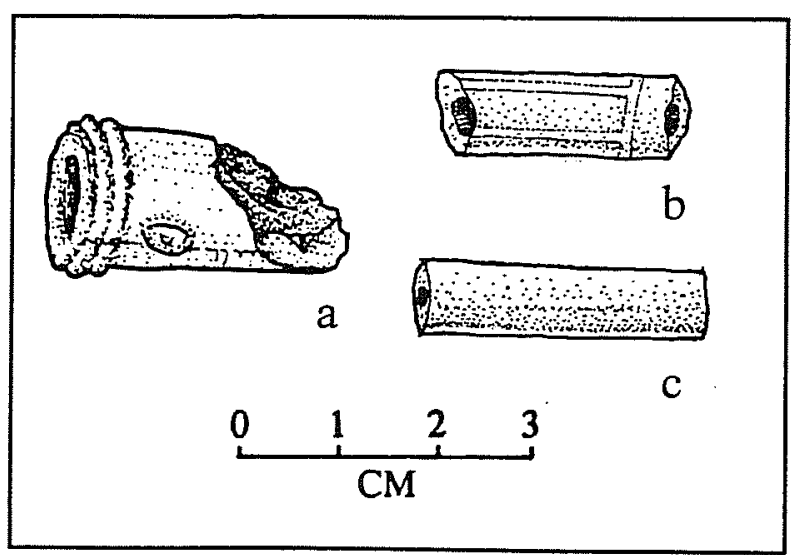

Figure 76. Ceramic pipe fragments. a. pipe fragment made between 1840-1890, b. pipe stem with rectangular decoration, c. undecorated pipe stem. 


\section{Activities}

\section{Toys}

Toys found in historic sites in San Antonio represent, at best, only a fraction of the kinds of toys once used. Until the Industrial Revolution reached San Antonio via the railroad in 1877 , most toys would have been made either of materials that did not survive to be recovered by archaeologists, or of recycled materials not recognizable now as playthings. For instance, a hoop from a wagon hub used by a child as a toy (Abernathy 1989:4) will likely be classified as "wagon parts," not "toy," in a catalog of recovered historic artifacts. It was not until the last few decades of the nineteenth century that commercially made toys-which are generally more identifiable and/or made of more durable materials-became common. Though expensive bisque and porcelain dolls had been made in Europe since the late-eighteenth century, it was not until after the Civil War that the little ceramic "penny babies," so common in the 1880 s and afterwards, were first manufactured (Byfield 1986a:36) and made available to any little girl who lived near a railroad and could find a penny.

Three toys were found during the excavation, all from the exterior excavations. In Area B was a tiny fragment of a small porcelain doll dish, probably a bowl, with a slight ridged design molded on the outer surface. Also in Area B was a fragment from the back of the head of a ceramic doll (Figure 77a). This piece is unusual in two ways. First, it is made from a coarse porcelain not commonly seen in doll manufacture; second, it uses an inexpensive but effective way to color the hair: the hair was molded, then a brown glaze was applied. The glaze settled into the deeper parts of the molded design and appears much darker than on the higher parts of the design, where it is quite thin and lighter in color. The effect is to add highlights to the hair, making it look as if it were carefully handpainted.

The third toy fragment is a fragment of the lower back of a ceramic doll, just above the buttocks and including a small portion of the edge of the hole left for insertion of moveable legs (Figure 77b). This fragment is well-molded, of good quality bisque, with a light pink complexion coat which is partially worn off. Jointed all-ceramic dolls like this would have been considerably more expensive than other kinds of dolls common in the nineteenth and early twentieth centuries. For example, a wholesale toy catalog, dated 1893 (Stirn 1990[1893]:10-11), lists numerous dolls from little two-inch "penny babies," which were molded as a single piece with stiff arms and legs, to china limb dolls, in which ceramic heads and appendages were sewn onto cloth bodies, to allceramic dolls with moveable arms and legs. The listed price for a dozen of these three types was $\$ .07$ for penny babies, $\$ .30$ for small china limb dolls, and $\$ 1.75$ for all-ceramic dolls with moveable legs (Stirn 1990[1893]:10-11). Assuming the retail markup for the latter was the same as for the penny babies, this would mean the all-ceramic doll would have cost $\$ .20$ each retail, or 20 times the cost of the penny baby. The doll fragment shown in Figure $77 \mathrm{~b}$ is from one of these more expensive dolls.

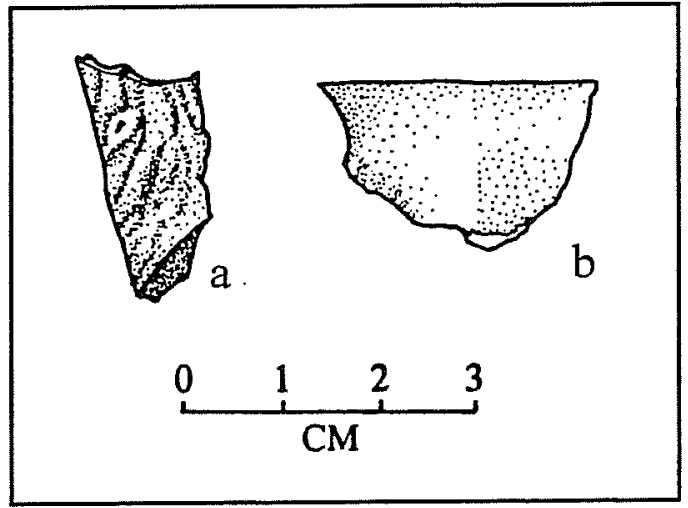

Figure 77. Ceramic doll fragments.

a. fragment of doll's head with molded hair;

b. fragment of doll's back.

\section{Writing Materials}

The only writing materials recovered during the project were three small fragments of slate, all from the interior. They are quite thin, ca. $15 \mathrm{~mm}$ (.6 inch), and polished smooth on both sides, indicating they were intended for a blackboard. Two of them, from units 100.5N/97E and 101N/100E have thin, incised lines cut into them and red paint inside the lines. One has two lines with a one-centimeter space between 
them. There are no lines on the other side of these fragments. The third piece, from $100.5 \mathrm{~N} / 98 \mathrm{E}$, has very similar incised lines, one on each side, but no red paint. The 1895 Montgomery Ward catalog carried an item with the following description: "Hyatt 'Peerless' Noiseless Slate with non-erasable colored lines on one side, produced by a patent process which leaves slate perfectly smooth and even . . . size, $6 \mathrm{x}$ 9 inches" (Montgomery Ward and Co. 1969:119; emphasis in the original). These little wood-framed slates were $\$ 0.12$ each. The lines were intended as guides for children learning to write their letters. The recovered slate fragments probably came from such a product.

\section{Barn/Workshop/Garage}

Very few items recovered were from the Barn/Workshop/Garage category (Table 4). The monitored excavation of the area south of the apse uncovered several metal pieces that appeared to be automobile parts, but as they were not temporally diagnostic they were not collected. The hubcap (Figure 78) is from a
1916-1919 Pontiac with wire wheels (Marcie Branson, personal communication 1995). A Champion spark plug fragment was also recovered (Figure 79).

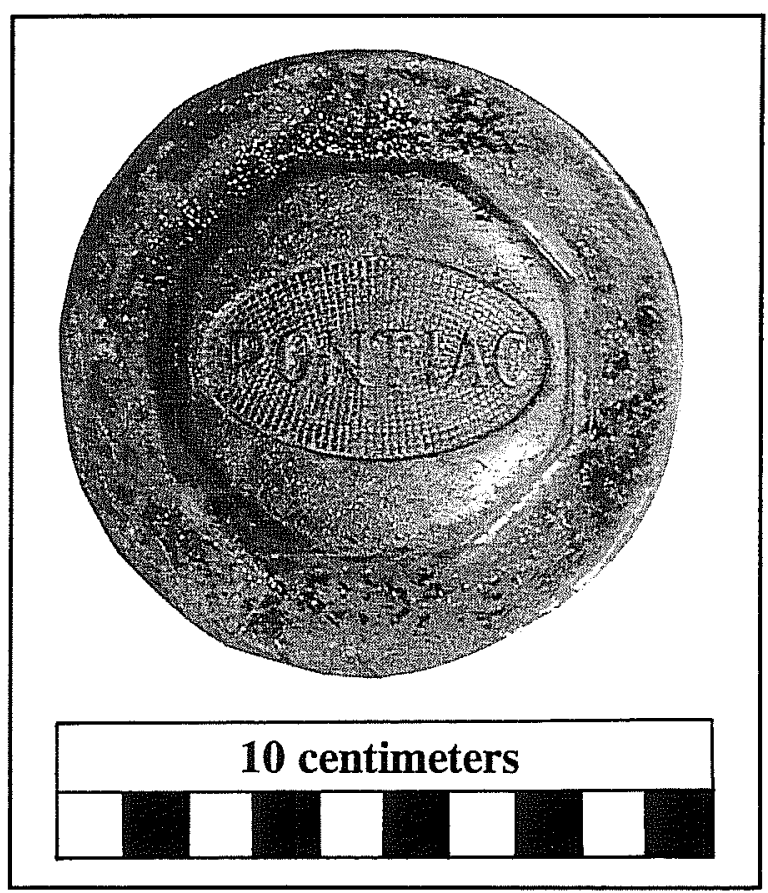

Figure 78. Pontiac hubcap from 1916-1919.

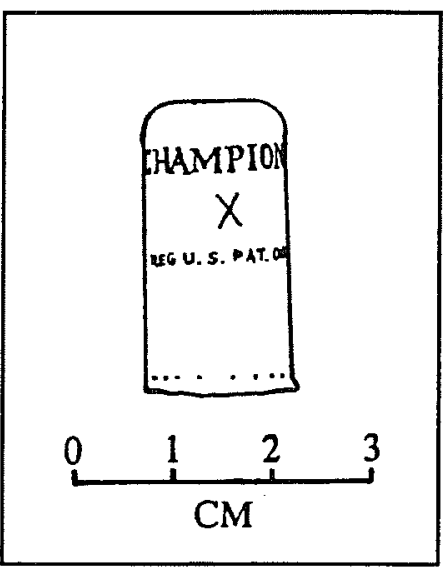

Figure 79. Ceramic spark plug fragment.
Table 4. Artifacts from Barn/Workshop/Garage Category

\begin{tabular}{|c|c|c|c|}
\hline \multicolumn{2}{|r|}{ Provenience } & Item & Count \\
\hline \multirow{4}{*}{ 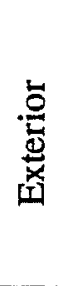 } & Area B & Wire & 5 \\
\hline & \multirow{2}{*}{ Monitored Area } & Spark plug fragment & 1 \\
\hline & & Pontiac hubcap & 1 \\
\hline & Area $\mathrm{C}$ & Wire & 12 \\
\hline \multirow{5}{*}{ } & $101 N / 94 E$ & Wire & 2 \\
\hline & $101 N / 95 E$ & Wagon part (?) & 1 \\
\hline & $101 N / 100 \mathrm{E}$ & Wire & 4 \\
\hline & $102 \mathrm{~N} / 98 \mathrm{E}$ & Iron ring & 1 \\
\hline & $101 N / 99 E$ & Horse tack & 1 \\
\hline & & To & 28 \\
\hline
\end{tabular}




\section{Utilities}

Only three artifacts representing water, sewer, gas, and electrical utilities were recovered, all from the shoveled dirt in Area C. One is a fragment of a carbon rod from an arc lamp. This can be dated after 1881, when the San Antonio Electric Company began operations by installing 10 carbon arc lamps in Alamo Plaza (City Public Service 1976; Hemion 1978). The second artifact is a ceramic base for an electric incandescent light bulb (Figure $80 \mathrm{a})$. The bulb was designed to be pushed into a socket rather than screwed in. Some mortar/cement is seen on the outside of the base. Though the dating of this type of lightbulb is unknown, it was probably quite early. Incandescent lightbulbs were "delicate and inefficient" (Harpur 1982:25) before 1908, when a new process for making tungsten filaments was developed (Harpur 1982:28).

The other utilities artifact is a two-piece ceramic insulator, about $2.6 \mathrm{~cm}$ ( 1 inch) in diameter and $4.2 \mathrm{~cm}$ ( 2 inches) long (Figure 80b). The letters "BULL DOG" and a trademark consisting of a small " $\mathrm{W}$ " inside $a$ " $V$ " are embossed on one end. A wire nail has been pushed through the hole in the middle.

\section{Construction}

A total of 704 items of construction material was collected (Table 5). Nails were by far the most common construction material recovered, comprising 52.8 percent of the total. Window glass was 37.2 percent of the total and the remaining items together were only 9.9 percent of the total.

The nails are of particular interest because the general shape is a marker for the beginning of the twentieth century. There have been three basic methods of manufacturing nails: forged, cut, and wire. Rectangular nails are forged, that is, individually
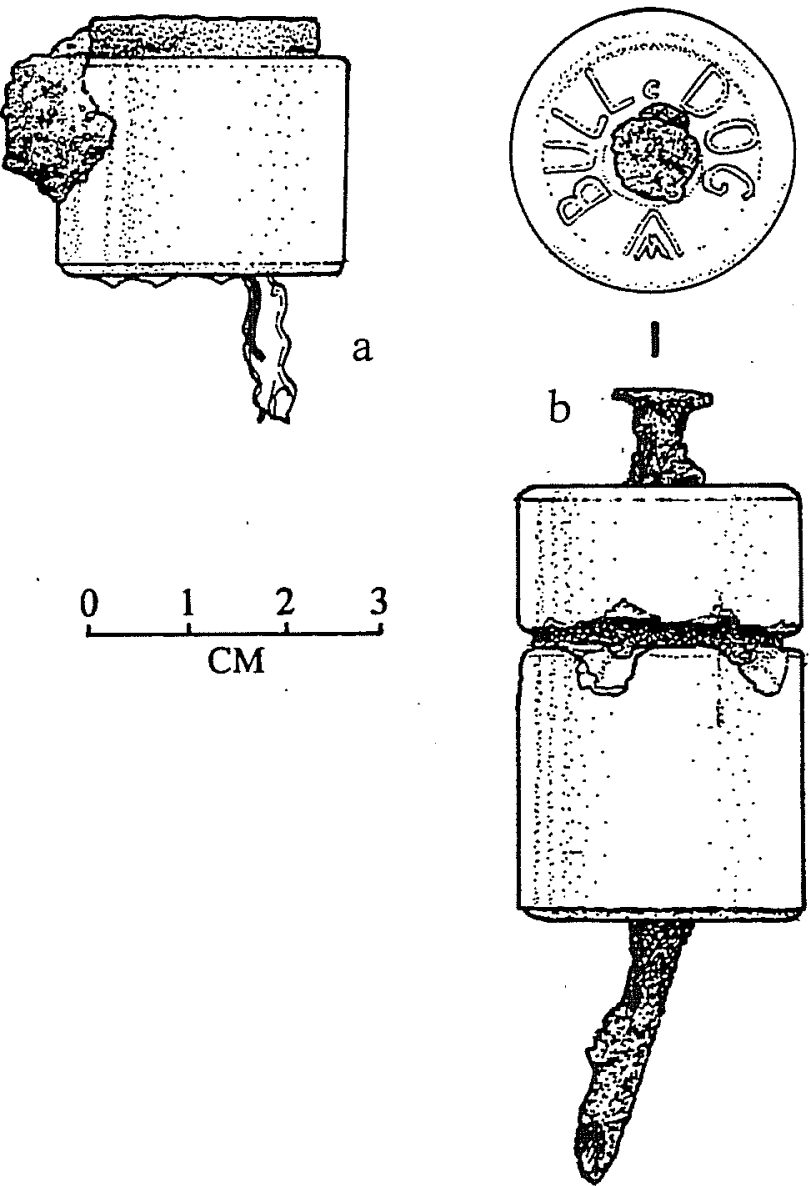

Figure 80. Electrical artifacts. a. ceramic lightbulb socket; b. top and side view of a ceramic insulator.

made on a forge by a blacksmith. Square nails are usually "cut" or "plate" nails (Edgerton 1897:246), that is, cut from a pieces of metal stock and finished by hand. In general, forged nails are older than cut nails. Wire nails are cut from lengths of wire, making them round in cross-section, and finished by machine. When corroded, it is often difficult to differentiate the nail types; therefore, all rectangular and square nails are grouped together in the cut-nail category.

Though the first machine-made wire nails were produced in about 1850 , they did not begin to compete seriously with cut nails until the last decade of the nineteenth century. They constituted 20 percent of the nail industry by 1888 , and 75 percent by 1895 (Edgerton 1897:246). Because of this, wire nails are considered diagnostic of the twentieth century. 
Table 5. Construction Materials from the Project

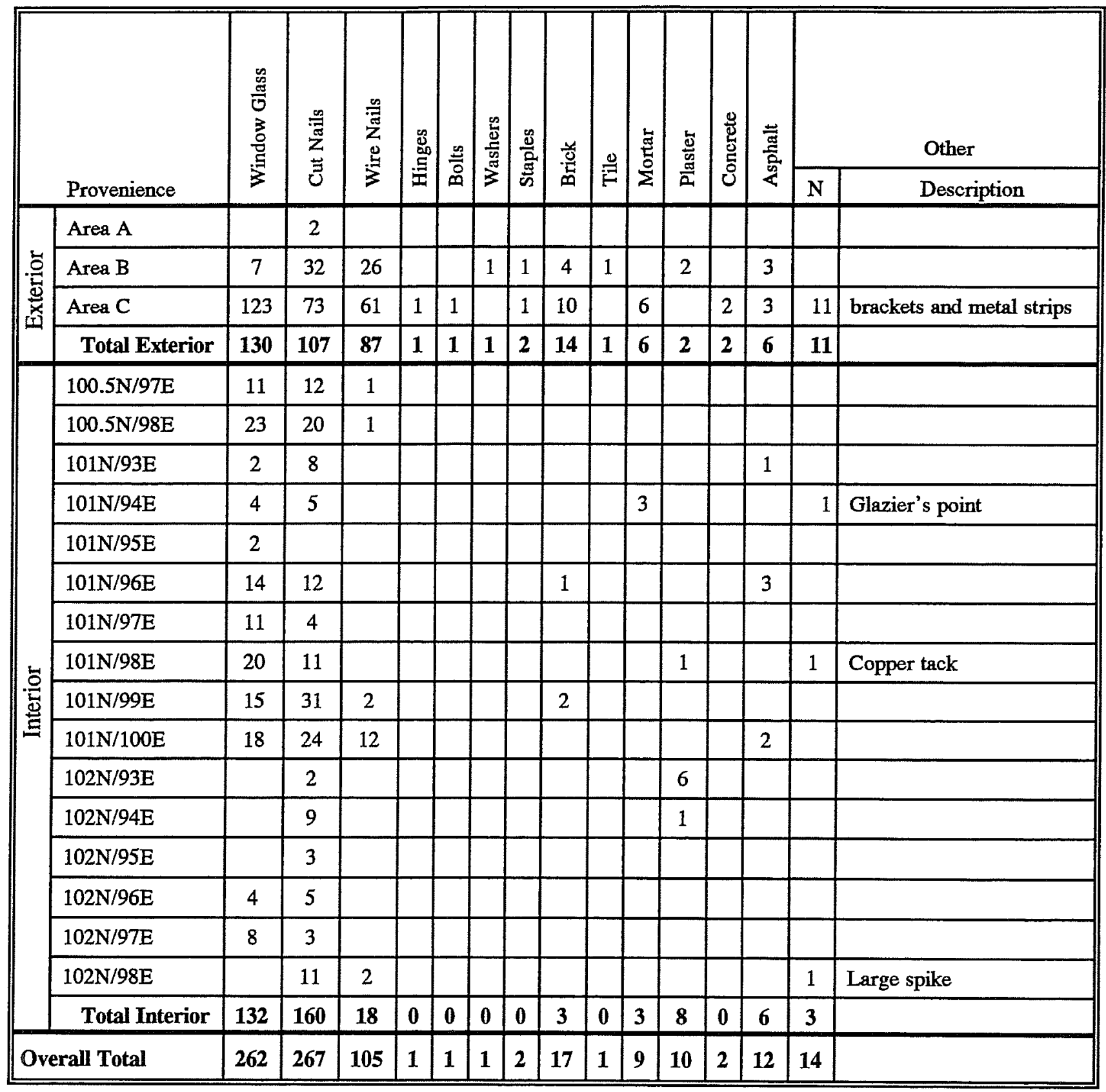

Comparison of cut versus wire nails is made in Table 6. In the exterior excavations, cut nails are only slightly more common than wire. This suggests a somewhat later date for the introduction many of the nails into the area than for most of the other artifacts. Unlike crown caps or plastic, however, nails are the one kind of "trash" that might have accumulated in the area after the DRT took over control of the building in 1904, due to the various renovations and other work which has been done in the area. The framework used to construct the inner arch of the arcade, seen in the background of the photograph in Figure 39, for instance, was almost certainly made with wire nails, some of which could easily have found their way into the fill added to the area.

The interior excavations recovered a much higher percentage of cut nails than wire nails. In fact, the latter were found exclusively in the alcove area, near the walls, where they might have been dropped during 
Table 6. Cut vs. Wire Nails

\begin{tabular}{||l|c|c|c|c|c|}
\hline \multirow{2}{*}{ Excavation Area } & \multicolumn{2}{|c|}{ Cut Nails } & \multicolumn{2}{|c|}{ Wire Nails } & \multirow{2}{*}{ Total Nails } \\
\cline { 2 - 6 } & $\mathbf{N}$ & $\boldsymbol{\%}$ & $\mathbf{N}$ & $\boldsymbol{\%}$ & \\
\hline Exterior & 107 & 55.2 & 87 & 44.9 & $\mathbf{1 9 4}$ \\
\hline Interior & 160 & 90.0 & 18 & 10.11 & $\mathbf{1 7 8}$ \\
\hline
\end{tabular}

renovation of the window before the floor was paved in 1936. The high percentage of cut nails in the interior is consistent with dating of other artifact types.

Very little of the brick found during the excavations was collected. That which was recovered was too fragmentary to identify. However, information is available concerning the bricks used to construct the pavement in Area B in the exterior excavations. This brick paving consisted-with four exceptions-of red brick, many of which had the "D'HANIS" logo stamped on them. The D'Hanis Brick Company began making machine-pressed brick in the town of D'Hanis, some 50 miles west of San Antonio, in 1905 (Hodge and Victor 1983:77). However the molds for these bricks had been purchased from another manufacturer and had the logo "L\&L" on them (San Antonio Express-News, 11 October 1977:1B). The D'Hanis logo was established by 1908 , when the company started making brick for the barracks at Fort Sam Houston (Hodge and Victor 1983:77). The bricks from the pavement do not have the Common Brick Manufacturers Association (CBMA) logo on them, which suggests a date prior to 1920 (Gross and Meissner 1997). Thus these D'Hanis brick were probably produced between 1908 and 1920.

Numerous small pieces of various types of mortar were found during the excavations, but only a few pieces were sampled. One piece, from $101 \mathrm{~N} / 98 \mathrm{E}$ in the interior, was covered on the exterior with whitewash, and the remains of a fairly detailed design in orange paint (Figure 81).

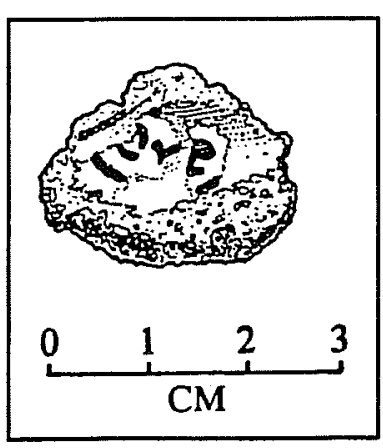

Figure 81. Mortar fragment with whitewash and orange paint.

\section{Lithics}

Sixteen pieces of worked stone were recovered during the project: one utilized flake and 14 pieces of debitage. The lithic materials are listed by provenience in Table 7 . The small amount suggests that very little prehistoric or early Colonial-period strata are included in the disturbed mix in either the exterior or interior excavations.

\section{Discussion}

Results of the artifact analysis are consistent with the findings during the excavation. Most of the artifacts are domestic trash, with nails and window glass being the only other types of artifact found in any great abundance.

Artifacts from exterior excavations confirm the impression left by the stratigraphic profiles. The sediments in Area A were almost sterile, except for sherds of the two lead glazed pots which were also found in Area C. The sediments in Area B were also nearly sterile until the caliche/clay level was reached (about $55 \mathrm{~cm}$ below ground level). Artifacts in the caliche/clay level are consistently early nineteenth century in origin. This level may represent an undisturbed early nineteenth-century stratum in the east of the south transept.

If, as Figure 39 indicates, the ground surface in the 1930s was considerably lower than it is today, the fill above the level of the concrete foundation originated elsewhere. The artifacts 
Table 7. Lithic Materials

\begin{tabular}{|c|c|c|c|c|c|}
\hline & Provenience & Count & Flake Type & Material & Notes \\
\hline \multirow{6}{*}{. } & \multirow{3}{*}{ Area B } & 3 & Secondary & Chert & Debitage \\
\hline & & 1 & Tertiary & Chert & Debitage \\
\hline & & 1 & Secondary & Quartzite & Debitage \\
\hline & \multirow{3}{*}{ Area $\mathrm{C}$} & 1 & Primary & Chert & Debitage \\
\hline & & 6 & Tertiary & Chert & Debitage \\
\hline & & 1 & Secondary & Chert & $\begin{array}{l}\text { Flake with small amount of } \\
\text { use-wear along one edge. }\end{array}$ \\
\hline \multirow{2}{*}{ 总 } & $100.5 \mathrm{~N} / 98 \mathrm{E}$ & 1 & Tertiary & Chert & Debitage \\
\hline & $101 \mathrm{~N} / 98 \mathrm{E}$ & 2 & Tertiary & Chert & Debitage \\
\hline & Total & 16 & & & \\
\hline
\end{tabular}

recovered in the exterior excavations suggest that the fill may have come from somewhere near a dwelling, since they consist-with the exception of nails-almost entirely of household items. This fill was thoroughly mixed with the strata already present on the site by many different pipe-laying and landscaping operations.

The artifacts from the interior excavations are, with only a few exceptions, of nineteenth-century origin. The few exceptions-wire nails and the 1933 penny-were all found in the alcove area, near the walls, and could easily have been dropped there at some point shortly before (or while) the floor was paved and sealed with flagstone. The extent to which any Colonial-period levels remain intact is unknown, but the small number of Colonial-period artifacts suggests minimal disturbance.

One class of artifact is glaring in its absence: not one identifiable arms-related artifact was found. The combination of early souvenir hunters and later renovations and construction activities may have cleared all such remains from the areas excavated during this project. 


\section{Chapter Seven}

\section{Faunal Analysis}

A total of 1,515 animal bones and bone fragments was recovered during the project. In addition, 237 fragments of chicken-sized egg shell, all from the interior excavation, were recovered. A total of 1,255 ( 82.8 percent) of the bone was from the inside excavations and 260 (17.2 percent) was from the outside. Bones were identified to the genus and/or species level when possible, using the comparative collection at the CAR laboratory and several texts on faunal identification (Gilbert 1990; Hillson 1986; Olsen 1964, 1968).

\section{General Observations}

The bone found outside was generally in a good state of preservation, but the bone found in the interior excavations was in excellent condition. In the interior, although all screening used 1/4-inch mesh, entire maxillae of infant cotton rats were recovered unbroken and mouse skulls were found intact. The protected conditions inside the church and the very soft, dry, sandy matrix combined to insure excellent preservation and recovery of faunal remains. The total Number of Identified Specimens (NISP) of 380 is 25.1 percent of the total. The NISP in the exterior excavations was 37 (14.2 percent), and the NISP of the interior bone was 343 (27.3 percent). Table 8 lists identified species.

Bones from exterior and interior excavations are considered separately below. In each area, the identified bone was divided into two general categories: domestic and wild animals. The mammalian bone which could not be identified to the genus level was placed into categories according to the approximate size of the animal, if observable. These categories are Large Mammal, including horse-, cow-, and bison-sized animals; Medium Mammal, including deer-, goat-, and pig-sized animals; Small Mammal, including rabbit-, raccoon-, and skunk-sized animals; and Very Small Mammals, including rat- and mouse-sized animals. Mammalian bone too fragmentary to identify animal size is listed separately. Non-mammalian bone is listed according to taxonomic class, i.e. reptiles, fish, and birds (Reptilia, Osteichthyes, and Aves).

Calculations of the Minimum Number of Individuals (MNI), that is, the minimum number of animals which must have been present to account for the bone recovered, are commonly used to estimate the relative abundance of animal species in a site. The MNI is calculated by dividing the bone from a species by element and side, and then counting the most abundant element from one side as the MNI (Lyman 1994: 38-39). Age (juvenile or adult) and size are also usually taken into consideration. Grayson (1984:29-49) notes that using MNI has grave problems. He shows that the MNI of a species in a faunal collection can be greatly altered depending on how the faunal collection is aggregated by the analyst (see Grayson 1984:34-49 for examples). This remains a fundamental problem for the use of MNI in measuring abundance. The only way to avoid this problem is to insure that the degree to which a faunal collection is divided reflects the actual way in which faunal material was deposited in the site. Since both interior and exterior excavations are known to be disturbed, the MNI was calculated using the interior and exterior collections as individual groups. 
Table 8. Taxa Identified During Analysis

\begin{tabular}{|c|c|c|c|c|}
\hline Scientific Name & Common Name & $\begin{array}{c}\text { Interior } \\
\text { NISP }\end{array}$ & $\begin{array}{c}\text { Exterior } \\
\text { NISP }\end{array}$ & $\begin{array}{l}\text { Total } \\
\text { NISP }\end{array}$ \\
\hline \multicolumn{5}{|l|}{ MAMMALS } \\
\hline Bos taurus & Cattle & 13 & 20 & 33 \\
\hline Canis familiaris (?) & Domestic dog & 2 & 0 & 2 \\
\hline Capra hircus & Domestic goat & 0 & 1 & 1 \\
\hline Capra/Ovis & Goat/sheep & 5 & 3 & 8 \\
\hline Lepus californicus & Black-tailed jackrabbit & 2 & 0 & 2 \\
\hline Mephitis mephitis & Striped skunk & 32 & 0 & 32 \\
\hline Mus muscalis & House mouse & 2 & 0 & 2 \\
\hline Oryzomys palustris & Rice rat & 9 & 0 & 9 \\
\hline Peromycus maniculatus & Deer mouse & 5 & 0 & 5 \\
\hline Rattus rattus & Black rat, roof rat & 72 & 2 & 74 \\
\hline Sciurus niger & Fox squirrel & 35 & 0 & 35 \\
\hline Sigmodon hispidus & Hispid cotton rat & 139 & 7 & 146 \\
\hline Sus scrofa & Domestic pig & 6 & 1 & 7 \\
\hline Sylvilagus sp. & Cottontail rabbit & 4 & 0 & 4 \\
\hline \multirow{4}{*}{$\begin{array}{l}\text { Tayassu tajacu } \\
\text { (Pecari angulatus) }\end{array}$} & Javelina, collared peccary & 5 & 0 & 5 \\
\hline & Total Identified Mammals & 331 & 34 & 365 \\
\hline & Unidentified Mammals & 777 & 215 & 992 \\
\hline & Total Mammals & 1108 & 249 & 1357 \\
\hline \multicolumn{5}{|l|}{ REPTILES } \\
\hline \multirow[t]{4}{*}{ Trionyx sp. } & Softshell turtle & 2 & 0 & 2 \\
\hline & Total Identified Reptiles & 2 & 0 & 2 \\
\hline & Unidentified Reptiles & 0 & 1 & 1 \\
\hline & Total Reptiles & 2 & 1 & 3 \\
\hline \multicolumn{5}{|l|}{ FISH } \\
\hline & Unidentified Fish & 14 & 3 & 17 \\
\hline & Total Fish & 14 & 3 & 17 \\
\hline \multicolumn{5}{|l|}{ BIRDS } \\
\hline Meleagris gallopavo & Turkey & 2 & 1 & 3 \\
\hline Gallus domesticus & Chicken & 8 & 1 & 9 \\
\hline \multirow[t]{4}{*}{ Columbidae } & Dove/pigeon & 0 & 1 & 1 \\
\hline & Total Identified Birds & 10 & 3 & 13 \\
\hline & Unidentified Birds & 121 & 4 & 125 \\
\hline & Total Birds & 131 & 7 & 138 \\
\hline
\end{tabular}




\section{Exterior Excavations}

Faunal remains from the exterior excavations totaled 260 specimens, weighing $727.5 \mathrm{~g}$. The NISP for the area was 37 (14.2 percent). Table 9 is a summary of the vertebrate remains recovered from the exterior excavations. The exterior vertebrate remains appear to be almost entirely kitchen refuse, consisting largely of domestic animals, most with butcher marks. The total mammalian bone identifiable at least to size was 120. Cow and cow-sized animals dominate this group $(\mathrm{N}=74,61.7$ percent). Only 10 bones ( 3.9 percent of the total) were from animals not usually used for food in Western cultures. In short, the bone from the exterior excavations is consistent with other artifacts recovered in the area, i.e, evidence of a casual scatter of trash, largely domestic.

Table 9. Summary of Bone Recovered in Exterior Excavations

\begin{tabular}{|c|c|c|c|c|c|c|}
\hline Taxa & Count & $\begin{array}{l}\text { \% of } \\
\text { Total }\end{array}$ & $\begin{array}{l}\text { Weight } \\
\text { (g) }\end{array}$ & $\begin{array}{l}\% \text { of } \\
\text { Total }\end{array}$ & MNT & Notes \\
\hline \multicolumn{7}{|l|}{ Domestic Animals } \\
\hline Bos taurus & 20 & 7.7 & 281.9 & 38.7 & 2 & 1 juvenile \\
\hline Sus scrofa & 1 & 0.4 & 3.9 & 0.5 & 1 & \\
\hline Capra hircus & 1 & 0.4 & 7.7 & 1.1 & 1 & \\
\hline Caprid/Ovid & 3 & 1.2 & 9.3 & 1.3 & 0 & \\
\hline Meleagris gallopavo* & 1 & 0.4 & 1.3 & 0.2 & 1 & \\
\hline Gallus domesticus & 1 & 0.4 & 1.4 & 0.2 & 1 & \\
\hline Total Domestic Animals & 27 & 10.4 & 305.4 & 42.0 & 6 & \\
\hline \multicolumn{7}{|l|}{ Wild Animals } \\
\hline Sigmodon hispidus & 7 & 2.7 & 2.3 & 0.3 & 2 & \\
\hline Rattus rattus & 2 & .1 & .3 & 0.1 & 1 & \\
\hline Columbidae & 1 & 0.4 & .6 & 0.1 & 1 & \\
\hline Total Wild Animals & 10 & 3.9 & 3.3 & 0.5 & 4 & \\
\hline \multicolumn{7}{|c|}{ Unidentified Faunal Material, Categorized by Size or Class } \\
\hline Large Mammal & 54 & 20.8 & 281.0 & 38.6 & & \\
\hline Medium Mammal & 26 & 10.0 & 56.0 & 7.7 & & 1 juvenile \\
\hline Very Small Mammal & 6 & 2.3 & .7 & .1 & & \\
\hline Unidentified Mammal & 129 & 49.6 & 76.7 & 10.6 & & \\
\hline Unidentified Turtle & 1 & 0.4 & .4 & 0.1 & & \\
\hline Unidentified Fish & 3 & 1.2 & 1.1 & 0.2 & & \\
\hline Unidentified Bird & 4 & 1.5 & 2.4 & 0.3 & & \\
\hline Total Unidentified & 223 & 85.8 & 418.2 & 57.5 & & \\
\hline Overall Totals & 260 & & 727.5 & & 10 & \\
\hline
\end{tabular}

*The turkey (Meleagris gallopavo) is listed in domestic animals, it may have been wild. 


\section{Interior Excavations}

Vertebrate remains from the interior excavations were divided into the same categories as those from the exterior. The results are shown in Table 10. The total number of mammalian bone identifiable at least to size was 645 (51.4 percent of the total). Of these, rat and mouse-sized elements dominated with 412 (63.9 percent). The rest of the mammalian bone is a combination of wild and domestic animals commonly used for food, with the exception of the skunks, which probably fed on the numerous rats and mice.

Table 10. Summary of Bone Recovered in Interior Units

\begin{tabular}{|c|c|c|c|c|c|c|}
\hline Taxa & Count & $\begin{array}{l}\text { \% of } \\
\text { Total }\end{array}$ & $\begin{array}{c}\text { Weight } \\
\text { (g) }\end{array}$ & $\begin{array}{l}\text { \% of } \\
\text { Total }\end{array}$ & MNI & Notes \\
\hline \multicolumn{7}{|l|}{ Domestic Animals } \\
\hline Bos taurus & 13 & 1.0 & 366.5 & 30.6 & 2 & 1 juvenile \\
\hline Sus scrofa & 6 & 0.5 & 38.6 & 3.2 & 1 & \\
\hline Caprid/Ovid & 5 & 0.4 & 10.8 & 0.9 & 1 & \\
\hline Meleagris gallopavo* & 2 & 0.2 & 6.3 & 0.5 & 1 & \\
\hline Gallus domesticus & 8 & 0.6 & 11.8 & 1.0 & 2 & \\
\hline Canis sp. & 2 & 0.2 & 1.8 & 0.2 & 1 & \\
\hline Total Domestic & 36 & 2.9 & 435.8 & 36.4 & 8 & \\
\hline \multicolumn{7}{|l|}{ Wild Animals } \\
\hline Lepus californicus & 2 & 0.2 & 1.6 & 0.1 & 1 & \\
\hline Sylvilagus sp. & 4 & 0.3 & 1.2 & 0.1 & 1 & \\
\hline Sciurus niger & 35 & 3.0 & 4.9 & 0. & 2 & 1 juvenile \\
\hline Sigmodon hispidus & 139 & 11.1 & 27.5 & 2.3 & 10 & 4 juveniles \\
\hline Rattus rattus & 72 & 5.7 & 11.4 & 1.0 & 9 & 1 juvenile \\
\hline Oryzomys palustris & 9 & 0.7 & .6 & 0.1 & 3 & 2 juveniles \\
\hline Peromycus maniculatis & 5 & 0.4 & .1 & 0.01 & 2 & \\
\hline Mus muscalis & 2 & 0.2 & .1 & 0.01 & 1 & \\
\hline Mephitis mephitis & 32 & 2.8 & 7.2 & 0.6 & 2 & \\
\hline Tayassu tajacu & 5 & 0.4 & 18.8 & 1.6 & 1 & \\
\hline Trionix sp. & 2 & 0.2 & 2.8 & 0.2 & 1 & \\
\hline Total Wild Animals & 307 & 24.9 & 76.2 & 6.4 & 33 & \\
\hline \multicolumn{7}{|c|}{ Unidentified Faunal Material, Categorized by Size or Class } \\
\hline Large Mammal & 80 & 6.37 & 350.21 & 29.3 & & \\
\hline Medium Mammal & 57 & 4.54 & 85.20 & 7.1 & & 1 is from juvenile \\
\hline Small Mammal & 29 & 2.31 & 10.02 & 0.8 & & 1 is from juvenile \\
\hline Very Small Mammal & 150 & 11.95 & 10.31 & 0.9 & & \\
\hline Unidentified Mammal & 461 & 36.73 & 174.55 & 14.6 & & \\
\hline Unidentified Fish & 14 & 1.12 & 1.75 & 0.2 & & \\
\hline Unidentified Bird & 121 & 9.64 & 52.50 & 4.4 & & \\
\hline Total Unidentified & 912 & 72.66 & 684.54 & 57.2 & & \\
\hline Totals & 1255 & & 1196.44 & & 41 & \\
\hline
\end{tabular}

*The turkey (Meleagris gallopavo) is listed in domestic animals, it may have been wild. 
As mentioned above, the preservation of bone inside the Alamo church was unusually good. This made the identification of some of the tiny bones of mice and infant rats much easier. The sharp eyes of the screeners must also be recognized-in one case the calcaneus of an infant $S$. hispidus was recovered. However, despite the good preservation, 36.7 percent of the mammalian bone was too fragmentary to even identify the size of the animal.

Highly fragmented bone like this is common in mission sites (Brown et al. 1994:17; Hard et al. 1995:82; McClure 1982:109; Meissner 1993:27; Rawn 1977:144). It appears to be, at least to some extent, the result of deliberate breakage of the bone while still fresh, most likely for marrow extraction, boiling for bone grease, or both.

The identifiable interior faunal remains are dominated by the number of rats and mice, with a count of 227 (66.2 percent of the total identified) and an MNI of 25. The use of the church as a warehouse for approximately 32 years accounts for this large number of rodents.

\section{Discussion}

The identified bone from the exterior is dominated by domestic animals commonly used for food, while only 10 bones ( 3.9 percent) of non-domestic animals were recovered. This dominance of kitchen refuse is also seen in other artifact classes.

Other than the large number of rodents, the interior is most notable for the wide variety of taxa represented. Seventeen different species were identified in the interior, compared to only eight in the exterior. While this may be due to differences in excavation technique, the presence of some Very Small Mammal bone in the exterior does indicate that at least some of these smaller animals were being recovered. Note that the MNI of domestic animals is six in the exterior and eight in the interior collection. The difference between interior and exterior is almost all due to the large number of wild species identified in the interior.
The total MNI for the exterior was 10, with 6 (66.7 percent) from domestic animals (see Table 9). The total MNI for the interior was 41 , with 8 (19.5) from domestic animals (see Table 10). The MNI of rats and mice in the interior was 25 ( 61.0 percent), while only 3 (33.3 percent) of the exterior MNI were rats and mice. The high percentage of rodent remains (excluding the squirrel remains), both in NISP (66.4 percent) and MNI (61.0 percent), in the interior excavations is, again, probably a reflection of the use of the building as a warehouse.

If attention is focused on animals most likely to have formed a significant part of the diet-i.e., domestic food animals such as cattle, pigs, goats and sheep, and wild animals such as rabbits, deer, racoon, opossum, javelina, and squirrel-an interesting comparison can be made with results from a recent analysis of faunal material from Mission San José y San Miguel de Aguayo (Hard et al. 1995). Table 11 shows a comparison of the domestic and wild food species listed above from levels believed to be largely Colonial at San José, levels believed to be largely nineteenth century at San José (Hard et al. 1995:93, Table 24), and the exterior and interior excavations at the Alamo.

The nineteenth-century levels from San José and the exterior of the Alamo have no non-domestic food animals. The Colonial levels at San José have roughly 80 percent domestic animals, while the interior Alamo has only about half that percentage of domestic food animals. If, as the artifact analyses indicate, the sediments in the interior of the Alamo are largely nineteenth century in origin, why are there so many wild animals which are likely to have formed part of the diet found there, unlike sediments of similar age at San José and the exterior of the Alamo? Most of these remains come from the area in which caliche floor seems most disturbed by rodent and/or human activity, and in which the lower levels have been mixed with the sediments containing nineteenthcentury artifacts.

However, even if we assume that a high percentage of the bone came from Colonial levels disturbed by 
Table 11. Comparison of Selected Faunal Material from Mission San Jose and the Alamo

\begin{tabular}{|r|c|c|c|c||}
\cline { 2 - 5 } \multicolumn{1}{c|}{} & \multicolumn{4}{c|}{$\begin{array}{c}\text { Total Selected Food } \\
\text { Animal Remains }\end{array}$} \\
\hline \multirow{2}{*}{ Provenience } & \multicolumn{3}{c|}{ Domestic } & \multicolumn{2}{c|}{ Wild } \\
\cline { 2 - 5 } & $\mathrm{N}$ & $\%$ & $\mathrm{~N}$ & $\%$ \\
\hline Colonial levels at San José & 162 & 81.4 & 37 & 18.6 \\
\hline Nineteenth century levels at San José & 28 & 100.0 & 0 & 0.0 \\
\hline Exterior Alamo & 27 & 100.0 & 0 & 0.0 \\
\hline Interior Alamo & 34 & 42.5 & 46 & 57.5 \\
\hline
\end{tabular}

rodent or human activities, which is not very likely considering the dates of the other artifact classes present, the percentage of wild animal remains is much larger than that found in colonial levels at San Jose. The reason for this difference is not known. If further excavations on the interior of the Alamo are done, it will be interesting to see if this high percentage of wild animals is found consistently.

Only two bones in the interior, both unidentifiable bird of about chicken size, showed evidence of burning. As discussed in Chapter 5, this fact suggests that the bone was not present, at least in its current position relative to the surface, when the fires of 1836 and 1861 occurred.

The faunal analysis confirms the impressions from excavations and analysis of artifacts. Faunal material from the exterior excavation, like the artifacts, appears to be scattered kitchen refuse. The faunal collection from the interior has more wild animal species represented. The number of rats and mice is particularly high, and ratios of domestic vs. wild food animal remains are more like the Colonial period than the nineteenth century levels at San Jose. The large number of chicken-sized egg fragments may reflect the use of the building as a warehouse. 


\section{Chapter Eight}

\section{Summary and Recommendations}

$\mathrm{T}$ This project adds to the growing body of archaeological information about the Alamo that has been accumulating since 1966 . This section is a summary of that information and a list of recommendations for any further work done in the immediate vicinity of the Alamo church.

\section{Summary}

Previous excavations at the Alamo have consistently found Colonial-period artifacts associated with a level of packed caliche. This layer of caliche was also identified in this project, at or just below the level of the top of the foundation, both inside and out, at a depth consistent with Eaton's (1980) excavations. However, the parameters of the project did not include excavation below this level, so we cannot confirm the association of Colonial-period artifacts with this layer. The depth of the caliche layer (Figure 82) as well as the small numbers of recovered Colonial-period artifacts does suggest that Colonial levels may not have been heavily disturbed in either the interior or exterior.

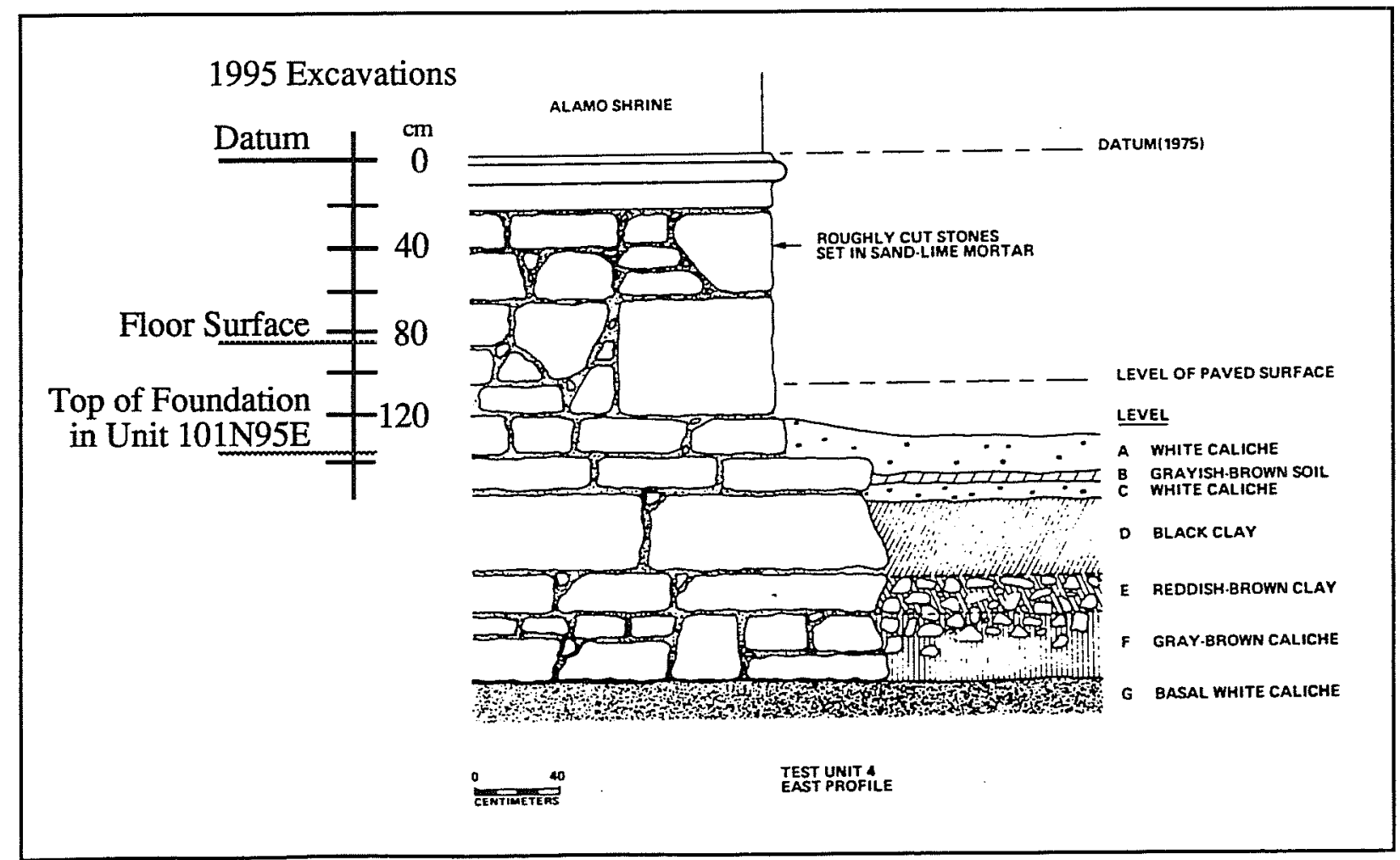

Figure 82. Comparison of depth of caliche layer in Eaton (1980:52) and current project. Eaton's drawing of the Alamo foundation, on the right, is compared with measurements from the 1995 excavations. 
Although the artifacts recovered during the project represent every period since construction, there is no direct evidence of the event that made the Alamo so famous, the siege and battle of February and March 1836. The reasons for this are probably very simple. The exterior excavations have shown that sediments outside the south transept have been heavily disturbed, and partly consist of sediment brought in from unknown locations. During the battle, the interior of the building was nearly filled with the ramp built by General Cós to place cannon on the upper walls. Evidence of the battle would therefore have been removed with the remains of the ramp by the U.S. Army in 1850.

After the Battle of the Alamo, Alamo Plaza was almost deserted for a decade, being used primarily as a playground, though visitors to the city often visited the site. The use of the old mission buildings by the U.S. Army as a Quartermaster's Corps depot led directly to the development of Alamo Plaza as a major center of commerce in the rapidly growing city. A police station built attached to the exterior of the Alamo chapel in 1878 was a response to growing urbanization around Alamo Plaza. The removal of the police station in 1896 was in response to a growing desire to give the old building the respect it was due, as well as the realization that tourism could be a major business in San Antonio, with the Alamo as the center of this industry. The importance, both social and commercial, of the historic old building had been recognized.

The interior excavations have a mixture of nineteenthcentury and Colonial material. The historical documentation, the sediments, and artifacts analyzed in this project suggest that-at least in the south transept-the Colonial-period surface, any remnants of General Cós's ramp, and the floor of the nineteenth-century warehouse have been partially mixed, mostly by rodent activity. The extent to which there may be more extensive Colonial-period artifact deposits beneath the level of these excavations cannot, of course, be determined without further excavation. However, any excavation which goes below this level may encounter human remains, and possibly even intact burials. This possibility should always be taken into consideration when planning excavations in the interior of the church.

The excavations in the exterior demonstrated considerable disturbance and mixing of sediments in the area near the south transept; however, the degree and kind of disturbance was not consistent in all excavation units. Although the sediments along the south wall of the south transept, designated Area C, were heavily and recently disturbed down to the depth of the foundation, the distinct stratum of caliche/clay mixture east of the south transept appears to be an intact late-eighteenth-/early nineteenth-century layer. If this layer, which contains numerous artifacts, is present in other areas around the building, an opportunity to learn much more about the time span between the end of the Colonial period and the Battle of the Alamo may be available. In addition, if this is indeed an undisturbed nineteenth-century layer, there is likely an undisturbed Colonial-period stratum below it. If the Colonial stratum is consistently at or below the top of the foundation, then it will probably not be necessary to seriously disturb it in any future excavations with similar requirements.

\section{Recommendations}

If the current experiment at the south transept of the Alamo proves successful in stopping the deterioration of the walls, the DRT plans to treat the rest of the building in a similar manner. The following recommendations for archaeological work associated with such an endeavor are based on the information gained from this and previous projects at the Alamo.

1) In order to make planning for further archaeological work more efficient, we recommend that a series of test units be excavated, especially along the exterior walls. These test units should be placed so that the sediments along each section of wall can be examined. Considerable variation in the depths at which undisturbed sediments may be discovered is possible. Special 
attention should be paid to the layers just above the foundation, as these may contain intact early nineteenth-century deposits.

2) The presence of a Colonial layer at or just below the level of the foundation is likely, and plans should be made to avoid these deposits, if possible.

3) In the interior, the degree of disturbance seen in the south transept cannot be assumed to be the same throughout the building. All excavations in the interior should be handdug. Disturbance of the packed caliche level, if encountered, should be avoided if possible.

4) Collection of three-point provenience on all dateable artifacts should be considered, as this may help in determining the extent of sediment mixing.

5) It must be assumed that any additional interior excavations will encounter human osteological remains, including scattered, disarticulated bones and possibly intact burials. No intact burials were found above the caliche layer near the top of the foundation; however, it cannot be assumed that this will always be the case. A detailed plan for dealing with the potential for finding human remains should be in place before excavation begins.

6) In addition, care should be taken to avoid collapsing soft sediments, as such events may encroach on sediments not scheduled for excavation, as was the case in this project. All persons should avoid walking on unprotected surfaces. Plywood can be used to cover units not currently being excavated in order to support the weight of the archaeologists and others. 


\section{References Cited}

Abernethy, F. E. (editor)

1989 Texas Toys and Games. Southern Methodist University Press, Dallas.

Abramovitch, I.

1995 Yellow Ware. In Martha Stewart Living 27:98-103.

Albert, L. S., and K. Kent

1949 The Complete Button Book. Appledore, Stratford, Connecticut.

Almaráz, F. D.

1971 Tragic Cavalier: Governor Manuel Salcedo of Texas, 1808-1813. University of Texas Press, Austin.

Barber, L. L. (editor)

1973 The Doctors Herff: A Three-generation Memoir. Trinity University Press, San Antonio.

Barnes, M. R.

1975 Mexican Lead-Glazed Earthenwares. Manuscript on file at the Center for Archaeological Research, The University of Texas at San Antonio.

Barr, L.

1990 Texans in Revolt: The Battle for San Antonio, 1835. University of Texas Press, Austin.

Baugher-Perlin, S.

1982 Analyzing Glass Bottles for Chronology, Function, and Trade Networks. In Archaeology of Urban America: The Search for Pattern and Process, edited by R. S. Dickens, pp. 259-289. Academic, New York.

Black, S. J.

1985a Central Texas Plateau Prairie. In From Gulf Coast to the Rio Grande: Human Adaptation in Central, South and Lower Pecos Texas, edited by T. R. Hester, S. L. Black, D. G. Steele, B. W. Olive, A. A. Fox, K. J. Reinhard, and L. C. Bement, pp. 17-38. Research Series No. 33, Arkansas Archeological Survey, Fayetteville.

1985b Environmental Setting. In From Gulf Coast to the Rio Grande: Human Adaptation in Central, South and Lower Pecos Texas, edited by T. R. Hester, S. L. Black, D. G. Steele, B. W. Olive, A. A. Fox, K. J. Reinhard, and L. C. Bement, pp. 5-16. Research Series No. 33, Arkansas Archeological Survey, Fayetteville.

Black, S. J., and A. J. McGraw

1985 The Panther Springs Creek Site: Cultural Change and Continuity in the Upper Salado Creek Drainage, South-Central Texas. Archaeological Survey Report, No. 100. Center for Archaeological Research, The University of Texas at San Antonio. 
Blair, W. F.

1950 The Biotic Provinces of Texas. Texas Journal of Science 2(1):93-117.

Bolton, H.E.

1970[1915] Texas in the Middle Eighteenth Century: Studies in Spanish Colonial History and Administration. University of Texas Press, Austin.

Bowden, J. J.

1986 The Exodus of Federal Forces from Texas 1861. Eakin, Austin.

Briggs, A. K.

1993 Archeological Testing, Trenching and Excavations for the Alamo Sales Museum Expansion Project at the Alamo Shrine and Museum (Mission San Antonio de Valero), in San Antonio, Bexar County, Texas. Manuscript on file at the Library of the Daughters of the Republic of Texas, San Antonio.

Brown, M. J., A. A. Fox, and B. A. Meissner

1994 Archaeological Testing for the Mission Road Realignment Project, Phase II, At Mission Concepcion, San Antonio, Texas. Archaeological Survey Report, No. 222. Center for Archaeological Research, The University of Texas at San Antonio.

Burkhalter, L. (editor)

1961 A Seth Eastman Sketchbook, 1848-1849. University of Texas Press, Austin.

Burt, W. H., and R. P. Grossenheider

1976 A Field Guide to the Mammals of America North of Mexico. Third edition. Houghton Mifflin, Boston.

Byfield, M.

1986 Dolls' House Dolls. In The Best of the Doll Reader, Volume II, compiled by V. A. Heyerdahl, pp. 35-38. Hobby House, Cumberland, Maryland.

Campbell, T. N.

1975 The Payaya Indians of South Texas. Special Publication No. 1. Southern Texas Archaeological Association, San Antonio.

Campbell, T. N., and T. J. Campbell

1985 Indian Groups Associated with the Spanish Missions of the San Antonio Missions National Historic Park. Special Report, No. 16. Center for Archaeological Research, The University of Texas at San Antonio.

Castañeda, C. E.

1938 Our Catholic Heritage in Texas, Volume II. Von Boeckman-Jones, Austin.

Chabot, F. C.

1935 The Alamo: Mission, Fortress, and Shrine, A History of the Altar of Texas Liberty. Naylor, San Antonio.

City Public Service

1976 How Did We Get Where We Are Today? Manuscript on file at the Daughters of the Republic of Texas Library, San Antonio.

Collins, M. B.

1995 Forty Years of Archaeology in Texas. Bulletin of the Texas Archeological Society 66:361-400. 
Corner, W.

1890 San Antonio de Bexar: A History and Guide. Bainbridge and Corner, San Antonio.

Cox, I. W.

1990 Field Survey and Archival Research for the Rosillo Creek Battleground Area, Southeast San Antonio, Texas. Archaeological Survey Report, No. 177. Center for Archaeological Research, The University of Texas at San Antonio.

1994 The History and Development of Alamo Plaza. In A Historical Overview of Alamo Plaza and Camposanto, edited by R. J. Hard, pp.1-35. Special Report, No. 20. Center for Archaeological Research, The University of Texas at San Antonio.

1995 The Murderer in the Mission. Manuscript on file, Center for Archaeological Research, The University of Texas at San Antonio.

Dabney Group

1985 On-Site Reconnaissance, Chemical and Petrographic Studies of Stone and Mortar Materials at the Alamo Shrine, San Antonio, Texas. Report on the Alamo Study for the Alamo Committee of the Daughters of the Republic of Texas, on file at the Center for Archaeological Research, The University of Texas at San Antonio.

Darrow, C. D.

1884-1887 Recollection of the Twiggs Surrender. In Battles and Leaders of the Civil War: Being For the Most Part Contributions by Union and Confederate Officers: Based Upon "The Century War Series, "edited by R. U. Johnson and C. C. Buel, pp.33-39. Century, New York.

Daughters of the Republic of Texas Library

1994 DRT/Alamo Complex Chronology. Manuscript on file at the Daughters of the Republic of Texas Library, San Antonio.

Davis, E. M., and J. E. Corbin

1967 Archeological Investigations at Washington-on-the-Brazos State Park in 1966. Report No. 5. State Building Commission Archeological Program, Austin.

Deagan, $\mathrm{K}$.

1987 Artifacts of the Spanish Colonies of Florida and the Caribbean, 1500-1800, Volume: Ceramics, Glassware, and Beads. Smithsonian Institution Press, Washington, D.C.

de la Peña, J. E.

1975 With Santa Anna in Texas: A Personal Narrative of the Revolution. Translated and edited by C. Perry. Texas A\&M University Press, College Station.

de la Teja, J. F.

1995 San Antonio de Bexar: A Community on New Spain's Northern Frontier. University of New Mexico Press, Albuquerque.

Dial, S. W.

1992 Ceramics. In Archaeological Investigations in Alamo Plaza, San Antonio, Bexar County, Texas: 1988 and 1989, by A. A. Fox, pp. 29-47. Archaeological Survey Report, No. 205. Center for Archaeological Research, The University of Texas at San Antonio. 
Durrenberger, E. P.

1965 Anderson's Mill (41 TV 130): A Historic Site in Travis County, Texas. In Bulletin of the Texas Archeological Society 36:1-69.

Eaton, J. D.

1980 Excavations at the Alamo Shrine (Mission San Antonio de Valero). Special Report, No. 10. Center for Archaeological Research, The University of Texas at San Antonio.

Edgerton, C. E.

1897 The Wire-Nail Association of 1895-1896. Political Science Quarterly 12:246-272.

Epstein, D., and M. Safro

1991 Buttons. Abrams, New York.

Everett, D. E.

1975 San Antonio: The Flavor of Its Past, 1845-1898. Trinity University Press, San Antonio.

Faulk, O. B., and J. A. Stout (editors)

1973 The Mexican War: Changing Interpretations. Swallow, Chicago.

Fehrenbach, T. R.

1968 Lone Star: A History of Texas and the Texans. Macmillan, Toronto.

Filisola, V.

1985[1848] Memoirs for the History of the War in Texas. Vol. I, translated by W. Woolsey. Eakin, Austin.

Fox, A. A.

1977 The Archaeology and History of the Spanish Governor's Palace Park. Archaeological Survey Report, No. 31. Center for Archaeological Research, The University of Texas at San Antonio.

1986 Archaeological Investigations at the United States Arsenal Site (41BX622), San Antonio, Texas. Archaeological Survey Report, No. 137. Center for Archaeological Research, The University of Texas at San Antonio.

Fox, A. A., F. A. Bass, and T. R. Hester

1976 The Archaeology and History of Alamo Plaza. Archaeological Survey Report, No. 16. Center for Archaeological Research, The University of Texas at San Antonio.

Fox, D. E.

1970 Archaeological Salvage at Mission San José, December 1969, April and August, 1970. Texas Historical Survey Committee, Austin.

Garrett, J. K.

1968[1939] Green Flag Over Texas: A Story of the Last Years of Spain in Texas. Pemberton, Austin.

Gilbert, B. M.

1990 Mammalian Osteology. Missouri Archaeological Society, Columbia.

Gilmore, $\mathrm{K}$.

1974 Mission Rosario: Archeological Investigations 1973. Archeological Report No. 14. Texas Parks and Wildlife Department, Austin. 
Godden, G. A.

1965 An Illustrated Encyclopedia of British Pottery and Porcelain. Bonanza Books, New York.

Grayson, D. K.

1984 Quantitative Zooarchaeology. Academic, New York.

Greer, G. H.

1981 American Stonewares: The Art and Craft of Utilitarian Potters. Schiffer, Exton, Pennsylvania.

Greer, G. H., and H. Black

1971 The Meyer Family: Master Potters of Texas. Trinity University Press, San Antonio.

Greer, J. W.

1967 A Description of the Stratigraphy, Features and Artifacts form an Archeological Excavation at the Alamo. Report No. 3. State Building Commission Archeological Program, Austin.

Gross, K. J., and F. Meissner

1997 Architectural Material. In Archaeology at the Alamodome: Investigations of a San Antonio Neighborhood in Transition, Vol. III: Artifacts and Special Studies, edited by A. A. Fox, M. Renner, and R. J. Hard. Archaeological Survey Report, No. 238. Center for Archaeological Research, The University of Texas at San Antonio. In press.

Habig, M. A.

1968 The Alamo Chain of Missions: A History of San Antonio 's Five Old Missions. Franciscan Herald, Chicago.

Hard, R. J. (editor)

1994 A Historical Overview of Alamo Plaza and Camposanto. Special Report, No. 20. Center for Archaeological Research, The University of Texas at San Antonio.

Hard, R. J., A. A. Fox, I. W. Cox, K. J. Gross, B. A. Meissner, G. Mendez, C. L. Tennis, and J. Zapata.

1995 Excavations at Mission San José y San Miguel de Aguayo, San Antonio, Texas. Archaeological Survey Report, No. 218. Center for Archaeological Research, The University of Texas at San Antonio.

Harpur, P. (editor)

1982 The Timetable of Technology: A Record of the Twentieth Century's Amazing Achievements. Hearst Books, New York.

Hemion, R. H.

1978 Light in San Antonio. Manuscript on file, Center for Archaeological Research, The University of Texas at San Antonio.

Herment, G.

1957 The Pipe: A Serious Yet Diverting Treatise On The History Of The Pipe And All Its Appurtenances, As Well As A Factual Withal Philosophical Discussion Of The Pleasurable Art Of Selecting Pipes, Smoking, And Caring For Them. Translated by A. L. Hayward. Simon and Schuster, New York.

Hester, T. R., S. L. Black, D. G. Steele, B. W. Olive, A. A. Fox, K. J. Reinhard, and L. C. Bement

1989 From Gulf Coast to the Rio Grande: Human Adaptation in Central, South and Lower Pecos Texas. Research Series No. 33. Arkansas Archeological Survey, Fayetteville. 
Hillson, S.

1986 Teeth. Cambridge University Press, Cambridge.

Hinojosa, G.M.

1991 The Religious-Indian Communities: The Goals of the Friars. In Tejano Origins in Eighteenth-Century San Antonio, edited by G. E. Poyo and G.M. Hinojosa, pp. 61-83. University of Texas Press, Austin.

Hodge, L. D., and S. S. Victor

1983 D'Hanis Brick and Tile Going Full Steam After a Century of Operation. Texas Architect, JulyAugust:77-78.

Huebner, J. A.

1991 Late Prehistoric Bison Populations in Central and Southern Texas. Plains Anthropologist 36(137):343-358.

Humphreys, S. B.

1971 Skeletal Biology of Eighteenth Century Coahuiltecan Indians from San Juan Capistrano Mission, San Antonio, Texas. Masters thesis on file, Center for Archaeological Research, The University of Texas at San Antonio.

Ivey, J. E.

1983 Archaeological Testing at Rancho de Las Cabras, 41 WN 30, Wilson County, Texas: Second Season. Archaeological Survey Report, No. 121. Center for Archaeological Research, The University of Texas at San Antonio.

Ivey. J. E., and A. A. Fox

1981 Archaeological Survey and Testing at Rancho de Las Cabras, Wilson County, Texas. Archaeological Survey Report, No. 104. Center for Archaeological Research, The University of Texas at San Antonio.

1997 Archaeological and Historical Investigations at the Alamo North Wall (41BX6), San Antonio, Bexar County, Texas. Archaeological Survey Report, No. 224. Center for Archaeological Research, The University of Texas at San Antonio. In press.

Ivey, J. E., M. B. Thurber, and S. Escobedo

1990 Of Various Magnificence: The Architectural History of the San Antonio Missions in the Colonial Period and the Nineteenth Century, Volume One. San Antonio Missions National Historical Park. Manuscript on file, Center for Archaeological Research, The University of Texas at San Antonio.

Jenkins, J. H.

1973 Recollections of Early Texas: The Memoirs of John Holland Jenkins. Edited by J. H. Jenkins. University of Texas Press, Austin.

Jenkins, J. H. (editor)

1973 The Papers of the Texas Revolution, Volume 3. Presidial, Austin.

John, E. A. H.

1975 Storms Brewed in Other Men's Worlds: The Confrontation of Indians, Spanish, and French in the Southwest, 1540-1795. Texas A\&M University Press, College Station. 
Johnson, L., and G. T. Goode

1994 A New Try at Dating and Characterizing Holocene Climates, as Well as Archaeological Periods, on the Eastern Edwards Plateau. Bulletin of the Texas Archeological Society 65:1-51.

Kendrick, G.

1967 Bottle Fragments Betray Age of Historic Sites. El Palacio 74(2):19-24.

Kerby, R. L.

1972 Kirby Smith's Confederacy: The Trans-Mississippi South, 1863-1865. Columbia University Press, New York.

Kilgore, D.

1978 How Did Davy Die? Texas A\&M University Press, College Station.

Leal, J. O., translator

1978 Burials of Mission San Francisco de Solano (San Antonio de Valero, (Alamo). Manuscript on file, Daughters of the Republic of Texas Library, San Antonio.

Lister, F. C., and R. H Lister

1974 Maiolica in Colonial Spanish America. Historical Archeology 8:17-52.

Lockett, T. A.

1972 Davenport Pottery and Porcelain 1794-1887. Charles E. Tuttle, Rutland, Vermont.

Lord, W.

1961 A Time to Stand: The Epic of the Alamo. University of Nebraska Press, Lincoln.

Lorraine, D.

1968 An Archaeologist's Guide to Nineteenth Century American Glass. Historical Archaeology 2:35-44.

Lyman, R. L.

1994 Quantitative Units and Terminology in Zooarchaeology. American Antiquity 59(1):36-71.

May, R. V.

1972 An Evaluation of Mexican Majolica in Alta California Employing Preliminary Data from the San Diego Presidio. In Mexican Majolica in Northern New Spain, edited by M. R. Barnes and R. V. May, pp. 25-50. Occasional Paper No. 2. Pacific Coast Archaeological Society, Costa Mesa, California.

McClure, W.

1982 Faunal Analysis for 41BX12, Mission Concepción Dump. In Archaeological Investigations at Mission Concepcion and Mission Parkway, edited by J. E. Ivey and A. A. Fox, pp.105-111. Archaeological Survey Report, No. 114. Center for Archaeological Research, The University of Texas at San Antonio.

Meissner, B. A.

1993 Faunal Remains Recovered During San Juan Drainage Project. In Archaeological Testing and Monitoring in Connection with a Drainage Project at Mission Jan Juan Capistrano, San Antonio, Bexar County, Texas, edited by A. A. Fox, pp.27-35. Archaeological Survey Report, No. 217. Center for Archaeological Research, The University of Texas at San Antonio. 
Menchaca, A.

1937 Memoirs. Yanaguana Society Publications, Vol. 2. Yanaguana Society, San Antonio.

Meskill, F. K.

1992 Archaeological Testing Within the Southeast Comer of the Plaza at Mission Espada, San Antonio, Bexar County, Texas. Archaeological Survey Report, No. 208. Center for Archaeological Research, The University of Texas at San Antonio.

Miller, G. L., and R. R. Hunter

1990 English Shell Edged Earthenware: Alias Leeds Ware, Alias Feather Edge. In Thirty-fifth Annual Wedgewood International Seminar May 2, 3, 4, and 5, 1990: The Consumer Revolution in Eighteenth Century English Pottery, edited by C. Mazzola, pp.107-136. Birmingham Museum of Art, Birmingham, Alabama.

Miller, G. L., and A. Pacey

1985 Impact of Mechanization in the Glass Container Industry: The Dominion Glass Company of Montreal, A Case Study. Historical Archaeology 19(1):38-50.

Montgomery, R. G., W. Smith, and J. O. Brew

1949 Franciscan Awatovi: The Excavation and Conjectural Reconstruction of a 17th-Century Spanish Mission Establishment at a Hopi Indian Town in Northeastern Arizona. Reports of the Awatovi Expedition Peabody Museum, Harvard University, Report No. 3. Peabody Museum, Cambridge.

Montgomery Ward \& Co.

1969[1895] Montgomery Ward \& Co. Catalogue and Buyers Guide 1895. Dover, New York.

Munsey, C.

1970 The Illustrated Guide to Collecting Bottles. Hawthorn Books, New York.

Nickels, D. L.

1997 An Archaeological Assessment of the Drainage Improvement Area on the Northeast Side of Alamo Hall, and Home of Former Mayor Wilhelm Thielepape (41BX507), San Antonio, Texas. Archaeological Survey Report, No. 244. Center for Archaeological Research, The University of Texas at San Antonio. In press.

Olsen, S. J.

1964 Mammal Remains from Archaeological Sites Part 1; Southeastern and Southwestern United States. Peabody Museum, Cambridge.

1968 Fish, Amphibian, and Reptile Remains from Archaeological Sites Part I: Southeastern and Southwesterm United States. Peabody Museum, Cambridge.

Paulus, $\mathbf{M}$.

1939 Fifteen Years in Old San Antonio, 1850-1865. Master's thesis on file, Center for Archaeological Research, The University of Texas at San Antonio.

Pertulla, T. K., and N. Reese (editors)

1995 Bulletin of the Texas Archeological Society 66. 
Pool, J. C.

1987 Fanthorp Inn: A Study of Nineteenth and Twentieth Century Buttons. Archeological Excavations at Fanthorp Inn State Historic Site (41GM79), Grimes County, Texas, Spring and Fall 1982, edited by J. D. Ing and J. Hart, pp. 277-290. Texas Parks and Wildlife Department, Austin.

Ramsay, J.

1976 American Potters \& Pottery. Ars Ceramica, Ann Arbor.

Rawn, V. M.

1977 Analysis of the Bone Material. In An Archaeological Investigation of Mission Concepcion, San Antonio, Texas, edited by D. Scurlock and D. E. Fox, pp. 143-152. Office of the State Archeologist, Report No. 28. Texas Historical Commission, Austin.

Rice, $\mathrm{P}$.

1987 Pottery Analysis: A Source Book. University of Chicago Press, Chicago.

Robacker, E. F., and A. F. Robacker

1978 Spatterware and Sponge: Hardy Perennials of Ceramics. A.S. Barnes and Company, New York.

Roberson, W. R.

1974 The Carrington-Covert House: Archeological Investigation of a nineteenth-Century Residence in Austin, Texas. Office of the State Archeologist, Report No. 25. Texas Historical Commission, Austin.

San Antonio Daily Express [SADE],

1896 Mackey Makes a Dire Threat. 3 February:8.

1896 Work on the Alamo Stopped. 5 April.

1896 The Alamo Repairs, 6 April.

1937 Bone of 4 Alamo Martyrs Dug Up in Historic Chapel. 5 January.

1937 Texas University Museum Curator Asked to Shed Light On Bones of Four Found in Alamo Chapel. 6 January.

1937 Bones Reburied in Alamo Floor. 12 May.

San Antonio Express-News

197711 October:1B.

San Antonio Light

1937 Bone Found in Shrine. 5 January.

1969 September 27.

Schoelwer, S.P.

1985 Alamo Images: Changing Perceptions of a Texas Experience. DeGolyer Library and Southern Methodist University Press, Dallas.

Schuetz, M. K.

1966 Historic Background of the Mission San Antonio de Valero. Report No. 1. State Building Commission Archeological Program, Austin.

1968 The History and Archeology of Mission San Juan Capistrano, San Antonio, Texas, Vol. I: Historical Documentation and Description of the Structures. Report No. 10. State Building Commission Archeological Program, Austin. 
1969 The History and Archeology of Mission San Juan Capistrano, San Antonio, Texas, Vol. II: Description of the Artifacts and Ethno-History of the Coahuiltecan Indians. Report No. 11. State Building Commission Archeological Program, Austin.

1973 Archeological Investigations at Mission San Antonio de Valero: The Second Patio. Manuscript on file, Center for Archaeological Research, The University of Texas at San Antonio.

Sellari, C., and D. Sellari

1975 The Illustrated Price Guide of Antique Bottles. Country Beautiful, Waukesha, Wisconsin.

Sorrow, W. M.

1972 Archeological Salvage Excavations at the Alamo (Mission San Antonio de Valero) 1970. Texas Archeological Salvage Project, Research Report No. 4. The University of Texas at Austin.

Stirn, C. P.

1990[1893] Tum of the Century Dolls, Toys, and Games: The Complete Illustrated Catalog from 1893. Dover, New York.

Story, A. B.

1938 The Alamo from Its Founding to 1937. Master's thesis, The University of Texas at Austin. Copy on file, Daughters of the Republic of Texas Library, San Antonio.

Sudbury, B.

1979 Historic Clay Pipemakers in the United States of America. In The Archaeology of the Clay Tobacco Pipe, Vol. 2: The United States of America, edited by P. Davey, pp.151-341. Bar International Series \#60, Oxford.

Sweet, A. J., and J. A. Knox

1905 On a Mexican Mustang Through Texas: From the Gulf to the Rio Grande. Chatto and Windus, London.

Tennis, C. L.

1995 Exhumation of a Hero, Colonel Ben Milam: Milam Park Renovation, Phase I. Archaeological Survey Report, No. 223. Center for Archaeological Research, The University of Texas at San Antonio.

Tijerina, A.

1994 Tejanos and Texas Under the Mexican Flag, 1821-1836. Texas A\&M University Press, College Station.

Toulouse, J. H.

1971 Bottle Makers and Their Marks. Thomas Nelson, New York.

Utterback, M. D.

1963 Eighteenth Century English Glass. Witte Museum Quarterly 1(2):27-40.

Whittemore, J.

1992 The Book of Buttons. Dorling Kinsersley, New York.

Weigley, R. F.

1986 American Strategy from Its Beginnings Through the First World War. In Makers of Modern Strategy: From Machiavelli to the Nuclear Age, edited by P. Paret, pp.408-443. The University Press, Princeton. 
White, T. D.

1991 Human Osteology. Academic, New York.

Williams, A.

1933 A Critical Study of the Siege of the Alamo and the Personnel of its Defenders. Southwestern Historical Quarterly 36:252-287, 37:1-44, 79-115, 157-184, 237-312.

Woolford, S. (editor)

1963 San Antonio, A History for Tomorrow. Naylor, San Antonio.

Young, K. R.

1991 Notes and Related Correspondence covering the United States Army Quarter Masters' Occupation of the Alamo-1846-1854. Manuscript on file, Center for Archaeological Research, The University of Texas at San Antonio.

Young, J. H.

1961 The Toadstool Millionaires: A Social History of Patent Medicines in America Before Federal Legislation. The University Press, Princeton. 


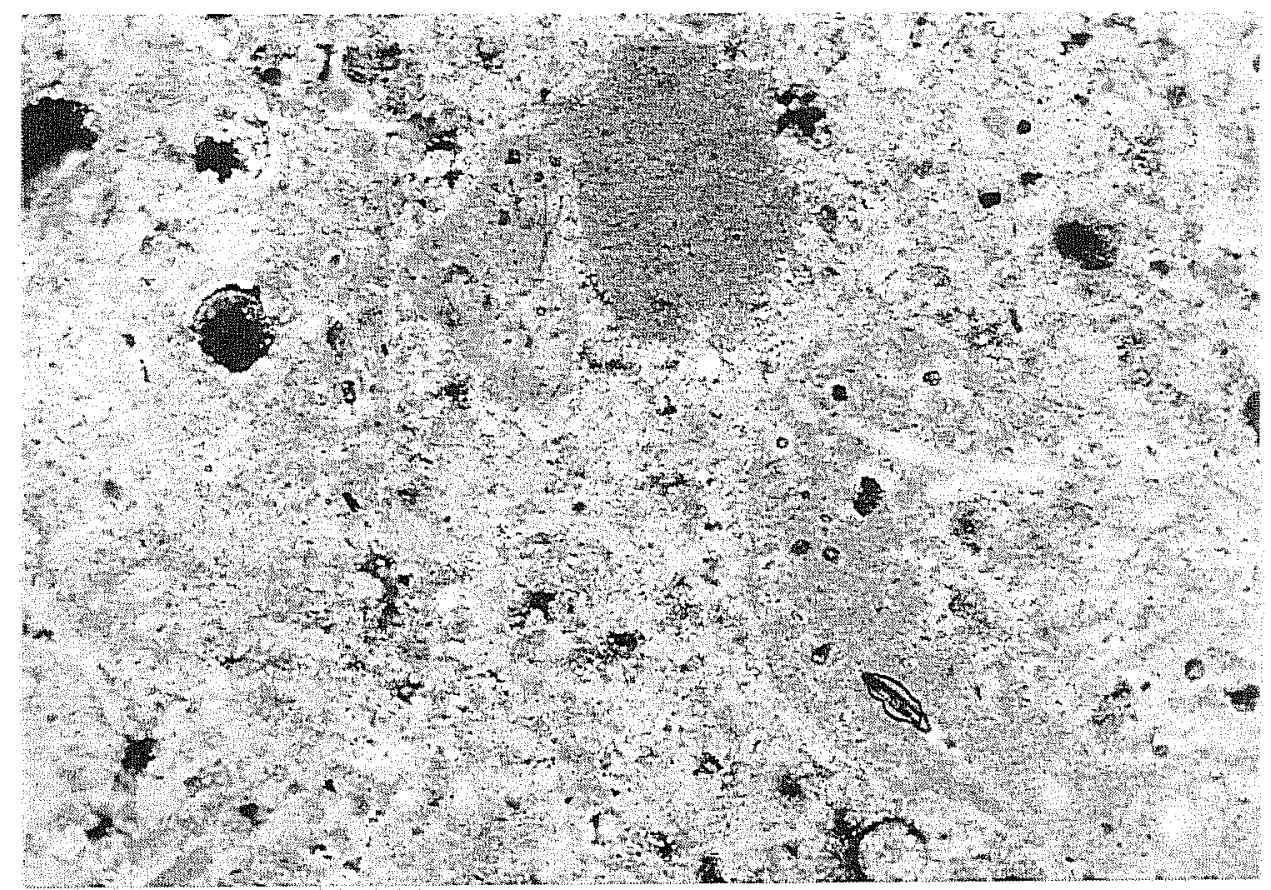

Figure A3. Detail of Figure A2, note calcined grain at top and micritic matrix.

\section{Group II - Samples from Exterior and Interior Sediments}

Sample Sed I (Exterior, from Unit 100N/93E): This comes from a depth of $24-33 \mathrm{~cm}$ below surface. In the field it consisted of poorly sorted dark brown (7.5YR4/2) mottled red brown clean sand and dark grey to black clayey domains. Locally are granulesize zones of clay and caliche, and some charcoal. The archaeological field notes depict this unit as brown clay loam with red landscape sand.

It is interesting that some of the components observed in this sample are similar to those found in the mortar. This includes numerous sand size grains of fine-grained limestone, many of which have been burnt. Also a few pisolite grains were noted. However this sample contains several components that were not found in the mortar. These include:

- Quartz sand - these occur normally as individual grains although a concentration of grains was noted in one part of the slide;

- Charcoal - these range in size from sand size pieces up to grains a few millimeters in diameter;

- Several grains of chert were observed. These range from rounded granular-size grains down to sand-size angular chips.

- A prominent component of this sample are pieces of fine grained calcium carbonate that have a porous or spongy fabric. One particularly large-grained fragment, over one centimeter across, strongly resembles tufa, and could indicate spring deposits nearby.

- Some grains appear to be pieces of mortar, somewhat similar to the sample described above. A prominent grain, several millimeters across, is composed of sand-size grains of micritic limestone in a fine matrix of burnt lime.

The matrix contains abundant finely comminuted silt size pieces and shreds of charcoal that have been worked into the groundmass. This homogenization could be related to either biological mixing of the material by soil fauna, or to human activities such as dumping, trampling or filling. 
Interpretation: This sample seems to be strongly influenced by human burning activities. This is indicated by the numerous calcined limestone clasts, pieces of charcoal, and the calcareous nature of the matrix, which is enriched in finely divided organic matter and some burnt lime. The heterogeneity of the material in addition to the poor sorting and lack of stratification suggest either dumping, trampling, or possibly postdepositional modification by soil fauna (see Figures A4-A6).

\section{Sample Sed-2 (Interior,}

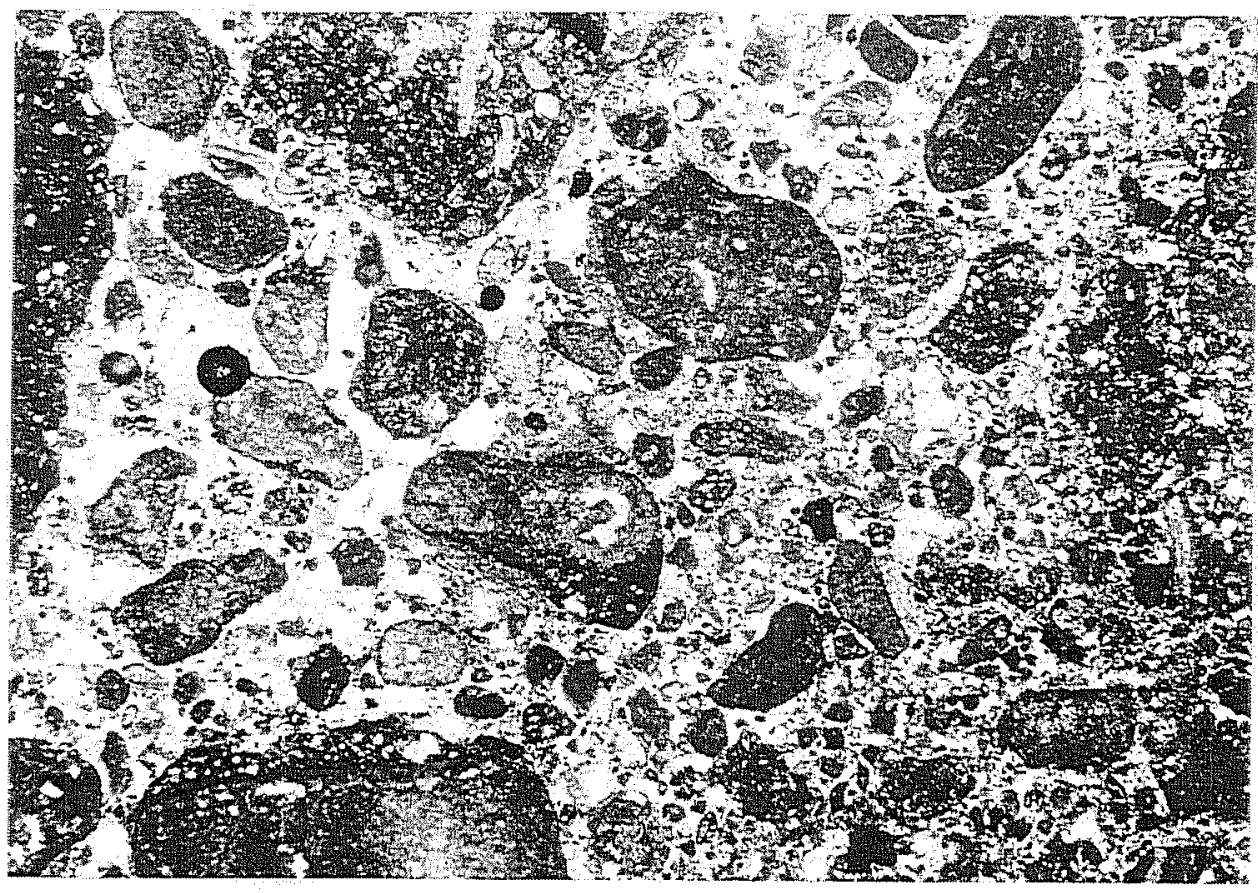

Figure A4. Micro-photographs of thin section of sediment sample from the facade of the Alamo. Note the loose aggregation of rounded, partially calcined micritic grains with quartz silt. A larger piece of angular biomicrite is at the top. Photographed in PL. from Unit 101N/96E): This

is a homogeneous, poorly sorted dark brown (7.5YR3/1) sandy to granular clay with inclusions of

quartz, limestone and possibly caliche. In the profile it is labeled as "medium grey-brown sandy clay," and this unit represents most of

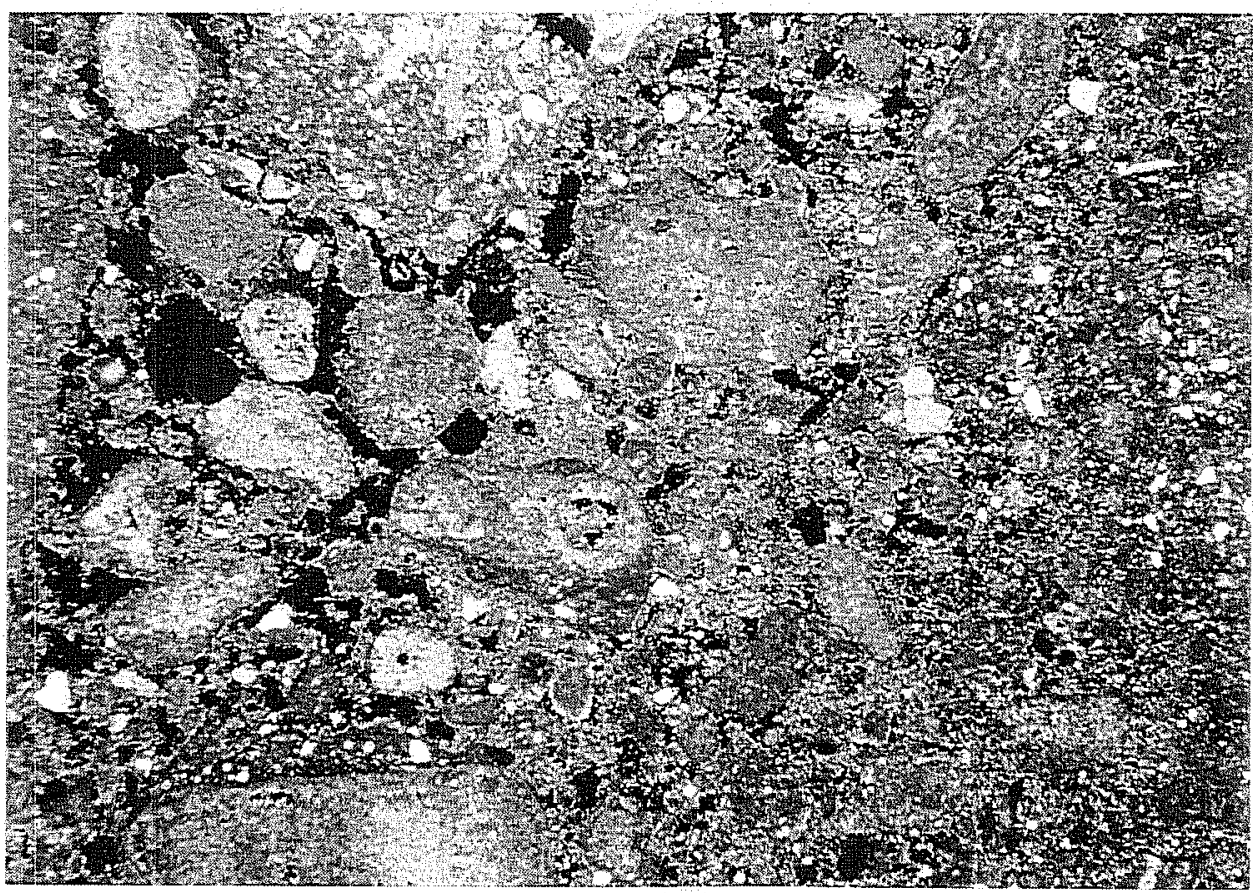
the sediment in the west profile. Local inclusions of chalk/plaster and brick were noted.

This sample strongly resembles sample SED-I, but is considerably richer in heavily calcined, sandsize microcrystalline limestone grains. In addition, the following were noted:

Figure A5. Same as Figure A4, photographed in CPL. The calcined nature of many of the calcareous clasts is clear in this view. 


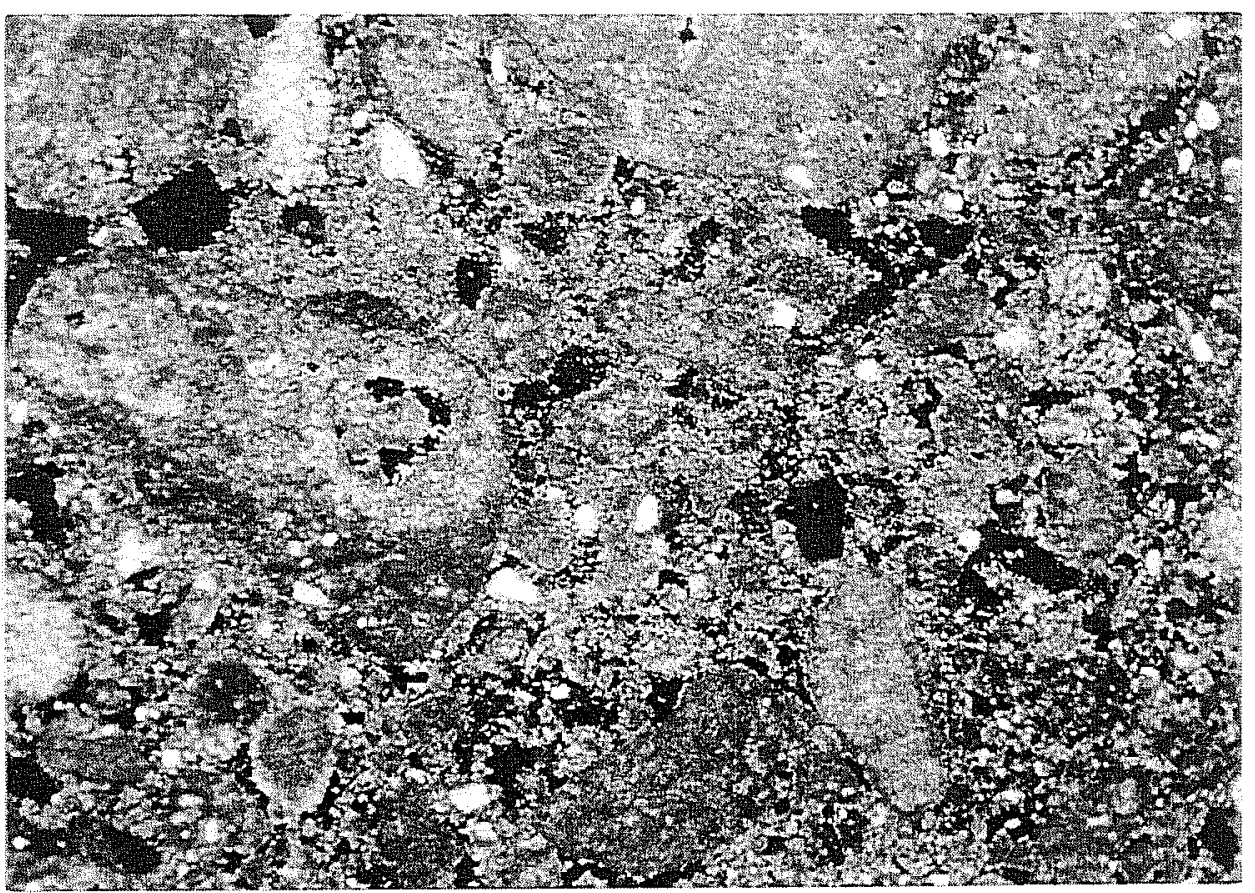

Figure A6. Detail of Figure A5, shows calcined nature of the clasts.

- A millimeter-size fragment of what appears to be prismatic calcite similar to that found in a stalagmite;

- Some pisolites were observed, although they are lower in abundance than in the mortar samples;

- This material has a very granular appearance in which the grains are loosely packed;

- Some aggregates occur, consisting of calcined limestone intimately mixed with burnt lime and quartz sand and silt;

- In contrast to sample SED-1 this sample has little if any charcoal, or fine-grained organic matter within the fine fraction.

Interpretation: This material mostly consists of fragments calcined limestone and lime, with only a minority of the never-heated, sand-size limestone grains. The absence of charcoal is somewhat surprising in this sample, in light of the abundance of calcined rock fragments. Overall, it seems this material constitutes the remains of some kind of intense burning activity. However, the material does not seem to have been close to the actual location of the fire because of the absence of charcoal or organic matter. 


\section{Glossary of Terms}

The following definitions are from American Geological Institute (1976).

Birefringence The property of splitting a beam of ordinary light into two beams which transverse a crystal at different speeds. Possessed by crystals belonging to crystallographic system other than the isometric.

Massive Of homogenous structure.

Micritic $\quad$ Relating to micrite, a limestone with a very fine texture.

Pisolite A spherical or subspherical body with concentrically laminated accretions, greater than $2 \mathrm{~mm}$ in diameter.

Porphyritic Relating to a mixture of larger crystals or grains in a fine-textured matrix.

Rhomb A rhomboid-shaped crystal.

\section{References Cited}

American Geological Institute

1976 Dictionary of Geological Terms. Anchor, Garden City, New York.

Bullock, P., N. Fedoroff, A. Jongerius, G. Stoops, and T. Tursina

1985 Handbook For Soil Thin Section Description. Waine Research, Wolverhampton.

Courty, M. A., P. Goldberg, and R. 1. Macphail

1989 Soils and Micromorphology in Archaeology. Cambridge University Press, Cambridge. 
The matrix, in which these grains occur in a porphyricrelated distribution, is composed of predominantly silt-size pieces of fine micritic calcite. Many of these also appear to have been heated and calcined. It seems that many of these grains have been recrystallized, and as a result it is not possible to observe any individual rhombs of ash crystals which, on a superficial level, this matrix material resembles.

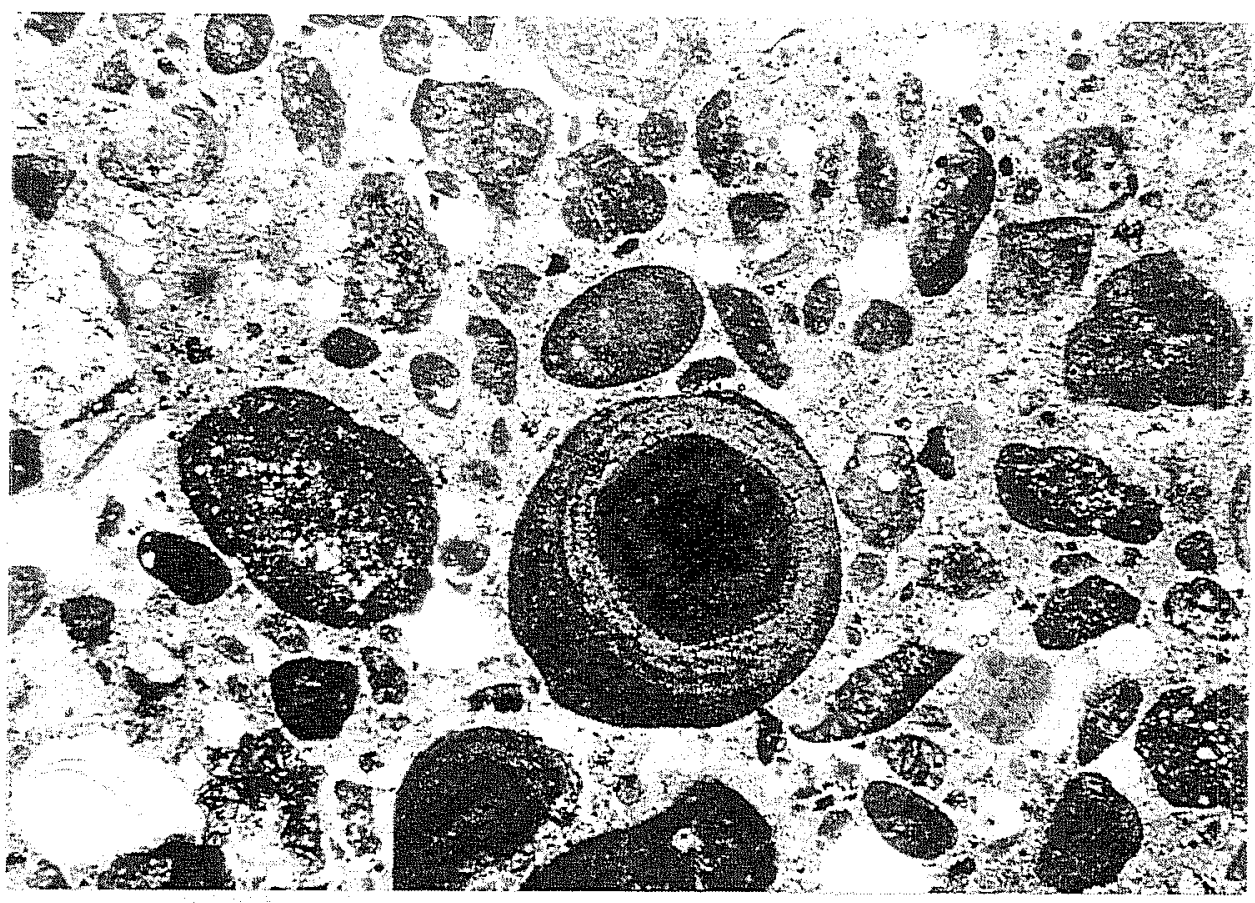

Interpretation: This mortar appears to be composed of sand- and granule-sized material, whose uniformity in size (sorting) and shape (well-rounded) suggest that is derived from a relatively high energy source such a stream. It is not clear exactly where or which stream system served as the source, since during

sampling there was no time to conduct a survey of the area. The San Antonio River nearby is not an unreasonable first place to look. The finer-grained matrix is essentially composed of burned lime into

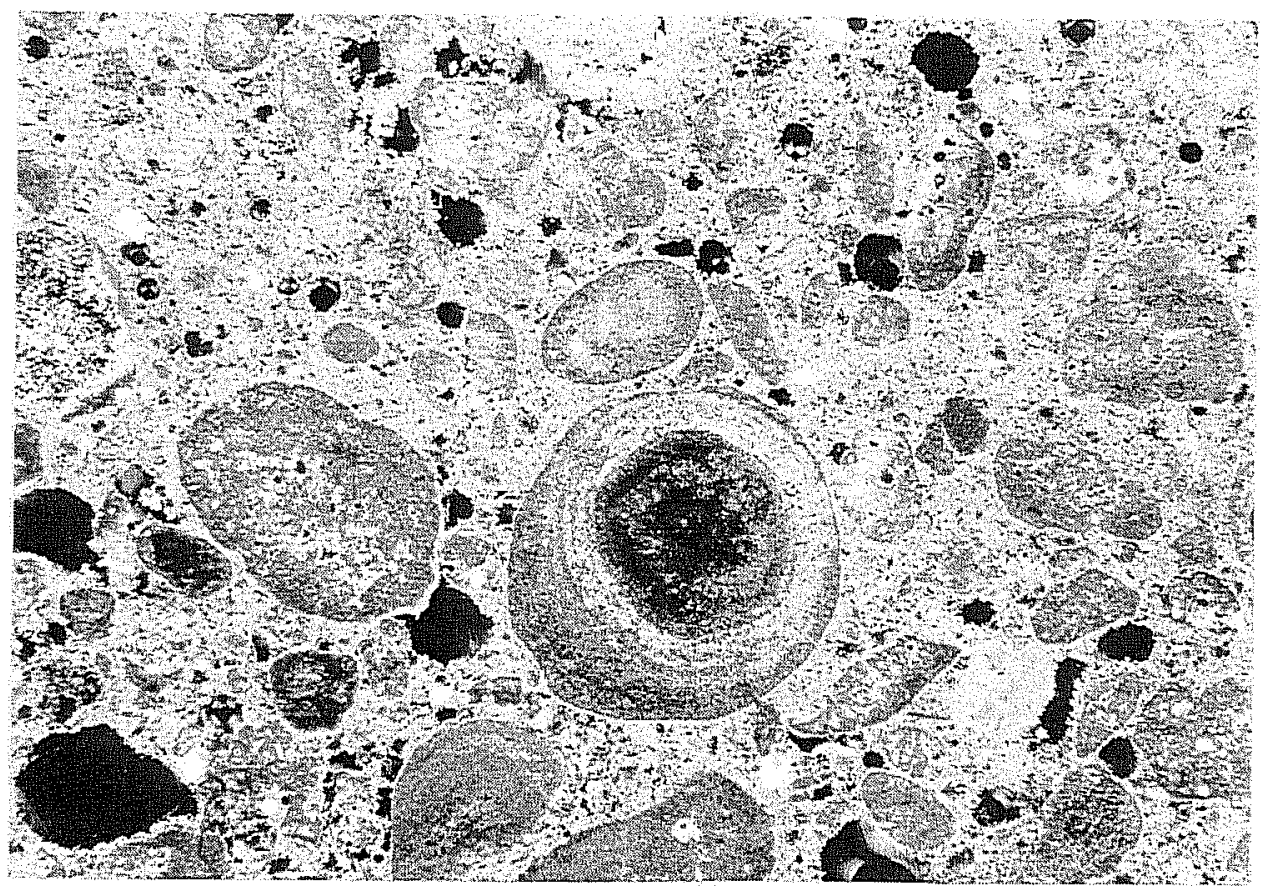
which was mixed the sandy and fine granular material. The fact that some of the sand-size micrite grains were altered by heating suggests the possibility that this material served as a source for the lime (Figures A1-A3).

Figure A2. Same as Figure A1, photographed in CPL. Note the birefringence of the matrix, indicative of calcium carbonate. 


\section{Appendix A \\ Micromorphological Analysis of Selected Samples from the Alamo}

\section{Paul Goldberg Boston University}

$I^{2}$ n January 1995, a number of samples were collected during the excavations at the Alamo south transept by staff from the Center for Archaeological Research of The University of Texas at San Antonio. One sample was obtained from the east wall of Unit $100 \mathrm{~N} / 93 \mathrm{E}$ in the exterior excavations, a second from the west wall of Unit 101N95E in the interior excavations. Two samples of the original mortar were also taken, from above the entrance to the church and at the upper reconstructed southwest corner. The samples were analyzed using the technique of micromorphology, the study of undisturbed soils, sediments, and other archaeological materials (e.g. ceramics, bricks, mortars) at a microscopic scale. Micromorphology studies intact, oriented samples in which the original components and their geometrical relationships are conserved.

Micromorphological analysis allows for the observation of composition (mineral and organic), texture (size, sorting), and most important, fabric-the geometric relationships among the constituents. Within an individual thin section it is possible to observe microstratigraphic sequences that reflect temporal changes in depositional and post-depositional processes, as for example, sedimentation followed by bioturbation and then clay translocation.

Samples were collected as whole, undisturbed blocks which were removed from the exposed profiles and carefully wrapped in tissue paper and secured tightly with tape. The samples were shipped to Spectrum Petrographics, Oregon, where they were embedded in epoxy resin. From the hardened blocks both $2-x-3-$ inch and $23-x-46-\mathrm{mm}$ thin sections were prepared. The thin sections were examined with a petrographic microscope under plane polarized (PL) and crosspolarized light (XPL), at magnifications ranging from $20 \mathrm{x}$ to $200 \mathrm{x}$. Observations were noted using the descriptive terminology of Bullock et al. (1985) and Courty et al. (1989). A glossary of terms is provided at the end of this report.

\section{Group I - Mortar Samples}

As both samples of mortar are identical, they are described together. The samples are comprised of well-rounded grains of carbonate ranging in size from medium sand to granules four to five millimeters across. Most of these grains are well rounded, although a few are more angular. Whereas most appear to be composed of massive fine-grained micritic limestone, several are in fact pisolites, which show concentric layering around a micritic core. Many of these grains have been heated, as shown by a reduction in birefringence, although these heated grains constitute only a very small proportion of the grains present. 


\section{Appendix B \\ Human Osteological Material}

The human osteological remains recovered during this project were identified by Dr. Karin Wiltschke, The National Museum of Austria, Vienna. In addition to Wiltschke's assistance, Hillson (1986) and White (1991) were used as a references.
Twenty definite human and four possible human bones were recovered (Table B1), most (80.0 percent) of which were in fragmentary condition. All were small in size, isolated, disarticulated, and scattered throughout approximately $40 \mathrm{~cm}$ depth, over 11 square meters, or approximately $4.4 \mathrm{~m}^{3}$ of matrix, in the interior excavations.

\section{References Cited}

Hillson, S.

1986 Teeth. Cambridge University Press, Cambridge.

White, T. D.

1991 Human Osteology. Academic, New York. 
Table B1. Human Osteological Material Recovered from Interior Excavations

\begin{tabular}{|c|c|c|c|}
\hline Provenience & $\begin{array}{c}\text { Level } \\
\text { (cm BD) }\end{array}$ & Element & Notes \\
\hline $101 \mathrm{~N} / 93 \mathrm{E}$ & Surf. to 104 & Cranium (2) fragments & 1 stained with tar \\
\hline $101 \mathrm{~N} / 95 \mathrm{E}$ & $114-124$ & Possible vertebra fragments (2) & \\
\hline \multirow[t]{3}{*}{$101 \mathrm{~N} / 96 \mathrm{E}$} & $104-124$ & Occipital fragment & Stained with tar \\
\hline & $104-143$ & Left first phalange (foot) & Proximal end broken \\
\hline & & Permanent lower right central incisor & $\begin{array}{l}\text { Exihibits slight dental hypoplasia. Exhibits } \\
\text { considerable accumulation of dental calculus. }\end{array}$ \\
\hline \multirow[t]{2}{*}{$101 \mathrm{~N} / 97 \mathrm{E}$} & 104-124 & Metatarsal fragment & Diaphysis \\
\hline & $104-143$ & Permanent upper left central incisor & $\begin{array}{l}\text { Exihibits severe dental hypoplasia, recording at } \\
\text { least two instances between the ages of } 1 \text { and } 3 \\
\text { of serious stress due to illness and/or starvation } \\
\text { (Hillson 1986:135). Exhibits considerable } \\
\text { accumulation of dental calculus }\end{array}$ \\
\hline \multirow[t]{2}{*}{$101 \mathrm{~N} / 98 \mathrm{E}$} & \multirow[t]{2}{*}{$104-143$} & $\begin{array}{l}\text { Permanent upper left lateral incisor } \\
\text { fragment }\end{array}$ & $\begin{array}{l}\text { Occlusal } 1 / 2 \text { and entire lingual surface are } \\
\text { missing. Exhibits vertical lines of hypoplasia and } \\
\text { some dental calculus accumulation }\end{array}$ \\
\hline & & Metatarsal fragment & Distal 1/2 \\
\hline $101 \mathrm{~N} / 99 \mathrm{E}$ & 104-143 & Parietal fragment & \\
\hline $102 \mathrm{~N} / 93 \mathrm{E}$ & $104-143$ & Right first phalange (foot) & \\
\hline $102 \mathrm{~N} / 95 \mathrm{E}$ & 104-143 & Right third phalange (foot) & \\
\hline \multirow[t]{3}{*}{$102 \mathrm{~N} / 96 \mathrm{E}$} & \multirow[t]{3}{*}{$104-143$} & Right lateral cuneiform fragment & Dorsal 2/3 \\
\hline & & Left second phalange (foot) fragment & Distal 2/3 \\
\hline & & Possible rib fragment & \\
\hline \multirow[t]{3}{*}{$102 \mathrm{~N} / 97 \mathrm{E}$} & \multirow[t]{3}{*}{$104-143$} & Left first phalange (foot) & \\
\hline & & Possible proximal metatarsal fragment & Proximal 1/4 \\
\hline & & Metatarsal & Proximal 3/4 \\
\hline \multirow[t]{5}{*}{$102 \mathrm{~N} / 98 \mathrm{E}$} & \multirow[t]{5}{*}{$104-143$} & Right third phalange (foot) fragment & Distal 3/4 \\
\hline & & Right third phalange (hand) & \\
\hline & & Possible rib fragment & \\
\hline & & Left first phalange (foot) & Distal $1 / 2$ \\
\hline & & Right navicular fragment & Medial 1/2 \\
\hline
\end{tabular}


Appendix C

Complete Provenienced Artifact Tables 


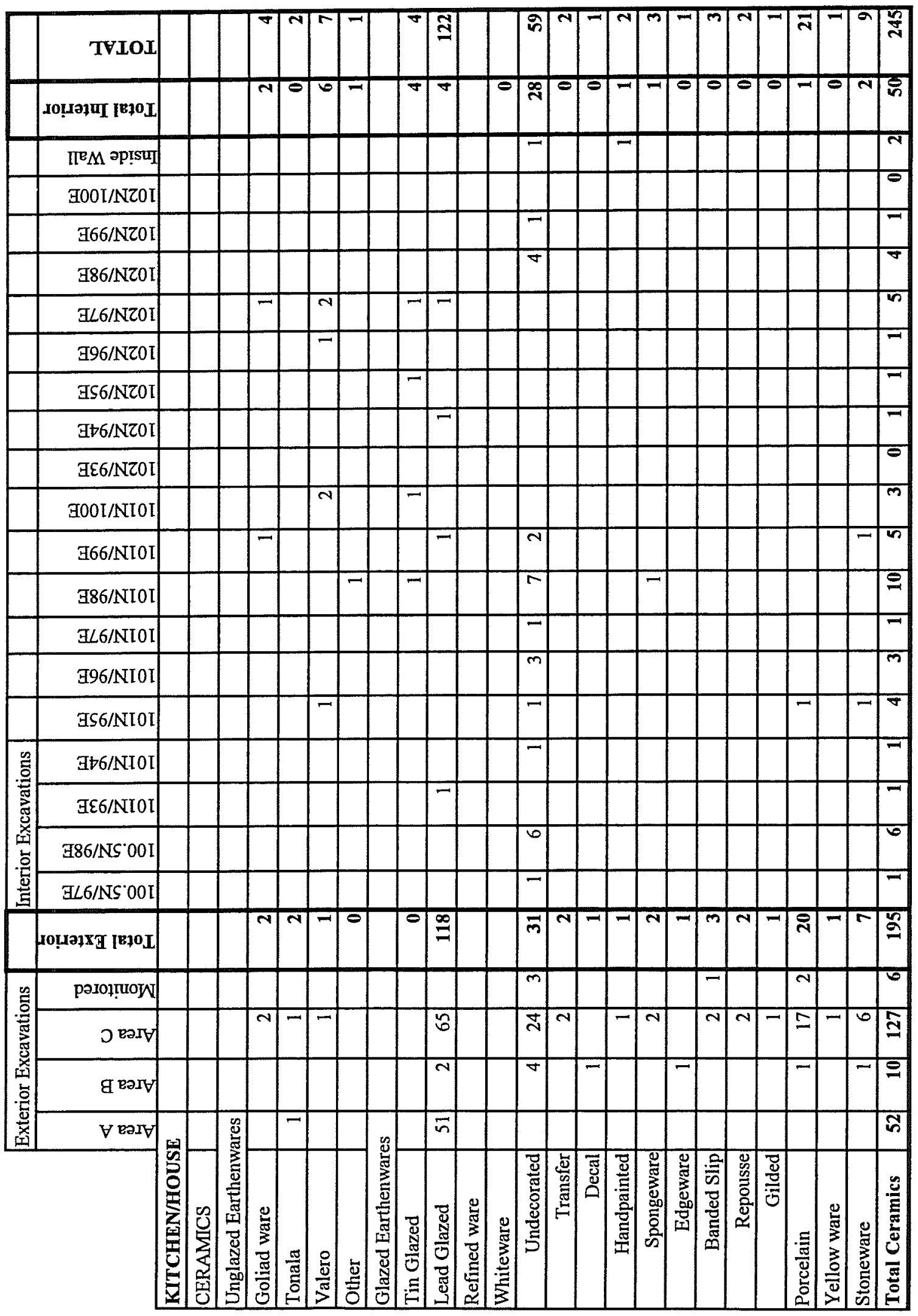




\begin{tabular}{|c|c|c|c|c|c|c|c|c|c|c|c|c|c|c|c|c|c|c|c|c|c|c|c|}
\hline & TYIOI & $\overline{\text {; }}$ & \begin{tabular}{l|l}
0 \\
\end{tabular} & & ป & $\overline{6}$ & 7 & 7 & ले & ता & $\underset{\mathbf{N}}{\mathbf{N}}$ & m) & 7 & & $\underline{\theta}$ & णा & 苛 & & & का & $\Rightarrow$ & $\theta$ & \\
\hline & 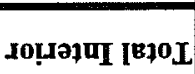 & & त्र & हे & 당 & চ⿵ & 0 & $\Rightarrow$ & $\cong$ & 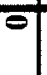 & 勇 & 0 & 0 & - & $\infty$ & ता & 응 & 0 & $\theta$ & ल & 0 & e & m \\
\hline & IIE $\mathbb{E}_{M}$ әpIsu & & & $\bar{\Xi}$ & & & & & & & $=$ & & & & & & m & & & & & & - \\
\hline & BOHOL/NZOI & $n$ & n]s & 6 & ता & 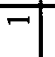 & & & & & \pm & & & & & & \pm & & & $=$ & & & -7 \\
\hline & $\exists 66 / \mathrm{NZOI}$ & $m$ & m/ & m & $m$ & & & & & & a) & & & & & & 요 & & & & & & 이 \\
\hline & ㅍ86/NZ0I & \pm & \pm 5 & 6) & $\infty$ & & & & & & ली & & & & & & 용 & & & & & & 0 \\
\hline & $\exists \angle 6 / \mathrm{NZOI}$ & $n$ & n? & 2 & n & 7 & & & & & 이 & & & & & & $\bar{m}$ & & & & & & 0 \\
\hline & 396/NZ0I & & $\sqrt{4 / 2}$ & 8 & N & 7 & & & & & $a$ & & & & & & 의 & & & & & & 0 \\
\hline & $356 / N Z 0 I$ & & $\begin{array}{c}7 \\
\end{array}$ & ता & 寸 & -1 & & & & & $=$ & & & & & & I & & & & & & 0 \\
\hline & $\exists \triangleright 6 / \mathrm{NZOI}$ & & 77 & $\bar{z}$ & & -7 & & & -1 & & $\nabla$ & & & & & & $n$ & & & & & & 0 \\
\hline & تE $6 / \mathrm{NZ} 0 \mathrm{I}$ & & n'o & ता & $m$ & & & & & & 이 & & & & & & 9 & & & & & & 0 \\
\hline & Fn0I/NIOI & & बा4 & 010 & $\infty$ & $\bar{\nabla}$ & & & & & ㄱ. & & & & & & हి & & & & & & 0 \\
\hline & J66/NTOI & & $\bar{a}$ & 8 & - & $n$ & & & & & $n$ & & & & & & 8 & & & - & & & -7 \\
\hline & Fa & & 6: & n: & $\Xi$ & $\nabla$ & & & $=$ & & J & & & & ल & & $\overline{6}$ & & & & & & 0 \\
\hline & TU COTIOT & & 2) & $\infty$ & $\nabla$ & 10 & & & $\nabla$ & & 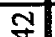 & & & & 6 & 4 & $\bar{n}$ & & & & & & 인 \\
\hline & TR & & ब10 & $\infty$ & m & $\nabla$ & & & & & 沗 & & & & & & 기 & & & & & & 0 \\
\hline & & & el= & $\nabla$ & $\nabla$ & ता & & & 6 & & 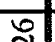 & & & & & & 용 & & & -1 & & & $\Rightarrow$ \\
\hline & & & & & & & & & & & & & & & & & & & & & & & \\
\hline$\Xi$ & Jt6/NI0I & & $=4$ & $n$ & 0 & & & & & & i & & & & & & స1 & & & & & & 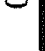 \\
\hline 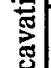 & घEG/NLOI & & बा० & ब & $n$ & $n$ & & & 7 & & ন & & & & & & Бి & & & & & & 0 \\
\hline $\begin{array}{l}x \\
\text { 部 }\end{array}$ & A86/NS $00 \mathrm{~L}$ & & त्र & r & aा & -1 & & & -7 & & 㐫 & & & & & & $\overline{7}$ & & & & & & 0 \\
\hline$\stackrel{5}{5}$ & $\exists \angle 6 / \mathrm{N}^{\circ} 00 \mathrm{I}$ & & E & & $\infty$ & & & & - & & 9 & & & & & & สิ & & & & & & 0 \\
\hline & 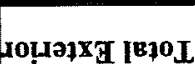 & & $2 \%$ & $\infty$ & फी & ज़ & -7 & -7 & & 4 & 독 & mा & $=$ & $\pi$ & 4 & 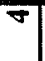 & $\bar{~} \bar{\not}$ & & & ता & $\pi$ & $\theta$ & $m$ \\
\hline \multirow{5}{*}{ 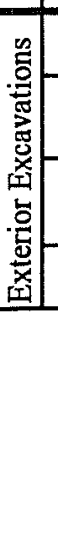 } & paro!̣uow & & הা: & $\Xi$ & -7 & & & & $\infty$ & & A & & & & $\pi$ & & สิ & & & & & & 아 \\
\hline & Ј вәгy & & 8 & $\bar{q}$ & $\vec{m}$ & สิ & 7 & -7 & 0 & ता & $\frac{\nabla}{\sim}$ & $m$ & $=$ & 4 & $\overline{-}$ & N| & Б్ & & & & & & 0 \\
\hline & g e्rF & & $\pi$ & ন্য & $m$ & $m$ & & & 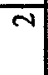 & & in & & & & & ता & $\bar{\sigma}$ & \multirow{3}{*}{ 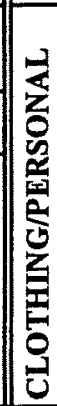 } & \multirow{3}{*}{ 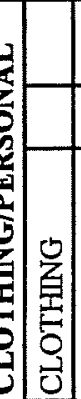 } & ता & $=$ & & $m$ \\
\hline & $\forall$ ЕәГ $\forall$ & & $\overline{-}$ & $=$ & & & & & & & $\pi$ & & & & & & ज & & & & & & 0 \\
\hline & & $\begin{array}{l}0 \\
\frac{0}{0} \\
0\end{array}$ & 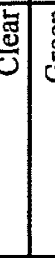 & 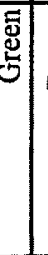 & 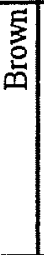 & 产 & $\begin{array}{l}\text { 䍖 } \\
\end{array}$ & 总 & 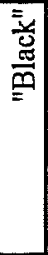 & 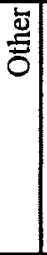 & 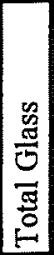 & $\begin{array}{l}0 \\
0 \\
0 \\
0 \\
0 \\
\overline{0} \\
0 \\
0\end{array}$ & 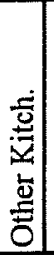 & 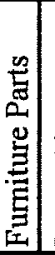 & 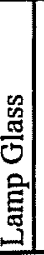 & 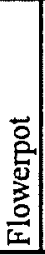 & 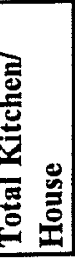 & & & 告 & 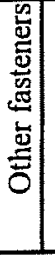 & 韋 & 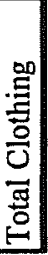 \\
\hline
\end{tabular}




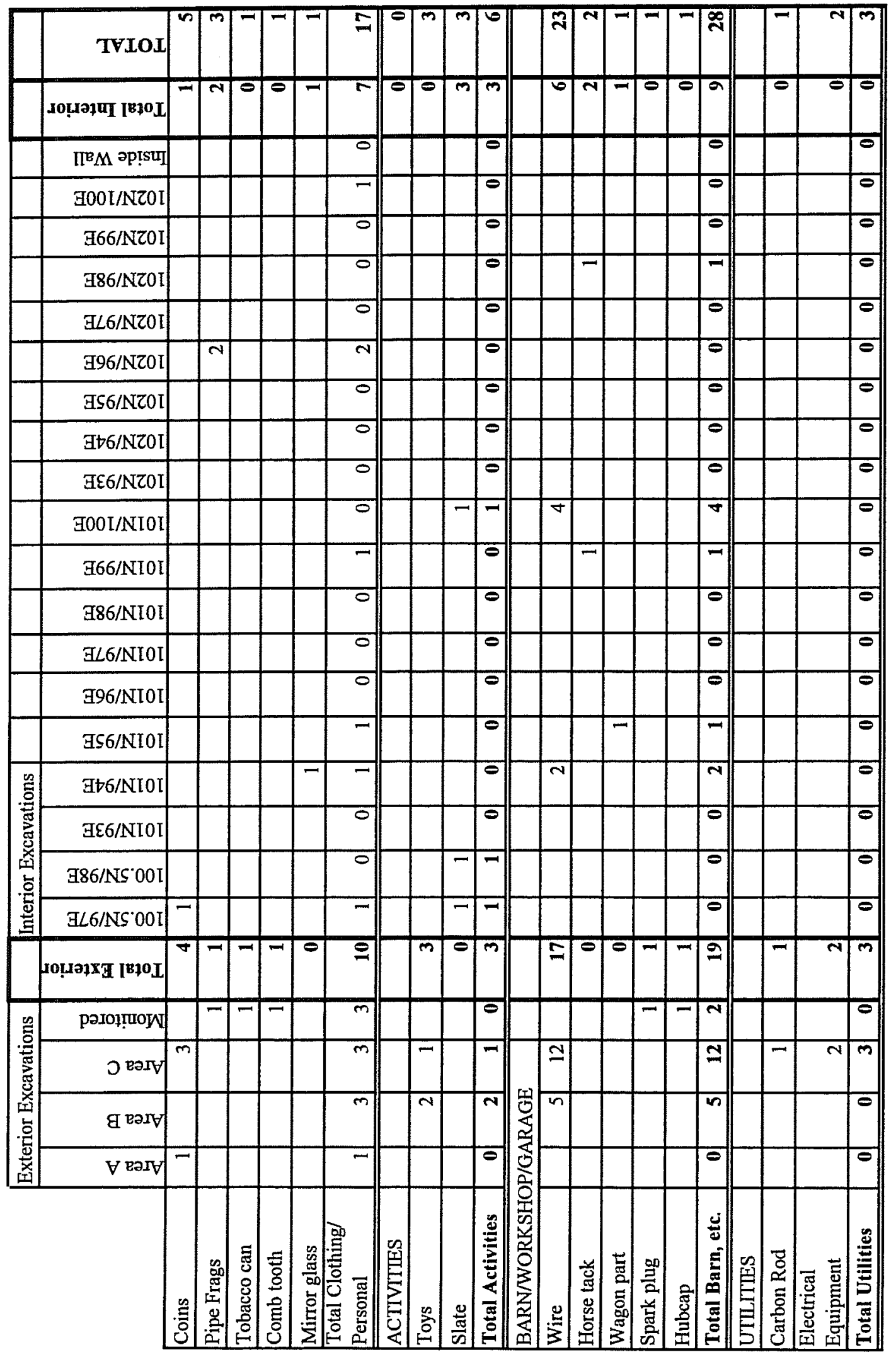




\begin{tabular}{|c|c|c|c|c|c|c|c|c|c|c|c|c|c|c|c|c|c|c|c|c|c|c|}
\hline & TVIOI & & \begin{tabular}{|l|}
\multirow{3}{*}{} \\
\end{tabular} & 5 & $\mathscr{g}$ & $\bar{\sigma}$ & 7 & -7 & $N$ & $\Xi$ & 7 & 9 & 익 & 4 & 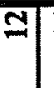 & $\nabla$ & $\frac{\nabla}{2}$ & 2 & 97 & 임 & $\begin{array}{l}\bar{\sigma} \\
\Xi\end{array}$ & 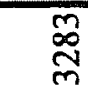 \\
\hline & - & & ल] & 8 & 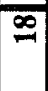 & $\theta$ & $\circ$ & $\theta$ & $\theta$ & $m$ & वा & ला & $\infty$ & of & - & m: & $\widehat{\overparen{్}}$ & $m$ & 10 & m & $\begin{array}{l}\bar{\beth} \\
\beth\end{array}$ & 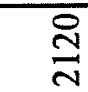 \\
\hline & II $_{M} M$ әр!su & & & & & & & & & & & & & & & & $\theta$ & & & $\theta$ & 의 & 9 \\
\hline & J00L/NZOI & & & & & & & & & & & & & & & & $\Rightarrow$ & & & $\theta$ & $=$ & $\stackrel{\sim}{6}$ \\
\hline & 366/NZ0I & & & & & & & & & & & & & & & & $\theta$ & & & 0 & $n$ & $\cong$ \\
\hline & G86/NZ0I & & & $\approx$ & त) & & & & & & & & & & & T: & 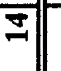 & & & $\theta$ & 예 & $\bar{\Xi}$ \\
\hline & GL6/NZ0I & & $\infty$ & $m$ & & & & & & & & & & & & & $\exists$ & & & 0 & in & 2 \\
\hline & B96/NZ0I & & $\nabla$ & $n$ & & & & & & & & & & & & & न] & & & 0 & ज़ & $n$ \\
\hline & BS6/NZOI & & & $m$ & & & & & & & & & & & & & $m$ & & & $\theta$ & (స) & $\hat{a}$ \\
\hline & $\mathrm{Bt} 6 / \mathrm{NZOI}$ & & & a & & & & & & & & & -1 & & & & 9 & & & $\theta$ & $\approx$ & 웅 \\
\hline & BE6/NZOI & & & N & & & & & & & & & 6 & & & & $\infty$ & & & $\theta$ & $m$ & $\overline{2}$ \\
\hline & J00L/NIOI & & $\stackrel{\infty}{-\infty}$ & $\bar{N}$ & $\cong$ & & & & & & & & & & N & & ถั & & & 0 & $\infty$ & $\mathbb{I}$ \\
\hline & $\exists 66 /$ NI0I & & $\because$ & $\bar{m}$ & N & & & & & ता & & & & & & & ติ) & & & क) & 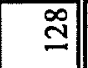 & 옥 \\
\hline & B86/NLOI & & 요 & $\equiv$ & & & & & & & & & -1 & & & 7 & ले & $\bar{N}$ & & $\mathrm{~N}$ & $\infty$ & $\stackrel{\infty}{1}$ \\
\hline & ב $\angle 6 /$ NIOI & & 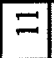 & $\nabla$ & & & & & & & & & & & & & 9 & & & 0 & $\infty$ & $\Phi$ \\
\hline & 396/NI0I & & \pm & 9 & & & & & & -7 & & & & & $m$ & & $\bar{m}$ & & & $\theta$ & $\overline{\mathrm{N}}$ & $\underset{\sim}{\infty}$ \\
\hline & ヨS6/NIOI & & ता & & & & & & & & & & & & & & $\pi$ & & & $\theta$ & 2 & ปิ \\
\hline घี & 3t6/NI0I & & $\nabla$ & $n$ & & & & & & & & $m$ & & & & $-7 !$ & 2 & & & 0 & $\infty$ & $\Xi$ \\
\hline 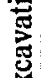 & GE6/NIOL & & ता & $\infty$ & & & & & & & & & & & - & & $\exists$ & & & 이 & $\mathbb{2}$ & $\underline{m}$ \\
\hline 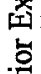 & A86/NS $00 \mathrm{I}$ & & m. & 요 & - & & & & & & & & & & & & J & $=$ & & -7 & $\approx$ & $\tilde{n}$ \\
\hline 홀 & 亚6/NS $00 \mathrm{I}$ & & $=$ & 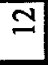 & - & & & & & & & & & & & & $\mathbb{N}$ & & & $\theta$ & $m$ & in \\
\hline & 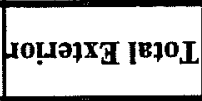 & & $\stackrel{p}{m}$ & 5 & $\infty$ & $=$ & - & 7 & $\pi$ & \pm & -1 & ण & N & ता & 6 & $\exists$ & $\overline{8}$ & I & 7 & $m$ & : & $\stackrel{3}{\varrho}$ \\
\hline$\stackrel{2}{0}$ & pəron!̣ow & & & & & & & & & & & & & & & & 0 & & & 0 & & से \\
\hline 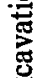 & ว שary & & $\stackrel{2}{\Xi}$ & $m$ & $\overline{6}$ & - & - & & -7 & 인 & & 0 & & N & $m$ & $=$ & $\widehat{స}$ & $r$ & - & $|\infty|$ & $\stackrel{\infty}{=}$ & $\hat{\varnothing}_{\infty}$ \\
\hline 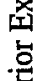 & q еәл & & 7 & m & iי & & & 7 & - & $\nabla$ & - & & $\sim$ & & $m$ & & F & n & & $n$ & $\stackrel{9}{\rho}$ & 号 \\
\hline $\begin{array}{r}\overline{\vec{x}} \\
\text { 至 }\end{array}$ & $\mathrm{V}$ вər & & & $\pi$ & & & & & & & & & & & & & N) & & & $\theta$ & 2 & 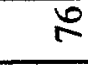 \\
\hline & & 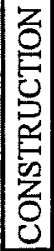 & $\mid \begin{array}{l}0 \\
0 \\
0 \\
0 \\
3 \\
0 \\
0 \\
3 \\
3 \\
3\end{array}$ & 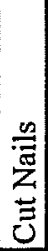 & 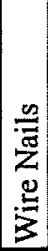 & 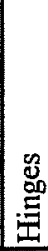 & $\frac{n}{\overline{0}}$ & $\begin{array}{l}\frac{n}{2} \\
\frac{2}{5} \\
\frac{5}{2} \\
3 \\
3\end{array}$ & 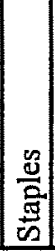 & 总 & $\stackrel{\oplus}{\Xi}$ & $\begin{array}{l}\text { t: } \\
\text { 닝 } \\
\end{array}$ & $\frac{\frac{w}{v}}{\frac{a}{a}}$ & $\begin{array}{l}\frac{0}{0} \\
0 \\
0 \\
0 \\
0\end{array}$ & 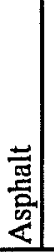 & $\stackrel{\vec{s}}{\tilde{\Xi}}$ & 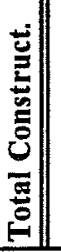 & 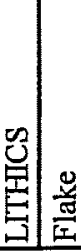 & 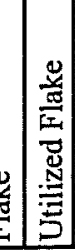 & 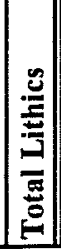 & 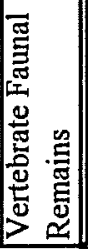 & 党点 \\
\hline
\end{tabular}


4 